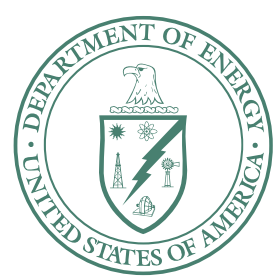

U.S. Department of Energy

Idaho Operations Office

\title{
Operable Unit 3-13, Group 3, Other Surface Soils (Phase I) Remedial Action Report
}

July 2007 
DOE/ID-11311

Revision 0

Project No. 23083

\section{Operable Unit 3-13, Group 3, Other Surface Soils (Phase I) Remedial Action Report}

July 2007

Prepared for the 



\begin{abstract}
This Remedial Action Report summarizes activities undertaken to remediate the Operable Unit 3-13, Group 3, Other Surface Soils, Phase I sites at the Idaho Nuclear Technology and Engineering Center at the Idaho National Laboratory Site. The 10 sites addressed in this report were defined in the Operable Unit 3-13 Record of Decision and subsequent implementing documents. This report concludes that remediation requirements and cleanup goals established for these 10 sites have been accomplished and are hereafter considered No Action or No Further Action sites.
\end{abstract}




\section{CONTENTS}

ABSTRACT

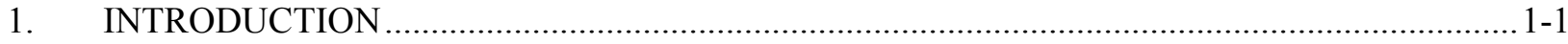

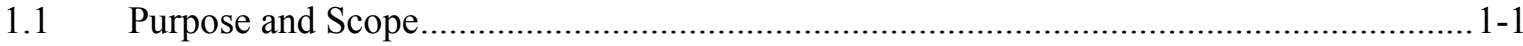

1.2 Organization of the Remedial Action Report ............................................................ 1-1

1.3 Site Description and Background of the Idaho National Laboratory Site ........................ 1-2

1.4 Background of INTEC and WAG 3 Operable Units ................................................ 1-4

1.4.1 INTEC Site Location and Description ..................................................... 1-4

1.4.2 Operations and Waste Management Practices that Contributed to

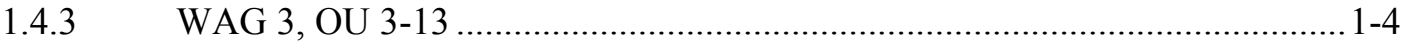

1.4.4 Identification of Phase I, Group 3, Sites ..................................................... 1-5

1.5 Remediation Goals for OU 3-13, Group 3, Other Surface Soils .................................... 1-5

2. SITE CPP-03, TEMPORARY STORAGE AREA SOUTHEAST OF CPP-603........................2-1

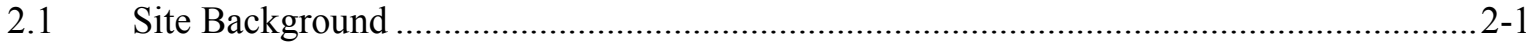

2.1.1 Site CPP-03 Location and Description...................................................... 2-1

2.1.2 Operations and Waste Management Practices that Contributed to Contamination at Site CPP-03..................................................................... 2-1

2.1.3 Summary of CPP-03 Remedial Design ...................................................... 2-5

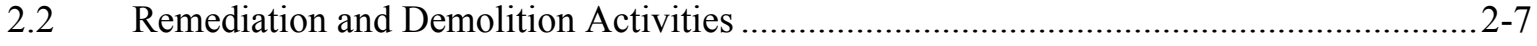

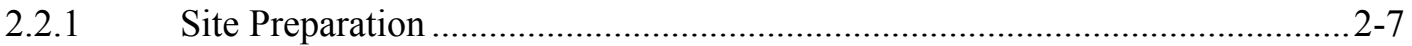

2.2.2 Contaminated Soil Excavation and Disposal .............................................. 2-8

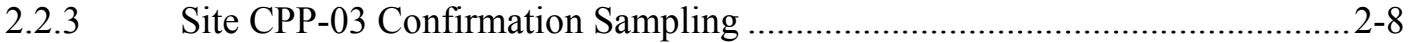

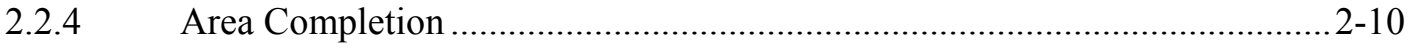

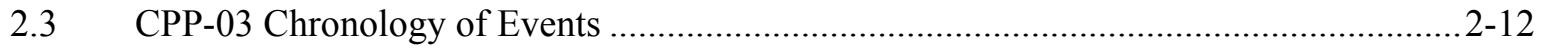

$2.4 \quad$ Performance Standards and Construction Quality Control ..........................................2-12

2.5 CPP-03 Final Inspection and Certification........................................................ 2-12

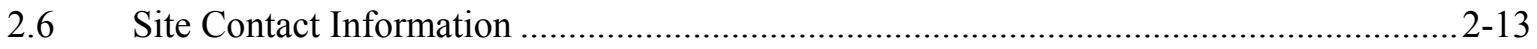


3. CPP-34A/34B, SOIL STORAGE AREAS (DISPOSAL TRENCHES) IN NORTHEAST

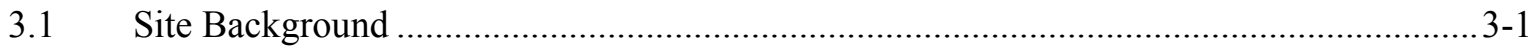

3.1.1 Summary of Remedial Design ........................................................... $3-1$

3.2 Remediation and Demolition Activities .................................................................. 3-2

3.2.1 Site Mobilization and Infrastructure Establishment...................................... 3-2

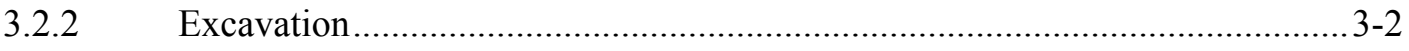

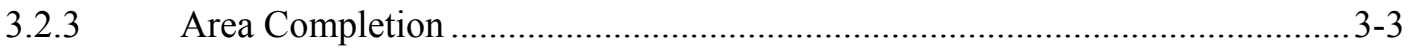

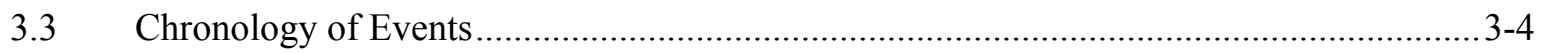

3.4 Performance Standards and Construction Quality Control ............................................ 3-5

3.4.1 Sampling Activities and Results ......................................................... 3-5

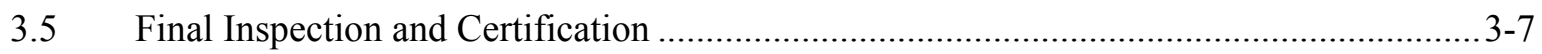

3.6 Site Contact Information …...............................................................................

4. CPP-37A, GRAVEL PIT OUTSIDE INTEC FENCE ….............................................................

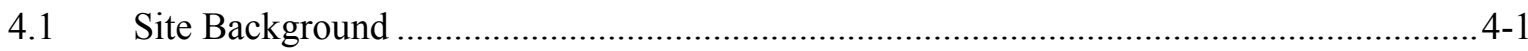

4.1.1 Summary of Remedial Design ........................................................... $4-1$

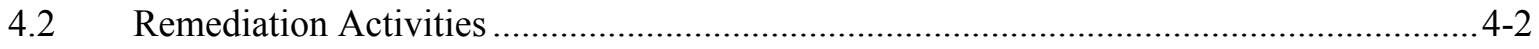

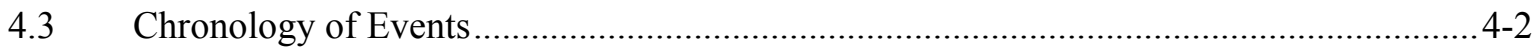

5. CPP-37B, GRAVEL PIT AND DEBRIS LANDFILL INSIDE INTEC FENCE ........................5-1

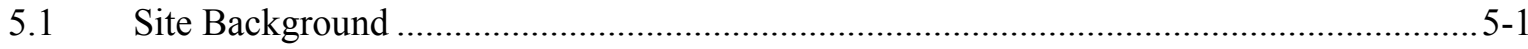

5.1.1 Summary of Remedial Design ......................................................... $5-1$

5.2 Remediation and Demolition Activities .................................................................... 5-2

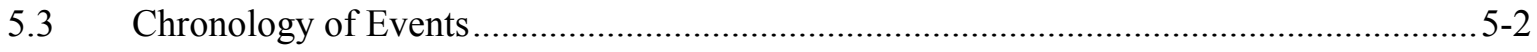

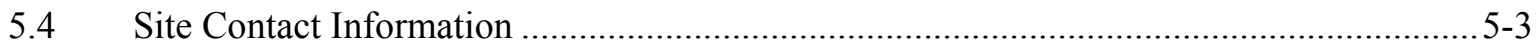

6. CPP-37C, NEW SITE CONTAMINATION AREA SOUTHWEST OF CPP-37B .....................6-1

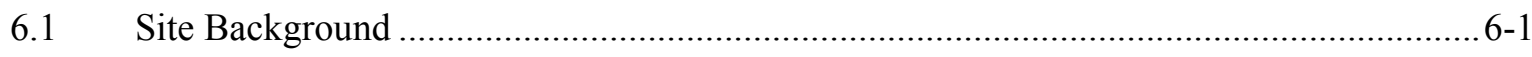

6.1.1 Summary of Remedial Design ............................................................. 6-1

6.2 Remediation and Demolition Activities ............................................................... 6-1 


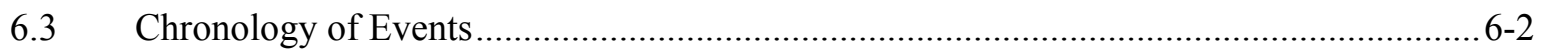

Site Contact Information ..................................................................................... $6-2$

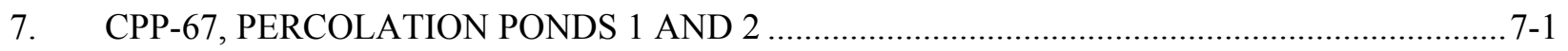

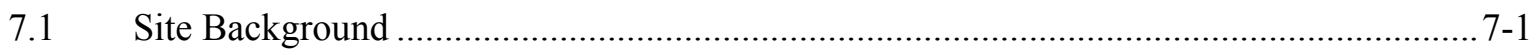

7.1.1 Summary of Remedial Design ..............................................................

7.2 Remediation and Demolition Activities ................................................................. $7-3$

7.2.1 Site Mobilization and Infrastructure Establishment ........................................ 7-3

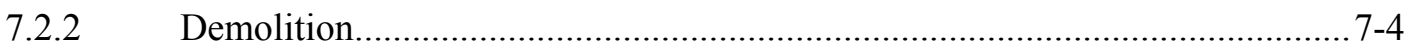

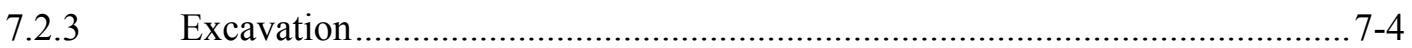

7.2.4 Area Completion .................................................................

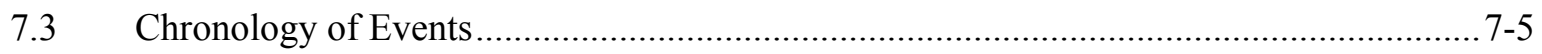

7.4 Performance Standards and Construction Quality Control .......................................... 7-7

7.4.1 Sampling Activities and Results ................................................................

7.4.2 ESP-034-04 Sampling Activity ……............................................ 7-8

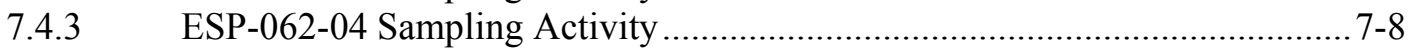

7.4.4 ESP-106-04 Sampling Activity ....................................................

7.4.5 ESP-116-04 Sampling Activity ……..............................................

7.4.6 Real-Time Instrumentation Results....................................................

7.5 Final Inspection and Certification .......................................................................

7.6 Site Contact Information ............................................................................... $7-11$

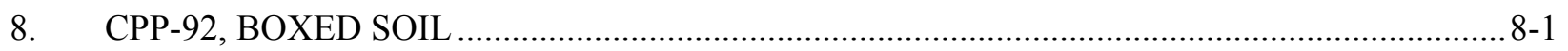

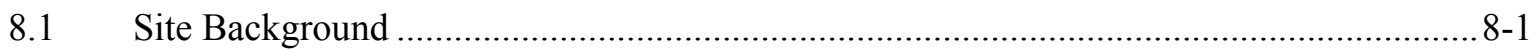

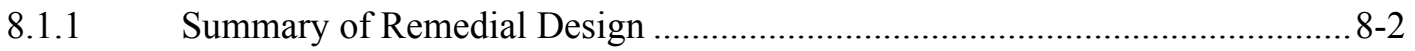

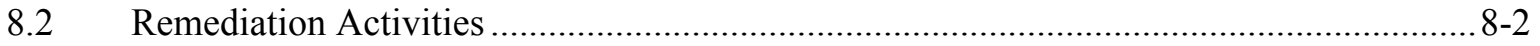

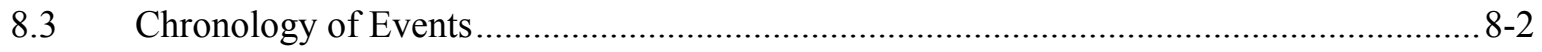

8.4 Performance Standards and Construction Quality Control ............................................ 8-3

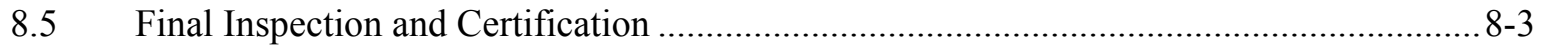

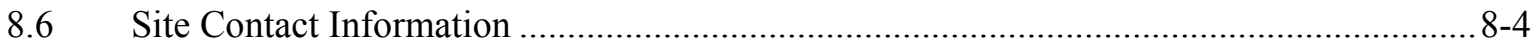


9. CPP-97, TANK FARM SOIL STOCKPILES FROM TANK FARM UPGRADE.

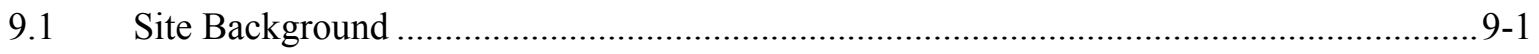

9.1.1 Summary of Remedial Design ............................................................... 9-1

9.2 Remediation and Demolition Activities ................................................................ 9-2

9.2.1 Site Mobilization and Infrastructure Establishment ........................................9-2

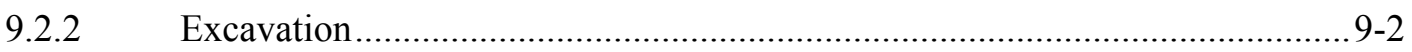

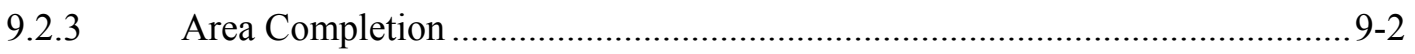

9.3 Chronology of Events ............................................................................................ $9-2$

9.4 Performance Standards and Construction Quality Control .......................................... 9-3

9.4.1 Sampling Activities and Results .......................................................... 9-4

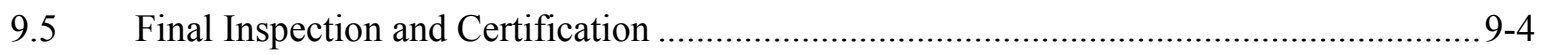

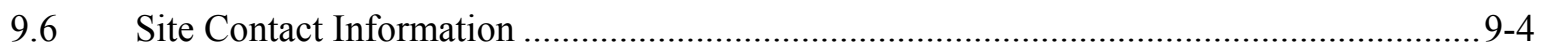

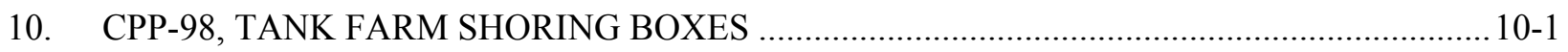

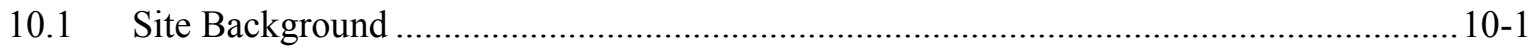

10.1.1 Summary of Remedial Design ........................................................ 10-1

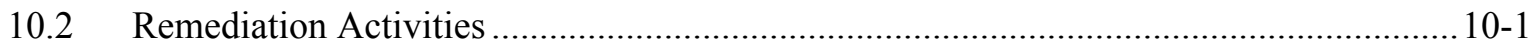

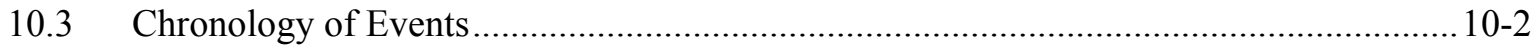

10.4 Performance Standards and Construction Quality Control ......................................... 10-2

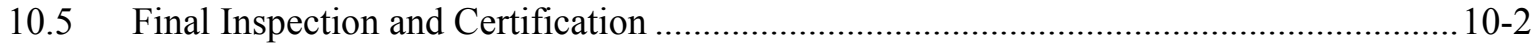

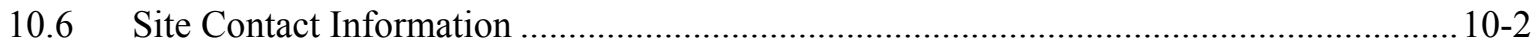

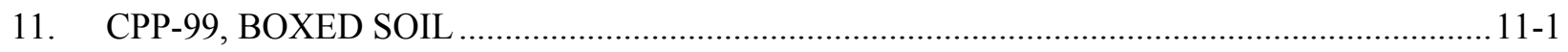

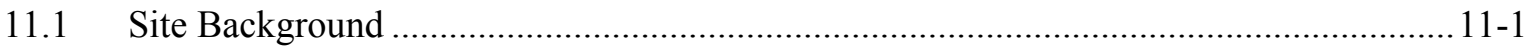

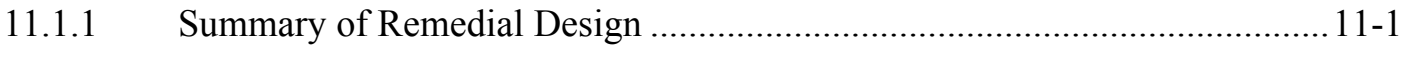

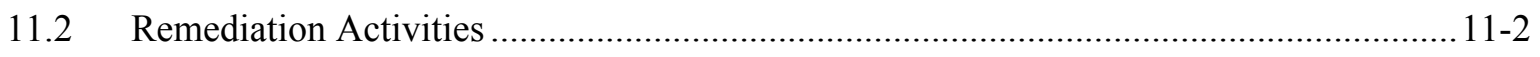

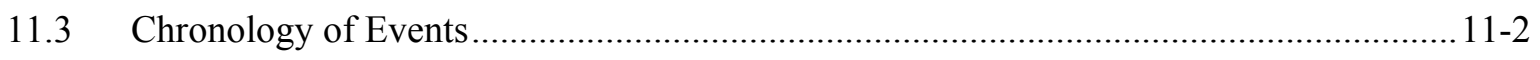

11.4 Performance Standards and Construction Quality Control ....................................... 11-3 
11.5 Final Inspection and Certification ..................................................................... 11-3

11.6 Site Contact Information ............................................................................... 11-3

12. PHASE I ADDITIONAL WORK SCOPE.......................................................................... 12-1

13. OPERATIONS AND SITE MAINTENANCE ................................................................... 13-1

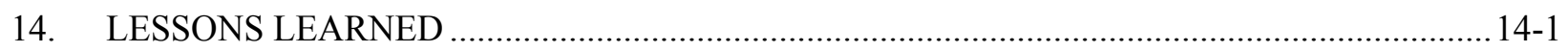

14.1 Soils Sampling Techniques ............................................................................ 14-1

14.2 Equipment and Contamination Control Techniques .............................................14-1

14.3 Preremediation Subsurface Investigation Techniques............................................ 14-2

15. SUMMARY OF PROJECT COSTS …............................................................................ 15-1

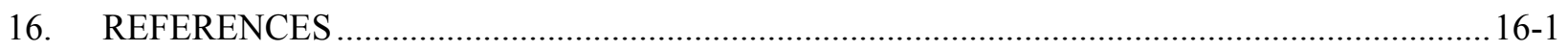

Appendix A —CPP-03 Characterization Sampling Data …............................................................ A-1

Appendix B —CPP-34A/34B High-Purity Germanium Data .......................................................... B-1

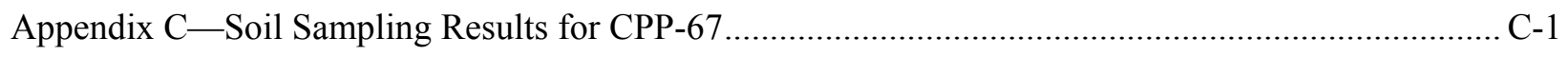

Appendix D — High-Purity Germanium Data for CPP-67, East and West Ponds................................ D-1

Appendix E—Gamma Scan Data for CPP-97: HPGe.................................................................... E-1

\section{FIGURES}

1-1. Idaho National Laboratory Site facilities and waste area group locations ................................. 1-3

1-2. Operable Unit 3-13, Group 3, Other Surface Soils, Remediation Sets 1-3 (Phase I) sites ............ 1-6

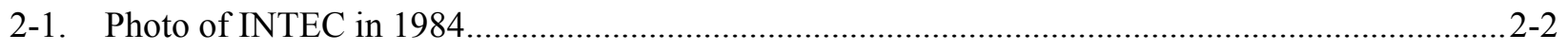

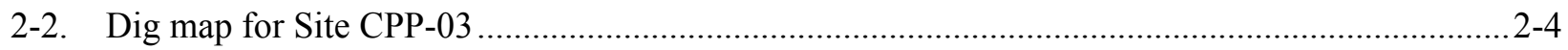

2-3. Site CPP-03 redefined boundaries in blue outline and new site, CPP-130, initial boundaries

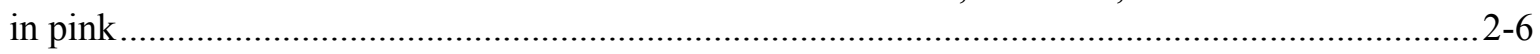

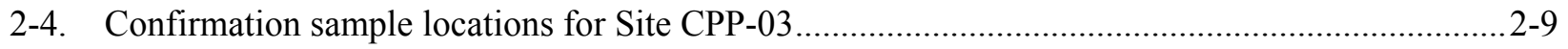

3-1. CPP-34A/34B high-purity germanium scans showing final excavation topography .....................3-3

7-1. Aerial photograph of CPP-67, west and east percolation ponds................................................

7-2. West percolation pond showing HPGe readings for $\mathrm{Cs}-137 \mathrm{in} \mathrm{pCi} / \mathrm{g}$ (no scale) ....................... 7-10 
7-3. East percolation pond showing HPGe readings for Cs-137 in $\mathrm{pCi} / \mathrm{g}$ (no scale).

9-1. Confirmation sampling locations for Site CPP-97

\section{TABLES}

1-1. Risk-based soil remediation goals

2-1. Comparison between risk-based remediation goals and performance levels achieved for CPP-03 soils

2-2. Site CPP-03 confirmation sampling results for Cs-137.

2-3. Chronology of events for the CPP-03 project

2-4. Contact information for the CPP-03 project $2-13$

3-1. Chronology of events for the CPP-34A/34B project.

3-2. Comparison between risk-based remediation goals and performance levels achieved for CPP-34A/34B soils

3-3. Confirmation sampling data summary of Cs-137 for Site CPP-34A/34B.

3-4. Confirmation sampling data summary of total strontium for Site CPP-34A/34B 3-6

3-5. Contact information for the CPP-34A/34B project

4-1. Chronology of events for the CPP-37A project..

5-1. Chronology of events for the CPP-37B project..

5-2. Contact information for the CPP-37B and CPP-37C projects

6-1. Chronology of events for the CPP-37C project

7-1. Chronology of events for the CPP-67 project

7-2. Comparison between risk-based remediation goals for OU 3-13, Other Soil Sites, and performance levels achieved for Site CPP-67

7-3. Environmental Services project soil sampling activities for CPP-67.

7-4. Contact information for the CPP-67 project

8-1. Chronology of events for the CPP-92 project

8-2. Contact information for the CPP-92, CPP-98, and CPP-99 projects.

9-1. Chronology of events for the CPP-97 project 
9-2. Comparison between risk-based remediation goals for OU 3-13, Other Soil Sites, and performance levels achieved for Site CPP-97

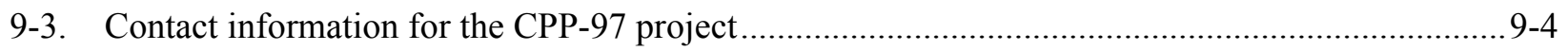

10-1. Chronology of events for the CPP-98 project ….......................................................... 10-2

11-1. Chronology of events for the CPP-99 project …........................................................... 11-2

13-1. Expected institutional control period for the sites reported in this Remedial Action Report........ 13-2 


\section{ACRONYMS}

\begin{tabular}{|c|c|}
\hline BBWI & Bechtel BWXT Idaho, LLC \\
\hline bgs & below ground surface \\
\hline CERCLA & Comprehensive Environmental Response, Compensation, and Liability Act \\
\hline $\mathrm{COC}$ & contaminant of concern \\
\hline DEQ & Department of Environmental Quality (Idaho) \\
\hline DOE & U.S. Department of Energy \\
\hline DOE-ID & DOE Idaho Operations Office \\
\hline EDF & Engineering Design File \\
\hline EPA & U.S. Environmental Protection Agency \\
\hline $\mathrm{FFA} / \mathrm{CO}$ & Federal Facility Agreement and Consent Order \\
\hline FSP & field sampling plan \\
\hline FY & fiscal year \\
\hline GDE & guide \\
\hline HPGe & high-purity germanium \\
\hline ICDF & Idaho CERCLA Disposal Facility \\
\hline ICP & Idaho Cleanup Project \\
\hline ICPP & Idaho Chemical Processing Plant \\
\hline INL & Idaho National Laboratory \\
\hline INTEC & Idaho Nuclear Technology and Engineering Center \\
\hline IWTS & Integrated Waste Tracking System \\
\hline $\mathrm{OU}$ & operable unit \\
\hline PCB & polychlorinated biphenyl \\
\hline PLN & plan \\
\hline QA & quality assurance \\
\hline QAPjP & Quality Assurance Project Plan \\
\hline
\end{tabular}




\begin{tabular}{ll} 
QC & quality control \\
RA & remedial action \\
RAO & remedial action objective \\
RCRA & Resource Conservation and Recovery Act \\
RD & remedial design \\
ROD & Record of Decision \\
SAP & sampling and analysis plan \\
SSA & Storage and Staging Annex \\
SSSTF & Staging, Storage, Sizing, and Treatment Facility \\
SVOC & semivolatile organic compound \\
SWP & service waste pond \\
TCLP & toxicity characteristic leaching procedure \\
TDEMI & time-domain electromagnetic induction \\
UCL & upper confidence limit \\
UTS & Universal Treatment Standard \\
VOC & volatile organic compound \\
WAC & Waste Acceptance Criteria \\
WAG & waste area group \\
\hline
\end{tabular}




\section{Operable Unit 3-13, Group 3, Other Surface Soils (Phase I) Remedial Action Report}

\section{INTRODUCTION}

The U.S. Department of Energy (DOE) submits this Remedial Action Report for Waste Area Group (WAG) 3, Operable Unit (OU) 3-13, Group 3, Other Surface Soils (Phase I), in accordance with the Federal Facility Agreement and Consent Order for the Idaho National Engineering Laboratory (DOE-ID 1991). The Federal Facility Agreement and Consent Order (FFA/CO) is an agreement between the DOE Idaho Operations Office (DOE-ID), the U.S. Environmental Protection Agency (EPA), and the Idaho Department of Environmental Quality (DEQ), hereafter referred to as the Agencies. This Remedial Action Report was prepared in accordance with requirements specified in the Operable Unit 3-13, Group 3, Other Surface Soils Remediation Sets 1-3 (Phase I) Remedial Design/Remedial Action Work Plan (DOE-ID 2004a).

\subsection{Purpose and Scope}

The purpose of this report is to document the completion of remedial actions (RAs) for WAG 3 , OU 3-13, Group 3, Phase I, soil sites, located within the boundaries of the Idaho National Laboratory (INL) Site at the Idaho Nuclear Technology and Engineering Center (INTEC).

The scope of this report includes presenting site descriptions and background; remedy requirements and remedial design (RD); descriptions of RAs, including characterization sampling; confirmation sampling results subsequent to the RAs; and chronology of related activities. This report addresses the following Group 3, Phase I, soil sites:

- CPP-03, Temporary Storage Area Southwest of CPP-603

- CPP-34 A/34B, Soil Storage Area in the Northeast Corner of INTEC

- CPP-37 A, Gravel Pit—Outside INTEC Fence (Gravel Pit \#1)

- $\quad$ CPP-37 B, Gravel Pit and Debris Landfill Inside INTEC Fence (Gravel Pit \#2)

- CPP-37 C, Contamination Discovered Southeast of CERCLA Site CPP-37B (new site adjacent to Gravel Pit \#2)

- CPP-67, Percolation Ponds

- CPP-92, Soil Boxes West of CPP-1617 (boxes of soil and debris in the Storage and Staging Annex [SSA])

- CPP-97, Soil Stockpiles

- CPP-98, Tank Farm Shoring Boxes (boxes of debris in the SSA)

- CPP-99, Boxed Soil (boxes of soil and soil and debris in the SSA).

\subsection{Organization of the Remedial Action Report}

This report is organized using the format, as appropriate, from the Close Out Procedures for National Priorities List Sites (EPA 2000), issued by the EPA Office of Solid Waste and Emergency Response. 
Section 1 provides a general background and discussion of factors that are common to all Phase I activities. This is followed by Sections 2 through 11, which are devoted to the specifics associated with individual sites. Sections 12 through 14 address topics that generally apply to all Phase I sites.

Appendixes provide the following information:

- Appendix A provides characterization sampling data for CPP-03.

- Appendix B provides high-purity germanium (HPGe) data for CPP-34A/34B.

- Appendix C provides soil sampling results in tabular form for CPP-67.

- Appendix D provides HPGe data for the east and west ponds of CPP-67.

- Appendix E provides HPGe data for CPP-97.

\subsection{Site Description and Background of the Idaho National Laboratory Site}

The INL Site (physical site and facilities) was established by the U.S. Atomic Energy Commission in 1949 as the National Reactor Testing Station for nuclear energy research and related activities. The National Reactor Testing Station was redesignated the Idaho National Engineering Laboratory in 1974 when it became a national laboratory under the direction of the Energy Research and Development Administration and subsequently under DOE in 1977. The Idaho National Engineering Laboratory mission changed during the post-cold-war era. The Idaho National Engineering Laboratory name was changed to the Idaho National Engineering and Environmental Laboratory to reflect greater significance of environmental management activities. By 2005, the Idaho National Engineering and Environmental Laboratory mission changed again to include added emphasis in nuclear engineering, homeland security, and environmental management. The Idaho National Engineering and Environmental Laboratory was split into the INL, operated by the Office of Nuclear Energy, Science, and Technology, and the Idaho Cleanup Project (ICP), operated by the Office of Environmental Management. As the long-term entity, the INL retained possession of the land and facilities, as well as nonenvironmental missions, while ICP took on the near-term cleanup mission associated with remediation of land and facilities and destruction and removal of facilities no longer needed to support INL missions. The newly designated INL underwent restructuring wherein it expanded and absorbed Argonne National Laboratory-West, renaming it the Materials and Fuels Complex, as well as many other facilities. Consequently, site maps and facility designations also have changed.

The INL Site is located in southeastern Idaho, beginning $51.5 \mathrm{~km}(32 \mathrm{mi})$ west of Idaho Falls (see Figure 1-1) and extending westward. The INL Site encompasses approximately $2,305 \mathrm{~km}^{2}\left(890 \mathrm{mi}^{2}\right)$ of the northeastern portion of the Eastern Snake River Plain and extends across portions of five Idaho counties: Butte, Jefferson, Bonneville, Clark, and Bingham.

In 1989, EPA proposed listing the INL Site on the National Priorities List of the National Oil and Hazardous Substances Pollution Contingency Plan (40 CFR 300). The EPA issued a final ruling that listed the Site as a National Priorities List site in November 1989 (54 FR 48184). As a result, the Site became subject to requirements of the Comprehensive Environmental Restoration, Compensation, and Liability Act (CERCLA) (42 USC $\S 9601$ et seq., 1980). The FFA/CO and associated action plan were developed to establish the procedural framework and schedule for developing, prioritizing, implementing, and monitoring response actions at the Site in accordance with CERCLA, the Resource Conservation and Recovery Act (RCRA) (42 USC $\S 6901$ et seq., 1976), and the Idaho Hazardous Waste Management Act (IC § 39-4401 et seq., 1983). 


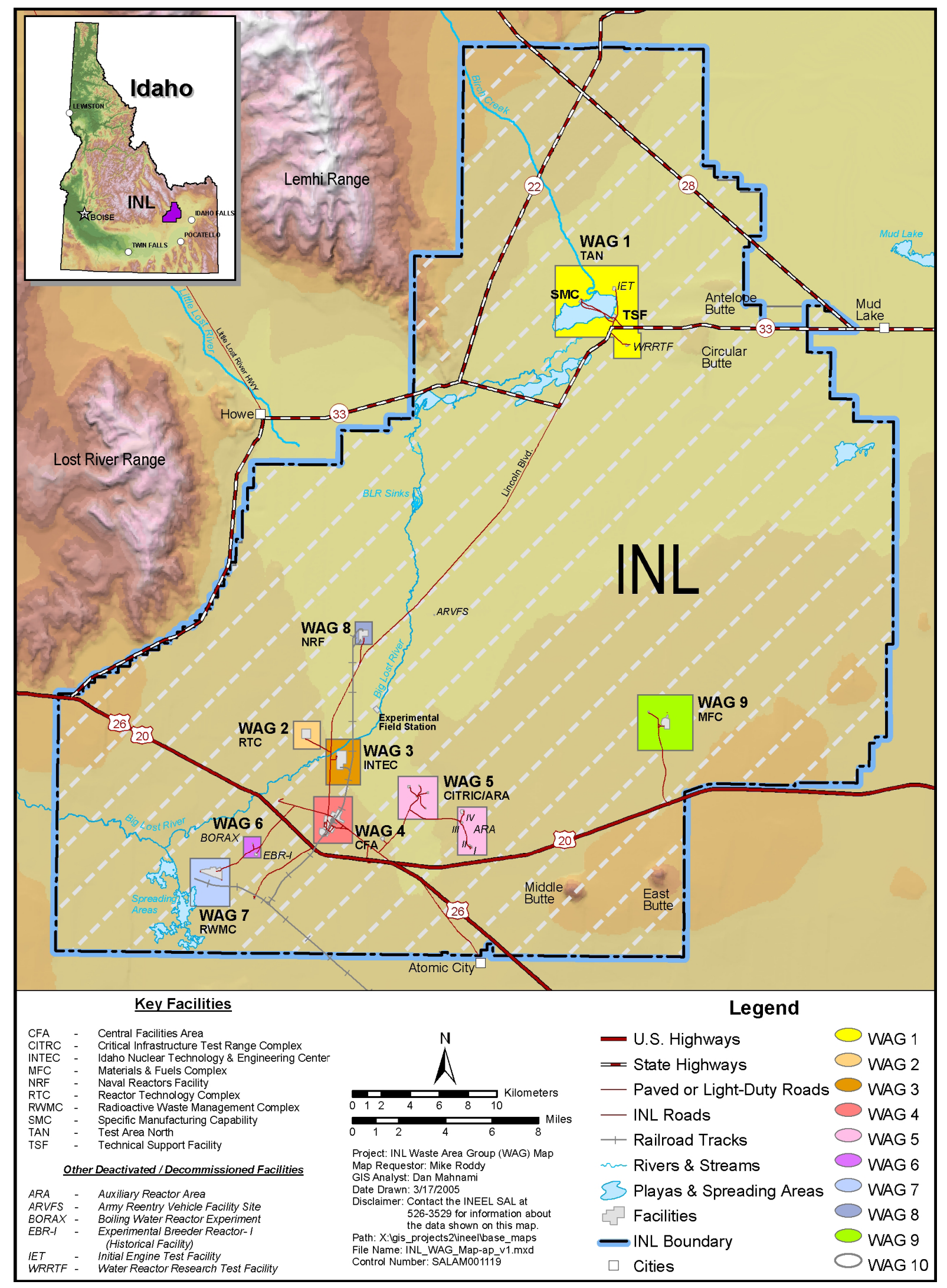

Figure 1-1. Idaho National Laboratory Site facilities and waste area group locations. 


\subsection{Background of INTEC and WAG 3 Operable Units}

\subsubsection{INTEC Site Location and Description}

The INTEC facility, formerly known as the Idaho Chemical Processing Plant (ICPP), is located in the southwestern portion of the INL Site (see Figure 1-1). INTEC is approximately $13 \mathrm{~km}(8 \mathrm{mi})$ north of the southern INL Site boundary and covers $0.4 \mathrm{~km}^{2}\left(0.15 \mathrm{mi}^{2}\right)$.

\subsubsection{Operations and Waste Management Practices that Contributed to Contamination in and around Various INTEC Facilities}

Primary missions at INTEC facilities have been associated with reprocessing spent nuclear fuel. Historically, the INTEC facility has been a uranium reprocessing facility for both defense projects and research while also acting as a storage facility for spent nuclear fuel. INTEC operated from 1952 to 1992, extracting reusable uranium from spent fuels. Liquid waste generated from the reprocessing activities, which ceased in 1992, is stored in an underground tank farm at INTEC. Both soil and groundwater contamination resulted from various piping and valve leaks during the course of normal operations. Ancillary activities supporting large-scale nuclear fuel reprocessing required similar large-scale use of solvents, fuels, chemicals, and construction materials. Storage and use of these materials also resulted in releases to the environment.

\subsubsection{WAG 3 , OU $3-13$}

There were 101 release sites identified for WAG 3. Subsequent to issuing the OU 3-13 Record of Decision (ROD) (DOE-ID 1999), all WAG 3 sites requiring remediation were combined into OU 3-13. Of the 101 release sites identified for WAG 3, 55 contaminant-release sites were identified within OU 3-13 as requiring RA to mitigate risk to human health and the environment under a future residential-use scenario. These sites then were divided into the following seven groups that share common characteristics and contaminant sources:

1. Group 1: Tank Farm Soils

2. Group 2: Soils Under Buildings and Structures

3. Group 3: Other Surface Soils

4. Group 4: Perched Water

5. Group 5: Snake River Plain Aquifer

6. Group 6: Buried Gas Cylinders

7. Group 7: SFE-20 Hot Waste Tank System.

Group 3, Other Surface Soils, sites comprise 29 of the 55 OU 3-13 release sites that required RA. These 29 sites were divided into six remediation sets, as documented in the Operable Unit 3-13, Group 3, Other Surface Soils, Prioritization and Site Grouping Report (DOE-ID 2002), which presents the criteria analysis used to determine how the Group 3 sites were grouped together and prioritized for remediation. 


\subsubsection{Identification of Phase I, Group 3, Sites}

This Remedial Action Report documents actions taken to remediate the WAG 3, Group 3, Other Surface Soils, Phase I, Sets 1, 2, and 3 sites at INTEC. These sites are listed below and illustrated in Figure 1-2:

\section{$\underline{\text { Remediation Set 1: }}$}

- CPP-92, Boxed Soil from Tank Farm Upgrade and Other INTEC Excavations

- CPP-97, Tank Farm Soil Stockpiles from Tank Farm Upgrade

- CPP-98, Tank Farm Shoring Boxes from Tank Farm Upgrade

- CPP-99, Boxed Soil from Tank Farm Upgrade and CPP-604 Tunnel Egress Excavation.

\section{Remediation Set 2:}

- CPP-37B, Gravel Pit and Debris Landfill Inside INTEC Fence

- CPP-37C, New Site Contamination Area Southeast of CPP-37B.

\section{$\underline{\text { Remediation Set 3: }}$}

- CPP-34A/34B, Soil Storage Areas (Disposal Trenches) in Northeast Corner of INTEC

- CPP-03, Temporary Storage Area Southeast of CPP-603

- CPP-37A, Gravel Pit Outside INTEC Fence

- CPP-67, Percolation Ponds 1 and 2.

\subsection{Remediation Goals for OU 3-13, Group 3, Other Surface Soils}

The 1999 OU 3-13 ROD (DOE-ID 1999) established remediation goals for soils (see Table 1-1). These goals are quantitative cleanup levels based primarily on risk to human health and the environment.

The generally acceptable risk range for site-related exposures under the National Oil and Hazardous Substances Pollution Contingency Plan (40 CFR 300) is $10^{-4}$ to $10^{-6}$. The Agencies agree that the acceptable risk for OU 3-13 is at the upper end of this range $\left(1 \times 10^{-4}\right)$ based on (1) the conservative nature of the risk assessments used at Group 3 sites; (2) use of the $1 \times 10^{-4}$ risk-based level in the OU 3-13 ROD for all CERCLA soil sites at INTEC; (3) the relative isolation of the INL Site; and (4) the annual carcinogenic risk at INTEC from natural background radiation due to surface elevation and background soil radiological contamination is estimated at $10^{-4}$. Table 1-1 presents risk-based soil concentrations corresponding to a $1 \times 10^{-4}$ risk or a hazard index of 1 for individual soil contaminants of concern (COCs). If more than one COC is present at a particular release site, these activities or concentrations will be modified so that the cumulative risk is $1 \times 10^{-4}$ or the hazard index is 1 . These risk-based remediation goals will be used to verify effectiveness of the selected RA and to determine whether additional RA (e.g., additional excavation) is necessary prior to closing the release site. 


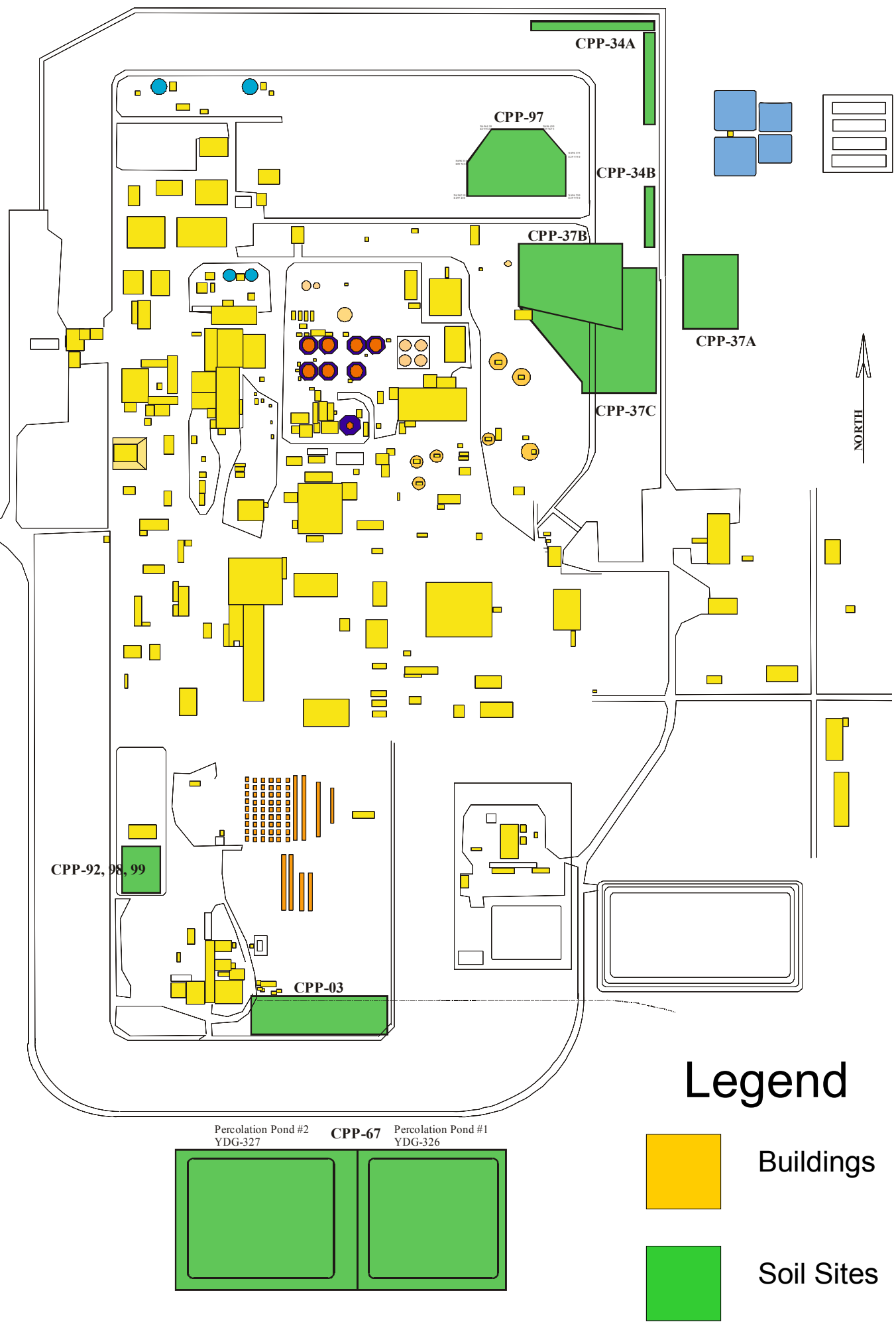

Figure 1-2. Operable Unit 3-13, Group 3, Other Surface Soils, Remediation Sets 1-3 (Phase I) sites. 
Table 1-1. Risk-based soil remediation goals.

Risk-Based Soil Remediation Goal ${ }^{\mathrm{a}}$ for Single Contaminants of Concern ${ }^{\mathrm{b}}$

Contaminant of Concern $(\mathrm{pCi} / \mathrm{g})$

\section{Radionuclides}

Am-241 290

Cs-137

23

Eu-152

270

Eu-154

5,200

$\mathrm{Pu}-238$

670

$\mathrm{Pu}-239 / 240$

250

$\mathrm{Pu}-241$

56,000

Sr-90

223

\section{Nonradionuclides ${ }^{\mathrm{c}}$}

Mercury (human health)

23

a. Source of risk-based soil remediation goals: Table 2-1 of the OU 3-13 Remedial Investigation and Feasibility Study (DOE-ID 1997). Risk-based remediation goals developed for residential scenario.

b. If multiple contaminants are present, use a sum of the fractions to determine combined COC remediation goal.

c. The mercury remediation goal was selected from the EPA Region 3, April 1996, screening guidance for soil ingestion under the residential scenario. (EPA 2007. Note: The EPA mercury remediation goal for 2007 is the same as it was in 1996.) 


\section{SITE CPP-03, TEMPORARY STORAGE AREA SOUTHEAST OF CPP-603}

\subsection{Site Background}

\subsubsection{Site CPP-03 Location and Description}

Site CPP-03 is located in the south-central portion of INTEC within the facility security fence boundaries (see Figure 1-2). Current physical boundaries of Site CPP-03 are defined by corner markers on the west side (approximately $10 \mathrm{~m}$ [33 ft] east of Building CPP-603), Willow Avenue to the south, Evergreen Street to the east, and the railroad tracks to the north. Dimensions of Site CPP-03 are approximately $45.7 \mathrm{~m}(150 \mathrm{ft})$ (north to south) $\times 152.4 \mathrm{~m}(500 \mathrm{ft})$ (east to west).

\subsubsection{Operations and Waste Management Practices that Contributed to Contamination at Site CPP-03}

Site CPP-03 is the location of a former temporary storage area southeast of Building CPP-603, the Fuel Receiving and Storage Facility. The area was used to store old and abandoned radioactive contaminated equipment (e.g., tanks, valves, and fuel casks). The recent discovery of some 1974 records indicates that the eastern third of the site was used previously as a construction landfill and that a pit existed in the southeast-central area of the site, running east to west. The storage area was decommissioned in the mid-1970s, and contaminated equipment and soil were packed into standard wooden radioactive waste boxes and taken to the Radioactive Waste Management Complex. The top several inches of underlying soil were contaminated due to storage of contaminated equipment in the area. Most of the contaminated soil was removed, boxed, and sent to the Radioactive Waste Management Complex for disposal. Approximately $29 \mathrm{~cm}$ (11 in.) of uncontaminated soil were placed over the area south of the railroad tracks and then graded to a level surface.

During the summer of 1983, excavation was conducted in the tank farm area to replace Tank WL-102. Radioactive contaminated soil was encountered in the dig, and approximately $9,270 \mathrm{~m}^{3}\left(12,000 \mathrm{yd}^{3}\right)$ of excavated contaminated soil (less than $30 \mathrm{mR} /$ hour) from the WL-102 Tank Replacement Project were transported to Site CPP-03 for temporary storage. Following removal of soil to CPP-34A/34B, clean soil was placed over the staging site, covering the area from which the contaminated soil was removed to an approximate depth of $15 \mathrm{~cm}$ (6 in.). In August and September 1984, the contaminated soil was placed in trenches in the northeast corner of the ICPP (i.e., INTEC) (later designated as CERCLA Site CPP-34A/34B).

The 1984 photograph in Figure 2-1 shows that the WL-102 soil was not stored on the railroad tracks nor on the south and east perimeter roads of the ICPP (i.e., INTEC). Additionally, the WL-102 soil pile was limited to the eastern two-thirds of the CPP-03 area and did not extend over the western one-third of the site. The photo also indicates that the portion of Site CPP-03 north of the railroad tracks was used to store materials and equipment.

- Zone north of the railroad tracks - The zone north of the railroad tracks was used for occasional storage of equipment and materials. The zone north of the railroad tracks was not covered by additional soil; therefore, any residual contamination would be evident on the surface.

- Zone south of the railroad tracks-This zone was used for storage of equipment and material. Soil and material were removed from this area in the mid-1970s; then the area was covered with up to $20 \mathrm{~cm}$ (11 in.) of soil. 


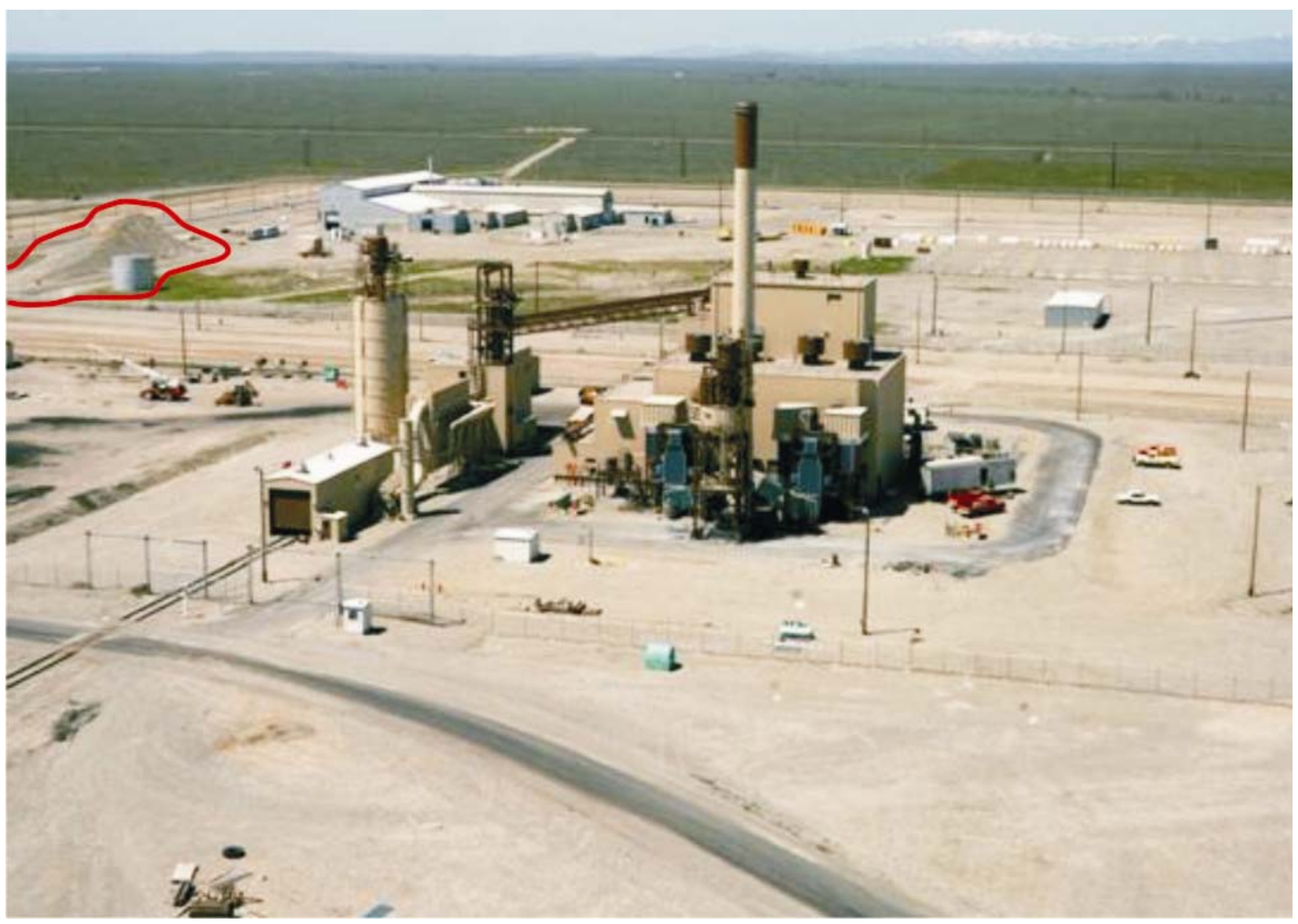

Figure 2-1. Photo of INTEC in 1984. Soil pile on Site CPP-03 area is bounded by the single red line. 
2.1.2.1 Post-ROD Investigations at CPP-03. Preexcavation sampling was conducted at Site CPP-03 in the summer of 2006 to further characterize the extent of contamination and to develop a dig plan for the site. Sampling was conducted in accordance with the Operable Unit 3-13, Group 3, Site CPP-03 Field Sampling Plan (DOE-ID 2005a). Characterization sampling involved collecting soil core samples from 39 predesignated sample locations $(1.1 \mathrm{~m}[3.5 \mathrm{ft}]$ deep at 12.2-m [40-ft] intervals) over the site. Sixteen additional sampling holes were examined at locations spreading out radially from holes with contamination above the $23-\mathrm{pCi} / \mathrm{g}$ remediation goal to determine the lateral extent of contamination. Radiologic measurements were made in the sampling holes at 0.2-, 0.3-, 0.6-, and 0.9-m (0.5-, 1, 2-, and $3-\mathrm{ft}$ ) depth intervals for each of the 55 holes made during the characterization effort. Measurements were made with a small-diameter area monitor probe (AMP-50) that was sensitive to radiation fields extending to approximately 20 to $30 \mathrm{~cm}$ ( 8 to $12 \mathrm{in}$.) through the soil. Thirty-seven unique soil samples (grid location and depth) also were collected (42 including duplicates) from cores at 27 different sample (grid) locations. Soil samples (pucks) were analyzed for Cs-137 activity. Appendix A presents the raw data.

Down-hole radiologic measurements were compared to the soil sample activities to establish a correlation between them. Examination of the holes individually resulted in identifying areas above the remediation goals, and the results were used to define excavation boundaries within the site. A regression plot of the data and the excavation plan shown in Figure 2-2 were presented to the Agencies and discussed during a conference call on July 25, 2006; the plot and plan were verbally accepted.

Boundaries were placed on the site following a radiofrequency geophysical survey on August 11, 2006, to identify subsurface utilities. Excavation began on August 28, 2006. While excavating the eastern portion of the site, an empty drum was uncovered at a shallow depth on September 11, 2006. No debris of this nature or size was expected, and excavation halted temporarily to evaluate the need for additional subsurface investigation. The drum, along with the soil surrounding it, were analyzed for radiological constituents. Results showed residue inside the drum to be radiologically contaminated with alpha nuclides not generally characteristic of the site nor consistent with the waste profile. Soil samples around the drum site did not contain alpha nuclides and were below the remediation goals for known contaminants.

A series of subsurface investigations were then conducted over the entirety of the site not already excavated. While excavation was curtailed, a time-domain electromagnetic induction (TDEMI) survey was conducted over the site to assess the area for conductive subsurface anomalies.

The TDEMI survey was conducted with high sensitivity to objects located within $3 \mathrm{~m}(10 \mathrm{ft})$ of the surface. This produced a map identifying the location of over 300 anomalies. Screening criteria were applied to remove objects containing less than approximately $0.45 \mathrm{~kg}(1 \mathrm{lb})$ of metal. This reduced the number of anomalies to just over 100, with 38 anomalies of significant size remaining. Exact numbers are nebulous because the map resolution is not sufficient to distinguish multiple objects in close proximity to others. Some anomalies within the site were outside the planned CPP-03 excavation boundaries.

It was unclear whether the remaining anomalies were construction debris or container-type vessels. Small-sized construction debris were expected to be present on the site and uncovered during the dig, but large debris and drums were not. Because of uncertainty associated with the debris, there are unknown hazards that require increased caution and work control to unearth and manage. 


\section{Excavation Sketch for CPP-03 Remediation}

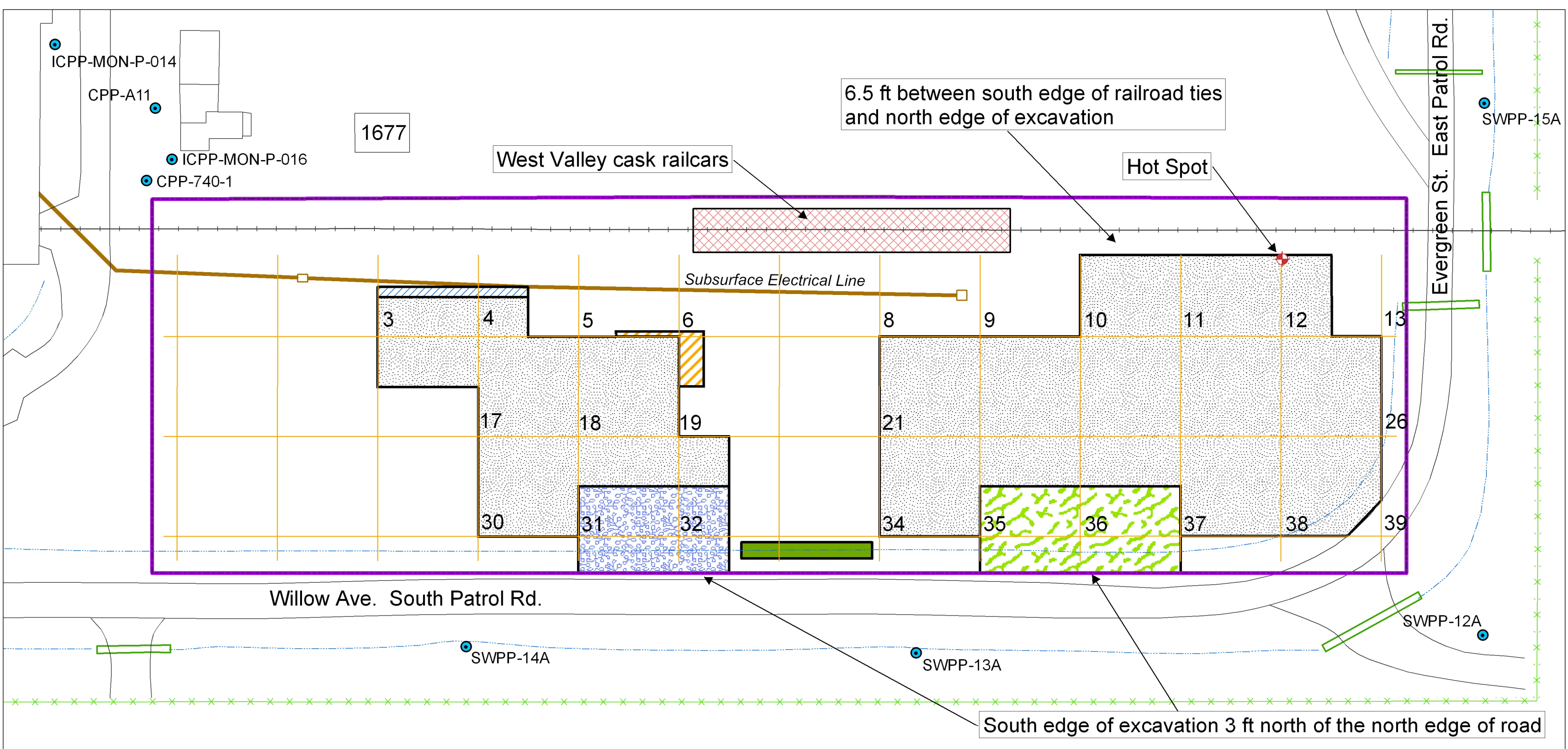

Excavation minimum depth $3 \mathrm{ft}$ below ground surface - mechanical excavation allowed per subsurface investigation results Excavation minimum depth $2 \mathrm{ft}$ below ground surface - mechanical excavation allowed per subsurface investigation results Excavation minimum depth $1 \mathrm{ft}$ below ground surface - mechanical excavation allowed per subsurface investigation results Approximate location of surface contamination area - mechanical excavation allowed per subsurface investigation results 0 Approximate location of hand or vacuum excavation to a minimum of $3 \mathrm{ft}$ below ground surface per the subsurface investigation results Approximate location of temporary backfill of ditch for vehicle access, if necessary

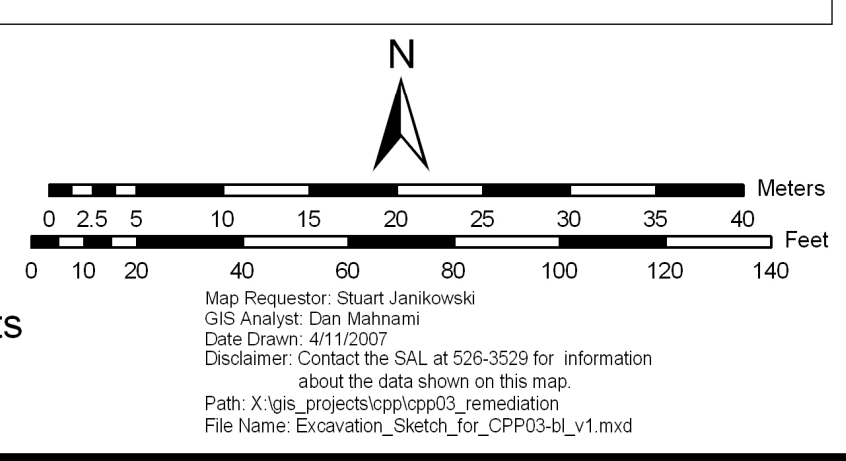

Figure 2-2. Dig map for Site CPP-03. 
The complexity and hazards associated with excavation increased substantially with this new geophysical information. The ground surface was painted to mark edges of the anomalies; then borders around the anomalies were painted to mark off a $1.5-\mathrm{m}(5-\mathrm{ft})$ distance. To avoid further delays, which would have resulted in halting the excavation for the winter, the site was further partitioned into two types of areas. The first type is where no anomalies would be excavated and where the anomaly density was low enough to be excavated to the $1.5-\mathrm{m}(5-\mathrm{ft})$ boundary from the anomaly without disturbing the anomaly. The second area type was where the anomaly density was high or where anomalies were known to be of a size and conductive (metal) mass corresponding to an object the size of a small cylinder or larger. The former areas remained part of Site CPP-03 and were excavated; the latter areas were grouped into a new site designation, Site CPP-130. Figure 2-3 shows excavation boundaries for Site CPP-03 with the areas in pink redesignated as Site CPP-130.

In December 2006, after completion of the modified CPP-03 excavation, the area inside CPP-03 boundaries, but outside the excavation, underwent further investigation. This allowed characterization of the remaining area to aid in determining the new site (i.e., CPP-130). The expansion would include isolated areas not adequately sampled during the summer 2006 characterization activities, due to the possibility of localized contamination attached to large pieces of debris or buried containers not previously known. An additional TDEMI survey (at 0.5-m [20-in.] resolution over the whole site) was performed on the area outside the excavation boundaries, including the area north of the railroad tracks.

In January 2007, an additional survey was conducted using balanced, cesium optically pumped magnetometers. This system and technique is highly sensitive to changes in the earth's magnetic field caused by the presence of ferromagnetic materials. Iron-bearing materials in the soil (or anywhere close) distort the earth's magnetic field, which the magnetometer measures accurately. Field measurements enable calculation of more accurate depth and mass determinations for subsurface anomalies with iron components (e.g., iron cylinders, iron drums, and iron rebar). However, this technique does not respond to other materials. Underground electrical utilities were off during this investigation and did not interfere with measurements. This investigation was conducted over the entire site to the same degree as the TDEMI investigation.

Results of the TDEMI investigation conducted in December 2006 and the magnetometer investigation conducted in January 2007 are not reported here. Areas within Site CPP-03 and immediately surrounding the site containing contamination above remediation goals, but not excavated because of subsurface anomalies, will become Site CPP-130. Boundaries will be defined after further characterization efforts to identify and evaluate contamination associated with subsurface anomalies. Site CPP-130 will include the areas marked in pink in Figure 2-3, plus any areas inside Site CPP-03 not previously excavated and found to have contamination above the remediation goal. These latter characterization activities and corresponding remediation of the site will be conducted as part of Group 3, Phase II, and reported to the Agencies in subsequent reports.

\subsubsection{Summary of CPP-03 Remedial Design}

The original RD for CPP-03 from the Phase I RD/RA Work Plan (DOE-ID 2004a) called for excavating the entire site and removing all structures included in that footprint. This also required rebuilding of the removed fences and roads. Careful review of historical aerial photographs verified that contaminated soil and equipment staged at CPP-03 were in a smaller footprint. Based on this, a specific OU 3-13 Phase I Field Sampling Plan (FSP) (DOE-ID 2004b) for the CPP-03 site, to further refine the footprint of the areas to be remediated, was reviewed and approved by the Agencies.

The cleanup goal for CPP-03 was to remove contamination from the site to achieve risk-based remediation goals identified in Table 1-1. 




Figure 2-3. Site CPP-03 redefined boundaries in blue outline and new site, CPP-130, initial boundaries in pink. 
Major components of the selected remedy for CPP-03 included

- Remove contaminated soil and debris from CPP-03 using conventional excavation methods

- Dispose of contaminated soils and debris in the Idaho CERCLA Disposal Facility (ICDF)

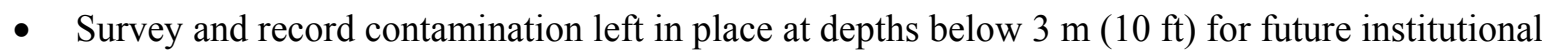
controls, as necessary

- Replace excavated soil with clean backfill and regrade.

NOTE: The remedy specified backfilling the excavation to the surrounding elevation; however, discussions with INTEC facility management determined that no future use was expected for the excavation area. Therefore, clean soil cover was placed over the excavation to a nominal depth of $15.2 \mathrm{~cm}$ (6 in.), leaving the excavated depressions with gradual side slopes. This was discussed during a weekly Agency conference call and again during the prefinal inspection.

The remedy also specified that eight random soil samples would be collected from locations identified in the Phase I FSP. This was modified and expanded to include nine additional biased samples, as discussed below:

- The eight random samples were collected within the excavation.

- Seven of the nine biased samples were collected within the excavation in the ditch area.

- The eighth biased sample was collected from outside the original excavation, in an extension of the excavation, to remediate a hot spot.

- The ninth biased sample was collected from an area that required additional excavation to remove a hot spot.

- Hot spot locations were identified using a $\mathrm{NaI}$ or $\mathrm{LaBr}_{3}$ gamma detector.

\subsection{Remediation and Demolition Activities}

\subsubsection{Site Preparation}

In August 2006, a geophysical land survey was conducted to mark and record excavation boundaries. The southeastern boundary of the site (and excavation) also was remapped at that time to follow the curvature of the two roads adjacent to site boundaries. This survey was conducted to avoid excavating the asphalt roads.

Also in August 2006, earthwork equipment was mobilized to the site, and the area directly associated with the RA was cleared of vegetation. Fencing and temporary boundary ropes were removed or installed, as necessary.

A culvert was placed in the ditch along the south-central boundary of the site (between the two excavation areas) and was backfilled to provide a ramp over which haul vehicles could enter and exit the site. A tarping station was erected just north of the installed ramp (within the site and between the two excavation areas), which provided access to the haul equipment for transporting the soil to ICDF and also to complete radiologic surveys prior to exiting the site. 


\subsubsection{Contaminated Soil Excavation and Disposal}

Excavation of the site began on August 28, 2006, and continued through December 11, 2006. Soil was transported using articulated trucks and roll-on/roll-off containers. Trucks removed 162 loads from the site, for a total deposit of 2,620 tons of soil in ICDF. Roll-on/roll-off containers removed 223 loads from the site, for a total deposit of 2,077 tons of soil in ICDF. The combined total amount of soil removed was 4,698 tons. The soil was wetted during excavation for dust suppression and estimated at 1.7 tons/yd $\mathrm{d}^{3}$. This brings the estimated volume of the excavated material to $2,113 \mathrm{~m}^{3}\left(2,764 \mathrm{yd}^{3}\right)$.

The excavation encroached on Willow Avenue to the south and Evergreen Street to the east, such that storm water drainage ditches adjacent to the roads were compromised (i.e., sections of the ditches were excavated). Confirmation sampling was completed in the excavated ditch areas; whereafter, the ditches were backfilled with clean soil and contoured so they would be functional.

\subsubsection{Site CPP-03 Confirmation Sampling}

Site sampling was an ongoing activity throughout the excavation phase. The OU 3-13 CPP-03 FSP (DOE-ID 2005a) called for collecting eight random confirmation samples from the excavation in areas having the highest residual activity based on wide-area gamma scans collected using an HPGe detector. An alternate approach was adopted. The approach incorporated using a portable gamma detector to scan the excavation floor shortly after it was uncovered and before the excavator moved out of reach. In this way, the radiologically hot spots were identified quickly and further remediated without having to build a land bridge to them or having equipment contaminated upon entering the excavation to remediate the hot spot. A $1.5-\times 1.5-\mathrm{m}(5-\times 5-\mathrm{ft})$ grid was established over the excavation, and eight confirmatory sampling sites were then randomly selected, from which soil samples were collected in the region 0 to $15.2 \mathrm{~cm}(0$ to 6 in.) deep. Figure 2-4 shows the confirmation sampling locations. The eight randomly selected locations correspond to the grids labeled as 121,146, 187, and 402 in the western excavation and 63, 265, 368, and 174 in the eastern excavation.

An additional nine biased sampling locations were selected, as shown in Figure 2-4. The six locations designated by Grids 406, 409, 479, 457, 424, and 279 were collected in the ditch area, which needed to be backfilled and contoured to avoid disrupting the storm water drainage system for that region of INTEC. The polygon-shaped areas outlined by dashed lines represent hot spots located with the gamma detector. These areas were excavated further, and three biased soil samples were collected to demonstrate that soil above the remediation goal was removed. Two of the three biased samples were from Grid Area 227 in the western excavation and Grid Area 487 in the eastern excavation. The third biased sample location was in the hot spot in the eastern excavation, which extended beyond the excavation boundary. The excavation then proceeded outside the boundary and encompassed the portion of contaminated soil shown on the map and bounded by the dashed line, but outside the boundary lines. A biased sample then was collected from the Grid 491 area to confirm that the contaminated soil was removed. 


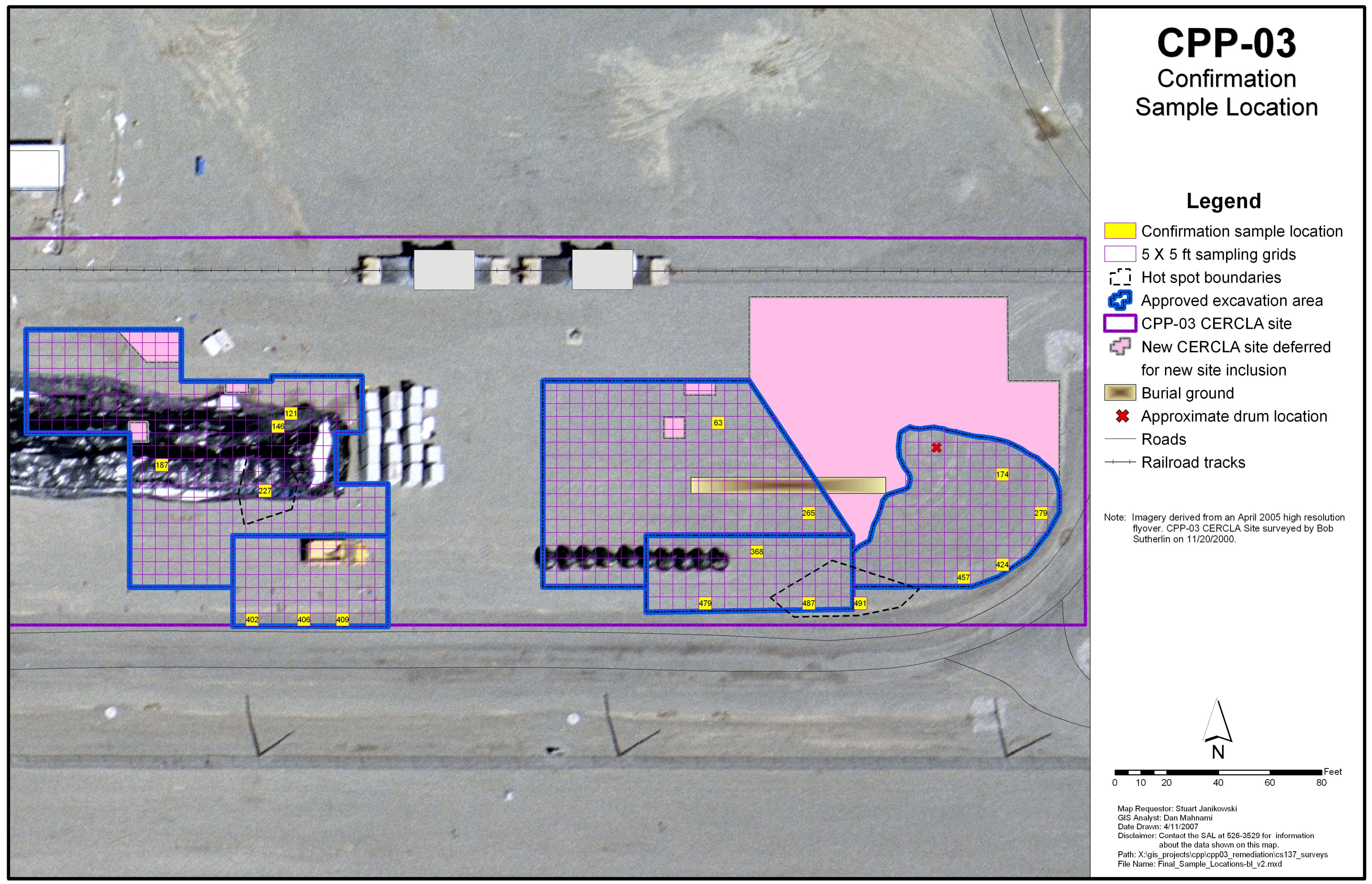

Figure 2-4. Confirmation sample locations for Site CPP-03. 
Data were validated in accordance with a Level B validation, as defined in Guide (GDE) -7003, "Levels of Analytical Method Data Validation." All the samples are below the 23-pCi/g remediation goal for the COC for this site (i.e., Cs-137) (see Table 2-1). Data are summarized in Table 2-2.

Table 2-1. Comparison between risk-based remediation goals and performance levels achieved for CPP-03 soils.

\begin{tabular}{|c|c|c|}
\hline $\begin{array}{c}\text { Contaminant } \\
\text { of Concern }\end{array}$ & $\begin{array}{l}\text { Soil Risk-Based Remediation } \\
\text { Goal for Single Contaminants of } \\
\text { Concern } \\
(\mathrm{pCi} / \mathrm{g})\end{array}$ & $\begin{array}{c}\text { Performance } \\
\text { Level Achieved } \\
95 \% \mathrm{UCL}^{\mathrm{a}}(\mathrm{pCi} /)\end{array}$ \\
\hline Cs-137 & 23 & 1.95 \\
\hline
\end{tabular}

\subsubsection{Area Completion}

The excavation was partially backfilled with clean soil after the confirmation sample analyses results became known. Backfill soil was placed along banks of the excavation to allow contouring $(1: 2$, rise:run) from the surrounding surface to the bottom of the excavation. In addition, soil was placed in the bottom of the excavation to provide a nominal 15.2-cm (6-in.) cover. Repeated movement of the haul and contouring equipment over the backfill area packed the soil and resulted in a stable smooth surface. Radiological control technicians then surveyed the entire base of the excavation with portable $\beta / \gamma$ friskers and free-released the site. A grader then contoured fill areas along the ditches to restore drainage capability. Ditches were contoured over their full length, but freezing soil conditions precluded cutting them to the final grade. The ditches have been identified for completion of final grade contours during summer 2007.

The standard deviation $(s)$ was calculated according to:

$$
\mathrm{s}=\sqrt{\frac{\sum(\mathrm{x}-\overline{\mathrm{x}})^{2}}{\mathrm{n}-1}}
$$

where

$$
\begin{aligned}
& x=\text { sample value } \\
& \bar{x}=\text { sample average } \\
& n=\text { sample size. }
\end{aligned}
$$

The half-width of a confidence interval for the true mean $(\mu)$ at the $95 \%$ level was calculated according to:

$$
\mathrm{t}_{0.95, \mathrm{n}-1} \frac{\mathrm{s}}{\sqrt{\mathrm{n}}}
$$

where $t$ is the Student's $t$ value for the $95^{\text {th }}$ percentile of the distribution.

The $95 \%$ upper confidence limit (UCL) for the mean $(\mu)$ was calculated as

$$
\mathrm{UCL}=\overline{\mathrm{x}}+\mathrm{t}_{0.95, \mathrm{n}-1} \frac{\mathrm{s}}{\sqrt{\mathrm{n}}}
$$


Table 2-2. Site CPP-03 confirmation sampling results for Cs-137.

\begin{tabular}{|c|c|c|c|c|c|c|c|c|}
\hline Grid $^{\mathrm{a}}$ & $\begin{array}{l}\text { Sample Result } \\
(\mathrm{pCi} / \mathrm{g})\end{array}$ & $\begin{array}{l}\text { Sample Error } \\
(\mathrm{pCi} / \mathrm{g})\end{array}$ & $\begin{array}{c}\text { Validation } \\
\text { Flag }^{\mathrm{b}}\end{array}$ & $\begin{array}{l}\text { Date Sample } \\
\text { Collected }\end{array}$ & $\begin{array}{c}\text { Minimum } \\
\text { Detectable } \\
\text { Activity }\end{array}$ & $\begin{array}{l}\text { Limitations and } \\
\text { Validation Report } \\
\text { Number }\end{array}$ & $\begin{array}{l}\text { Field Sample } \\
\text { Number }\end{array}$ & $\begin{array}{l}\text { Lab Sample } \\
\text { Number }\end{array}$ \\
\hline 279 & $3.22 \mathrm{E}+00$ & $6.93 \mathrm{E}-02$ & & $11 / 06 / 2006$ & $6.43 \mathrm{E}-02$ & BAM-061-06 & E0790600801R4 & 176447001 \\
\hline 424 & $2.10 \mathrm{E}+00$ & $1.07 \mathrm{E}-01$ & & $11 / 06 / 2006$ & $2.78 \mathrm{E}-02$ & BAM-061-06 & E0790600901R4 & 176447002 \\
\hline 457 & $6.28 \mathrm{E}+00$ & $2.37 \mathrm{E}-01$ & & $11 / 14 / 2006$ & 4.32E-02 & BAM-061-06 & E0790601001R4 & 176447003 \\
\hline 121 & $1.40 \mathrm{E}-01$ & $3.49 \mathrm{E}-02$ & & $11 / 29 / 2006$ & $7.09 \mathrm{E}-02$ & SOS-TL022-07 & E0790600001R4 & 177148001 \\
\hline 146 & $6.06 \mathrm{E}-01$ & $6.10 \mathrm{E}-02$ & & $11 / 29 / 2006$ & $9.13 \mathrm{E}-02$ & SOS-TL022-07 & E0790600101R4 & 177148002 \\
\hline 146 & $3.28 \mathrm{E}-01$ & 4.90E-02 & & $11 / 29 / 2006$ & $1.02 \mathrm{E}-01$ & SOS-TL022-07 & E0790600102R4 & 177148003 \\
\hline 187 & $2.37 \mathrm{E}-01$ & 3.91E-02 & & $11 / 29 / 2006$ & 8.49E-02 & SOS-TL022-07 & E0790600201R4 & 177148004 \\
\hline $402 \mathrm{~A}$ & $7.20 \mathrm{E}-02$ & $2.53 \mathrm{E}-02$ & UJ & $11 / 29 / 2006$ & $8.18 \mathrm{E}-02$ & SOS-TL022-07 & E0790600301R4 & 177148005 \\
\hline $402 \mathrm{~B}$ & $2.91 \mathrm{E}-01$ & $4.32 \mathrm{E}-02$ & & $11 / 29 / 2006$ & $7.96 \mathrm{E}-02$ & SOS-TL022-07 & E0790601101R4 & 177148006 \\
\hline $402 \mathrm{C}$ & $4.54 \mathrm{E}-01$ & $6.05 \mathrm{E}-02$ & & $11 / 29 / 2006$ & $8.83 \mathrm{E}-02$ & SOS-TL022-07 & E0790601201R4 & 177148007 \\
\hline 63 & $1.88 \mathrm{E}-01$ & $2.08 \mathrm{E}-02$ & & $12 / 12 / 2006$ & $2.51 \mathrm{E}-02$ & SOS-TL026-07 & E0790600401R4 & 178020001 \\
\hline 256 & $1.95 \mathrm{E}-01$ & 7.17E-02 & $\mathrm{J}$ & $12 / 12 / 2006$ & $5.81 \mathrm{E}-02$ & SOS-TL026-07 & E0790600501R4 & 178020002 \\
\hline 368 & $7.95 \mathrm{E}-01$ & $6.29 \mathrm{E}-02$ & & $12 / 12 / 2006$ & $7.68 \mathrm{E}-02$ & SOS-TL026-07 & E0790600601R4 & 178020003 \\
\hline 174 & $2.42 \mathrm{E}+00$ & $6.82 \mathrm{E}-02$ & & $12 / 12 / 2006$ & $6.83 \mathrm{E}-02$ & SOS-TL026-07 & E0790600701R4 & 178020004 \\
\hline 479 & $1.01 \mathrm{E}+00$ & $7.03 \mathrm{E}-02$ & & $12 / 12 / 2006$ & $3.43 \mathrm{E}-02$ & SOS-TL026-07 & E0790601301R4 & 178020005 \\
\hline 487 & $6.80 \mathrm{E}-02$ & $1.73 \mathrm{E}-02$ & & $12 / 12 / 2006$ & $2.21 \mathrm{E}-02$ & SOS-TL026-07 & E0790601401R4 & 178020006 \\
\hline 491 & $1.03 \mathrm{E}+00$ & 7.64E-02 & & $12 / 12 / 2006$ & 4.34E-02 & SOS-TL026-07 & E0790601501R4 & 178020007 \\
\hline 227 & $1.29 \mathrm{E}+00$ & 4.79E-02 & & $12 / 12 / 2006$ & $5.97 \mathrm{E}-02$ & SOS-TL026-07 & E0790601601R4 & 178020008 \\
\hline \multicolumn{9}{|c|}{ Summary Information } \\
\hline \multicolumn{9}{|c|}{ Average activity } \\
\hline & \multicolumn{2}{|c|}{6.28} & & \\
\hline & & & \multicolumn{2}{|c|}{$\begin{array}{l}\text { Maximum activity } \\
\text { Standard deviation }\end{array}$} & \multicolumn{2}{|c|}{1.60} & & \\
\hline & & & \multicolumn{2}{|c|}{$95 \% \mathrm{UCL}$} & \multicolumn{2}{|c|}{1.95} & & \\
\hline
\end{tabular}

a. Grid 402A in this table corresponds to Grid 402 in Figure 2-4. Similarly, Grid 402B corresponds to Grid 406, and Grid 402C corresponds to Grid 409.

b. No flag = The analysis was performed and radioactivity was detected (statistically positive at the $95 \%$ confidence interval and is above the minimum detectable activity). The radionuclide is considered to be present in the sample.

UJ flag = The analysis was performed, but the result is highly questionable. The analyte may or may not be present in the sample.

$\mathrm{J}$ flag $=$ The analysis was performed and the analyte was detected. Result is statistically positive at the $95 \%$ confidence interval and is less than the minimum detectable activity. Result is questionable. The analyte is considered to be in the sample; however, the result may not be accurate. 


\subsection{CPP-03 Chronology of Events}

Table 2-3 presents a chronology of events for the CPP-03 project.

Table 2-3. Chronology of events for the CPP-03 project.

\begin{tabular}{ll}
\hline \multicolumn{1}{c}{ Date } & \multicolumn{1}{c}{ Event } \\
\hline October 1999 & Signed final ROD for INTEC (DOE-ID 1999). \\
February 2004 & Finalized and transmitted RD/RA Work Plan (DOE-ID 2004a). \\
May 2005 & Received approval of waste stream profile No. 4529Q at ICDF. \\
October 2005 & Approved FSP (DOE-ID 2005a). \\
June-July 2006 & Performed characterization sampling. \\
August 2006 & Mobilized equipment to the site. \\
August 29, 2006 & Began excavation. \\
September 11, 2006 & Uncovered empty drum in excavation. \\
December 11, 2006 & Completed excavation. \\
December 12, 2006 & Completed confirmation sampling. \\
December 12, 2006 & Completed disposal of excavated soil. \\
December 12, 2006 & Decontaminated excavator bucket. \\
December 14, 2006 & Submitted draft New Site Identification form for CPP-130. \\
December 2006 & Placed soil cover over the site and contoured excavation edges. \\
December 2006 & Demobilized equipment from the site. \\
February 15, 2007 & Transmitted prefinal/final inspection report (Butler 2007). \\
\hline
\end{tabular}

\subsection{Performance Standards and Construction Quality Control}

The OU 3-13 CPP-03 FSP was developed to guide sampling for the site (DOE-ID 2005a). The FSP was implemented with the latest revision of the Quality Assurance Project Plan for Waste Area Groups 1, 2, 3, 4, 5, 6, 7, 10 and Deactivation, Decontamination, and Decommissioning (DOE-ID 2004c), which provides guidance for sampling, quality assurance (QA), quality control (QC), analytical procedures, and data management. Together, the Quality Assurance Project Plan (QAPjP) (DOE-ID 2004c) and the FSP constitute the RA sampling and analysis plan (SAP).

The QAPjP and FSP were prepared in accordance with Guidance for Conducting Remedial Investigations and Feasibility Studies Under CERCLA (EPA 1988), the FFA/CO, and ICP policies and procedures.

\subsection{CPP-03 Final Inspection and Certification}

The CPP-03 Prefinal/Final Inspection Report (Butler 2007) was sent to the Agencies on February 15, 2007. The report noted two deficiencies from the original prefinal inspection checklist:

1. Submittal of the final results from confirmation sampling

2. Final contouring of the storm water drainage ditches, which were modified during remediation and not recontoured because of freezing conditions. 
Two copies of closure reports for the confirmation sampling were attached to the transmittal, thus completing the first deficiency. A note on the second deficiency indicated that it was a primary task and would be completed when conditions permit and would be tracked through completion in Fiscal Year (FY) 2007.

\subsection{Site Contact Information}

Table 2-4 provides contacts for the CPP-03 project.

Table 2-4. Contact information for the CPP-03 project.

\begin{tabular}{ll}
\multicolumn{1}{c}{ Title } & \multicolumn{1}{c}{ Name } \\
\hline DOE-ID WAG 3 project manager & Nicole Hernandez \\
Primary contractor Environmental Restoration facility manager & Marty Doornbos \\
Primary contractor Environmental Restoration project manager & Lee Davison \\
Primary contractor subcontractor technical representative & Jody Landis \\
Primary contractor ICDF project manager & Jack Simonds \\
DEQ INL Site representative & Ted Livieratos \\
EPA INL Site representative & Diane Thangamani \\
\hline
\end{tabular}


2-14 


\section{CPP-34A/34B, SOIL STORAGE AREAS (DISPOSAL TRENCHES) IN NORTHEAST CORNER OF INTEC}

\subsection{Site Background}

Site CPP-34 comprised the soil storage area in the northeast corner of INTEC. In the summer of 1983, approximately $9,180 \mathrm{~m}^{3}\left(12,000 \mathrm{yd}^{3}\right)$ of contaminated soil were excavated from around the Tank WL-102, in the tank farm area northeast of Building CPP-604, and stockpiled at Site CPP-03, to the east of Building CPP-603. In August and September 1984, the pile of contaminated soil was removed from CPP-03 and buried in three trenches in the northeastern corner of the ICPP (i.e., INTEC), situated between the animal (outer) and security (inner) fences. Because this site was associated with releases from the tank farm and the Waste Calcining Facility, condensate I-129 may have been present at very low concentrations.

Trenches were $13.7 \mathrm{~m}(45 \mathrm{ft})$ wide at the top, $7.6 \mathrm{~m}(25 \mathrm{ft})$ wide at the bottom, and approximately 4.3 to $4.9 \mathrm{~m}$ (14 to $16 \mathrm{ft})$ deep, and trenches were $126 \mathrm{~m}(413 \mathrm{ft}), 122 \mathrm{~m}(400 \mathrm{ft})$, and $74 \mathrm{~m}(242 \mathrm{ft})$ long. Track 1 (WINCO 1993) reported that, at the time of disposal, contaminated soil in the trenches was covered with approximately $0.6 \mathrm{~m}(2 \mathrm{ft})$ of clean soil.

The extent of Site CPP-34A/34B was known because boundaries of the trenches were well defined, based on documented process knowledge and analytical data. Previous sampling of contaminated soil at CPP-34A/34B had been performed, and sample results were detailed in the Group $3 \mathrm{RD} / \mathrm{RA}$ Work Plan (DOE-ID 2004a). Based on results of those investigations, soil contamination in CPP-34A/34B exceeded remediation goals for $\mathrm{Cs}-137$ and $\mathrm{Sr}-90$ for at least one depth at all four sample locations. Existing data were sufficient to complete a waste profile. Iodine- 129 was not detected in any of the characterization samples, and process knowledge from FY 2004 sampling of tank farm alluvium (collected every $4 \mathrm{ft}$ to basalt in Sites CPP-15, CPP-27, CPP-28, CPP-31, and CPP-79 and provided in DOE-NE-ID 2006) indicated no detectable presence of I-129. Consequently, only verification sampling was performed, per the Characterization Plan (DOE-ID 2004d). Verification sampling was performed as part of the waste disposal process.

The selected remedy for Site CPP-34A/34B addressed removal of contaminated soil and disposal in ICDF (DOE-ID 1999). No planned future land use or operation and maintenance requirements have been identified for these sites.

\subsubsection{Summary of Remedial Design}

This section outlines activities designed for excavation of contaminated soil associated with Site CPP-34A/34B. To implement the remedial action objective (RAO) strategy, the RD called for

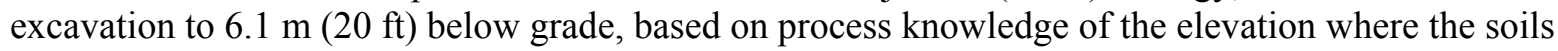
were buried.

Remedial design called for the following:

- Rerouting existing roads and surface features; activities will be limited primarily to protecting utilities while modifying surface features.

- Excavating contaminated soil in CPP-34A/34B to a depth of $6.1 \mathrm{~m}(20 \mathrm{ft})$ for a total estimated volume of $46,599 \mathrm{~m}^{3}\left(60,949 \mathrm{yd}^{3}\right)$.

- Importing backfill for the CPP-34A/34B area.

- Revegetating the laydown area at CPP-34A/34B. 
The FSP described the confirmation soil sampling strategy in detail (DOE-ID 2004b). Following remediation of the site, an initial radiological survey was performed for Cs-137 using an HPGe detector, followed by hot-spot removal, as necessary, and a resurvey, in accordance with the RD/RA Work Plan. The final HPGe survey of the excavated surface is provided in Appendix B (HPGe data results for CPP-34A/34B).

\subsection{Remediation and Demolition Activities}

Remediation and demolition activities followed the scope of work provided to ICDF project management and were based on the OU 3-13 site areas excavation (per the general sequencing plan) as outlined in the RD/RA Work Plan (DOE-ID 2004a). No construction interface documents were issued changing the scope of the work regarding the work plan and actual construction.

\subsubsection{Site Mobilization and Infrastructure Establishment}

Subcontractor mobilization began in May 2005. Work on improving the infrastructure was started first and included the following activities:

- Construct a controlled-access haul road between INTEC and ICDF

- Install a temporary scale to track quantities of soil removed

- Install a dust-control system that used water

- Identify fencing around the northeastern corner of INTEC that requires removal and protection prior to excavation activities

- Install soil ramps in CPP-34A/34B areas.

\subsubsection{Excavation}

Excavation activities at CPP-34A/34B began in May 2005. Excavation began first in CPP-34A. Work took place May 4 through November 7, 2005; soil was removed to a depth of approximately $6.4 \mathrm{~m}$ $(21 \mathrm{ft})$ from the soil contamination area. Total volume removed and transported from CPP-34A/34B to ICDF was approximately $46,090 \mathrm{~m}^{3}\left(60,283 \mathrm{yd}^{3}\right)$.

3.2.2.1 High-Purity Germanium Results and Maps. Field gamma gross radiation measurements at the CPP-34A/34B areas were taken during excavation. Figure 3-1 contains a diagram of the site showing plotted measurement locations. A Trimble Global Positioning System with survey-grade positioning was used to establish a grid.

The system used for data collection consisted of a $42 \%$ efficient (relative to $3 \times 3$ sodium iodide) HPGe detector mounted on a tripod with the detector face positioned $1 \mathrm{~m}(3.3 \mathrm{ft})$ above ground. This

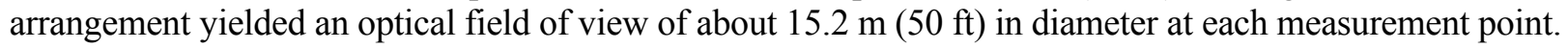
The detector was QC-checked daily using a multinuclide point source traceable to the National Institute of Standards and Technology. Results from these checks were control-charted daily, and all values were within control limits for the duration of the project. Count times were for 20 to 30 minutes, which gave precisions on the reported Cs- 137 concentration values that are less than $10 \%$ at the $2 \sigma$ confidence level. Spectral data were analyzed. Both the ISO-Plus soil analysis program (AMT 2002) and the DOE M1 analysis protocol (DOE 1997) were used to calculate the final Cs-137 concentrations. The DOE M1 analysis protocol (DOE 1997) has been used extensively at the INL Site and other DOE sites. 


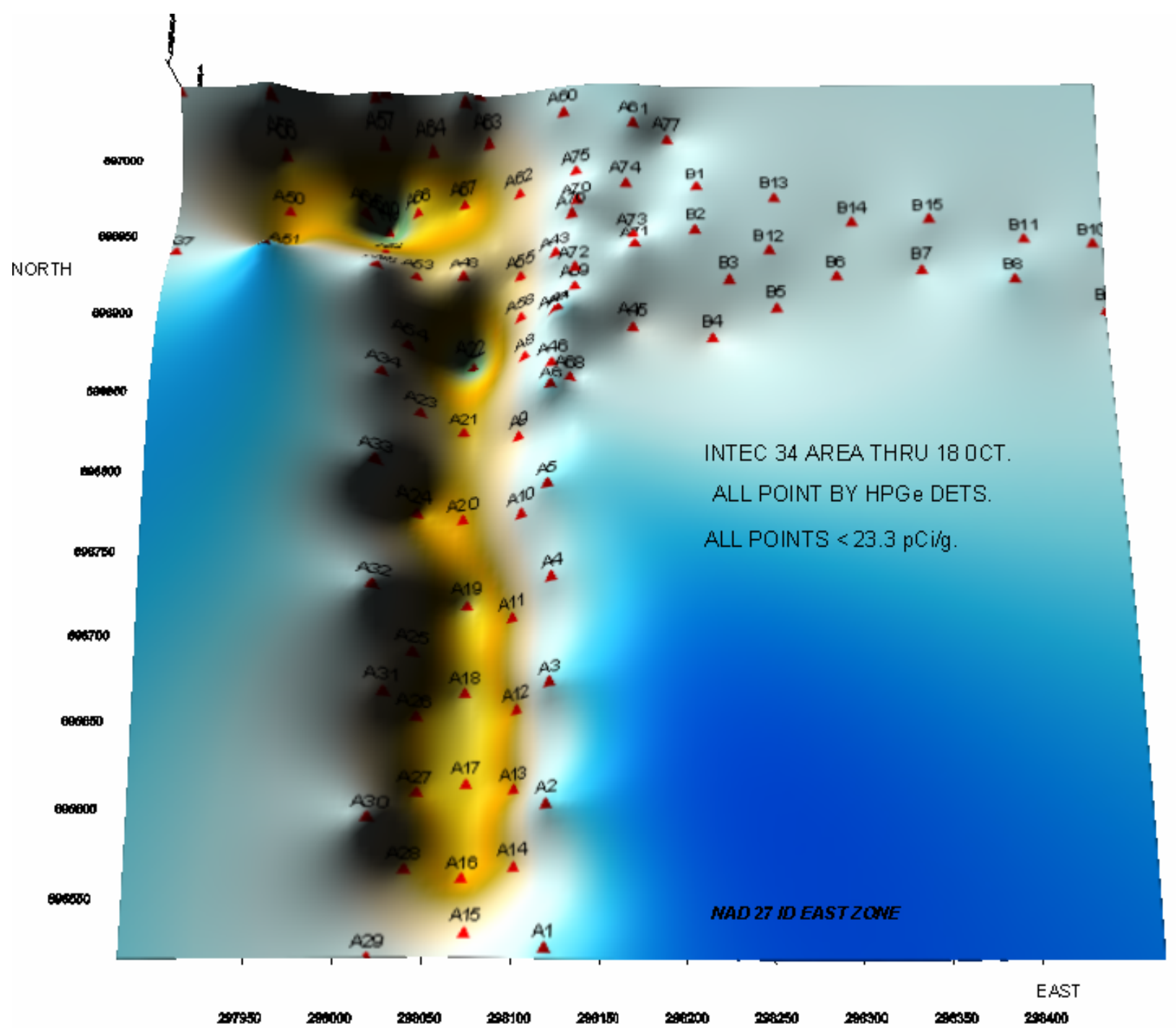

Figure 3-1. CPP-34A/34B high-purity germanium scans showing final excavation topography. Postexcavation locations are shown, all of which are below the remediation goal of $23 \mathrm{pCi} / \mathrm{g}$. Colors were used only to emphasize the contours and do not constitute radiological differences.

Results of the activity showed that nine locations exceeded the Cs-137 remediation goal of $23 \mathrm{pCi} / \mathrm{g}$. These areas were excavated, and radiation measurements were repeated. The pin flags were destroyed during this remediation, so the subsequent gamma scans were performed as physically close as possible to the initial measurement location. Tables B-1 and B-2 (see Appendix B) provide HPGe data and location differences. These measurements were all below the remediation goal for Cs-137 (23 pCi/g), meaning that remediation was complete and confirmation samples could be collected to verify the condition.

\subsubsection{Area Completion}

The finish plan called for approximately $35,187 \mathrm{~m}^{3}\left(46,023 \mathrm{yd}^{3}\right)$ of backfill for CPP-34A and approximately $11,412 \mathrm{~m}^{3}\left(14,926 \mathrm{yd}^{3}\right)$ of backfill for CPP-34B. Revegetation was required outside the area of contamination in the subcontractor laydown yard. Additionally, the temporary perimeter road installed to route emergency traffic around INTEC was reconstructed and revegetated, as necessary, and delivered back to its original state. 


\subsection{Chronology of Events}

Table 3-1 presents a chronology of events for the CPP-34A/34B project.

Table 3-1. Chronology of events for the CPP-34A/34B project.

\begin{tabular}{|c|c|}
\hline Date & Event \\
\hline October 1999 & Signed final ROD for INTEC (DOE-ID 1999). \\
\hline February 2004 & Finalized and transmitted RD/RA Work Plan (DOE-ID 2004a). \\
\hline March 2005 & Performed verification soil sampling at CPP-34A/34B. \\
\hline May 2005 & $\begin{array}{l}\text { Approved waste stream profile number } 4529 \mathrm{Q} \text { at ICDF (this profile is the } \\
\text { same as CPP-34A/34B since the primary source of contamination at } \\
\text { CPP-03 was due to the interim stockpiling of tank farm soils later buried at } \\
\text { CPP-34A/34B). }\end{array}$ \\
\hline May 2005 & $\begin{array}{l}\text { Began mobilization at CPP-34A/34B with establishment of infrastructure } \\
\text { improvements (e.g., build controlled access haul road from INTEC to } \\
\text { ICDF, remove animal fence, and install dust-suppression system). }\end{array}$ \\
\hline May 24, 2005 & Began to stockpile soil at the CPP-34A site. \\
\hline May 26, 2005 & Began first day of hauling soil to ICDF. \\
\hline May 31, 2005 & $\begin{array}{l}\text { Began to stockpile soil from the CPP-34B area and add this soil to working } \\
\text { stockpile in the CPP-34A area. }\end{array}$ \\
\hline July 14, 2005 & Began gamma scans (i.e., HPGe) of the CPP-34A area in northwest corner. \\
\hline August 9, 2005 & Began collecting confirmation soil samples at CPP-34A. \\
\hline August 16, 2005 & $\begin{array}{l}\text { Began decontamination of heavy equipment and scaled-back truck-hauling } \\
\text { operation from eight to six articulated trucks. }\end{array}$ \\
\hline August 22, 2005 & $\begin{array}{l}\text { Completed removing contaminated soil in CPP-34B. Samplers completed } \\
\text { collecting confirmation soil samples in CPP-34B. Additionally, crew } \\
\text { began backfilling the CPP-34B excavation. }\end{array}$ \\
\hline September 26, 2005 & $\begin{array}{l}\text { Completed backfill of CPP-34B. Samplers completed confirmation } \\
\text { sampling in south end of CPP-34A. Also began backfilling south end of } \\
\text { CPP-34A. Crew continued to excavate soil in northeast corner of } \\
\text { CPP-34A. }\end{array}$ \\
\hline October 5, 2005 & $\begin{array}{l}\text { Completed the confirmation sampling at CPP-34A and began to backfill } \\
\text { entire CPP-34A area. }\end{array}$ \\
\hline October 18, 2005 & Completed field gamma gross radiation (i.e., HPGe) measurements. \\
\hline October 25, 2005 & Began revegetation of CPP-34A/34B laydown area. \\
\hline October 26,2005 & Completed the backfill of CPP-34A. \\
\hline November 16 and 17, 2005 & $\begin{array}{l}\text { Conducted site tour for CPP-34A/34B areas for DEQ, EPA, DOE, and } \\
\text { Bechtel BWXT Idaho, LLC (BBWI) representatives. }\end{array}$ \\
\hline December 8, 2005 & $\begin{array}{l}\text { Transmitted prefinal inspection letter indicating no final inspection was } \\
\text { necessary (Butler 2005). }\end{array}$ \\
\hline
\end{tabular}




\subsection{Performance Standards and Construction Quality Control}

The OU 3-13 Phase I FSP was developed to guide sampling (DOE-ID 2004b). The FSP was implemented using the latest revision of the QAPjP, which provides guidance for sampling, QA, QC, analytical procedures, and data management. Together, the QAPjP and the FSP constitute the RA SAP.

The RAO for the CPP-34A/34B site, as stated in the RD/RA Work Plan (DOE-ID 2004a), was to prevent exposure to contaminated surface soil such that for all surface exposure pathways, a cumulative carcinogenic risk of $1 \times 10^{-4}$ and a total hazard index of 1 was not exceeded. To meet this RAO, remediation goals were established in the OU 3-13 ROD (DOE-ID 1999, p. 8-4) to ensure a risk-based protectiveness of human health and the environment. Table 3-2 compares project performance results from confirmation sampling to remediation goals and shows that the RAO was achieved.

Table 3-2. Comparison between risk-based remediation goals and performance levels achieved for CPP-34A/34B soils.

\begin{tabular}{ccc}
\hline $\begin{array}{c}\text { Contaminant } \\
\text { of Concern }\end{array}$ & $\begin{array}{c}\text { Soil Risk-Based Remediation Goal for } \\
\text { Single Contaminants of Concern } \\
(\mathrm{pCi} / \mathrm{g})\end{array}$ & $\begin{array}{c}\text { Performance Level } \\
\text { Achieved }^{\mathrm{a}} \text { 95\% UCL } \\
(\mathrm{pCi} /)\end{array}$ \\
\hline Cs-137 & 23 & 1.5 \\
Sr-90 & 223 & 1.5 \\
\hline a. Performance level results are from confirmation sampling data presented in Kirchner (2005b). \\
\hline
\end{tabular}

\subsubsection{Sampling Activities and Results}

Soil sampling was performed during two activities. Verification and confirmation soil sampling was performed by the Environmental Services project under ESP-014-05 (Kirchner 2005a) and ESP-050-05 (Kirchner 2005b), respectively. Verification sampling results were compared to the ICDF landfill Waste Acceptance Criteria (WAC), as described in the Characterization Plan (DOE-ID 2004d). Confirmation sampling was compared to remediation goals to assess RA performance, as described in the OU 3-13 Phase I FSP (DOE-ID 2004b). Between these activities, during excavation, field surveys were used to locate hot spots and guide excavation, as described in Section 3.2.2.

3.4.1.1 ESP-014-05 Sampling Activity (Verification Sampling). Initial verification soil samples were collected from CPP-34A/34B following Plan (PLN) -1901. These samples were collected for I-129 characterization and inorganic verification sampling for material profile $4529 \mathrm{q}-\mathrm{CPP}-34 \mathrm{~A} / 34 \mathrm{~B}$ trenches (ESP-014-05) (Kirchner 2005a). In March 2005, soil samples were taken from CPP-34A/34B, at depths ranging from 0.3 to $6.1 \mathrm{~m}$ ( 1 to $20 \mathrm{ft})$. Verification sample results validated the original characterization data for CPP-34A/34B.

3.4.1.2 ESP-050-05 Sampling Activity (Confirmation Sampling). Samples were collected in August through September 2005. These samples were collected to confirm the Cs-137 and Sr-90 remediation goals were met. The data presented in ESP-050-05 (Kirchner 2005b) is reproduced below in Tables 3-3 and 3-4. 
Table 3-3. Confirmation sampling data summary of Cs-137 for Site CPP-34A/34B.

\begin{tabular}{|c|c|c|c|c|c|}
\hline Sample & $\begin{array}{l}\text { Cs-137 } \\
\text { Activity }^{\mathrm{a}} \\
(\mathrm{pCi} / \mathrm{g})\end{array}$ & $\begin{array}{l}\text { Cs-137 } \\
\text { Activity } \\
\text { (pCi/g) }\end{array}$ & $\begin{array}{c}\text { Validation } \\
\text { Flag }^{\mathrm{c}}\end{array}$ & $\begin{array}{c}\text { Sample } \\
\text { Uncertainty }\end{array}$ & $\begin{array}{l}\mathrm{MDA}^{\mathrm{d}} \\
(\mathrm{pCi} / \mathrm{g})\end{array}$ \\
\hline VS34A-1 & $5.11 \mathrm{E}-01$ & $5.11 \mathrm{E}-01$ & & $6.60 \mathrm{E}-02$ & $1.10 \mathrm{E}-01$ \\
\hline VS34A-2 & $1.22 \mathrm{E}-01$ & $1.22 \mathrm{E}-01$ & & $3.50 \mathrm{E}-02$ & $1.00 \mathrm{E}-01$ \\
\hline VS34A-3 & $-6.00 \mathrm{E}-04$ & $0.00 \mathrm{E}-01$ & $\mathrm{U}$ & $2.60 \mathrm{E}-02$ & $9.40 \mathrm{E}-02$ \\
\hline VS34A-4 & $2.16 \mathrm{E}+00$ & $2.16 \mathrm{E}+00$ & & $1.70 \mathrm{E}-01$ & $1.20 \mathrm{E}-01$ \\
\hline VS34A-5 & $2.06 \mathrm{E}+00$ & $2.06 \mathrm{E}+00$ & & $1.50 \mathrm{E}-01$ & $1.10 \mathrm{E}-01$ \\
\hline VS34A-6 & $1.44 \mathrm{E}+00$ & $1.44 \mathrm{E}+00$ & & $1.10 \mathrm{E}-01$ & $9.00 \mathrm{E}-02$ \\
\hline VS34B-1 & $1.33 \mathrm{E}-01$ & $2.35 \mathrm{E}-01$ & & $2.50 \mathrm{E}-02$ & $6.30 \mathrm{E}-02$ \\
\hline VS34B-1 Dup & $3.37 \mathrm{E}-01$ & & & $3.80 \mathrm{E}-01$ & $5.70 \mathrm{E}-02$ \\
\hline VS34B-2 & $6.40 \mathrm{E}-02$ & $6.40 \mathrm{E}-02$ & & $2.10 \mathrm{E}-02$ & $8.10 \mathrm{E}-02$ \\
\hline \multicolumn{6}{|c|}{ Data Summary ${ }^{\mathrm{e}}$} \\
\hline \multicolumn{3}{|c|}{ Maximum value } & \multicolumn{2}{|c|}{2.16} & \\
\hline & \multicolumn{2}{|c|}{ Average } & \multicolumn{2}{|c|}{0.82} & \\
\hline & \multicolumn{2}{|c|}{ Standard deviation } & \multicolumn{2}{|c|}{0.92} & \\
\hline & \multicolumn{2}{|c|}{ Confidence interval } & \multicolumn{2}{|c|}{0.68} & \\
\hline & \multicolumn{2}{|c|}{$95 \%$ upper confidence level } & \multicolumn{2}{|c|}{1.50} & \\
\hline
\end{tabular}

a. Column contains the complete data set.

b. Data used for the statistical evaluation. VS34B-1 and the duplicate were averaged. VS34A-3 was not used.

c. No flag $=$ The analysis was performed and radioactivity was detected (statistically positive at the $95 \%$ confidence interval and is above the minimum detectable activity). The radionuclide is considered to be present in the sample.

$\mathrm{U}$ flag $=$ Material analyzed for and not detected.

d. MDA = minimum detectable activity.

e. Calculations performed as shown in Section 2.2.4.

Table 3-4. Confirmation sampling data summary of total strontium for Site CPP-34A/34B.

\begin{tabular}{lccccc}
\hline Sample & $\begin{array}{c}\text { Total Strontium } \\
\text { Activity }^{\mathrm{a}} \\
(\mathrm{pCi} / \mathrm{g})\end{array}$ & $\begin{array}{c}\text { Total Strontium } \\
\text { Activity }^{\mathrm{b}} \\
(\mathrm{pCi} / \mathrm{g})\end{array}$ & $\begin{array}{c}\text { Validation } \\
\text { Flag }^{\mathrm{c}}\end{array}$ & $\begin{array}{c}\text { Sample } \\
\text { Uncertainty }^{\mathrm{d}}\end{array}$ & $\begin{array}{c}\mathrm{MDA}^{\mathrm{d}} \\
(\mathrm{pCi} / \mathrm{g})\end{array}$ \\
\hline VS34A-1 & $2.85 \mathrm{E}+00$ & $2.85 \mathrm{E}+00$ & $\mathrm{~J}$ & $1.60 \mathrm{E}-01$ & $1.80 \mathrm{E}-01$ \\
VS34A-2 & $4.78 \mathrm{E}-01$ & $4.78 \mathrm{E}-01$ & $\mathrm{~J}$ & $6.80 \mathrm{E}-02$ & $2.00 \mathrm{E}-01$ \\
VS34A-3 & $2.02 \mathrm{E}-01$ & $2.02 \mathrm{E}-01$ & & $6.50 \mathrm{E}-02$ & $2.00 \mathrm{E}-01$ \\
VS34A-4 & $8.46 \mathrm{E}-01$ & $8.46 \mathrm{E}-01$ & & $8.90 \mathrm{E}-02$ & $2.10 \mathrm{E}-01$ \\
VS34A-5 & $8.27 \mathrm{E}-01$ & $8.27 \mathrm{E}-01$ & & $8.60 \mathrm{E}-02$ & $2.00 \mathrm{E}-01$ \\
VS34A-6 & $9.80 \mathrm{E}-01$ & $9.80 \mathrm{E}-01$ & & $1.00 \mathrm{E}-01$ & $2.40 \mathrm{E}-01$ \\
VS34B-1 & $1.60 \mathrm{E}-01$ & $0.00 \mathrm{E}+00$ & $\mathrm{U}$ & $2.50 \mathrm{E}-01$ & $4.10 \mathrm{E}-01$ \\
VS34B-1 Dup & $3.60 \mathrm{E}-01$ & & $\mathrm{U}$ & $2.60 \mathrm{E}-01$ & $4.10 \mathrm{E}-01$ \\
VS34B-2 & $2.00 \mathrm{E}-02$ & $0.00 \mathrm{E}+00$ & $\mathrm{U}$ & $2.50 \mathrm{E}-01$ & $4.20 \mathrm{E}-01$ \\
\hline
\end{tabular}


Table 3-4. (continued).

\begin{tabular}{|c|c|c|c|c|c|}
\hline Sample & $\begin{array}{c}\text { Total Strontium } \\
\text { Activity }^{\mathrm{a}} \\
(\mathrm{pCi} / \mathrm{g})\end{array}$ & $\begin{array}{c}\text { Total Strontium } \\
\text { Activity } \\
(\mathrm{pCi} / \mathrm{g})\end{array}$ & $\begin{array}{c}\text { Validation } \\
\text { Flag }^{\mathrm{c}}\end{array}$ & $\begin{array}{c}\text { Sample } \\
\text { Uncertainty }\end{array}$ & $\begin{array}{l}\mathrm{MDA}^{\mathrm{d}} \\
(\mathrm{pCi} / \mathrm{g})\end{array}$ \\
\hline \multicolumn{6}{|c|}{ Data Summary ${ }^{\mathrm{e}}$} \\
\hline \multicolumn{3}{|c|}{ Maximum value } & 2.85 & & \\
\hline \multicolumn{3}{|c|}{ Average } & 0.77 & & \\
\hline \multicolumn{3}{|c|}{ Standard deviation } & 0.92 & & \\
\hline \multicolumn{3}{|c|}{ Confidence interval } & 0.68 & & \\
\hline \multicolumn{3}{|c|}{$95 \%$ UCL } & 1.45 & & \\
\hline
\end{tabular}

a. Column contains the complete data set.

b. Data used for the statistical evaluation. VS34B-1 and the duplicate were averaged. VS34A-3 was not used.

c. No flag $=$ The analysis was performed and radioactivity was detected (statistically positive at the $95 \%$ confidence interval

and is above the minimum detectable activity). The radionuclide is considered to be present in the sample.

$\mathrm{J}$ flag $=$ The analysis was performed and the analyte was detected. Result is statistically positive at the $95 \%$ confidence interval and is less than the minimum detectable activity. Result is questionable. The analyte is considered to be in the sample; however, the result may not be accurate.

$\mathrm{U}$ flag = Material analyzed for and not detected.

d. MDA = minimum detectable activity.

e. Calculations performed as shown in Section 2.2.4.

Confirmation samples collected at Site CPP-34A/34B after remediation showed the 95\% UCL for the average residual concentration for $\mathrm{Cs}-137$ to be $1.5 \mathrm{pCi} / \mathrm{g}$. This value is substantially lower than the remediation goal of $23 \mathrm{pCi} / \mathrm{g}$.

Confirmation samples collected at Site CPP-34A/34B after remediation showed the 95\% UCL for the average residual concentration for total strontium to be $1.5 \mathrm{pCi} / \mathrm{g}$. This value is also substantially lower than the remediation goal of $223 \mathrm{pCi} / \mathrm{g}$.

Based on the above results, remediation of Site CPP-34A/34B is complete.

\subsection{Final Inspection and Certification}

The prefinal inspection report (Butler 2005) documents findings from the prefinal inspection checklist. Because no open items were found, Butler (2005) serves as the final inspection for Site CPP-34A/34B.

\subsection{Site Contact Information}

Table 3-5 provides contact information for the CPP-34A/34B project.

Table 3-5. Contact information for the CPP-34A/34B project.

\begin{tabular}{ll}
\hline \multicolumn{1}{c}{ Title } & \multicolumn{1}{c}{ Name } \\
\hline DOE-ID INL Site representative & Mary Verwolf \\
Primary contractor Environmental Restoration facility manager & Marty Doornbos \\
Primary contractor Environmental Restoration project manager & Lee Davison \\
Primary contractor subcontractor technical representative & Jody Landis \\
Primary contractor ICDF project manager & Jack Simonds \\
DEQ INL Site representative & Ted Livieratos \\
EPA INL Site representative & Dennis Faulk/Diane Thangamani \\
\hline
\end{tabular}




\section{CPP-37A, GRAVEL PIT OUTSIDE INTEC FENCE}

\subsection{Site Background}

Site CPP-37A consisted of Gravel Pit \#1, which is located outside the INTEC security fence in the northeast corner (see Figure 1-2) and measured approximately $43 \mathrm{~m}$ (140 ft) wide, $64 \mathrm{~m} \mathrm{(210} \mathrm{ft)} \mathrm{long,} \mathrm{and}$ $4.3 \mathrm{~m}$ (14 ft) deep. No information was available on the date pit use began; however, Pit \#1 was used for decontamination of radiologically contaminated construction equipment during July and October 1983. In addition, during 1982 and 1983, Pit \#1 was used as a percolation pond for INTEC service wastewater while the injection well was being refitted. This pit received storm water runoff from INTEC until August 2003. The extent of Site CPP-37A is known because physical boundaries of the pit are well defined, and use and disposal practices at this site are well documented.

In 1991, soil samples were collected from several boreholes in Pit \#1 (GAI 1992; LITCO 1995). One deeper borehole was drilled in the center of Pit \#1 from which soil samples were collected at 1.5-m

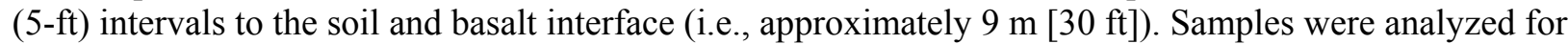
inorganics, volatile organic compounds (VOCs), semivolatile organic compounds (SVOCs), pesticides and herbicides, polychlorinated biphenyls (PCBs), and radionuclides. The data, summarized in Appendix A of the RD/RA Work Plan (DOE-ID 2004a), indicate that arsenic was detected above background values (Rood, Harris, and White 1995) in several samples. However, the maximum arsenic concentration was only $8.7 \mathrm{mg} / \mathrm{kg}$, relative to the background value for arsenic of $5.8 \mathrm{mg} / \mathrm{kg}$. Radionuclides detected above background in soil samples collected in Pit \#1 were Am-241, Cs-137, $\mathrm{Np}-237, \mathrm{Pu}-238$, and Sr-90. Iodine-129 was analyzed for, but not detected in any sample. Other radionuclides that do not have a background value were detected at low concentrations, including Co-60, $\mathrm{U}-235$, and U-238. No radionuclides were detected in the 0 to $0.3-\mathrm{m}$ (0 to 0.5 - $\mathrm{ft})$ samples, except for $\mathrm{Sr}-90$ at $0.69 \pm 0.12 \mathrm{pCi} / \mathrm{g}$ in the southwestern portion of the pit. Radionuclides were not detected above background in the deep borehole below $4.6 \mathrm{~m}$ (15 ft).

No remediation goals were exceeded for any sample at CPP-37A. Europium-152, Eu-154, and $\mathrm{Pu}-241$ are $\mathrm{COC}$ constituents that were not analyzed for during past sampling. Using Cs-137 as a scaling factor, as described in Section 3.3 of the Engineering Design File (EDF) for the ICDF Design Inventory (EDF-ER-264), 95\% UCL estimates for these values were developed. A comparison of the estimated 95\% UCL values to remediation goals for Group 3 COCs, including Eu-152, Eu-154, and Pu-241, is shown in Table 3-1 of the RD/RA Work Plan. This comparison illustrates that even if concentration estimates were significantly higher than reasonably expected (several orders of magnitude), values would still fall below remediation goals.

There are no planned future uses for Site 37A.

\subsubsection{Summary of Remedial Design}

Section 13.2 of the OU 3-13 ROD (DOE-ID 1999), "Sites Included in Other Programs or Other OUs," identified that for Site CPP-37A, "A presumptive remedy of excavate and dispose at the ICDF will be implemented." This decision was based on available data at the time of development of the OU 3-13 ROD. Data at that time were not complete because they did not include Eu-152, Eu-154, and Pu-241 COCs. Using a Cs-137 scaling factor, it is now possible to provide information on these COCs. In review of this new information, COCs at Site CPP-37A do not exceed OU 3-13 remediation goals. The presumptive remedy of excavate and manage at ICDF is not needed because the cleanup levels are currently met. 


\subsection{Remediation Activities}

No remediation was conducted on Site CPP-37A. Hazardous constituents identified through sampling do not exist in sufficient concentration or activity to warrant remediation. This site is now considered a No Further Action site.

\subsection{Chronology of Events}

Table 4-1 presents a chronology of events for the CPP-37A project.

Table 4-1. Chronology of events for the CPP-37A project.

\begin{tabular}{ll}
\hline \multicolumn{1}{c}{ Date } & \multicolumn{1}{c}{ Event } \\
\hline October 7, 1999 & Signed final ROD for INTEC (DOE-ID 1999). \\
February 2004 & Finalized and transmitted RD/RA Work Plan (DOE-ID 2004a). \\
\hline
\end{tabular}




\section{CPP-37B, GRAVEL PIT AND DEBRIS LANDFILL INSIDE INTEC FENCE}

\subsection{Site Background}

Site CPP-37B consisted of Gravel Pit \#2, located in the northeast corner inside the INTEC security fence (see Figure 1-2). Before being backfilled, Gravel Pit \#2 was approximately $79 \mathrm{~m}(260 \mathrm{ft})$ wide,

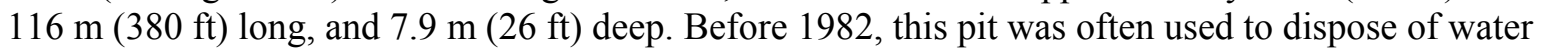
released from the sludge dewatering pit of the old Sewage Treatment Plant (CPP-715). The exact volume of water effluent discharged to this gravel pit is unknown, but the volume is believed to be low. Sludge from the dewatering pit was known to be radioactively contaminated, indicating that water discharged to the pit likely contained radionuclides.

After 1982, the pit was used to dispose of construction debris, some of which may have been radioactively contaminated. Anecdotal information suggests that Gravel Pit \#2 may also have been used for disposal of chemical waste. Additionally, the pit was open in 1964 when the release of radioactive steam associated with Site CPP-26 occurred. Radioactive steam containing Cs-137 was released from a decontamination header in the high-level liquid waste tank farm. The specific date this pit was backfilled is unknown, but it is believed to have been backfilled to grade shortly after its use as a construction debris landfill was discontinued.

The physical boundary of Gravel Pit \#2, shown in the OU 3-13 ROD (DOE-ID 1999), was based on historical knowledge, the 1980 topographical survey (GAI 1992), and the 1991 geophysical survey. However, when reviewing CERCLA documents and aerial photos related to Site CPP-37C, it was determined that the CPP-37B boundary identified in the OU 3-13 ROD does not accurately reflect the full extent of the excavation pit used for disposal. Thus, the boundary of Site CPP-37B was expanded to include outer limits of the pit area.

The selected remedy for Site CPP-37B, as developed in the OU 3-13 ROD, was to further characterize the site and determine whether remediation is required, and if so, to develop a path forward.

There is no planned future use for Site 37B.

\subsubsection{Summary of Remedial Design}

Previous investigations of contamination at Site CPP-37B included a geophysical survey and samples collected from four boreholes (i.e., CPP-37-1, -2, -3, and -4) in Gravel Pit \#2 in 1991 (GAI 1992; LITCO 1995). Samples were analyzed for inorganics, VOCs, SVOCs, pesticides and herbicides, PCBs, and radionuclides. Data, summarized in Appendix A of the RD/RA Work Plan (DOE-ID 2004a), indicate that arsenic, barium, chromium, mercury, and silver were detected above background concentrations (Rood, Harris, and White 1995) in one sample from Borehole CPP-37-4. Silver also was detected above background concentrations in one sample from Borehole CPP-37-3. Analyses were performed for a limited number of organics; of those detected, none exceeded the ICDF WAC (DOE-ID 2005b). Radionuclides detected above background in soil samples collected in Pit \#2 were Am-241, Cs-137, $\mathrm{Pu}-238, \mathrm{Sr}-90$, and U-238. Other radionuclides that have no background value were detected, including I-129, Np-237, and U-235. Cesium-137, Np-237, and Sr-90 were detected most frequently in the samples from the four boreholes. Concentrations of Cs-137 and Sr-90 typically decrease with depth below the base of the fill (i.e., 6.4 to $7.9 \mathrm{~m}$ [21 to $26 \mathrm{ft}$ ]). Cesium- 137 was not detected above background values below

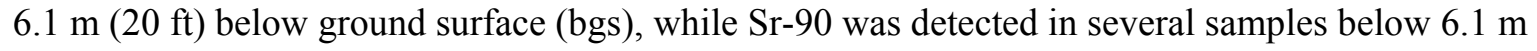
(20 ft) bgs. The presence of Sr-90 and not Cs-137 in deeper samples is likely due to the increased 
mobility of Sr-90 relative to Cs-137. In two of the four borings at Pit \#2, Sr-90 was the only radionuclide detected between a depth of $6.1 \mathrm{~m}(20 \mathrm{ft})$ and the top of basalt. No radionuclides were detected in the sample from the 33-m (109-ft) interbed beneath Gravel Pit \#2.

Based on these investigations, no remediation goals were exceeded for any sample result at CPP-37B; however, existing CPP-37B data were insufficient to determine, with statistical confidence, whether remediation goals were exceeded at this site. Also, previous sampling did not analyze for Eu-152 and Eu-154. Therefore, additional characterization data were needed to determine whether remediation of this site is necessary. Also, the suspected presence of contaminated debris at Site CPP-37B was unconfirmed.

In 2006, the final three-phase characterization effort for Site CPP-37B was designed to determine whether remediation was required and, if so, develop a path forward (DOE-ID 2005a). The first phase was a geophysical survey using a time-domain metal detector to (1) determine boundaries of the site, (2) determine extent and locations of debris and utilities, and (3) confirm the pit edges. The second phase comprised characterization sampling of six biased locations, designed to supplement previous sampling and to avoid boring into debris and utilities (using the results of Phase I). The third phase was excavating pits and trenches to extract buried debris (located in the first phase) for radiological field screening. Two pit locations were dug at Site CPP-37B. An HPGe detector was used during the excavation to monitor real-time radiation fields in the pit area and to characterize excavated soil and debris for Cs-137 contamination.

Results of the three-phase effort indicated that Site CPP-37B did not require RA (ICP 2006a). Geophysical survey information was used to verify physical boundaries and determine locations of debris and utilities. Based on this information, samples were collected and analyzed. Sample results were significantly below remediation goals for all COCs. Evaluation of excavated debris showed Cs-137 contamination to be at least one order of magnitude less than the remediation goal. The COCs contained in Site CPP-37B are well below action levels, supporting a determination that these sites be considered No Further Action sites.

\subsection{Remediation and Demolition Activities}

No remediation was conducted on Site CPP-37B. Hazardous constituents identified through sampling do not exist in sufficient concentration or activity to warrant remediation. Site CPP-37B is now considered a No Further Action site.

\subsection{Chronology of Events}

Table 5-1 presents a chronology of events for the CPP-37B project.

Table 5-1. Chronology of events for the CPP-37B project.

\begin{tabular}{ll}
\hline \multicolumn{1}{c}{ Date } & \multicolumn{1}{c}{ Event } \\
\hline October 7, 1999 & Signed final ROD for INTEC (DOE-ID 1999). \\
February 2004 & Finalized and transmitted RD/RA Work Plan (DOE-ID 2004a). \\
July and August 2005 & Performed geophysical survey. \\
September 2005 & Finalized Characterization Plan (DOE-ID 2004d). \\
October 11, 2005 & Completed sampling boreholes at CPP-37B. \\
November 2005 & Completed excavation of test pits and trenches. \\
May 2006 & Finalized characterization results report; determined Site CPP-37B to be a \\
& No Further Action site (ICP 2006a). \\
\hline
\end{tabular}




\subsection{Site Contact Information}

Table 5-2 provides contact information for the CPP-37B and CPP-37C projects.

Table 5-2. Contact information for the CPP-37B and CPP-37C projects.

\begin{tabular}{ll}
\multicolumn{1}{c}{ Title } & \multicolumn{1}{c}{ Name } \\
\hline DOE-ID INL WAG 3 project manager & Nicole Hernandez \\
Primary contractor Environmental Restoration facility manager & Marty Doornbos \\
Primary contractor Environmental Restoration project manager & Lee Davison \\
Primary contractor subcontractor technical representative & Bruce Birk \\
DEQ INL Site representative & Ted Livieratos \\
EPA INL Site representative & Dennis Faulk/Diane Thangamani \\
\hline
\end{tabular}




\section{CPP-37C, NEW SITE CONTAMINATION AREA SOUTHWEST OF CPP-37B}

\subsection{Site Background}

Site CPP-37C was not identified in the ROD (DOE-ID 1999). Rather, it was established in 2002 after contamination was discovered in November 2000, southeast of and adjacent to, Site CPP-37B (see Figure 1-2) while digging a trench along the fence near the east perimeter road (ICP 2002). This contamination included construction debris (mostly lava rock, gravel, and soil and minor amounts of concrete, plywood, pipe, and plastic) located approximately 1.5 to $1.8 \mathrm{~m} \mathrm{(5} \mathrm{to} 6 \mathrm{ft}) \mathrm{bgs}$ to below the bottom of the excavation (approximately $4.3 \mathrm{~m}$ [14 ft]) and appeared to be most prevalent on the west edge of the trench.

Physical boundaries for Site CPP-37C were defined using aerial photos and topographical surveys. The INL Site aerial photographs indicated that the CPP-37C site boundary is bounded on the east by the east perimeter road, on the south by the internal INTEC access roadway system, on the west by Site CPP-37B, and on the north by CPP-37B northern limits.

Data and process knowledge for Site CPP-37C were insufficient to define the extent of contamination or to determine whether remediation goals were exceeded. Therefore, characterization data were needed to determine if remediation of this site was necessary. Also, the suspected presence of contaminated debris at Site CPP-37C was unconfirmed.

\subsubsection{Summary of Remedial Design}

The final three-phase characterization effort for Site CPP-37C in 2006 (DOE-ID 2005a) was designed to determine whether remediation was required, and, if so, to develop a path forward. The first phase was a geophysical survey using a time-domain metal detector to (1) determine boundaries of the site, (2) determine extent and locations of debris and utilities, and (3) confirm the pit edges. The second phase comprised characterization sampling of 11 biased locations, based on results of the geophysical survey, historical photos, and historical survey data. The third phase comprised excavation of pits and trenches to extract buried debris (located in Phase I) for radiological field screening. One pit location was dug at CPP-37C. An HPGe detector was used during the excavation to monitor real-time radiation fields in the pit area and to characterize excavated soil and debris for Cs-137 contamination.

Results of this three-phase effort document that CPP-37C did not require RA (ICP 2006a). Geophysical survey information was used to verify physical boundaries and to determine locations of debris and utilities. Based on this, samples were collected and analyzed. Sample results were significantly below remediation goals for all COCs. Evaluation of excavated debris showed Cs-137 contamination to be at least one order of magnitude less than the remediation goal.

\subsection{Remediation and Demolition Activities}

No remediation was conducted on Site CPP-37C. Hazardous constituents identified through sampling, and remediation goals imposed thereon in the ROD for Group 3 sites, do not exist in sufficient concentration or activity to warrant remediation. This site is now considered a No Action site. 


\subsection{Chronology of Events}

Table 6-1 presents a chronology of events for the CPP-37C project.

Table 6-1. Chronology of events for the CPP-37C project.

\begin{tabular}{ll}
\hline \multicolumn{1}{c}{ Date } & \multicolumn{1}{c}{ Event } \\
\hline October 7, 1999 & Signed final ROD for INTEC (DOE-ID 1999). \\
September 2002 & Identified new site for CPP-37C. \\
February 2004 & Finalized and transmitted RD/RA Work Plan (DOE-ID 2004a). \\
July and August 2005 & Performed geophysical survey. \\
September 2005 & Finalized Characterization Plan (DOE-ID 2004d). \\
October 12, 2005 & Completed sampling boreholes at CPP-37C. \\
November 2005 & Completed excavation of test pits and trenches. \\
May 2006 & Finalized characterization results report; Site CPP-37C determined to be a \\
\hline
\end{tabular}

\subsection{Site Contact Information}

Table 5-2 provides contacts for the CPP-37C project. 


\section{CPP-67, PERCOLATION PONDS 1 AND 2}

A completion report was prepared for Site CPP-67, and Agency review comments were incorporated into the final version transmitted to the Agencies on July 21, 2005. The final report was titled Site Completion Report for Area CPP-67, WAG 3, OU 3-13, Group 3, Other Surface Soils (DOE-NE-ID 2005).

\subsection{Site Background}

Site CPP-67 consisted of two unlined service waste (percolation) ponds (SWPs) that received service wastewater consisting primarily of cooling water and condensed steam generated by various INTEC operations. The ponds were located just outside the INTEC fenced perimeter on the southern side (see Figure 1-2). INTEC wastewater, containing only traces of radioactivity (or none at all), passed through the service waste system. This waste was monitored for radioactivity before being discharged to SWP-1 or SWP-2. Three main service waste systems operated at the ICPP (now INTEC) discharging to the ponds: east-side system, west-side system, and CPP-604 process equipment waste process condensate monitoring and shutdown system. Under normal conditions, radioactivity was not present in any service waste streams except the process equipment waste evaporator overhead condensate, which routinely contained trace quantities of radionuclides. Therefore, because this site was associated with process equipment waste evaporator waste, I-129 was expected in the waste.

Pond SWP-1 (POND-YGD-326) was established in 1984 and is approximately $125 \mathrm{~m}$ (410 ft) long

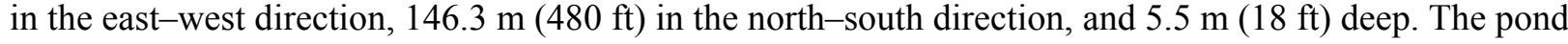
was excavated into gravelly alluvium that is approximately 7.6 to $9.1 \mathrm{~m}(25$ to $30 \mathrm{ft})$ thick and is underlain by basalt.

Pond SWP-2 (POND-YGD-327) was established in 1985 when it became apparent that the infiltration capacity of SWP-1 had decreased, and water levels began to rise. The pond bottom is approximately $152 \mathrm{~m}(500 \mathrm{ft})$ square and 3.7 to $4.3 \mathrm{~m}(12$ to $14 \mathrm{ft})$ deep. The pond was excavated in gravelly alluvium approximately 6 to $11 \mathrm{~m}$ (20 to $35 \mathrm{ft})$ thick and underlain with basalt. The pond was designed to accommodate continuous disposal of approximately 11.4 million L (3 million gal) of water per day.

Resource Conservation and Recovery Act clean-closure equivalency was achieved for metals contamination in Pond SWP-1 in April 1994 and Pond SWP-2 in May 1995; therefore, only radionuclide contamination was assessed as part of the WAG 3 remedial investigation and baseline risk assessment. Site CPP-67 was considered to be a significant source of perched water beneath the southern portion of the INTEC facility and a source of contaminants to the aquifer (DOE-ID 1999). Ponds SWP-1 and SWP-2 were taken out of service in August 2002. DOE-ID (2004a) provides further information about process knowledge and previous investigations.

The extent of Site CPP-67 is known because the boundaries of the ponds are well-defined, based on documented process knowledge and analytical data.

\subsubsection{Summary of Remedial Design}

The selected remedy for Site CPP-67 comprises removal of contaminated soil and disposal to ICDF (DOE-ID 1999). Once this has been finished and remedial activities completed, permanent land use restrictions will be placed on Site CPP-67 and the ICDF Complex, which will be closed in place, for as long as land use and access restrictions are required to be protective of human health and the 
environment. No planned future land uses nor operation and maintenance requirements have been identified for this site.

Previous sampling of contaminated soil at Site CPP-67 was performed, and sample results are detailed in the Group 3 RD/RA Work Plan (DOE-ID 2004a). Based on results of those investigations, remediation goals for Cs-137 and mercury were exceeded in samples from SWP-1; and the remediation goal for Cs-137 was exceeded in SWP-2. Because existing data were sufficient for soil waste characterization, a waste profile was completed. In accordance with the Characterization Plan (DOE-ID 2004d), verification sampling was performed as part of waste disposal. In reviewing previous sampling results, I-129 concentrations were identified as exceeding the ICDF landfill WAC concentration guidelines. As a result, taking verification samples was required to determine the I-129 curie loading for the ICDF landfill associated with soil to be remediated. The planned number of I-129 verification samples to be taken was based on results from the 1991 sampling that determined the mean activity for I-129 in SWP-1 and SWP-2 at 0.92 and $2.03 \mathrm{pCi} / \mathrm{g}$, respectively. However, when I-129 sampling was performed in SWP-1 prior to remediation in 2004, data identified higher levels of I-129 than expected. In reviewing this information and the fact that SWP-1 had continued to accept waste after the sampling in 1991, the Agencies agreed to collect a minimum of 66 additional I-129 samples from SWP-1. A total of 70 samples (i.e., 66 samples and 4 duplicates) were collected from SWP-1 and analyzed for I-129 prior to the remediation being performed. Based on sample results, the activity of I-129 from SWP-1 was conservatively calculated (using the 95\% UCL and one-half the method detection limit for all sampling having nondetectable concentrations) to be $0.03 \mathrm{Ci}$. This activity then was compared to the ICDF landfill limit of 2.4 Ci for I-129.

Iodine-129 verification sampling was performed in SWP-2 when contaminated soils were removed, as described in the ICDF I-129 Characterization Sampling Plan (PLN-1739). A total of 210 samples were taken, and results (validated in accordance with a Level B) indicated that of the 210 soil samples analyzed, the results were either qualified with a U (nondetect) or a UJ (false positive). Based on sample results that identified no measurable quantity of I-129, the activity of I-129 from SWP-2 was conservatively calculated (using the $95 \%$ UCL and one-half the method detection limit for all sampling having nondetectable concentrations) to be $0.01 \mathrm{Ci}$. This activity then was compared to the ICDF landfill limit of $2.4 \mathrm{Ci}$ for I-129.

Remedial design was based on additional data required to make decisions regarding RAs. Additional data requirements are listed below:

- Determine whether sites require remediation

- Ensure that adequate data are available for each site to complete a waste profile for disposal of waste

- Determine whether waste requiring remediation, for which I-129 is suspected, can be placed in the ICDF landfill.

To implement the RAO strategy, RD called for an excavation depth to be based on depth of the ponds where all detected soil COCs were below remediation goals (see Table 1-1). That depth was determined to be $61 \mathrm{~cm}(2.0 \mathrm{ft})$, based on Cs-137 and mercury being greater than remediation goals at 0 to $15.2 \mathrm{~cm}$ ( 0 to $0.5 \mathrm{ft})$ bgs (DOE-ID 2004a).

Remedial design called for the following actions:

- Prepare Title II design drawings containing

- Demolition of existing fencing and roadways and estimated quantities of debris

- $\quad$ Final configuration of fences, roadways, and ditches 
- $\quad$ Plot plans, contours, and quantities

- Sections and excavation profiles.

- Reroute existing utilities and surface features. Activities will be primarily limited to protecting the utilities while modifying surface features.

- Demolish Buildings CPP-1611 and CPP-1612, fencing, and several concrete slabs.

- $\quad$ Plug and abandon Well SWPP-23.

- Cut, cap, and remove portions of the service waste line and redundant service waste line.

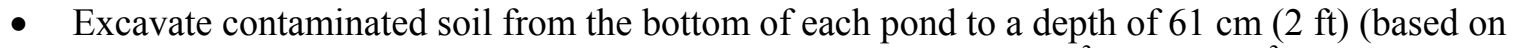
existing sampling data) for an estimated total volume of $22,849 \mathrm{~m}^{3}\left(29,885 \mathrm{yd}^{3}\right)$.

- Import approximately $22,172 \mathrm{~m}^{3}\left(29,000 \mathrm{yd}^{3}\right)$ of backfill material from stockpiles south of the existing ponds. The ponds were not to be backfilled, but the side slopes were to be shaped to a $4: 1$ run-to-rise slope. Place approximately $7,646 \mathrm{~m}^{3}\left(10,000 \mathrm{yd}^{3}\right)$ of topsoil over the pond surfaces and side slopes in a 15.2-cm (6-in.) lift.

- Revegetate ponds to complete remediation of this site.

\subsection{Remediation and Demolition Activities}

Remediation and demolition activities followed the scope of work provided to ICDF project management, based on OU 3-13 site areas excavation (following the general sequencing plan), as outlined in the RD/RA Work Plan (DOE-ID 2004a). The scope of work differed from the work plan, and these differences are described below. No construction interface documents were issued; thus, no change was made to work scope regarding the work plan and actual construction.

\subsubsection{Site Mobilization and Infrastructure Establishment}

Subcontractor mobilization began in July 2004. Work on improving the infrastructure was started first and included the following activities:

- Constructed a controlled-access haul road between CPP-67 and ICDF

- Installed a temporary scale to track quantities of soil removed from each pond

- Installed a dust-control system that uses water

- Modified fencing around the two ponds in preparation for demolition and excavation activities

- Confirmed location and orientation of diversion valves for primary and redundant service waste lines

- Finalized the utility isolation plan

- Installed soil ramps in each pond. 


\subsubsection{Demolition}

After establishing the remediation infrastructure, demolition began in accordance with the CPP-67 Demolition Plan (DOE-ID 2004a) and the COO-67 Piping Plan (DOE-ID 2004a), with completions described as follows:

- Buildings CPP-1611 and CPP-1612 rested on a 15.2-cm (6-in.) -thick concrete slab and contained piping of various diameters extending through each concrete slab, angled underground, and terminating near the base of each pond. The piping contained water-level detectors, and the buildings contained instrumentation and isolated $12-\mathrm{V}$ power sources to monitor water levels. Associated concrete slabs, piping, and instrumentation wiring were removed, demolished, and transported to ICDF.

- Staff gauges from each pond were removed and transported to ICDF.

- Concrete splash guards located at the primary and redundant discharge lines (two each per pond) were removed and transported to ICDF.

- Primary and redundant discharge piping — from just prior to the tees to the discharge points — was cut, removed, and transported to ICDF. The remaining piping (35.6- $\mathrm{cm}$ [14-in.] polyethylene) was capped in place (DOE-ID 2004a). The two manholes that contained the flow direction and control valves were removed and transported to ICDF.

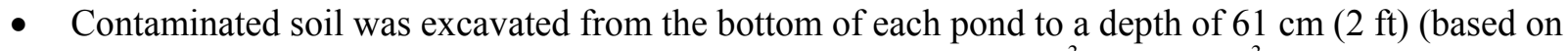
existing sampling data), for an estimated total volume of $22,849 \mathrm{~m}^{3}\left(29,885 \mathrm{yd}^{3}\right)$.

The demolition plan called for the metal chain-link fencing to be removed, the wire mesh to be salvaged, and the steel posts and concrete to be disposed of. This demolition was deferred to a later time (see Section 7.2.4 for more information). The demolition plan also called for removing monitoring Well SWPP-23; however, this was delayed due to unfavorable site conditions. Removal of Well SWPP-23 was rescheduled, and the task was completed on September 21, 2005.

\subsubsection{Excavation}

Excavation activities followed the CPP-67 Demolition Plan (Drawing 626004 in Appendix B of DOE-ID [2004a]). Pond 2 was excavated first. Work took place from August 9 through October 4, 2004,

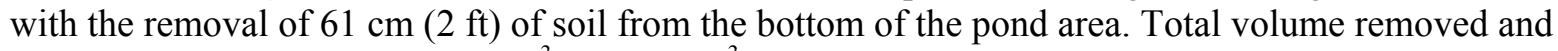
transported to ICDF was $16,076 \mathrm{~m}^{3}\left(21,026 \mathrm{yd}^{3}\right)$.

Excavation of Pond 1 took place from October 5 through November 2, 2004, with the removal of $61 \mathrm{~cm}(2 \mathrm{ft})$ of soil from most of the bottom of the pond. Basalt was hit in the southeast and southwest corners and along the west side of the pond at less than the 62-cm (2-ft) depth originally planned for excavation. Excavation stopped in these areas at top of the basalt. Total volume removed and transported to ICDF was $7,234 \mathrm{~m}^{3}\left(9,462 \mathrm{yd}^{3}\right)$.

\subsubsection{Area Completion}

Following verification that the CPP-67 site met OU 3-13 remediation goals, the finish plan for CPP-67 identified that approximately $29,818 \mathrm{~m}^{3}\left(39,000 \mathrm{yd}^{3}\right)$ of backfill material would be used to shape the side slopes to a 4:1 run-to-rise slope. This was to be followed with the import of approximately $7,646 \mathrm{~m}^{3}\left(10,000 \mathrm{yd}^{3}\right)$ of topsoil, to be placed over the remediated pond surfaces and side slopes, and 
seeding. During the site visit by Agency representatives on October 19, 2004, future use of the remediated ponds was discussed. The ponds were identified as being considered for use as a landfill for construction and demolition debris from building-demolition activities. Considering future reuse of this site, the side slope shaping, addition of topsoil, and seeding activities were not performed as part of the site's remediation. The remediated CPP-67 site will be used as a landfill for construction and demolition debris generated by general decommissioning activities at the INL Site. These decommissioning activities are being performed as a CERCLA non-time-critical removal action (DOE-ID 2006a). Operation and closure of this landfill would be performed under the auspices of the removal action and in accordance with applicable or relevant and appropriate requirements for a landfill. If the ponds are not used as a construction landfill, they will be graded and revegetated.

\subsection{Chronology of Events}

Table 7-1 presents a chronology of events for the CPP-67 project.

Table 7-1. Chronology of events for the CPP-67 project.

\begin{tabular}{|c|c|}
\hline Date & Event \\
\hline October 7, 1999 & Signed final ROD for INTEC (DOE-ID 1999). \\
\hline February 2004 & Finalized and transmitted RD/RA Work Plan (DOE-ID 2004a). \\
\hline April 2004 & Performed verification soil sampling at Ponds 1 and 2. \\
\hline July 2004 & $\begin{array}{l}\text { Began mobilization by establishing infrastructure improvements (e.g., built } \\
\text { controlled-access haul road from CPP- } 67 \text { to ICDF, installed temporary scales, } \\
\text { and installed dust-suppression system). }\end{array}$ \\
\hline August 9, 2004 & Completed CPP-67 mobilization and began excavation of Pond 2. \\
\hline August 19, 2004 & Completed development of waste profiles. \\
\hline August 19, 2004 & $\begin{array}{l}\text { Began verification soil sampling at Pond } 2 \text { during excavation, in accordance } \\
\text { with PLN-1739. }\end{array}$ \\
\hline September 2004 & Began reverification sampling activity at Pond 1 in accordance with PLN-1802 \\
\hline September 2, 2004 & $\begin{array}{l}\text { Reached agreement with the Agencies on sampling requirements for Pond } 1 \text { an } \\
\text { preparation of the associated waste profile. }\end{array}$ \\
\hline September 21, 2004 & $\begin{array}{l}\text { Completed verification soil sampling at Pond } 2 \text { during excavation, in } \\
\text { accordance with PLN-1739. }\end{array}$ \\
\hline September 27, 2004 & $\begin{array}{l}\text { Received acceptance of CPP- } 67 \text { Pond } 1 \text { waste stream for disposal in the ICDF } \\
\text { landfill. }\end{array}$ \\
\hline \multirow[t]{2}{*}{ September 30, 2004} & $\begin{array}{l}\text { Received approval to use water remaining in the service wastewater lines for } \\
\text { dust suppression during remediation of Pond } 1 .\end{array}$ \\
\hline & $\begin{array}{l}\text { Began preparations for remediation of Pond } 1 \text { by installing a truck ramp into th } \\
\text { pond. }\end{array}$ \\
\hline October 4, 2004 & $\begin{array}{l}\text { Completed excavation from Pond } 2 ; 16,076 \mathrm{~m}^{3}\left(21,026 \mathrm{yd}^{3}\right) \text { of soil was } \\
\text { removed and transferred to ICDF. }\end{array}$ \\
\hline October 5, 2004 & Began excavation work at Pond 1. \\
\hline October 7, 2004 & $\begin{array}{l}\text { Received letter from DEQ concerning laboratory analysis results for I-129. A } \\
\text { conference call was held on October 7, 2004, to address this issue. (Note: } \\
\text { Results from the conference call to be incorporated into the characterization } \\
\text { report.) }\end{array}$ \\
\hline
\end{tabular}


Table 7-1. (continued).

\begin{tabular}{|c|c|}
\hline Date & Event \\
\hline \multirow[t]{3}{*}{ October 8, 2004} & $\begin{array}{l}\text { Used water in the service wastewater lines for dust suppression during } \\
\text { remediation of Pond } 1 \text {. Completed Pond } 2 \text { excavation, and performed a gamma } \\
\text { survey. No Cs- } 137 \text { concentrations over } 23 \mathrm{pCi} / \mathrm{g} \text { were found. }\end{array}$ \\
\hline & Cut and capped service waste lines, in accordance with the design. \\
\hline & Began remediation of Pond 1 (i.e., excavation in progress). \\
\hline October 19, 2004 & $\begin{array}{l}\text { Conducted site tour of CPP- } 67 \text { for DOE, DEQ, EPA, and BBWI } \\
\text { representatives. }\end{array}$ \\
\hline October 27, 2004 & Disposed of all CPP-67 waste at ICDF. \\
\hline November 2004 & $\begin{array}{l}\text { Completed field gamma gross-radiation measurements at the east and west } \\
\text { percolation ponds by November } 2004 \text {, after completion of all excavation. }\end{array}$ \\
\hline November 2, 2004 & $\begin{array}{l}\text { Completed excavation work at Pond } 1 \text {; removed } 7,234 \mathrm{~m}^{3}\left(9,462 \mathrm{yd}^{3}\right) \text { from } \\
\text { Pond } 1 \text { and sent it to ICDF. }\end{array}$ \\
\hline November 5, 2004 & $\begin{array}{l}\text { Completed remediation of Pond 1. (Note: This meets performance-based } \\
\text { incentive goals for excavation of the old INTEC percolation ponds.) }\end{array}$ \\
\hline November 10, 2004 & $\begin{array}{l}\text { Transmitted the draft Characterization Report for Remediation Set } 1 \text { to the } \\
\text { Agencies. }\end{array}$ \\
\hline November 11, 2004 & $\begin{array}{l}\text { Completed sidewall survey (gamma scan) for Pond } 1 \text { with no significant cesium } \\
\text { detections. }\end{array}$ \\
\hline November 15, 2004 & $\begin{array}{l}\text { Performed confirmatory soil sampling at each pond, in accordance with the } \\
\text { CPP-67 Confirmatory Sampling Plan for INTEC Ponds } 1 \text { and } 2 \\
\text { (Kirchner 2005c). }\end{array}$ \\
\hline \multirow[t]{2}{*}{ November 19, 2004} & $\begin{array}{l}\text { Completed sidewall survey (gamma scan) for Pond } 2 \text { with no significant cesium } \\
\text { detections. }\end{array}$ \\
\hline & Completed subcontractor demobilization with decontamination of equipment. \\
\hline November 24, 2004 & $\begin{array}{l}\text { Transfer of facility back to Tenant and Support Operations from ICDF in } \\
\text { progress. }\end{array}$ \\
\hline \multirow[t]{2}{*}{ November 26, 2004} & Completed confirmatory sampling. \\
\hline & Completed subcontractor demobilization with decontamination of equipment. \\
\hline December 3, 2004 & Completed I-129 sample validation. \\
\hline January 14, 2005 & $\begin{array}{l}\text { Received additional I-129 analysis data from the BWXT laboratory. Began } \\
\text { work to update the characterization report. }\end{array}$ \\
\hline January 20, 2005 & Received limitations and validation report for additional I-129 analysis. \\
\hline January 27,2005 & $\begin{array}{l}\text { Transmitted limitations and validation report for additional I-129 analysis to the } \\
\text { Agencies. }\end{array}$ \\
\hline May 4, 2005 & Completed draft Characterization Report. \\
\hline July 20,2005 & Finalized Characterization Report (DOE-NE-ID 2005). \\
\hline
\end{tabular}




\subsection{Performance Standards and Construction Quality Control}

The OU 3-13 Phase I FSP was developed to guide sampling for the Group 3 sites (DOE-ID 2004b). The FSP was implemented with the latest revision of the QAPjP, which provides guidance for sampling, QA, QC, analytical procedures, and data management. Together, the QAPjP and the FSP constitute the RA SAP.

The RAO for the CPP-67 site, as stated in the RD/RA Work Plan for Group 3 soils, was to prevent exposure to contaminated surface soil, such that for all surface exposure pathways, a cumulative carcinogenic risk of $1 \times 10^{-4}$ and a total hazard index of 1 was not exceeded at each release site. To meet this RAO, remediation goals were established in the OU 3-13 ROD (DOE-ID 1999, p. 8-4) to ensure a risk-based protectiveness of human health and the environment. Performance results for RA confirmation sampling are compared to the remediation goals in Table 7-2, showing that the RAO was achieved.

Table 7-2. Comparison between risk-based remediation goals for OU 3-13, Other Soil Sites, and performance levels achieved for Site CPP-67.

\begin{tabular}{lcc}
\hline $\begin{array}{c}\text { Contaminant } \\
\text { of Concern }\end{array}$ & $\begin{array}{c}\text { Soil Risk-Based Remediation Goal } \\
\text { for Single Contaminants of Concern } \\
(\mathrm{pCi} / \mathrm{g})\end{array}$ & $\begin{array}{c}\text { Performance } \\
\text { Level Achieved }\end{array}$ \\
\hline $\begin{array}{l}\text { Radionuclides } \\
\text { Cs-137 }\end{array}$ & 23 & $3.13 \mathrm{pCi} / \mathrm{g}$ in Pond $\mathrm{a}^{\mathrm{a}}$ \\
Cs-137 & 23 & $6.15 \mathrm{pCi} / \mathrm{g} \mathrm{in} \mathrm{Pond} \mathrm{2}^{\mathrm{a}}$ \\
Eu-152 & 270 & Nondetect $^{\mathrm{b}}$ \\
Eu-154 & 5,200 & Nondetect $^{\mathrm{b}}$ \\
Inorganics & & $1.4 \mathrm{mg} / \mathrm{kg}^{\mathrm{b}}$ \\
$\quad$ Mercury (human health) & 23 & \\
\hline a. Value shown is the 95\% UCL resulting from the confirmation samples. \\
b. Performance level results are the highest analytical results received from both ponds.
\end{tabular}

\subsubsection{Sampling Activities and Results} Table 7-3.

The Environmental Services project performed soil sampling during four activities, as listed in

Table 7-3. Environmental Services project soil sampling activities for CPP-67.

\begin{tabular}{|c|c|c|c|}
\hline $\begin{array}{l}\text { Characterization } \\
\text { Sampling Number }\end{array}$ & Description & Sample Dates & $\begin{array}{l}\text { Analytes } \\
\text { Sampled For }\end{array}$ \\
\hline $\begin{array}{l}\text { ESP-034-04, } \\
\text { Rev. } 1\end{array}$ & $\begin{array}{l}\text { ICDF Verification Sampling-CPP-67 } \\
\text { Percolation Ponds (Ponds } 1 \text { and 2) }\end{array}$ & April 2004 & Metals \\
\hline ESP-062-04 & $\begin{array}{l}\text { ICDF I-129 Characterization } \\
\text { Sampling-CPP-67 Perc Ponds (Pond 2) }\end{array}$ & $\begin{array}{l}\text { August } 19 \text { through } \\
\text { September 21, } 2004\end{array}$ & $\mathrm{I}-129$ \\
\hline ESP-106-04 & $\begin{array}{l}\text { ICDF Characterization Sampling- } \\
\text { CPP-67 Percolation Pond } 1 \text {-Resample }\end{array}$ & September 23-28, 2004 & $\mathrm{I}-129$ \\
\hline ESP-116-04 & $\begin{array}{l}\text { CPP- } 67 \text { Confirmatory Sampling } \\
\text { (INTEC Ponds } 1 \text { and 2) }\end{array}$ & November 15, 2004 & $\begin{array}{l}\text { Gamma-emitting } \\
\text { radionuclide activity, } \\
\text { I- } 129, \text { mercury }\end{array}$ \\
\hline
\end{tabular}




\subsubsection{ESP-034-04 Sampling Activity}

Initial verification soil samples were collected from both ponds, in accordance with PLN-1662. In April 2004, soil samples were taken from the bottom of each pond, at depths ranging from 0.3 to $0.9 \mathrm{~m}$ ( 1 to $3 \mathrm{ft}$ ), using a grid pattern in the pond; samples were sent to an off-Site laboratory to be analyzed for metals. Verification sample results validated original characterization data for Pond 2. However, the sample results from Pond 1 exceeded acceptable validation levels for some contaminants; this led to resampling of Pond 1 under activity ESP-106-04.

\subsubsection{ESP-062-04 Sampling Activity}

Verification soil sampling was conducted at Pond 2 during excavation, in accordance with PLN-1739. Sampling was performed from August 19, 2004, through September 21, 2004. A total of 210 soil samples were collected intermittently from the top of the soil piled in the excavator so that approximately every $3,823 \mathrm{~m}^{3}\left(5,000 \mathrm{yd}^{3}\right)$ of soil removed was sampled. The samples were analyzed for I-129 at an off-Site laboratory (see Table C-1 in Appendix C). Data returned to the project were validated in accordance with a Level B validation.

\subsubsection{ESP-106-04 Sampling Activity}

Because results from soil samples taken from Pond 1 in April 2004 exceeded acceptable levels (i.e., exceeded the upper bounds of the waste profile), a reverification sampling activity was performed, in accordance with the PLN-1802. In September 2004, 66 samples were taken, with four duplicates from a grid pattern in the pond, and sent to an off-Site laboratory to be analyzed for I-129. The grid pattern used divided the pond bottom into 100 equally sized rectangles measuring approximately $13 \times 15 \mathrm{~m}$ $(41 \times 48 \mathrm{ft})$. Samples were collected from 0.61-m (2-ft) depths, except where sloughing prevented it; in which case, the depth at which refusal was met was noted in the field logbook. Data were validated in accordance with a Level B validation.

\subsubsection{ESP-116-04 Sampling Activity}

Confirmatory soil sampling was performed at each pond after completion of excavation activities, in accordance with the sampling plan detailed in Kirchner (2005c). Sampling was performed on November 15, 2004, and samples were collected for gamma-emitting radionuclide activity and I-129. In addition, soil samples for mercury were collected from Pond 1 . The samples were collected from eight randomly selected locations at each pond, following a $6.1-\times 6.1-\mathrm{m}(20-\times 20-\mathrm{ft})$ grid (DOE-ID 2004d). Data were validated in accordance with a Level B validation. Table C-3 in Appendix C provides radiological analyte data from Pond 1, Table C-4 presents radiological analyte data from Pond 2, and Table C-5 presents mercury data from Pond 1.

\subsubsection{Real-Time Instrumentation Results}

Gross-radiation measurements for gamma collected at the east and west percolation ponds were completed by November 2004, after completion of all excavation. Figure 7-1 contains an aerial photograph of the two ponds with plotted measurement locations. For the west-side pond, a Trimble Global Positioning System with survey-grade positioning was used to establish a grid shaped like an "X." Points around the high-water line of the four slopes supplemented this pattern. The same instrument was used for the east-side pond, but a systematic grid pattern on the bottom of the pond was established. Points around the high-water line of the four slopes also supplemented this pattern. 


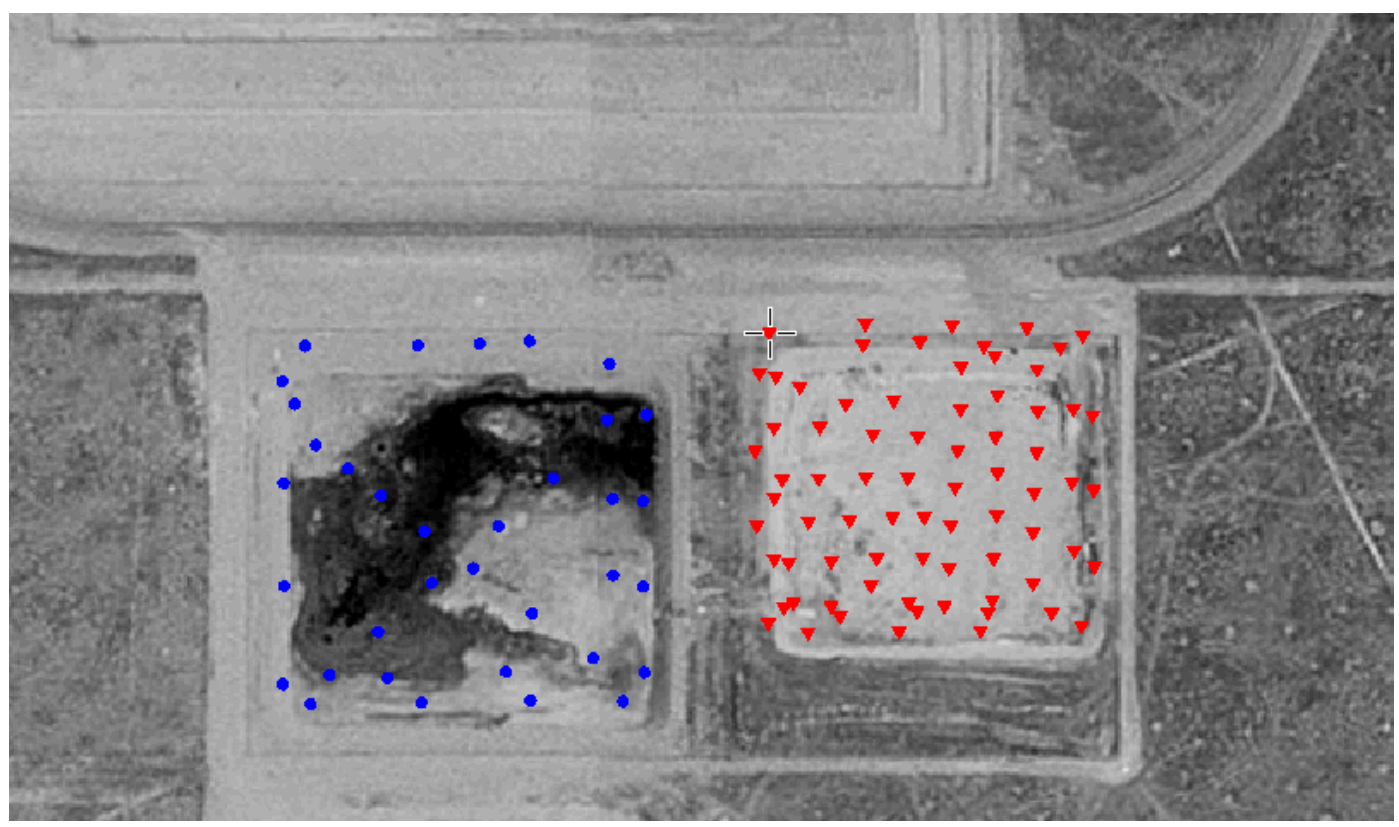

Figure 7-1. Aerial photograph of CPP-67, west and east percolation ponds. The figure shows the data measurement locations and grid pattern (north is up, no scale). Blue dots and red triangles represent locations where HPGe gamma scans were collected on the west and east ponds, respectively.

The system used for data collection consisted of a $42 \%$ efficient (relative to $3 \times 3$ sodium iodine) HPGe detector mounted on a tripod, with the detector face positioned $1 \mathrm{~m}(3.3 \mathrm{ft})$ above the ground. This arrangement yielded an optical field of view approximately $15.2 \mathrm{~m}(50 \mathrm{ft})$ in diameter at each measurement point. The detector was QC-checked daily, using a multinuclide point source traceable to the National Institute for Standards and Technology standard. Results from these checks were control-charted daily, and all values were within control limits for the duration of the project. Count times were for 20 to 30 minutes, ensuring precisions on the reported Cs- 137 concentration values that are less than $\pm 10 \%$ at the $2 \sigma$ confidence level. Spectral data also were analyzed. The ISO-Plus soil analysis program (AMT 2002) was used to calculate the final Cs-137 activities using the DOE M1 analysis protocol (DOE 1997) that has been used extensively at the INL Site and other DOE sites.

Results of the activity showed that all values for Cs- 137 were less than $23 \mathrm{pCi} / \mathrm{g}$, thus meeting the Cs-137 RA goal for these ponds. Figure 7-2 illustrates these results for the west percolation pond, and Figure 7-3 illustrates results for the east percolation pond. Appendix D provides the HPGe data.

\subsection{Final Inspection and Certification}

A site tour was conducted on October 19, 2004, for DOE, DEQ, EPA, and BBWI representatives. Excavation at Pond 2 was in progress during this tour. No deficiencies were identified; however, one observation was given by DEQ, stating that efforts should be given to collect side-slope data after excavation to confirm that contaminated soil is not left in place. In response to this observation, direction was given to collect HPGe data along the high-water line. Collection of these data was completed in November 2004, and the data results are contained in Appendix D. 


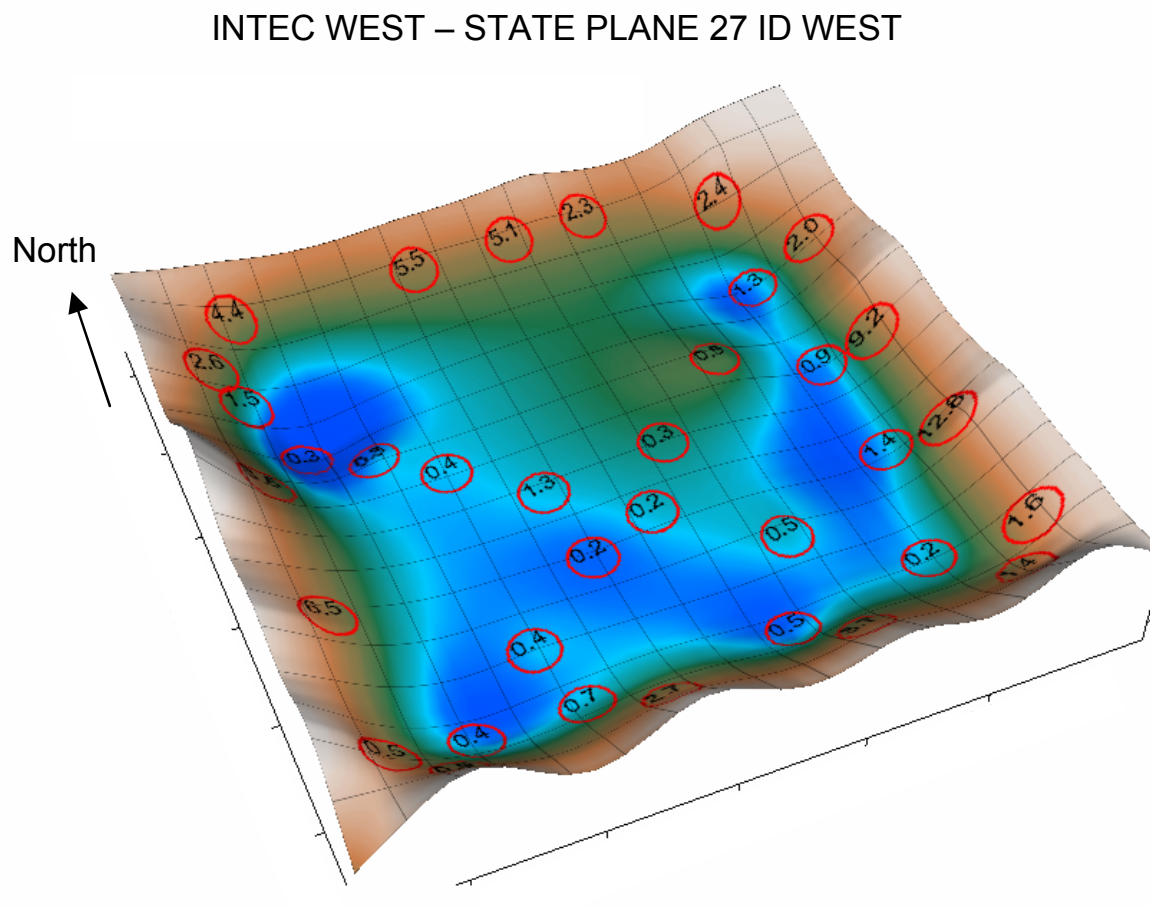

Figure 7-2. West percolation pond showing HPGe readings for Cs-137 in $\mathrm{pCi} / \mathrm{g}$ (no scale). Colors and shading are used only to enhance the contours and do not constitute radiological differences.

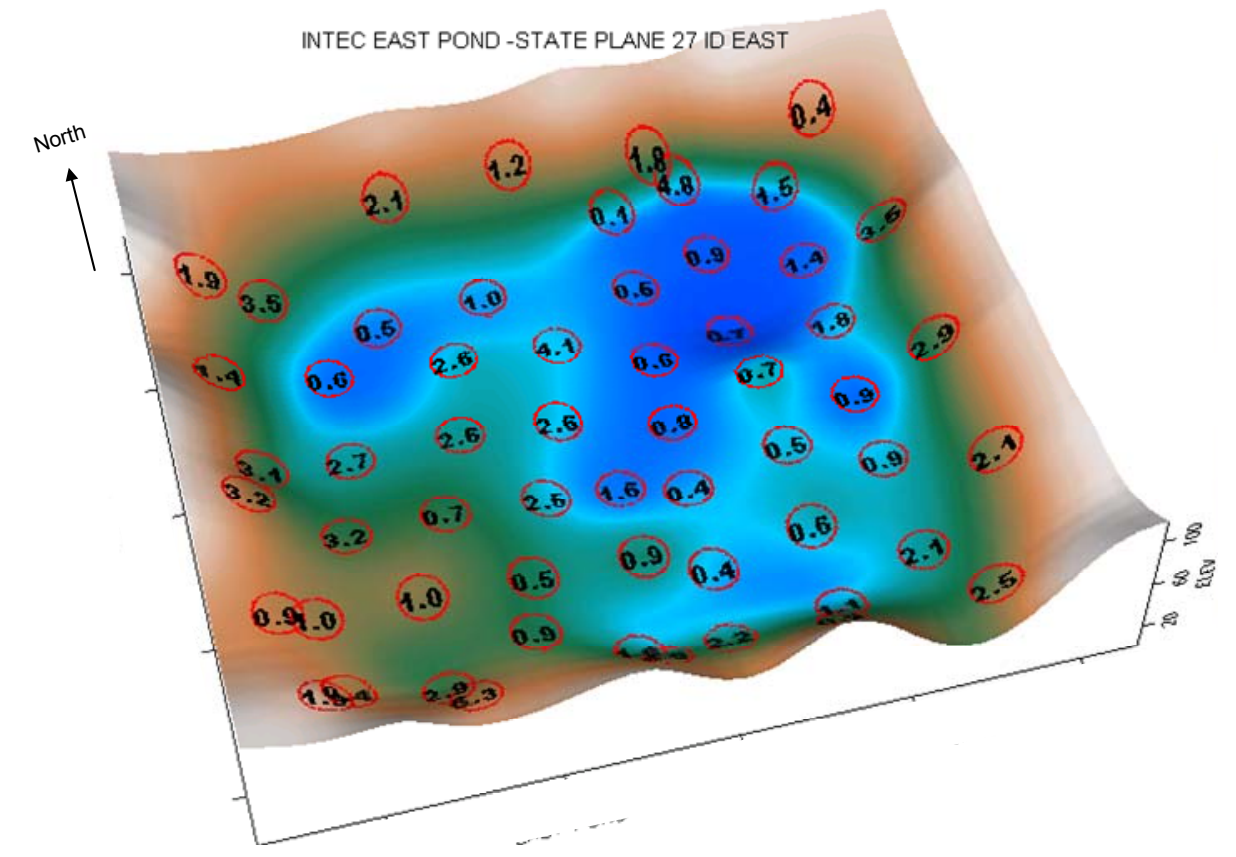

Figure 7-3. East percolation pond showing HPGe readings for Cs-137 in pCi/g (no scale). Colors and shading are used only to enhance the contours and do not constitute radiological differences. 
During this tour, discussions were held concerning the final configuration of the site. Modifications to the work plan scope included delaying the requirements to backfill and reshape the slopes, adding top soil, reseeding, and removing the fence. These modifications would allow the site to be left available for future use.

\subsection{Site Contact Information}

Table 7-4 provides contact information for the CPP-67 project.

Table 7-4. Contact information for the CPP-67 project.

\begin{tabular}{ll}
\hline \multicolumn{1}{c}{ Title } & \multicolumn{1}{c}{ Name } \\
\hline DOE-ID INL Site representative & Mary Verwolf \\
Primary contractor Subproject 6 project engineer & Marty Doornbos \\
Primary contractor Subproject 6 project manager & Lee Davison \\
Primary contractor subcontractor technical representative & Jody Landis \\
Primary contractor ICDF project manager & Jack Simonds \\
Primary contractor ICDF facility manager & Mike Edgett \\
Primary contractor radiological control technician foreman & Randy Spruill \\
Primary contractor subcontract administrator & Mike Drake \\
Stoller project management & Randy Haws \\
Stoller remediation lead & Brian Martenson \\
Envirocon facility manager & Dave Irvin \\
DEQ INL Site representative & Ted Livieratos \\
EPA INL Site representative & Dennis Faulk \\
\hline
\end{tabular}




$$
\text { 7-12 }
$$




\section{CPP-92, BOXED SOIL}

\subsection{Site Background}

Site CPP-92 was comprised of containerized waste located in the southwest portion of INTEC, west of CPP-1617, in the SSA (see Figure 1-2). This site consisted of 648 boxes containing soil (i.e., 567 boxes) and soil and debris (i.e., 81 boxes) that were generated from various INTEC plant projects, including

- $\quad$ Tank farm upgrade.

- Various CERCLA remediation projects.

- $\quad$ Building CPP-603 cleanup.

- $\quad$ Construction of the emergency fire exit tunnel for Building CPP-604/605 (Site CPP-89). Excavated soil was part of the tunnel excavation just south of and under CPP-604.

- Miscellaneous soil excavations at INTEC where soil contamination was encountered.

- Cleanup of soil and debris at Site CPP-17. Site CPP-17 was divided into two separate sites (i.e., CPP-17A and CPP-17B). These sites were used for storing piles of soil and debris that reportedly came from a variety of construction and maintenance activities within INTEC.

The OU 3-13 ROD identified that Site CPP-92 contained 648 boxes (DOE-ID 1999). However, by using the Integrated Waste Tracking System (IWTS) and physical inventories, Waste Generator Services identified 653 boxes. This discrepancy of five additional containers identified in the work plan (i.e., 85-001, 95-215, 93-516, 96-046, and 94-176) was determined in a query of the IWTS database for Site CPP-92 containers. However, these five containers were found not to be part of the OU 3-13 waste inventory because they were transferred to a low-level waste storage area (i.e., CPP-1790, a facility immediately north of CPP-1681 adjacent to CPP-1789) on October 5, 1999, prior to signing of the OU 3-13 ROD and subsequently disposed of at the Radioactive Waste Management Complex during February through April of 2000.

Characterization of CPP-92 and CPP-99 soil boxes was performed using a stratified approach, based on radiation measurements performed on the boxes and recorded in IWTS (DOE-ID 2004a; DOE-ID 2004c). Soil boxes were divided into three levels, based on radiation measurements. A total of 16 composite samples were analyzed for RCRA Appendix IX VOCs (40 CFR 264, Appendix IX), Appendix IX SVOCs, Universal Treatment Standard (UTS) metals, total metals, PCBs, and radiochemistry. In total, 59 samples were analyzed for I-129.

Sampling results are detailed in the Characterization Results Report (ICP 2005) and summarized here. The results were compared to Table UTS of 40 CFR 268.48 and to the ICDF landfill WAC, as applicable. All concentrations of applicable and positively detected VOCs, SVOCs, and PCBs are less than the standards, with over $95 \%$ of organic results either nondetect (i.e., U-flagged) or estimated nondetect (i.e., UJ-flagged). All positively detected toxicity characteristic leaching procedure (TCLP) inorganic concentrations are less than the standards, with $80 \%$ of TCLP results either nondetects or estimated nondetects. All positively identified radiochemical results were less than the standards. Analysis and reanalysis results provide evidence that I-129 is not present. 


\subsubsection{Summary of Remedial Design}

The remedial operation for Site CPP-92 consisted of transporting boxed waste from the SSA to ICDF. This was a routine waste-handling operation.

The general sequencing of operations performed for this RA are outlined below:

- $\quad$ Presort boxes before collecting additional characterization samples.

- Collect and analyze additional characterization samples in accordance with the Characterization Plan (DOE-ID 2004d).

- Develop waste profiles and determine ICDF WAC acceptability and applicability for stabilization to meet land disposal restrictions.

- $\quad$ Transfer soil and debris waste boxes to ICDF for direct disposal or to the Staging, Storage, Sizing, and Treatment Facility (SSSTF) within the ICDF Complex for treatment, as necessary. The specific sequencing of operations associated with transferring soil and debris waste boxes to ICDF from the SSA is outlined below:

- $\quad$ Establish a site boundary of sufficient size to allow staging and loading of a transport trailer and tractor unit at the SSA.

- $\quad$ Use a forklift with sufficient capacity to move boxes from the SSA and load them onto the tractor-trailer unit. Loading will be limited by weight-loading restriction on the tractor-trailer unit.

- $\quad$ Tie down the load, secure it to the trailer unit, and perform a final radiological survey for release.

- $\quad$ Drive the tractor-trailer unit from the SSA to ICDF, where it will be weighed and directed to the staging area to drop off the trailer and boxes.

\subsection{Remediation Activities}

Soil and debris waste boxes were transported to ICDF for disposal (Curnutt 2005a). Box numbers were confirmed as having been placed at ICDF. No spills or releases were associated with the transfer of the CPP-92 waste to ICDF for disposal, based on a review of spill team records. Butler (2006) documented these final actions on October 4, 2006.

\subsection{Chronology of Events}

On June 30, 2005, Site CPP-92 waste was accepted for disposition in the ICDF landfill, contingent upon successful completion of $\mathrm{pH}$ sampling and analysis of a representative sample of the waste stream.

Table 8-1 presents a chronology of events for the CPP-92 project. 
Table 8-1. Chronology of events for the CPP-92 project.

\begin{tabular}{ll}
\hline \multicolumn{1}{c}{ Date } & \multicolumn{1}{c}{ Event } \\
\hline October 7, 1999 & Signed final ROD for INTEC (DOE-ID 1999). \\
February 2004 & Finalized and transmitted RD/RA Work Plan (DOE-ID 2004a). \\
April-May 2004 & Completed characterization sampling. \\
August 19, 2004 & Completed development of Set 1 waste profiles. \\
October 19, 2004 & $\begin{array}{l}\text { Conducted site tour of CPP-92 for DOE, DEQ, EPA, and BBWI } \\
\text { representatives. }\end{array}$ \\
June 30, 2005 & $\begin{array}{l}\text { Received acceptance of waste from ICDF for “Area 92 CERCLA" } \\
\text { profile (Curnutt 2005a). }\end{array}$ \\
July 20, 2005 & Finalized characterization report (ICP 2005). \\
September 20, 2005 & Initiated CPP-92 waste shipments to ICDF. \\
November 16 and 17, 2005 & Conducted site tour of CPP-92 for DEQ, EPA, DOE, and BBWI. \\
December 6, 2005 & Finalized letter from DOE to EPA and DEQ concerning disposal of \\
equipment. & Transmitted prefinal inspection letter (Butler 2005). \\
December 8, 2005 & Completed CPP-92 waste shipments to ICDF. \\
March 2, 2006 & Sent closure report to EPA and DEQ (Butler 2006). \\
October 4, 2006 &
\end{tabular}

\subsection{Performance Standards and Construction Quality Control}

The OU 3-13 Phase I FSP was developed to guide sampling for the Group 3 sites (DOE-ID 2004b). The FSP was implemented with the latest revision of the QAPjP, which provides guidance for sampling, QA, QC, analytical procedures, and data management. Together, the QAPjP and the FSP constitute the RA SAP.

In accordance with the FSP, no confirmation sampling was necessary because Site CPP-92 did not require excavation.

\subsection{Final Inspection and Certification}

The prefinal inspection report identified two action items for CPP-92 (Butler 2005). The action items were to (1) submit waste tracking database information that documents transfer of all waste boxes from storage at the SSA to ICDF for disposal and (2) identify and status any spills or releases associated with transfer of waste boxes. Documentation of waste tracking and no spills or releases was transmitted in the final inspection report on October 4, 2006 (Butler 2006). 


\subsection{Site Contact Information}

Table 8-2 provides contacts for the CPP-92, CPP-98, and CPP-99 projects.

Table 8-2. Contact information for the CPP-92, CPP-98, and CPP-99 projects.

\begin{tabular}{ll}
\hline \multicolumn{1}{c}{ Title } & \multicolumn{1}{c}{ Name } \\
\hline DOE-ID WAG 3 project manager & Nicole Hernandez \\
Primary contractor Subproject 6 project manager & Lee Davison \\
Primary contractor subcontractor technical representative & Jody Landis \\
Primary contractor ICDF project manager & Jack Simonds \\
Primary contractor INTEC waste management facilities manager & Patrick Troescher \\
Primary contractor INTEC operations supervisor & Joel Hitz \\
DEQ INL Site representative & Ted Livieratos \\
EPA INL Site representative & Dennis Faulk/Diane Thangamani \\
\hline
\end{tabular}




\section{CPP-97, TANK FARM SOIL STOCKPILES FROM TANK FARM UPGRADE}

\subsection{Site Background}

Site CPP-97, located in the northeast portion of INTEC (see Figure 1-2), included two tarp-covered soil stockpiles and the contaminated surface soil surrounding those piles. The piles were generated from waste soil that originated from the Tank Farm Upgrade Project conducted during 1993, 1994, and 1995. One pile contained approximately $1,093 \mathrm{~m}^{3}\left(1,430 \mathrm{yd}^{3}\right)$ of radionuclide-contaminated soil. The second soil stockpile contained approximately $53 \mathrm{~m}^{3}\left(70 \mathrm{yd}^{3}\right)$ of radionuclide-contaminated soil. This upgrade project was divided into five areas within the INTEC tank farm. Areas 1, 2, and 3 are located on the north end of the tank farm. Area 4 is located on the west side, with Area 5 on the south side. Process knowledge indicated no known leaks of radioactive contamination from process lines and no environmentally controlled areas within Areas 1-4. Any potential contamination would have resulted from the tank farm; therefore, I-129 was not expected to be present at detectable concentrations. Soil from these areas went to the larger, lower-level contamination stockpile. Contamination in Area 5 was attributed to leaks from process lines identified as environmentally controlled areas and from releases associated with Waste Calcining Facility condensate. Soil from Area 5 could potentially contain I-129. Soil from this area was placed in the second, smaller stockpile.

Physical boundaries of Site CPP-97 were well defined. Radiological surveys defined the lateral extent of radiological contamination in the area surrounding the piles.

Characterization of Site CPP-97 followed the Characterization Plan (DOE-ID 2004d), with results reported in the Characterization Results Report (ICP 2005). Based on these results, concentrations of all COCs meet the ICDF landfill WAC for disposal (DOE-ID 2004c).

The selected remedy for Site CPP-97 comprised removal of contaminated soil and on-Site disposal into ICDF (DOE-ID 1999). No planned future land uses or operation and maintenance requirements have been identified for these sites.

\subsubsection{Summary of Remedial Design}

This section outlines activities designed for removing the soil piles and surface contaminated soil associated with Site CPP-97. Rerouting existing utilities was not required because no utilities were located at this site. The site boundary fence was the only surface feature to be removed.

Excavation of Site CPP-97 involved removal of the two soil stockpiles (including liners) and excavation of the contaminated surface soil within the boundary to a depth of $15.2 \mathrm{~cm}(6 \mathrm{in}$.). The estimated volume of soil from stockpiles was $1,127 \mathrm{~m}^{3}\left(1,474 \mathrm{yd}^{3}\right)$. The estimated volume of contaminated surface soil was $730 \mathrm{~m}^{3}\left(955 \mathrm{yd}^{3}\right)$.

The RD also called for (1) Title II drawings containing demolition and configuration of fencing and roadways, estimated quantities of debris, plot plans, contours, quantities, sections, and excavation profiles and (2) rerouting of existing roads and surface features.

The confirmation soil sampling strategy is described in detail in the OU 3-13 Phase I FSP (DOE-ID 2004b). Following remediation of the site, an initial radiological survey was performed for Cs-137 using a gamma spectrometer, followed by hot-spot removal, as necessary, and a resurvey and final confirmation sampling of the excavated surface to ensure compliance with RAOs. 
The site was backfilled with pit-run gravel. The estimated volume was $730 \mathrm{~m}^{3}\left(955 \mathrm{yd}^{3}\right)$. Contouring and grading to backfill the excavation were performed either to maintain existing surface water patterns or as designated in design drawings.

\subsection{Remediation and Demolition Activities}

Remediation and demolition activities followed the scope of work provided to ICDF project management. This scope was based on excavation of the OU 3-13 site areas (in accordance with the general sequencing plan) as outlined in the RD/RA Work Plan (DOE-ID 2004b).

\subsubsection{Site Mobilization and Infrastructure Establishment}

Subcontractor mobilization began in May 2005. Work on improving the infrastructure was started first and included the following activities:

- Constructed a controlled-access haul road between INTEC and ICDF

- Installed a dust-control system that used water

- Identified fencing around the northeast corner of INTEC as needing removal and protection prior to excavation activities.

\subsubsection{Excavation}

Excavation of Site CPP-97 took place from October 5, 2004, through November 17, 2004. Total volume removed and transported to ICDF was approximately $1,858 \mathrm{~m}^{3}\left(2,430 \mathrm{yd}^{3}\right)$.

An HPGe scan was performed in November 2005. Results of the activity showed that all values for Cs- 137 were less than $23 \mathrm{pCi} / \mathrm{g}$, meaning that the excavation was complete. Appendix E provides the HPGe data.

\subsubsection{Area Completion}

The finish plan called for importing approximately $730 \mathrm{~m}^{3}\left(955 \mathrm{yd}^{3}\right)$ of backfill material from stockpiles south of ICDF. The CPP-97 area was to be backfilled and contoured to the existing grade. No revegetation was required at this site.

\subsection{Chronology of Events}

Table 9-1 presents a chronology of events for the CPP-97 project.

Table 9-1. Chronology of events for the CPP-97 project.

Date

October 1999

February 2004

June 30, 2005

September 20-21, 2005
Event

Signed final ROD for INTEC (DOE-ID 1999).

Finalized and transmitted the RD/RA Work Plan (DOE-ID 2004a).

Received acceptance of waste profile "Area 92 CERCLA" from ICDF (Curnutt 2005a).

Began mobilization activities on CPP-97. 
Table 9-1. (continued).

Date

September 26, 2005

October 3, 2005

October 4, 2005

October 19, 2005

November 3, 2005

November 10, 2005

November 14, 2005

November 14, 2005

November 15, 2005

November 16-17, 2005

November 2005

November 28, 2005

December 8, 2005
Event

Completed dry run, and Radiological Engineering approved the process. Began building clean road into the stockpile.

Began mixing Tera Bond soil fixative with the CPP-97 stockpile.

Delivered first eight loads of CPP-97 stockpile to ICDF.

Completed stockpile removal and began removing the top $15.24 \mathrm{~cm}$ (6 in.) under the pile and from the surrounding area.

Began decontaminating heavy equipment and demobilizing the sprinkler system.

Completed excavating $15.24 \mathrm{~cm}$ (6 in.) below the stockpile and surrounding area.

Collected confirmation samples in accordance with the FSP.

Began backfilling the area.

Completed decontaminating heavy equipment.

Conducted site tour of CPP-97 for DEQ, EPA, DOE, and BBWI representatives.

Performed further field gamma gross-radiation measurements (as in accordance with comment from DEQ).

Completed backfill and demobilization of the area.

Transmitted prefinal inspection letter (Butler 2005).

\subsection{Performance Standards and Construction Quality Control}

The OU 3-13 Phase I FSP was developed to guide sampling for the Group 3 sites (DOE-ID 2004b). The FSP was implemented with the latest revision of the QAPjP, which provides guidance for sampling, QA, QC, analytical procedures, and data management. Together, the QAPjP and the FSP constitute the RA SAP.

The RAO for the CPP-97 site, as stated in the RD/RA Work Plan for Group 3 soils, was to prevent exposure to contaminated surface soils, such that for all surface exposure pathways, a cumulative carcinogenic risk of $1 \times 10^{-4}$ and a total hazard index of 1 was not exceeded. To meet this RAO, remediation goals were established in the OU 3-13 ROD (DOE-ID 1999, p. 8-4) to ensure risk-based protectiveness of human health and the environment. Performance results for RA confirmation sampling are compared to remediation goals in Table 9-2, showing that the RAO was achieved.

Table 9-2. Comparison between risk-based remediation goals for OU 3-13, Other Soil Sites, and performance levels achieved for Site CPP-97.

\begin{tabular}{ccc}
$\begin{array}{c}\text { Contaminant } \\
\text { of Concern }\end{array}$ & $\begin{array}{c}\text { Soil Risk-Based Remediation Goal } \\
\text { for Single Contaminants of Concern }\end{array}$ & $\begin{array}{c}\text { Performance } \\
\text { Level Achieved }^{\mathrm{a}}\end{array}$ \\
\hline Cs-137 & $3.14 \ln (\mathrm{pCi} / \mathrm{g})$ & $1.34 \ln (\mathrm{pCi} / \mathrm{g})$ \\
Sr-90 & $223(\mathrm{pCi} / \mathrm{g})$ & $5.14(\mathrm{pCi} / \mathrm{g})$ \\
\hline a. Value shown is the $95 \%$ UCL from the confirmation sampling results. & \\
\hline
\end{tabular}




\subsubsection{Sampling Activities and Results}

Confirmatory sampling was performed in accordance with the OU 3-13 Phase I FSP (DOE-ID 2004b).

9.4.1.1 ESP-073-05 Sampling Activity. Eight confirmation samples were collected from Site CPP-97 on November 14, 2005, (see Figure 9-1) and were analyzed in accordance with the FSP (DOE-ID 2004b). Results were reported in the Data Summary Report (ICP 2006b).

Confirmation samples collected at Site CPP-97, after remediation, showed the natural log-transformed average residual concentration for Cs-137 to be $0.61 \pm 0.74 \ln (\mathrm{pCi} / \mathrm{g})$. This value is substantially lower than the natural log-transformed remediation goal of $3.14 \ln (\mathrm{pCi} / \mathrm{g})$.

Confirmation samples collected at Site CPP-97, after remediation, showed the average residual concentration for total strontium to be $3.22 \pm 1.92 \mathrm{pCi} / \mathrm{g}$. This value is substantially lower than the remediation goal of $223 \mathrm{pCi} / \mathrm{g}$.

Results reported above indicate that remediation of Site CPP-97 is complete.

\subsection{Final Inspection and Certification}

The prefinal inspection report (Butler 2005) documents findings from the prefinal inspection checklist. Because no open items were found, this serves as the final inspection for Site CPP-97.

\subsection{Site Contact Information}

Table 9-3 provides contacts for the CPP-97 project.

Table 9-3. Contact information for the CPP-97 project.

\begin{tabular}{ll}
\hline \multicolumn{1}{c}{ Title } & \multicolumn{1}{c}{ Name } \\
\hline DOE-ID INL Site representative & Mary Verwolf \\
Primary contractor Environmental Restoration facility manager & Marty Doornbos \\
Primary contractor Environmental Restoration project manager & Lee Davison \\
Primary contractor subcontractor technical representative & Jody Landis \\
Primary contractor ICDF project manager & Jack Simonds \\
DEQ INL Site representative & Ted Livieratos \\
EPA INL Site representative & Dennis Faulk/Diane Thangamani \\
\hline
\end{tabular}




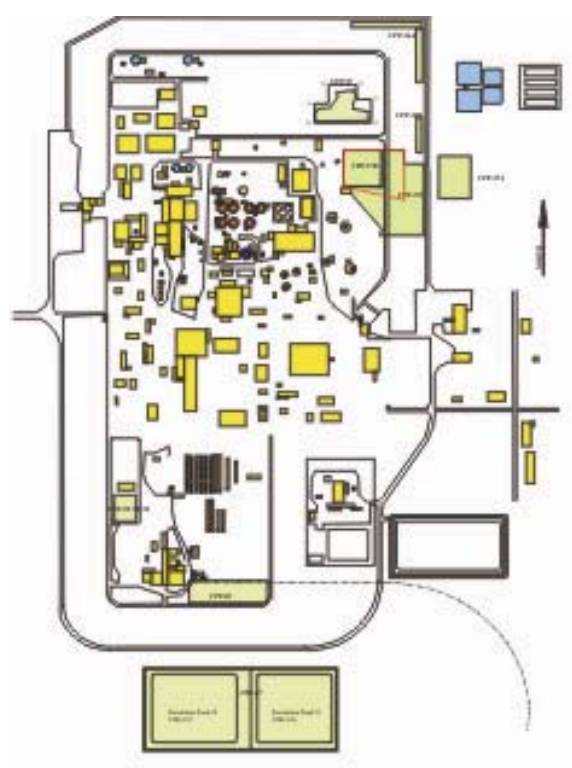

ì
Security Fence

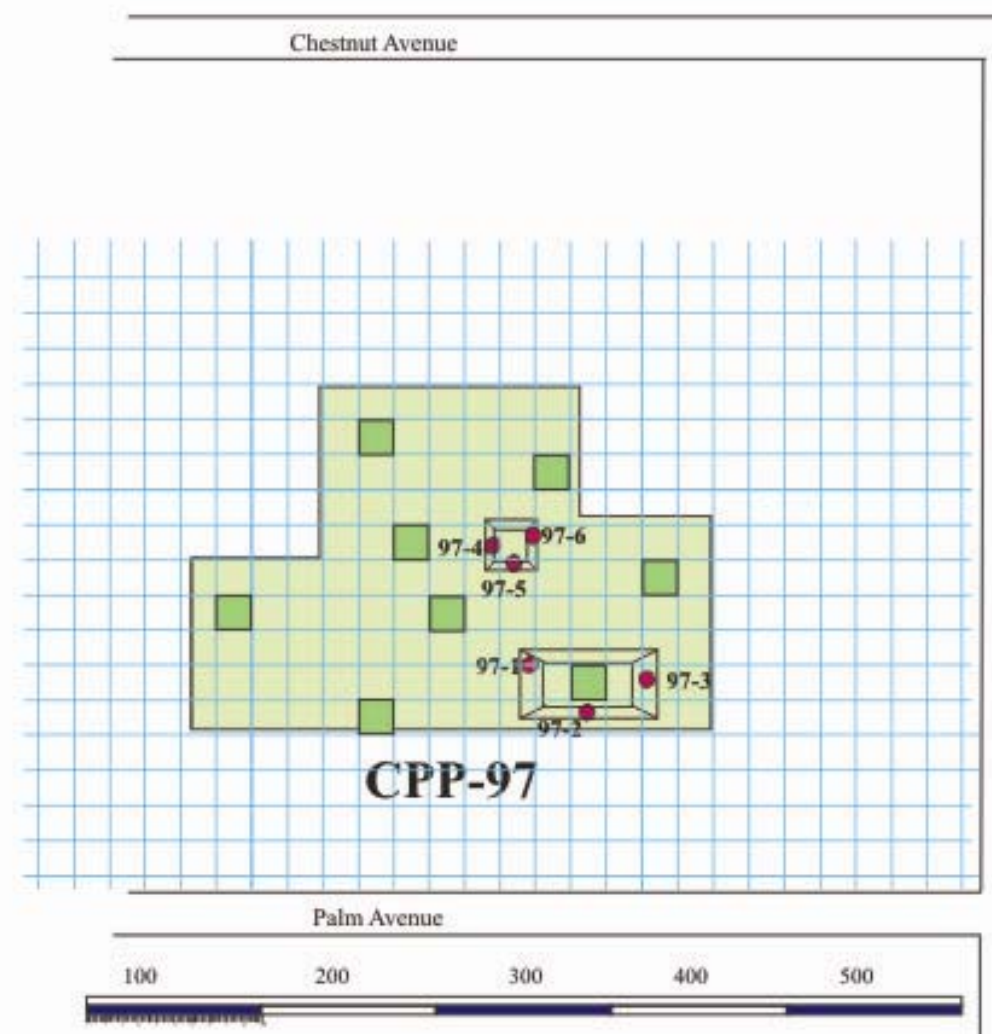

REFERENCE FOR COMPLIANCE SAMPLING STRATEGY

US EPA Methods for Evaluating the Attainment of Cleanup Standards

Voils and Solids Media, EPA 230/82-89-042, February 1989

From simple or Composite Random Sampling, Use Student's "T" Distribution

Coil site

G07-1920-02

Proposed Compliance Sampling:

CPP-97 Site

VS $97-1$ /VS $97-2$ /VS $97-3$ / VS $97-4$

V 97.5 / VS97-6/ $\mathrm{V} 597-7 /$ V $597-8$

Surface Grab Samples - Random Location

$20^{\prime} 0$ ' Grid Utilized

Random Sample Location

- Previous Characterization Sample Locations

Figure 9-1. Confirmation sampling locations for Site CPP-97. 
9-6 


\section{CPP-98, TANK FARM SHORING BOXES}

\subsection{Site Background}

Site CPP-98 comprised containerized waste consisting of 119 boxes of debris located in the southwest portion of INTEC, west of CPP-1617 (see Figure 1-2). These boxes contained wooden shoring used during the Tank Farm Upgrade Project. The OU 3-13 ROD identified that CPP-98 had 118 boxes (DOE-ID 1999). However, by using IWTS and a physical inventory, Waste Generator Services identified 119 boxes. Because the tank farm soil was contaminated, the shoring also became contaminated and was placed into $0.6-\times 1.2-\times 1.2-\mathrm{m}(2-\times 4-\times 8-\mathrm{ft})$ and $1.2-\times 1.2-\times 2.4-\mathrm{m}(4-\times 4-\times 8-\mathrm{ft})$ wooden waste boxes lined with a polyethylene membrane.

Sampling was not required for CPP-98 container debris because CPP-97 soil data were determined to be representative of the debris contamination.

\subsubsection{Summary of Remedial Design}

The remedial operation for Site CPP-98 consisted of transporting boxed waste from the SSA to ICDF. This was a routine waste-handling operation.

The general sequencing of operations for this RA is outlined below:

- $\quad$ Presort boxes before collecting additional characterization samples.

- Collect and analyze additional characterization samples in accordance with the Characterization Plan (DOE-ID 2004d).

- Develop waste profiles and determine ICDF WAC acceptability and applicability for stabilization to meet land disposal restrictions.

- $\quad$ Transfer soil and debris waste boxes to ICDF for direct disposal or to SSSTF within the ICDF Complex for treatment, as necessary. The specific sequencing of operations associated with transferring soil and debris waste boxes to ICDF from the SSA is outlined below:

- $\quad$ Establish a site boundary of sufficient size to allow staging and loading of a transport trailer and tractor unit at the SSA.

- $\quad$ Use a forklift with sufficient capacity to move boxes from the SSA and load them onto the tractor-trailer unit. Loading will be limited by weight-loading restriction on the tractor-trailer unit.

- $\quad$ Tie down the load, secure it to the trailer unit, and perform a final radiological survey for release.

- $\quad$ Drive the tractor-trailer unit from the SSA to ICDF, where it will be weighed and directed to the staging area to drop off the trailer and boxes.

\subsection{Remediation Activities}

A total of 119 wooden soil and debris waste boxes were transported to ICDF for disposal (Curnutt 2005b).

No spills or releases were associated with the transfer of Site CPP-98 CERCLA waste to ICDF for disposal, based on a review of spill team records (Butler 2006). 


\subsection{Chronology of Events}

Table 10-1 lists the order and dates of significant events associated with remediation of Site CPP-98.

Table 10-1. Chronology of events for the CPP-98 project.

\begin{tabular}{ll}
\hline \multicolumn{1}{c}{ Date } & \multicolumn{1}{c}{ Event } \\
\hline October 7, 1999 & Signed final ROD for INTEC (DOE-ID 1999). \\
February 2004 & Finalized and transmitted the RD/RA Work Plan (DOE-ID 2004a). \\
August 19, 2004 & Completed development of Set 1 waste profiles. \\
October 27, 2005 & Initiated shipment of CPP-98 and CPP-99 waste to ICDF. \\
November 16-17, 2005 & $\begin{array}{l}\text { Conducted site tour of CPP-98 for DOE, DEQ, EPA, and BBWI } \\
\text { representatives. }\end{array}$ \\
July 20, 2005 & Finalized characterization report (ICP 2005). \\
October 24, 2005 & $\begin{array}{l}\text { Accepted waste stream 2208N “INTEC Area 98/99: CERCLA Waste” for } \\
\text { disposition in the ICDF landfill (Curnutt 2005b). } \\
\text { December 8, 2005 }\end{array}$ \\
Transmitted prefinal inspection letter (Butler 2005). \\
Completed disposal shipments to ICDF. \\
October 4, 2006
\end{tabular}

\subsection{Performance Standards and Construction Quality Control}

The OU 3-13 Phase I FSP was developed to guide sampling for Group 3 sites (DOE-ID 2004b). The FSP was implemented with the latest revision of the QAPjP, which provides guidance for sampling, QA, QC, analytical procedures, and data management. Together, the QAPjP and the FSP constitute the RA SAP.

In accordance with the FSP, no confirmation sampling was necessary for Site CPP-92 because it did not require excavation.

\subsection{Final Inspection and Certification}

The prefinal inspection report (Butler 2005) identified two action items for Site CPP-98: (1) submit waste tracking database information to document transfer of all waste boxes from storage at the SSA to ICDF for disposal and (2) identify and status any spills or releases associated with transfer of the waste boxes. Documentation of waste tracking and no spills or releases was transmitted in the final inspection report on October 4, 2006 (Butler 2006).

\subsection{Site Contact Information}

Table 8-2 provides contact information for the CPP-98 project. 


\section{CPP-99, BOXED SOIL}

\subsection{Site Background}

Site CPP-99 comprised a group of boxes located in the southwest portion of INTEC, west of CPP-1617, in the SSA (see Figure 1-2). This site consisted of 58 boxes containing radionuclidecontaminated soil (i.e., 14 boxes), soil and debris (i.e., 43 boxes), and unknown contents (i.e., 1 box) generated from the Tank Farm Upgrade and CPP-604/605 Emergency Fire Tunnel Excavation projects. The OU 3-13 ROD (DOE-ID 1999) identified that CPP-99 had 59 boxes; however, using IWTS and a physical inventory, Waste Generator Services identified only 58 boxes. The boxes were wooden waste boxes lined with a polyethylene membrane.

Soil data from Sites CPP-97 and CPP-92 were assumed to be representative of Site CPP-99. Additionally, data also were available for excavated soil from the excavation for the fire exit from Building CPP-604/605 (Site CPP-92) and were assumed to be representative of Site CPP-99, as well.

Characterization of CPP-92 and CPP-99 soil boxes was performed using a stratified approach based on radiation measurements performed on the boxes and recorded in IWTS (DOE-ID 2004a; DOE-ID 2004c). The soil boxes were divided into three levels, based on radiation measurements. A total of 16 composite samples were analyzed for RCRA Appendix IX VOCs (40 CFR 264, Appendix IX), Appendix IX SVOCs, UTS metals, total metals, PCBs, and radiochemistry. A total of 59 samples were analyzed for I-129.

Results of the sampling are detailed in the Characterization Results Report (ICP 2005). The results were compared to Table UTS of 40 CFR 268.48 and to the ICDF landfill WAC, as applicable. All applicable and positively detected concentrations of VOCs, SVOCs, and PCBs were less than the standards, with over $95 \%$ of organic results either nondetect (i.e., U-flagged) or estimated nondetect (i.e., UJ-flagged). All positively detected TCLP inorganic concentrations were less than the standards, with $80 \%$ of TCLP concentrations either nondetect or estimated nondetect. All positively identified radiochemical concentrations were less than the standards. Analysis and reanalysis results provide evidence that I-129 was not present.

\subsubsection{Summary of Remedial Design}

The remedial operation for Site CPP-99 consisted of transporting boxed waste from SSA to ICDF. This was a routine waste-handling operation.

The general sequencing of operations performed for this RA is outlined below:

- $\quad$ Presort boxes before collecting additional characterization samples.

- Collect and analyze additional characterization samples in accordance with the Characterization Plan (DOE-ID 2004d).

- $\quad$ Develop waste profiles and determine ICDF WAC acceptability and applicability for stabilization to meet land disposal restrictions. 
- Transfer soil and debris waste boxes to ICDF for direct disposal or to SSSTF within the ICDF Complex for treatment, as necessary. The specific sequencing of operations associated with transferring soil and debris waste boxes to ICDF from SSA is outlined below:

- $\quad$ Establish a site boundary of sufficient size to allow staging and loading of a transport trailer and tractor unit at SSA.

- $\quad$ Use a forklift with sufficient capacity to move boxes from SSA and load them onto the tractor-trailer unit. Loading will be limited by weight-loading restriction on the tractor-trailer unit.

- $\quad$ Tie down the load, secure it to the trailer unit, and perform a final radiological survey for release.

- $\quad$ Drive the tractor-trailer unit from SSA to ICDF, where it will be weighed and directed to the staging area to drop off the trailer and boxes.

\subsection{Remediation Activities}

A total of 58 wooden soil and debris waste boxes were transported from Site CPP-99 to ICDF for disposal (Curnutt 2005b). No spills or releases were associated with the transfer of CPP-99 waste to ICDF for disposal, based on a review of spill team records (Butler 2006).

\subsection{Chronology of Events}

Table 11-1 lists the order and dates of significant events associated with remediation of Site CPP-99.

Table 11-1. Chronology of events for the CPP-99 project.

\begin{tabular}{ll}
\hline \multicolumn{1}{c}{ Date } & \multicolumn{1}{c}{ Event } \\
\hline October 7, 1999 & Signed final ROD for INTEC (DOE-ID 1999). \\
February 2004 & Finalized and transmitted the RD/RA Work Plan (DOE-ID 2004a). \\
August 19, 2004 & Completed development of Set 1 waste profiles. \\
July 20, 2005 & Finalized characterization report (ICP 2005). \\
October 24, 2005 & Waste stream 2208N "INTEC Area 98/99: CERCLA Waste" accepted for \\
& disposition in the ICDF landfill (Curnutt 2005b). \\
October 27, 2005 & $\begin{array}{l}\text { Initiated shipment of CPP-98 and CPP-99 waste to ICDF. } \\
\text { Conducted site tour of CPP-99 for DOE, DEQ, EPA, and BBWI }\end{array}$ \\
November 16-17, 2005 & $\begin{array}{l}\text { representatives. } \\
\text { Transmitted prefinal inspection letter (Butler 2005). } \\
\text { January 10, 2006 }\end{array}$ \\
October 4, 2006 & $\begin{array}{l}\text { Completed shipment of CPP-98 and CPP-99 waste to ICDF. } \\
\text { Sent closure report to EPA and DEQ (Butler 2006). }\end{array}$ \\
\hline
\end{tabular}




\subsection{Performance Standards and Construction Quality Control}

The OU 3-13 Phase I FSP was developed to guide sampling for Group 3 sites (DOE-ID 2004b). The FSP was implemented with the latest revision of the QAPjP, which provides guidance for sampling, QA, QC, analytical procedures, and data management. Together, the QAPjP and the FSP constitute the RA SAP.

In accordance with the FSP, no confirmation sampling was necessary for Site CPP-92 because it did not require excavation.

\subsection{Final Inspection and Certification}

The prefinal inspection report (Butler 2005) identified two action items for Site CPP-99: (1) submit waste tracking database information documenting transfer of all waste boxes from storage at SSA to ICDF for disposal and (2) identify and status any spills or releases associated with transfer of the waste boxes. Documentation of waste tracking and no spills or releases was transmitted in the final inspection report on October 4, 2006 (Butler 2006).

\subsection{Site Contact Information}

Table 8-2 provides contacts for the CPP-99 project. 
11-4 


\section{PHASE I ADDITIONAL WORK SCOPE}

DOE-ID requested and received Agency concurrence on the disposal of 10 pieces of contaminated construction equipment as part of the RA associated with Sites CPP-92, CPP-97, CPP-98, and CPP-99 (Hernandez 2005).

In January 2007, equipment was prepared for disposal by draining all fluids and subsequently was transported and disposed of in ICDF. All associated waste was transported to approved CERCLA waste treatment and disposal facilities. 


$$
\text { 12-2 }
$$




\section{OPERATIONS AND SITE MAINTENANCE}

None of the sites require operation and maintenance activities. The Long-Term Land Use Future Scenarios for the Idaho National Engineering Laboratory (DOE-ID 1995) describes Group 3, Phase I site characteristics and development constraints by which these sites will be managed. The INL Sitewide Institutional Controls Plan (DOE-ID 2006b) assumes that Phase I sites will remain under government management and control as planned industrial use until the year 2095.

The Group 3 sites have been remediated to below the OU 3-13 remediation goals. Unrestricted use, or use of the sites under a residential scenario, requires the average Cs-137 activity to be at or below $2.3 \mathrm{pCi} / \mathrm{g}$. Institutional controls will be implemented until such time as the average Cs-137 activity has decreased to at least $2.3 \mathrm{pCi} / \mathrm{g}$, as shown here, or until a 5-year review determines institutional controls are no longer needed. Table 13-1 lists the average remaining Cs-137 activity for each site, based on confirmation sampling, upon which was calculated the period required for institutional controls.

The fraction of activity due to Cs-137 remaining after a given time is calculated from the following equation:

$\frac{\mathrm{A}}{\mathrm{A}_{0}}=2^{-\mathrm{t} / \mathrm{T}}=\mathrm{e}^{-.693 \mathrm{t} / \mathrm{T}}$

where:
$\mathrm{A}$ is the remaining activity
$\mathrm{A}_{0}$ is the initial activity
$\mathrm{t} \quad=\quad$ time of decay
$\mathrm{T}=$ the Cs-137 half-life of 30.23 years.

Rearranging the equation to solve for $t$ when $A_{0}$ will equal the activity shown in Column 2 of Table 13-1, and A equals $2.3 \mathrm{pCi} / \mathrm{g}$, yields the institutional control period $(\mathrm{t})$ shown in Column 5. 
Table 13-1. Expected institutional control period for the sites reported in this Remedial Action Report.

\begin{tabular}{|c|c|c|c|c|c|c|}
\hline $\begin{array}{l}\text { OU 3-13 } \\
\text { Soil Site } \\
\end{array}$ & $\begin{array}{l}\text { 95\% UCL Residual } \\
\text { Cs-137 Activity } \\
\text { After Remediation } \\
(\mathrm{pCi} / \mathrm{g})\end{array}$ & $\begin{array}{l}\text { 95\% UCL Residual Total } \\
\text { Strontium Activity } \\
\text { After Remediation } \\
\text { (pCi/g) }\end{array}$ & $\begin{array}{l}\text { Reference for } \\
\text { the Values in } \\
\text { Column } 2\end{array}$ & $\begin{array}{l}\text { Period of } \\
\text { Institutional } \\
\text { Control }^{\mathrm{a}} \\
(\mathrm{yr})\end{array}$ & $\begin{array}{c}\text { Date of } \\
\text { Confirmation } \\
\text { Sampling } \\
\end{array}$ & $\begin{array}{c}\text { Expected Date for } \\
\text { Terminating } \\
\text { Institutional Controls }\end{array}$ \\
\hline CPP-34A & $1.5^{\mathrm{c}}$ & 1.5 & Kirchner (2005b) & NA & NA & NA \\
\hline CPP-34B & $1.5^{\mathrm{c}}$ & 1.5 & Kirchner (2005b) & NA & NA & NA \\
\hline CPP-37A & 3.6 & NA & $\begin{array}{l}\text { DOE-ID (2004a) } \\
\text { (Appendix A) }\end{array}$ & 20 & 1991 & 2011 \\
\hline CPP-37C & $2.17^{\mathrm{e}}$ & NA & ICP (2006a) & NA & NA & NA \\
\hline CPP-67, Pond 1 & 3.13 & NA & Table C-6 & 14 & November 2004 & 2019 \\
\hline CPP-67, Pond 2 & 6.15 & NA & Table C-7 & 43 & November 2004 & 2049 \\
\hline CPP-92 & NA & NA & NA & NA & NA & NA \\
\hline CPP-97 & $3.82^{\mathrm{f}}$ & 5.14 & $\operatorname{ICP}(2006 \mathrm{~b})$ & 23 & November 2005 & 2029 \\
\hline
\end{tabular}




\section{LESSONS LEARNED}

\subsection{Soils Sampling Techniques}

Performing Phase I remediations provided many opportunities to investigate and aid the process of verifying the attainment of remediation goals during and after removing radioactively contaminated soils. Confirmatory sampling techniques defined by the RD/RA Work Plan required collecting physical samples and performing laboratory analysis to validate the assertion that remediation goals were met. Traditional methods of sampling required significant planning, preparation, personnel risk (associated with collection), time to perform laboratory analysis, data reporting, and associated expenses.

Three methods of field-deployed real-time dosimetry sampling were used to aid and facilitate excavation activities, including (1) portable HPGe detector, (2) portable sodium iodide detection system, and (3) portable lanthanum bromide detection system. These systems provided detection of gamma radiation sources (e.g., Cs-137) and allowed timely field assessments of soil contamination levels such that excavation crew and equipment standby time was minimized.

Using these field real-time systems was very effective, as indicated by physical confirmatory sampling results, and it substantiated the elimination of traditional physical confirmatory sampling in lieu of the field-deployed real-time methods for all Phase II radioactively contaminated sites.

\subsection{Equipment and Contamination Control Techniques}

The INL Site is located in a high desert with prevailing southwest winds in the afternoon. These climate conditions can be a challenge when dealing with the types of soil encountered during excavation. Approximately $76,456 \mathrm{~m}^{3}\left(100,000 \mathrm{yd}^{3}\right)$ of soil were remediated during Phase I activities without any releases to the environment during the process. Several different excavation methods were employed, ranging from hand excavation and the use of small containers to large construction excavators and 30-ton articulated haul trucks.

Contamination controls included the use of water and water with binding agents to control fugitive dust emissions and engineered liners made of thin plastic sheeting for roll-on/roll-off containers and welded steel plate for articulated truck beds. These various controls performed well for the conditions experienced during the Phase I tasks. Highest efficiencies were associated with the larger equipment used on CPP-67, CPP-34A/34B, and CPP-03. The added effort and cost of dust suppression to prepare soil for excavation with the larger equipment are worthwhile if larger volumes and working conditions allow for their economic use.

The roll-on/roll-off container systems required more open space for maneuvering because of the long wheelbase on the hook-trucks, their hauling capacities were limited compared to the larger articulated dump trucks, and the preparation for loading and hauling required more manpower to execute.

Using small wheel loaders or wheeled loader-hoes and smaller metal boxes (BR-91) was least cost-effective but necessary in locations where tight quarters or very small quantities were involved. 


\subsection{Preremediation Subsurface Investigation Techniques}

Phase I excavations covered large areas inside and outside of the INTEC security enclosure and near some abandoned and operational subsurface utilities. Unexpected objects were encountered during some of the site excavations and required the use of additional subsurface investigative techniques to map anomalies within the excavation zones. Techniques included standard radiofrequency sensing devices typically used by the subsurface investigation team at INTEC, standard metal detection equipment (e.g., commercial metal detectors and magnetic locators), and state-of-the-art TDEMI instruments and magnetometers).

During Phase I actions, it became apparent that typical subsurface investigations were not adequate. Consequently, future Phase II excavations will be investigated using some, if not all, the techniques mentioned above to aid in planning work at complex and congested areas of the plant and to reduce risks during excavation. 


\section{SUMMARY OF PROJECT COSTS}

The RD/RA Work Plan Phase I cost estimate for remedy implementation included all RD/RA for OU 3-13, Group 3, Other Surface Soils, Phase I sites. The work plan estimate was $\$ 11,118,562$.

Work began in FY 2003 and was completed in FY 2007. Total cost associated with the performance of the defined work scope as noted in this report was $\$ 10,124,000$. The overall deviation from the original estimate provided above was approximately $9 \%$ (underrun). 


$$
\text { 15-2 }
$$




\section{REFERENCES}

40 CFR 264, Appendix IX, 2006, "Ground-Water Monitoring List," Code of Federal Regulations, Office of the Federal Register, July 2006.

40 CFR 268.48, 2006, "Universal Treatment Standards," Code of Federal Regulations, Office of the Federal Register, July 2006.

40 CFR 300, 2007, "National Oil and Hazardous Substances Pollution Contingency Plan," Code of Federal Regulations, Office of the Federal Register, July 2007.

54 FR 48184, 1989, "National Priorities List for Uncontrolled Hazardous Waste Sites," FRL 3681-4, Federal Register, U.S. Environmental Protection Agency, November 21, 1989.

42 USC $\S 6901$ et seq., 1976, "Resource Conservation and Recovery Act of 1976 (Solid Waste Disposal Act)," United States Code, October 21, 1976.

42 USC $\S 9601$ et seq., 1980, "Comprehensive Environmental Response, Compensation and Liability Act of 1980 (CERCLA/Superfund)," United States Code, December 11, 1980.

AMT, 2002, ISO-Plus-B32 Software User's Manual, Version 3, Oak Ridge, Tennessee: Advanced Measurement Technologies, 2002.

Butler, Lane, CH2M-WG Idaho, to Provencher, Richard, DOE-ID, December 7, 2005, "Contract No. DE-AC07-05ID14516 - Prefinal Inspection Report for CPP-34A/B, CPP-97, CPP-92, CPP-98, and CPP-99," JLB-115-05, CCN 301636.

Butler, Lane, CH2M-WG Idaho, to N. Ceto, EPA, and D. Koch, DEQ, October 4, 2006, "Transmittal of the INTEC Operable Unit 3-13, Group 3, Sites CPP-92, CPP-98, and CPP-99 Pre-Final/Final Inspection Closure Report," JLB-123-06, CCN 303541.

Butler, Lane, CH2-WG Idaho, to N. Ceto, EPA, and D. Koch, DEQ, February 15, 2007, "Transmittal of the INTEC Operable Unit 3-13, Group 3, Site CPP-03 Pre-Final/Final Inspection Report," JLB 21-07, CCN 304371.

Curnutt, Jim, Stoller, to Lee Davison, CH2M-WG Idaho, June 30, 2005a, (no subject), 420-010-047.

Curnutt, Jim, Stoller, to Lee Davison, CH2M-WG Idaho, October 24, 2005b, (no subject), 420-010-058.

DOE, 1997, Procedures Manual, HASL-300, 28th edition, Environmental Measurements Laboratory, U.S. Department of Energy, February 1997.

DOE-ID, 1991, Federal Facility Agreement and Consent Order for the Idaho National Engineering Laboratory, Administrative Docket No. 1088-06-29-120, U.S. Department of Energy Idaho Operations Office, U.S. Environmental Protection Agency Region 10, Idaho Department of Health and Welfare, December 4, 1991.

DOE-ID, 1995, Long-Term Land Use Future Scenarios for the Idaho National Engineering Laboratory, DOE/ID-10440, U.S. Department of Energy Idaho Operations Office, August 1995. 
DOE-ID, 1997, Comprehensive RI/FS for the Idaho Chemical Processing Plant OU 3-13 at the INEEL-Part B, FS Report (Final), DOE/ID-10572, U.S. Department of Energy Idaho Operations Office, November 1997.

DOE-ID, 1999, Final Record of Decision, Idaho Nuclear Technology and Engineering Center, Operable Unit 3-13, Idaho National Engineering and Environmental Laboratory, Idaho Falls, Idaho, DOE/ID-10660, Rev. 0, U.S. Environmental Protection Agency, Idaho Department of Environmental Quality, U.S. Department of Energy Idaho Operations Office, October 1999.

DOE-ID, 2002, Operable Unit 3-13, Group 3, Other Surface Soils, Prioritization and Site Grouping Report, DOE/ID-10996, Rev. 0, U.S. Department of Energy Idaho Operations Office, September 2002.

DOE-ID, 2004a, Operable Unit 3-13, Group 3, Other Surface Soils Remediation Sets 1-3 (Phase I) Remedial Design/Remedial Action Work Plan, DOE/ID-11089, Rev. 0, U.S. Department of Energy Idaho Operations Office, February 2004.

DOE-ID, 2004b, Operable Unit 3-13, Group 3, Other Surface Soils Remediation Sets 1-3 (Phase I) Field Sampling Plan, DOE/ID-11091, Rev. 0, U.S. Department of Energy Idaho Operations Office, February 2004.

DOE-ID, 2004c, Quality Assurance Project Plan for Waste Area Groups 1, 2, 3, 4, 5, 6, 7, 10, and Deactivation, Decontamination, and Decommissioning, DOE/ID-10587, Rev. 8, U.S. Department of Energy Idaho Operations Office, March 2004.

DOE-ID, 2004d, Operable Unit 3-13, Group 3, Other Surface Soils Remediation Sets 1-3 (Phase I) Characterization Plan, DOE/ID-11090, Rev. 0, U.S. Department of Energy Idaho Operations Office, February 2004.

DOE-ID, 2005a, Operable Unit 3-13, Group 3, Site CPP-03 Field Sampling Plan, DOE/ID-11246, Rev. 0, U.S. Department of Energy Idaho Operations Office, October 2005.

DOE-ID, 2005b, ICDF Complex Waste Acceptance Criteria, DOE/ID-10881, Rev. 2, U.S. Department of Energy Idaho Operations Office, October 2006.

DOE-ID, 2006a, Action Memorandum for General Decommissioning Activities under the Idaho Cleanup Project, DOE/ID-11293, Rev. 0, U.S. Department of Energy Idaho Operations Office, October 2006.

DOE-ID, 2006b, INL Sitewide Institutional Controls Plan, DOE/ID-11042, Rev. 3, U.S. Department of Energy Idaho Operations Office, June 2006.

DOE-NE-ID, 2005, Site Completion Report for Area CPP-67, WAG 3, OU 3-13, Group 3, Other Surface Soils, DOE/NE-ID-11234, Rev. 0, U.S. Department of Energy Idaho Operations Office, July 2005.

DOE-NE-ID, 2006, Operable Unit 3-14 Tank Farm Soil and Groundwater Remedial Investigation/Baseline Risk Assessment, DOE/NE-ID-11227, Rev. 0, U.S. Department of Energy Idaho Operations Office, April 2006.

EDF-ER-264, 2002, “INEEL CERCLA Disposal Facility Design Inventory,” Rev. 1, Idaho National Engineering and Environmental Laboratory, December 2002. 
EPA, 1988, Guidance for Conducting Remedial Investigations and Feasibility Studies Under CERCLA, Interim Final, EPA/540/G-89/004, U.S. Environmental Protection Agency, October 1988.

EPA, 1989, Methods for Evaluating the Attainment of Cleanup Standards, Volume I: Soils and Solid Media, EPA 230/82-89-042, PB89-234959, U.S. Environmental Protection Agency, February 1989.

EPA, 2000, Close Out Procedures for National Priorities List Sites, EPA 540-R-98-016, OSWER Directive 9320.2-09A-P, PB98-963223, U.S. Environmental Protection Agency, January 2000.

EPA, 2007, Human Health Risk Assessment Risk-Based Concentration Table, http://www.epa.gov/reg3hwmd/risk/human/index.htm, U.S. Environmental Protection Agency, Web page updated May 7, 2007, Web page visited July 2, 2007.

GAI, 1992, Report for the Idaho Chemical Processing Plant Drilling and Sampling Program at Land Disposal Unit CPP-37, prepared by Golder Associates, Inc., for EG\&G Idaho and Westinghouse Idaho Nuclear Company, under Contract No. C90-132739, 903-1161, March 1992.

GDE-7003, 2006, "Levels of Analytical Method Data Validation,” Rev. 4, Idaho Cleanup Project, October 2, 2006.

Hernandez, Nicole K., DOE-ID, to Nicholas Ceto, EPA, and Daryl Koch, DEQ, December 6, 2005 , "Disposal of Contaminated Equipment Associated with Operable Unit 3-13 CERCLA Sites CPP-97, CPP-98, CPP-99 \& CPP-92," FMDP-RFDP-05-136. (NOTE: Access to this record is restricted.)

IC $§ 39-4401$ et seq., 1983, "Hazardous Waste Management Act of 1983," State of Idaho, Idaho Code, 1983.

ICP, 2002, "New Site Identification - Operable Unit 3-13, CPP-37C - Contamination Discovered Southeast of CERCLA Site CPP-37B", Document ID 24750, Idaho Cleanup Project, September 2002.

ICP, 2005, Characterization Results Report for Operable Unit 3-13 Group 3, Other Surface Soils Remediation Set 1 (Phase 1): CPP-92, CPP-98, CPP-99, and CPP-97. ICP/EXT-04-00601, Rev. 0, Idaho Completion Project, February 2005.

ICP, 2006a, Operable Unit 3-13, Group 3, Other Surface Soils, CPP-37B and CPP-37C Characterization Results Report, RPT-175, Idaho Cleanup Project, May 2006.

ICP, 2006b, Data Summary Report for Operable Unit 3-13, Group 3, Other Surface Soils, Remediation Site CPP-97 Confirmation Sampling, RPT-174, Idaho Cleanup Project, February, 2006.

Kirchner, D. R., CH2M-WG Idaho, to R. R. Romine, CH2M-WG Idaho, July 7, 2005a, "Closure Report for ESP-014-05 ICDF Verification Sampling for MP 4529Q - CPP-34A/B,” DRK-047-05.

Kirchner, D. R., CH2M-WG Idaho, to R. L. Davison, CH2M-WG Idaho, November 2, 2005b, "Closure Report for ESP-050-05 ICDF Confirmation Sampling for CPP-34A/B, Sub-Activity \#3," DRK-076-05. 
Kirchner, D. R., Bechtel BWXT Idaho, to R. S. Rice, Bechtel BWXT Idaho, February 15, 2005c, "Closure Report for ESP-116-04 CPP-67 Confirmatory Sampling (INTEC Ponds 1 and 2) Project," ESP-116-04.

LITCO, 1995, Final Preliminary Scoping Track 2 Summary Report for Operable Unit 3-09, INEL-95/0094, Rev. 4, Lockheed Idaho Technology Company, February 1995.

PLN-1662, 2004, "ICDF Verification Sampling-CPP-67 Perc Ponds (ESP-034-04),” Rev. 2, Idaho National Engineering and Environmental Laboratory, Idaho Completion Project, April 2004.

PLN-1739, 2004, “ICDF I-129 Characterization Sampling-CPP-67 Perc Ponds (ESP-062-04),” Rev. 1, Idaho National Engineering and Environmental Laboratory, Idaho Completion Project, August 2004.

PLN-1802, 2004, “ICDF Characterization Sampling, CPP-67 Percolation Pond 1 - Resample (ESP-106-04)," Rev. 0, Idaho National Engineering and Environmental Laboratory, Idaho Completion Project, September 2004.

PLN-1901, 2005, "ICDF I-129 Characterization and Inorganic Verification Sampling for Material Profile 4529Q - CPP-03 and CPP-34A/B Trenches (ESP-014-05)," Rev. 2, Idaho National Laboratory, Idaho Cleanup Project, May 2005.

Rood, S. M., G. A. Harris, and G. J. White, 1995, Background Dose Equivalent Rates and Surficial Soil Metal and Radionuclide Concentrations for the Idaho National Engineering Laboratory, INEL-94/0250, Rev. 0, Idaho National Engineering Laboratory, February 1995.

WINCO, 1993, Track 1 Decision Documentation Package, Site CPP-34, Soil Storage Area in the NE Corner of Idaho Chemical Processing Plant, Operable Unit 3-06, Westinghouse Idaho Nuclear Company, February 1993. 
Appendix A

\section{CPP-03 Characterization Sampling Data}




$$
\text { A-2 }
$$


Appendix A

CPP-03 Characterization Sampling Data

Table A-1. AMP-50 data collected during the characterization sampling effort on Site CPP-03 in the summer of 2006.

\begin{tabular}{|c|c|c|c|c|c|c|c|c|c|c|c|c|c|c|c|c|c|}
\hline \multirow[b]{2}{*}{ Grid \# } & \multirow[b]{2}{*}{$\begin{array}{c}\text { Overburden } \\
\text { (ft) }\end{array}$} & \multicolumn{3}{|c|}{ 0.5-ft Depth } & \multicolumn{3}{|c|}{ 1-ft Depth } & \multicolumn{3}{|c|}{ 2-ft Depth } & \multicolumn{3}{|c|}{ 3-ft Depth } & \multicolumn{4}{|c|}{ Depth as Shown } \\
\hline & & $\begin{array}{l}\text { Minimum } \\
\text { Reading } \\
\text { (mR/hour) }\end{array}$ & $\begin{array}{c}\text { Average } \\
\text { (mR/hour) }\end{array}$ & $\begin{array}{c}\text { Maximum } \\
\text { Reading } \\
\text { (mR/hour) }\end{array}$ & $\begin{array}{l}\text { Minimum } \\
\text { Reading } \\
\text { (mR/hour) }\end{array}$ & $\begin{array}{c}\text { Average } \\
\text { (mR/hour) }\end{array}$ & $\begin{array}{l}\text { Maximum } \\
\text { Reading } \\
\text { (mR/hour) }\end{array}$ & $\begin{array}{l}\text { Minimum } \\
\text { Reading } \\
\text { (mR/hour) }\end{array}$ & $\begin{array}{c}\text { Average } \\
\text { (mR/hour) }\end{array}$ & $\begin{array}{c}\text { Maximum } \\
\text { Reading } \\
\text { (mR/hour) }\end{array}$ & $\begin{array}{l}\text { Minimum } \\
\text { Reading } \\
\text { (mR/hour) }\end{array}$ & $\begin{array}{c}\text { Average } \\
\text { (mR/hour) }\end{array}$ & $\begin{array}{l}\text { Maximum } \\
\text { Reading } \\
\text { (mR/hour) }\end{array}$ & Depth & $\begin{array}{c}\text { Minimum } \\
\text { Reading } \\
\text { (mR/hour) }\end{array}$ & $\begin{array}{c}\text { Average } \\
\text { (mR/hour) }\end{array}$ & $\begin{array}{l}\text { Maximum } \\
\text { Reading } \\
\text { (mR/hour) }\end{array}$ \\
\hline 1 & 1.5 & 0.022 & 0.0245 & 0.027 & 0.022 & 0.0255 & 0.029 & 0.02 & 0.0215 & 0.023 & $-^{a}$ & - & - & $3.5 \mathrm{ft}$ & 0.032 & 0.028 & 0.034 \\
\hline 2 & 1.75 & 0.025 & 0.0275 & 0.03 & 0.024 & 0.0255 & 0.027 & 0.02 & 0.022 & 0.024 & - & - & - & - & - & - & - \\
\hline 3 & 1.25 & 0.029 & 0.0375 & 0.046 & 0.021 & 0.0225 & 0.024 & 0.022 & 0.0245 & 0.027 & 0.024 & 0.026 & 0.028 & - & - & - & - \\
\hline 4 & 1 & 0.159 & 0.1705 & 0.182 & 0.198 & 0.221 & 0.244 & 0.022 & 0.028 & 0.034 & 0.018 & 0.0225 & 0.027 & 8 in. & 0.181 & 0.028 & 0.215 \\
\hline 4 & 1 & - & - & - & - & - & - & - & - & - & - & - & - & $10 \mathrm{in.}$ & 0.259 & 0.028 & 0.299 \\
\hline 4 & 1 & - & - & - & - & - & - & - & - & - & - & - & - & $14 \mathrm{in.}$ & 0.173 & 0.028 & 0.211 \\
\hline 4 & 1 & - & - & - & - & - & - & - & - & - & - & - & - & 16 in. & 0.15 & 0.028 & 0.182 \\
\hline 4 (dup) & 1 & - & - & - & - & - & - & 0.236 & 0.132 & 0.028 & - & - & - & - & - & - & - \\
\hline $4 \mathrm{~N}$ & 1 & 0.034 & 0.0365 & 0.039 & 0.028 & 0.031 & 0.034 & 0.019 & 0.021 & 0.023 & 0.019 & 0.0215 & 0.024 & - & - & - & - \\
\hline $4 \mathrm{~S}$ & 1 & 0.024 & 0.0265 & 0.029 & 0.023 & 0.0255 & 0.028 & 0.033 & 0.035 & 0.037 & 0.038 & 0.041 & 0.044 & - & - & - & - \\
\hline $4 \mathrm{E}$ & 1 & 0.036 & 0.0405 & 0.045 & 0.023 & 0.0275 & 0.032 & 0.02 & 0.022 & 0.024 & 0.02 & 0.0225 & 0.025 & - & - & - & - \\
\hline $4 \mathrm{~W}$ & 1 & 0.032 & 0.0345 & 0.037 & 0.08 & 0.0855 & 0.091 & 0.036 & 0.04 & 0.044 & 0.02 & 0.023 & 0.026 & - & - & - & - \\
\hline 5 & 1 & 0.018 & 0.0215 & 0.025 & 0.02 & 0.022 & 0.024 & 0.021 & 0.0235 & 0.026 & 0.02 & 0.022 & 0.024 & - & - & - & - \\
\hline 6 & 0.5 & 0.027 & 0.0295 & 0.032 & 0.024 & 0.028 & 0.032 & 0.024 & 0.0255 & 0.027 & 0.019 & 0.0225 & 0.026 & - & - & - & - \\
\hline 7 & 0 & 0.024 & 0.0265 & 0.029 & 0.023 & 0.026 & 0.029 & 0.024 & 0.027 & 0.03 & 0.02 & 0.022 & 0.024 & - & - & - & - \\
\hline 8 & 0 & 0.024 & 0.026 & 0.028 & 0.032 & 0.035 & 0.038 & 0.031 & 0.035 & 0.039 & 0.023 & 0.0255 & 0.028 & - & - & - & - \\
\hline 9 & 0 & 0.034 & 0.0375 & 0.041 & 0.027 & 0.0315 & 0.036 & 0.027 & 0.029 & 0.031 & 0.021 & 0.0245 & 0.028 & - & - & - & - \\
\hline 10 & 0 & 0.028 & 0.0305 & 0.033 & 0.026 & 0.0295 & 0.033 & 0.045 & 0.0475 & 0.05 & 0.026 & 0.0295 & 0.033 & - & - & - & - \\
\hline 11 & 0 & 0.032 & 0.0355 & 0.039 & 0.028 & 0.032 & 0.036 & 0.149 & 0.156 & 0.163 & 0.026 & 0.0335 & 0.041 & - & - & - & - \\
\hline 12 & 0 & 0.026 & 0.029 & 0.032 & 0.038 & 0.0395 & 0.041 & 0.246 & 0.267 & 0.288 & 0.036 & 0.04 & 0.044 & - & - & - & - \\
\hline $12 \mathrm{~N}$ & 0 & 0.051 & 0.0585 & 0.066 & 0.103 & 0.1105 & 0.118 & 1.74 & 1.81 & 1.88 & 0.084 & 0.0925 & 0.101 & 38 in. & 0.07 & 0.028 & 0.084 \\
\hline $12 \mathrm{~N}$ & 0 & 0.057 & 0.0605 & 0.064 & 0.034 & 0.037 & 0.04 & 0.025 & 0.027 & 0.029 & 0.022 & 0.024 & 0.026 & - & - & - & - \\
\hline $12 \mathrm{~S}$ & 0 & 0.024 & 0.0265 & 0.029 & 0.03 & 0.036 & 0.042 & 0.078 & 0.085 & 0.092 & 0.024 & 0.026 & 0.028 & - & - & - & - \\
\hline $12 \mathrm{E}$ & 0 & 0.026 & 0.029 & 0.032 & 0.023 & 0.027 & 0.031 & 0.044 & 0.047 & 0.05 & 0.026 & 0.029 & 0.032 & - & - & - & - \\
\hline $12 \mathrm{~W}$ & 0 & 0.028 & 0.031 & 0.034 & 0.022 & 0.025 & 0.028 & 0.038 & 0.0415 & 0.045 & 0.032 & 0.035 & 0.038 & - & - & - & - \\
\hline 13 & 0 & 0.048 & 0.049 & 0.05 & 0.024 & 0.027 & 0.03 & 0.022 & 0.0255 & 0.029 & 0.02 & 0.025 & 0.03 & - & - & - & - \\
\hline 14 & 2 & 0.021 & 0.0235 & 0.026 & 0.023 & 0.0255 & 0.028 & 0.023 & 0.026 & 0.029 & Too sha & $V_{N}$ (hole parti & filled) & - & - & - & - \\
\hline 15 & 1.75 & 0.025 & 0.027 & 0.029 & 0.028 & 0.03 & 0.032 & 0.022 & 0.024 & 0.026 & 0.019 & 0.0215 & 0.024 & - & - & - & - \\
\hline 16 & 1 & 0.043 & 0.0455 & 0.048 & 0.043 & 0.045 & 0.047 & 0.022 & 0.0235 & 0.025 & 0.023 & 0.025 & 0.027 & - & - & - & - \\
\hline 17 & 0.5 & 0.023 & 0.025 & 0.027 & 0.027 & 0.0285 & 0.03 & 0.023 & 0.025 & 0.027 & 0.023 & 0.025 & 0.027 & - & - & - & - \\
\hline 18 & 0.5 & 0.03 & 0.032 & 0.034 & 0.061 & 0.0645 & 0.068 & 0.49 & 0.5175 & 0.545 & 0.61 & 0.633 & 0.656 & - & - & - & - \\
\hline 19 & 0.5 & 0.028 & 0.031 & 0.034 & 0.03 & 0.032 & 0.034 & 0.021 & 0.024 & 0.027 & 0.021 & 0.024 & 0.027 & - & - & - & - \\
\hline 20 & 0 & 0.024 & 0.0275 & 0.031 & 0.025 & 0.0285 & 0.032 & 0.021 & 0.024 & 0.027 & 0.021 & 0.024 & 0.027 & - & - & - & - \\
\hline 21 & 0 & 0.024 & 0.029 & 0.034 & 0.024 & 0.0275 & 0.031 & 0.028 & 0.032 & 0.036 & 0.017 & 0.021 & 0.025 & - & - & - & - \\
\hline 22 & 0 & 0.033 & 0.0355 & 0.038 & 0.048 & 0.0535 & 0.059 & 0.052 & 0.057 & 0.062 & 0.024 & 0.0275 & 0.031 & - & - & - & - \\
\hline
\end{tabular}


Table A-1. (continued).

\begin{tabular}{|c|c|c|c|c|c|c|c|c|c|c|c|c|c|c|c|c|c|}
\hline \multirow[b]{2}{*}{ Grid \# } & \multirow[b]{2}{*}{$\begin{array}{l}\text { Overburden } \\
\text { (ft) }\end{array}$} & \multicolumn{3}{|c|}{0.5 -ft Depth } & \multicolumn{3}{|c|}{ 1-ft Depth } & \multicolumn{3}{|c|}{ 2-ft Depth } & \multicolumn{3}{|c|}{ 3-ft Depth } & \multicolumn{4}{|c|}{ Depth as Shown } \\
\hline & & $\begin{array}{l}\text { Minimum } \\
\text { Reading } \\
\text { (mR/hour) }\end{array}$ & $\begin{array}{c}\text { Average } \\
\text { (mR/hour) }\end{array}$ & $\begin{array}{c}\text { Maximum } \\
\text { Reading } \\
\text { (mR/hour) }\end{array}$ & $\begin{array}{c}\text { Minimum } \\
\text { Reading } \\
\text { (mR/hour) }\end{array}$ & $\begin{array}{c}\text { Average } \\
\text { (mR/hour) }\end{array}$ & $\begin{array}{c}\text { Maximum } \\
\text { Reading } \\
\text { (mR/hour) }\end{array}$ & $\begin{array}{c}\text { Minimum } \\
\text { Reading } \\
\text { (mR/hour) }\end{array}$ & $\begin{array}{c}\text { Average } \\
\text { (mR/hour) }\end{array}$ & $\begin{array}{c}\text { Maximum } \\
\text { Reading } \\
(\mathrm{mR} / \mathrm{hour})\end{array}$ & $\begin{array}{l}\text { Minimum } \\
\text { Reading } \\
\text { (mR/hour) }\end{array}$ & $\begin{array}{c}\text { Average } \\
\text { (mR/hour) }\end{array}$ & $\begin{array}{l}\text { Maximum } \\
\text { Reading } \\
\text { (mR/hour) }\end{array}$ & Depth & $\begin{array}{l}\text { Minimum } \\
\text { Reading } \\
\text { (mR/hour) }\end{array}$ & $\begin{array}{c}\text { Average } \\
\text { (mR/hour) }\end{array}$ & $\begin{array}{l}\text { Maximum } \\
\text { Reading } \\
\text { (mR/hour) }\end{array}$ \\
\hline 23 & 0 & 0.027 & 0.0305 & 0.034 & 0.04 & 0.0445 & 0.049 & 0.054 & 0.0575 & 0.061 & 0.034 & 0.035 & 0.036 & - & - & - & - \\
\hline 24 & 0 & 0.05 & 0.0545 & 0.059 & 0.028 & 0.0315 & 0.035 & 0.049 & 0.054 & 0.059 & 0.024 & 0.026 & 0.028 & - & - & - & - \\
\hline 25 & 0 & 0.024 & 0.027 & 0.03 & 0.021 & 0.0245 & 0.028 & 0.068 & 0.074 & 0.08 & 0.024 & 0.027 & 0.03 & - & - & - & - \\
\hline 26 & 0 & 0.042 & 0.045 & 0.048 & 0.028 & 0.0345 & 0.041 & 0.017 & 0.021 & 0.025 & 0.02 & 0.024 & 0.028 & - & - & - & - \\
\hline 27 & 0 & 0.027 & 0.0295 & 0.032 & 0.023 & 0.0255 & 0.028 & 0.021 & 0.0245 & 0.028 & 0.021 & 0.023 & 0.025 & - & - & - & - \\
\hline 28 & 0 & 0.027 & 0.0285 & 0.03 & 0.026 & 0.0285 & 0.031 & 0.02 & 0.0235 & 0.027 & 0.026 & 0.0285 & 0.031 & - & - & - & - \\
\hline 29 & 0 & 0.028 & 0.03 & 0.032 & 0.034 & 0.036 & 0.038 & 0.024 & 0.0255 & 0.027 & 0.022 & 0.0235 & 0.025 & - & - & - & - \\
\hline 30 & 0 & 0.033 & 0.035 & 0.037 & 0.036 & 0.039 & 0.042 & 0.023 & 0.0255 & 0.028 & 0.026 & 0.0295 & 0.033 & - & - & - & - \\
\hline 31 & 0 & 0.033 & 0.036 & 0.039 & 0.025 & 0.027 & 0.029 & 0.02 & 0.0215 & 0.023 & 0.022 & 0.0235 & 0.025 & - & - & - & - \\
\hline 32 & 0 & 0.038 & 0.047 & 0.056 & 0.084 & 0.094 & 0.104 & 0.024 & 0.026 & 0.028 & 0.022 & 0.025 & 0.028 & $10 \mathrm{in.}$ & 0.063 & 0.028 & 0.068 \\
\hline 32 & 0 & - & - & - & - & - & - & - & - & - & - & - & - & $18 \mathrm{in.}$ & 0.043 & 0.028 & 0.046 \\
\hline 32 (dup) & 0 & - & - & - & 0.078 & 0.0835 & 0.089 & - & - & - & - & - & - & - & - & - & - \\
\hline $32 \mathrm{~N}$ & 0 & 0.024 & 0.0275 & 0.031 & 0.023 & 0.0265 & 0.03 & 0.025 & 0.028 & 0.031 & 0.018 & 0.0215 & 0.025 & - & - & - & - \\
\hline $32 \mathrm{~S}$ & 0 & 0.028 & 0.0325 & 0.037 & 0.024 & 0.027 & 0.03 & 0.02 & 0.022 & 0.024 & 0.025 & 0.028 & 0.031 & - & - & - & - \\
\hline $32 \mathrm{E}$ & 0 & 0.029 & 0.0315 & 0.034 & 0.021 & 0.0235 & 0.026 & 0.021 & 0.0235 & 0.026 & 0.018 & 0.0205 & 0.023 & - & - & - & - \\
\hline $32 \mathrm{~W}$ & 0 & 0.106 & 0.116 & 0.126 & 0.036 & 0.0395 & 0.043 & 0.021 & 0.0225 & 0.024 & 0.021 & 0.0245 & 0.028 & - & - & - & - \\
\hline 33 & 0 & 0.039 & 0.0415 & 0.044 & 0.036 & 0.04 & 0.044 & 0.02 & 0.0235 & 0.027 & 0.025 & 0.029 & 0.033 & - & - & - & - \\
\hline 34 & 0 & 0.027 & 0.0295 & 0.032 & 0.026 & 0.028 & 0.03 & 0.021 & 0.0235 & 0.026 & 0.024 & 0.0255 & 0.027 & - & - & - & - \\
\hline 35 & 0 & 0.031 & 0.0345 & 0.038 & 0.031 & 0.032 & 0.033 & 0.028 & 0.0305 & 0.033 & 0.023 & 0.024 & 0.025 & - & - & - & - \\
\hline 36 & 0 & 0.069 & 0.076 & 0.083 & 0.05 & 0.0535 & 0.057 & 0.022 & 0.0235 & 0.025 & 0.02 & 0.0225 & 0.025 & - & - & - & - \\
\hline 37 & 0 & 0.022 & 0.0235 & 0.025 & 0.026 & 0.027 & 0.028 & 0.023 & 0.0265 & 0.03 & 0.018 & 0.02 & 0.022 & - & - & - & - \\
\hline 38 & 0 & 0.031 & 0.033 & 0.035 & 0.03 & 0.0325 & 0.035 & 0.023 & 0.0255 & 0.028 & 0.02 & 0.0235 & 0.027 & - & - & - & - \\
\hline 39 & 0 & 0.023 & 0.028 & 0.033 & 0.032 & 0.0365 & 0.041 & 0.029 & 0.031 & 0.033 & 0.022 & 0.024 & 0.026 & - & - & - & - \\
\hline
\end{tabular}


Table A-2. Soil data collected during the characterization sampling effort on Site CPP-03 in the summer of 2006.

\begin{tabular}{|c|c|c|c|c|c|c|c|}
\hline $\begin{array}{c}\text { Grid } \\
\text { Location }\end{array}$ & $\begin{array}{l}\text { Depth } \\
\text { (ft) }\end{array}$ & $\begin{array}{c}\text { Lab } \\
\text { Sample } \\
\text { ID }\end{array}$ & Field Sample ID & Method & $\begin{array}{l}\text { Results } \\
(\mathrm{pCi} / \mathrm{g})\end{array}$ & $\begin{array}{l}\text { Error } \\
(\mathrm{pCi} / \mathrm{g})\end{array}$ & $\mathrm{MDL}^{\mathrm{a}}$ \\
\hline 3 & 0.5 & $6 \mathrm{BF} 56$ & CPP-03-3-6 & 3993 & $1.56 \mathrm{E}+00$ & $\pm 1.6 \mathrm{E}-01$ & $-^{\mathrm{b}}$ \\
\hline 4 & 0.5 & 6BF77 & 3RA00103001R5 & 3993 & $6.59 \mathrm{E}+01$ & $\pm 6.0 \mathrm{E}+00$ & - \\
\hline 4 & 1 & 6BF78 & 3RA00103101R5 & 3993 & $2.06 \mathrm{E}+01$ & $\pm 1.6 \mathrm{E}+00$ & - \\
\hline 4 & 2 & 6BF79 & 3RA00103201R5 & 3993 & $<2.9 \mathrm{E}-01$ & - & - \\
\hline 4 & 3 & $6 \mathrm{BF} 80$ & 3RA00103301R5 & 3993 & $<1.9 \mathrm{E}-01$ & - & - \\
\hline 4 & 1 & 6BG29 & 3RA00103102R5 & 3993 & $1.70 \mathrm{E}+01$ & $\pm 2.1 \mathrm{E}+00$ & - \\
\hline 4 & 1 & 6BG30 & 3RA00103103R5 & 3993 & $2.10 \mathrm{E}+01$ & $\pm 2.0 \mathrm{E}+00$ & - \\
\hline 5 & 0.5 & 6BF75 & 3RA00101801R5 & 3993 & $1.66 \mathrm{E}+00$ & $\pm 1.9 \mathrm{E}-01$ & - \\
\hline 7 & 0.5 & 6BF76 & 3RA00101101R5 & 3993 & $2.51 \mathrm{E}-01$ & $\pm 1.9 \mathrm{E}-01$ & - \\
\hline 9 & 1 & $6 \mathrm{BG} 59$ & 3RA00101501R5 & 3993 & $1.41 \mathrm{E}+00$ & $\pm 1.23 \mathrm{E}-00$ & - \\
\hline 10 & 1 & $6 \mathrm{BG} 58$ & 3RA00101701R5 & 3993 & $6.85 \mathrm{E}+00$ & $\pm 5.3 \mathrm{E}-01$ & - \\
\hline 10 & 2 & $6 \mathrm{BJ} 93$ & 3RA00105701R5 & 3993 & $1.82 \mathrm{E}+01$ & $\pm 8.8 \mathrm{E}-01$ & $1.56 \mathrm{E}-01$ \\
\hline 11 & 0.5 & 6BG24 & 3RA00102401R5 & 3993 & $7.24 \mathrm{E}+00$ & $\pm 7.9 \mathrm{E}-01$ & - \\
\hline 11 & 1 & $6 \mathrm{BG} 25$ & 3RA00103401R5 & 3993 & $1.23 \mathrm{E}+02$ & $\pm 9.6 \mathrm{E}+00$ & - \\
\hline 11 & 2 & $6 \mathrm{BG} 26$ & 3RA00103501R5 & 3993 & $1.07 \mathrm{E}+01$ & $\pm 9.2 \mathrm{E}-01$ & - \\
\hline 12 & 2 & 6BF81 & 3RA00101301R5 & 3993 & $9.21 \mathrm{E}+01$ & $\pm 6.4 \mathrm{E}+00$ & - \\
\hline 12 & 2 & $6 \mathrm{BG} 27$ & 3RA00101301R5 & 3993 & $7.37 \mathrm{E}+01$ & $\pm 7.2 \mathrm{E}+00$ & - \\
\hline 12 & 2 & $6 \mathrm{BG} 28$ & 3RA00101302R5 & 3993 & $8.31 \mathrm{E}+01$ & $\pm 7.7 \mathrm{E}+00$ & - \\
\hline 16 & 2 & 6BG56 & 3RA00102201R5 & 3993 & $<3.1 \mathrm{E}-01$ & - & - \\
\hline 17 & 2 & $6 \mathrm{BF} 55$ & СРP-03-17-24 & 3993 & $<2.1 \mathrm{E}-01$ & - & - \\
\hline 19 & 0.5 & $6 \mathrm{BF} 53$ & CPP-03-19-6 & 3993 & $6.88 \mathrm{E}-01$ & $\pm 7.1 \mathrm{E}-02$ & - \\
\hline 22 & 0.5 & 6BJ90 & 3RA00105501R5 & 3993 & $2.67 \mathrm{E}+01$ & $\pm 1.1 \mathrm{E}+00$ & $1.78 \mathrm{E}-01$ \\
\hline 23 & 2 & $6 \mathrm{BJ} 87$ & 3RA00105201R5 & 3993 & $9.11 \mathrm{E}+00$ & $\pm 1.2 \mathrm{E}+00$ & $2.42 \mathrm{E}-01$ \\
\hline 24 & 3 & $6 \mathrm{BG} 62$ & 3RA00103601R5 & 3993 & $<3.9 \mathrm{E}-01$ & - & - \\
\hline 24 & 2 & $6 \mathrm{BJ} 86$ & 3RA00105101R5 & 3993 & $1.63 \mathrm{E}+01$ & $\pm 1.1 \mathrm{E}+00$ & $1.75 \mathrm{E}-01$ \\
\hline 25 & 2 & $6 \mathrm{BJ} 88$ & 3RA00105301R5 & 3993 & $2.98 \mathrm{E}+01$ & $\pm 1.9 \mathrm{E}+00$ & $2.00 \mathrm{E}-01$ \\
\hline 28 & 2 & $6 \mathrm{BF} 73$ & 3RA00102501R5 & 3993 & $2.1 \mathrm{E}-01$ & - & - \\
\hline 29 & 3 & 6BF74 & 3RA00101901R5 & 3993 & $<2.2 \mathrm{E}-01$ & - & - \\
\hline 30 & 2 & $6 \mathrm{BF} 54$ & CPP-03-30-2 & 3993 & $2.69 \mathrm{E}-01$ & $\pm 7.9 \mathrm{E}-02$ & - \\
\hline 32 & 1 & 6BJ95 & 3RA00105901R5 & 3993 & $4.14 \mathrm{E}+01$ & $\pm 1.9 \mathrm{E}+00$ & $1.94 \mathrm{E}-01$ \\
\hline 33 & 2 & $6 \mathrm{BG} 57$ & 3RA00101001R5 & 3993 & $<3.8 \mathrm{E}-01$ & - & 一 \\
\hline 34 & 1 & 6BG61 & 3RA00102901R5 & 3993 & $<4.6 \mathrm{E}-01$ & - & - \\
\hline 36 & 3 & $6 \mathrm{BG} 23$ & 3RA00102801R5 & 3993 & $<2.1 \mathrm{E}-01$ & - & - \\
\hline 36 & 0.5 & 6BJ89 & 3RA00105401R5 & 3993 & $1.46 \mathrm{E}+02$ & $\pm 8.1 \mathrm{E}+00$ & $3.15 \mathrm{E}-01$ \\
\hline 39 & 0.5 & 6BG60 & 3RA001023001R5 & 3993 & $1.73 \mathrm{E}+00$ & $\pm 1.33 \mathrm{E}-01$ & - \\
\hline $11-\mathrm{N}$ & 2 & 6BJ96 & 3RA00106001R5 & 3993 & $1.41 \mathrm{E}+00$ & $\pm 1.3 \mathrm{E}-00$ & $1.92 \mathrm{E}-01$ \\
\hline $11-\mathrm{S}$ & 2 & 6BJ98 & 3RA00106201R5 & 3993 & $1.27 \mathrm{E}+02$ & $\pm 4.9 \mathrm{E}+00$ & 2.89E-01 \\
\hline
\end{tabular}


Table A-2. (continued).

\begin{tabular}{|c|c|c|c|c|c|c|c|}
\hline $\begin{array}{c}\text { Grid } \\
\text { Location } \\
\end{array}$ & $\begin{array}{c}\text { Depth } \\
\text { (ft) }\end{array}$ & $\begin{array}{c}\text { Lab } \\
\text { Sample } \\
\text { ID }\end{array}$ & Field Sample ID & Method & $\begin{array}{l}\text { Results } \\
(\mathrm{pCi} / \mathrm{g})\end{array}$ & $\begin{array}{c}\text { Error } \\
(\mathrm{pCi} / \mathrm{g})\end{array}$ & $\mathrm{MDL}^{\mathrm{a}}$ \\
\hline $11-\mathrm{W}$ & 2 & 6BJ94 & 3RA00105801R5 & 3993 & $4.64 \mathrm{E}+01$ & $\pm 1.8 \mathrm{E}+00$ & $1.69 \mathrm{E}-01$ \\
\hline $12-\mathrm{S}$ & 2 & 6BJ91 & 3RA00105601R5 & 3993 & $1.33 \mathrm{E}+02$ & $\pm 5.5 \mathrm{E}+00$ & $2.84 \mathrm{E}-01$ \\
\hline $12-\mathrm{S}$ & 2 & $6 \mathrm{BJ} 92$ & 3RA00105602R5 & 3993 & $1.19 \mathrm{E}+02$ & $\pm 4.5 \mathrm{E}+00$ & $2.77 \mathrm{E}-01$ \\
\hline $32-W$ & 0.5 & $6 \mathrm{BJ} 97$ & 3RA00106101R5 & 3993 & $7.93 \mathrm{E}+01$ & $\pm 3.1 \mathrm{E}+00$ & $2.03 \mathrm{E}-01$ \\
\hline $4-\mathrm{W}$ & 1 & $6 \mathrm{BJ} 85$ & 3RA00105001R5 & 3993 & $7.09 \mathrm{E}+01$ & $\pm 3.4 \mathrm{E}+00$ & $2.00 \mathrm{E}-01$ \\
\hline
\end{tabular}


Appendix B

\section{CPP-34A/34B High-Purity Germanium Data}


B-2 


\section{Appendix B}

\section{CPP-34A/34B High-Purity Germanium Data}

Table B-1. High-purity germanium data results for CPP-34A/34B. Bold values exceeded the remediation goal of $23 \mathrm{pCi} / \mathrm{g}$ for Cs-137. Measurements taken after excavation of those areas are shown immediately below them. The new locations were slightly off from the original since the physical markers were removed during the excavation.

\begin{tabular}{|c|c|c|c|c|c|}
\hline Elevation & $\begin{array}{l}\text { Sampling } \\
\text { Point ID }\end{array}$ & $\begin{array}{l}\text { Cs-137 } \\
(\mathrm{pCi} / \mathrm{g})\end{array}$ & $\begin{array}{c}2 \sigma \text { Uncertainty } \\
(\mathrm{pCi} / \mathrm{g})\end{array}$ & $\begin{array}{c}\mathrm{K}-40 \\
(\mathrm{pCi} / \mathrm{g})\end{array}$ & $\begin{array}{c}2 \sigma \text { Uncertainty } \\
(\mathrm{pCi} / \mathrm{g})\end{array}$ \\
\hline 4872.6 & $\mathbf{A 7 0}$ & 110.00 & 1.50 & 16.80 & 0.60 \\
\hline$-^{\mathrm{a}}$ & A76 & 2.90 & - & - & - \\
\hline 4872.76 & A71 & 91.10 & 0.70 & 17.50 & 0.90 \\
\hline - & A73 & 5.60 & - & - & - \\
\hline 4876.754 & A6 & 68.10 & 0.90 & 18.30 & 3.80 \\
\hline - & A68 & 6.60 & - & - & - \\
\hline 4875.983 & A7 & 66.40 & 1.10 & 17.80 & 4.10 \\
\hline - & A58 & 4.70 & - & - & - \\
\hline 4870.184 & A43 & 44.30 & 0.90 & 14.70 & 1.20 \\
\hline- & A72 & 1.60 & - & - & - \\
\hline 4870.213 & A44 & 43.20 & 0.80 & 14.00 & 1.10 \\
\hline- & A58 & 4.70 & - & - & - \\
\hline 4869.683 & A40 & 32.80 & 0.30 & 14.90 & 0.70 \\
\hline - & A58A & 8.50 & - & - & - \\
\hline 4869.99 & A41 & 31.20 & 0.70 & 14.10 & 1.20 \\
\hline- & A59 & 16.80 & - & - & - \\
\hline 4869.98 & A69 & 23.60 & 0.50 & 17.60 & 1.30 \\
\hline- & A72 & 1.60 & - & - & - \\
\hline 4868.246 & A10 & 18.90 & 1.20 & 20.20 & 3.20 \\
\hline 4875.467 & A5 & 16.80 & 1.20 & 17.10 & 8.10 \\
\hline 4868.35 & A59 & 16.80 & 0.60 & 14.90 & 1.20 \\
\hline 4854.006 & A16 & 15.70 & 2.50 & 26.20 & 3.20 \\
\hline 4873.657 & A39 & 15.40 & 0.60 & 14.90 & 1.20 \\
\hline 4872.078 & A46 & 13.30 & 0.40 & 15.60 & 1.20 \\
\hline 4871.927 & A38 & 12.10 & 0.40 & 14.90 & 1.20 \\
\hline 4866.592 & A45 & 11.50 & 0.50 & 15.00 & 1.20 \\
\hline 4870.18 & A58 & 8.50 & 0.40 & 14.70 & 0.20 \\
\hline 4870.053 & A35 & 8.50 & 0.40 & 16.30 & 1.40 \\
\hline 4872.133 & A4 & 7.40 & 3.80 & 17.10 & 4.50 \\
\hline 4850.368 & A19 & 7.10 & 3.40 & 21.20 & 6.10 \\
\hline 4855.487 & A50 & 7.00 & 0.40 & 18.50 & 1.20 \\
\hline 4861.843 & A23 & 6.70 & 5.00 & 21.10 & 3.50 \\
\hline 4869.95 & A68 & 6.60 & 0.30 & 17.60 & 1.30 \\
\hline 4863.624 & A9 & 6.39 & 3.00 & 19.90 & 2.00 \\
\hline 4851.474 & A18 & 6.25 & 3.20 & 22.50 & 3.80 \\
\hline
\end{tabular}


Table B-1. (continued).

\begin{tabular}{|c|c|c|c|c|c|}
\hline Elevation & $\begin{array}{l}\text { Sampling } \\
\text { Point ID }\end{array}$ & $\begin{array}{l}\text { Cs-137 } \\
(\mathrm{pCi} / \mathrm{g})\end{array}$ & $\begin{array}{c}2 \sigma \text { Uncertainty } \\
(\mathrm{pCi} / \mathrm{g})\end{array}$ & $\begin{array}{c}\mathrm{K}-40 \\
(\mathrm{pCi} / \mathrm{g})\end{array}$ & $\begin{array}{c}2 \sigma \text { Uncertainty } \\
(\mathrm{pCi} / \mathrm{g})\end{array}$ \\
\hline 4868.51 & A73 & 5.60 & 0.20 & 15.70 & 1.50 \\
\hline 4875.176 & A3 & 5.30 & 3.60 & 17.20 & 5.00 \\
\hline 4860.003 & A55 & 5.30 & 0.30 & 15.90 & 1.10 \\
\hline 4862.787 & A48 & 5.30 & 0.40 & 18.90 & 1.40 \\
\hline 4863.021 & A58 & 4.70 & 0.30 & 17.20 & 1.30 \\
\hline 4858.184 & A11 & 4.70 & 3.90 & 21.80 & 2.70 \\
\hline 4875.994 & $\mathrm{~A} 2$ & 4.60 & 4.10 & 19.50 & 3.90 \\
\hline 4870.8 & A74 & 4.50 & 0.20 & 14.80 & 1.10 \\
\hline 4871.823 & A33 & 4.50 & 6.80 & 18.60 & 3.90 \\
\hline 4873.48 & B8 & 4.00 & 0.10 & 14.90 & 1.00 \\
\hline 4871.48 & B9 & 3.90 & 0.10 & 15.30 & 0.80 \\
\hline 4852.74 & A66 & 3.90 & 0.30 & 19.10 & 1.50 \\
\hline 4855.916 & $\mathrm{~A} 2 \mathrm{O}$ & 3.80 & 7.70 & 22.40 & 3.70 \\
\hline 4858.976 & A14 & 3.60 & 4.80 & 22.20 & 3.10 \\
\hline 4861.37 & A62 & 3.60 & 0.30 & 17.50 & 1.20 \\
\hline 4864.299 & A 15 & 3.50 & 2.70 & 22.10 & 3.30 \\
\hline 4869.91 & A76 & 2.90 & 0.20 & 15.40 & 1.20 \\
\hline 4871.75 & A60 & 2.90 & 0.20 & 15.60 & 0.30 \\
\hline 4875.728 & A1 & 2.87 & 3.00 & 19.20 & 3.80 \\
\hline 4843.952 & $\mathrm{~A} 22$ & 2.80 & 0.30 & 18.10 & 1.40 \\
\hline 4855.791 & A26 & 2.80 & 10.40 & 24.30 & 3.30 \\
\hline 4860.826 & A 25 & 2.80 & 8.00 & 23.30 & 3.40 \\
\hline 4838.489 & A49 & 2.80 & 0.40 & 18.60 & 1.50 \\
\hline 4858.925 & A56 & 2.70 & 0.30 & 17.00 & 1.20 \\
\hline 4857.536 & $\mathrm{~A} 21$ & 2.60 & 8.10 & 22.40 & 4.50 \\
\hline 4856.965 & A52 & 2.50 & 0.10 & 16.80 & 0.70 \\
\hline 4851.98 & A65 & 2.50 & 0.20 & 18.90 & 1.40 \\
\hline 4879.28 & A36 & 2.50 & 0.50 & 15.50 & 1.20 \\
\hline 4866.027 & A8 & 2.40 & 5.50 & 20.20 & 4.40 \\
\hline 4872.47 & $\mathrm{~B} 2$ & 2.30 & 0.10 & 15.10 & 0.90 \\
\hline 4871.561 & A37 & 2.30 & 0.30 & 15.60 & 1.20 \\
\hline 4872.2 & B1 & 2.10 & 0.10 & 15.40 & 0.90 \\
\hline 4858.679 & $\mathrm{~A} 28$ & 2.00 & 8.40 & 21.80 & 3.10 \\
\hline 4860.181 & A53 & 2.00 & 0.30 & 17.00 & 1.30 \\
\hline 4870.57 & A72 & 1.60 & 0.10 & 15.40 & 1.40 \\
\hline 4852.92 & A67 & 1.60 & 0.30 & 19.70 & 1.70 \\
\hline 4856.449 & A51 & 1.60 & 0.30 & 16.90 & 1.10 \\
\hline 4853.816 & $\mathrm{~A} 24$ & 1.50 & 9.30 & 22.00 & 3.50 \\
\hline 4870.23 & B7 & 1.40 & 0.10 & 15.60 & 0.90 \\
\hline 4866.89 & B4 & 1.40 & 0.10 & 14.80 & 0.60 \\
\hline 4873.41 & A61 & 1.30 & 0.70 & 15.70 & 1.20 \\
\hline 4859.9 & A64 & 1.30 & 0.30 & 17.70 & 1.30 \\
\hline
\end{tabular}


Table B-1. (continued).

\begin{tabular}{|c|c|c|c|c|c|}
\hline Elevation & $\begin{array}{l}\text { Sampling } \\
\text { Point ID }\end{array}$ & $\begin{array}{l}\text { Cs-137 } \\
(\mathrm{pCi} / \mathrm{g})\end{array}$ & $\begin{array}{c}2 \sigma \text { Uncertainty } \\
(\mathrm{pCi} / \mathrm{g})\end{array}$ & $\begin{array}{c}\mathrm{K}-40 \\
(\mathrm{pCi} / \mathrm{g})\end{array}$ & $\begin{array}{c}2 \sigma \text { Uncertainty } \\
(\mathrm{pCi} / \mathrm{g})\end{array}$ \\
\hline 4869.595 & A30 & 1.30 & 11.60 & 16.90 & 7.10 \\
\hline 4872.56 & $\mathrm{~B} 10$ & 1.20 & 0.10 & 15.10 & 0.60 \\
\hline 4871.6 & B11 & 1.20 & 0.20 & 15.20 & 0.90 \\
\hline 4869.45 & B5 & 1.10 & 0.10 & 14.70 & 0.80 \\
\hline 4868.89 & A77 & 1.10 & 0.20 & 14.90 & 1.30 \\
\hline 4857.136 & A12 & 1.10 & 14.10 & 22.70 & 3.10 \\
\hline 4861.8 & A63 & 1.10 & 0.30 & 16.10 & 1.20 \\
\hline 4861.596 & A54 & 1.10 & 0.20 & 17.60 & 1.30 \\
\hline 4864.156 & A 31 & 1.10 & 15.80 & 22.00 & 3.80 \\
\hline 4868.399 & A29 & 1.10 & 11.60 & 18.00 & 4.10 \\
\hline 4860.782 & A57 & 1.10 & 0.20 & 16.30 & 1.10 \\
\hline 4872.42 & B15 & 1.00 & 0.10 & 15.00 & 0.80 \\
\hline 4871.68 & B13 & 0.90 & 0.10 & 14.10 & 0.80 \\
\hline 4869.19 & A75 & 0.90 & 0.20 & 14.40 & 1.20 \\
\hline 4856.647 & A13 & 0.90 & 10.60 & 23.00 & 3.10 \\
\hline 4870.47 & B3 & 0.80 & 0.10 & 14.30 & 0.80 \\
\hline 4870.56 & B14 & 0.70 & 0.10 & 14.40 & 1.00 \\
\hline 4870.5 & B6 & 0.70 & 0.10 & 15.00 & 0.80 \\
\hline 4853.084 & A17 & 0.70 & 13.00 & 23.50 & 3.50 \\
\hline 4871.73 & B12 & 0.60 & 0.10 & 14.40 & 0.80 \\
\hline 4854.678 & $\mathrm{~A} 27$ & 0.10 & 17.00 & 3.72 & 3.70 \\
\hline 4872.504 & A32 & 0.10 & 11.00 & 19.00 & 3.70 \\
\hline 4869.524 & A34 & 0.10 & 10.00 & 17.70 & 4.20 \\
\hline
\end{tabular}

Table B-2. CPP-34A/34B high-purity germanium data results from the excavation bottom (e), excavation rim (er), and between the excavations for CPP-34A/34B (s).

\begin{tabular}{lccc}
\hline Elevation & Sampling Point_ID & $\begin{array}{c}\text { Cs-137 } \\
(\mathrm{pCi} / \mathrm{g})\end{array}$ & $\begin{array}{c}2 \sigma \text { Uncertainty } \\
(\mathrm{pCi} / \mathrm{g})\end{array}$ \\
\hline 4870.865 & er1 & 4.37 & 0.24 \\
4870.015 & er2 & 2.37 & 0.2 \\
4873.015 & er3 & 2.2 & 0.18 \\
4868.436 & er4 & 16.3 & 0.46 \\
4869.863 & er5 & 1.12 & 0.11 \\
4869.758 & er6 & 1.88 & 0.12 \\
4872.592 & er7 & 1.16 & 0.16 \\
4870.782 & er8 & 1.27 & 0.12 \\
4870.96 & er9 & 2.8 & 0.16 \\
4873.661 & er10 & 0.66 & 0.16 \\
4874.997 & er1 & $1.77^{\mathrm{a}}$ & 1.1 \\
4873.451 & er12 & 1.86 & 0.17
\end{tabular}


Table B-2. (continued).

\begin{tabular}{|c|c|c|c|}
\hline Elevation & Sampling Point_ID & $\begin{array}{l}\text { Cs-137 } \\
(\mathrm{pCi} / \mathrm{g})\end{array}$ & $\begin{array}{c}2 \sigma \text { Uncertainty } \\
(\mathrm{pCi} / \mathrm{g})\end{array}$ \\
\hline 4872.969 & er13 & 2.54 & 0.16 \\
\hline 4872.51 & er14 & 2.78 & 0.15 \\
\hline 4866.885 & e1 & 4.37 & 0.24 \\
\hline 4866.417 & e2 & 2.37 & 0.2 \\
\hline 4860.154 & e3 & 2.2 & 0.18 \\
\hline 4859.056 & e4 & 0.4 & 0.1 \\
\hline 4858.926 & e5 & 0.4 & 0.1 \\
\hline 4860.178 & e6 & 2.2 & 0.1 \\
\hline 4853.063 & e7 & 1 & 0.1 \\
\hline 4856.63 & e8 & 1 & 0.18 \\
\hline 4855.689 & e9 & 1.77 & 0.17 \\
\hline 4857.178 & e10 & 0.66 & 0.16 \\
\hline 4852.014 & e11 & $1.18^{\mathrm{a}}$ & 1.1 \\
\hline 4854.858 & e12 & 4.1 & 0.2 \\
\hline 4847.634 & e13 & 1 & 1 \\
\hline 4849.329 & e14 & 0.4 & 0.2 \\
\hline 4871.736 & $\mathrm{~s} 1$ & 3.66 & 0.18 \\
\hline 4873.202 & $\mathrm{~s} 2$ & 5.69 & 0.3 \\
\hline 4872.646 & s3 & 3.74 & 0.25 \\
\hline 4872.276 & s4 & 6.04 & 0.32 \\
\hline 4873.199 & s5 & 3.44 & 0.24 \\
\hline 4872.047 & s6 & 3.43 & 0.3 \\
\hline 4873.847 & s7 & 9.64 & 0.27 \\
\hline 4874.244 & s8 & 16.3 & 0.35 \\
\hline \multicolumn{4}{|c|}{ Summary Information ${ }^{\mathrm{a}}$} \\
\hline & Maximum value & 18.90 & \\
\hline & Average & 3.97 & \\
\hline & Standard deviation & 4.14 & \\
\hline & Confidence interval & 0.72 & \\
\hline & $95 \%$ upper confidence level & $4.69^{\mathrm{a}}$ & \\
\hline
\end{tabular}

a. The Cs-137 activity after remediation was complete for points er11 and e11 was erroneously reported in the draft copy of this report. The value reported was $95.3 \mathrm{pCi} / \mathrm{g}$ for each point. The value recorded for e 11 was accurate before remediation was complete, but inaccurate for er11. Both points represented hot spots, which were subsequently remediated further to below the remediation goal. Subsequent gamma scans were collected over the same areas. The sampling supervisor and gamma-scan technician verified that the area was remediated and that the $95.3-\mathrm{pCi} / \mathrm{g}$ value is in error. The actual values cannot be found in the sample logbook, but the gamma-scan technician submitted an e-mail to the project stating the areas in question are in fact below the remediation goal. The technician also suggested averaging the activity from the four closest sampling points surrounding e11 and er11, respectively, and using those values as being representative. The activities from points er9, er10, er12, and e9 were averaged and that value reported herein for er11. Similarly, the activities from points er6, er7, e7, and e10 were averaged and that value reported for e11. The 2-sigma uncertainty was also changed, from 0.99 to 1.1 for each point. (Janikowski, Stuart K. [Stuart.Janikowski@icp.doe.gov], "INTEC information,” to Michael J. Ingram [Michael.Ingram@icp.doe.gov], June 27, 2007, EDMS No.2432620) 
Appendix C

Soil Sampling Results for CPP-67 


$$
\text { C-2 }
$$




\section{Appendix C}

\section{Soil Sampling Results for CPP-67}

Table C-1. ESP-062-04 verification sample results for I- 129 .

\begin{tabular}{|c|c|c|c|c|c|}
\hline Sample ID & Radionuclide & $\begin{array}{l}\text { Sample Value } \\
(\mathrm{pCi} / \mathrm{g})\end{array}$ & $\begin{array}{l}\text { Validation } \\
\text { Flag }\end{array}$ & $\begin{array}{c}\text { Sample } \\
\text { Uncertainty } \\
(\mathrm{pCi} / \mathrm{g})\end{array}$ & $\begin{array}{l}\mathrm{MDA}^{\mathrm{a}} \\
(\mathrm{pCi} / \mathrm{g})\end{array}$ \\
\hline E0620300001RI & I-129 & $6.83 \mathrm{E}-02$ & $(\mathrm{U})$ & $3.98 \mathrm{E}-01$ & $7.66 \mathrm{E}-01$ \\
\hline E0620300101RI & $\mathrm{I}-129$ & $3.86 \mathrm{E}-01$ & $(\mathrm{U})$ & 3.39E-01 & $7.01 \mathrm{E}-01$ \\
\hline E0620300201RI & $\mathrm{I}-129$ & $1.80 \mathrm{E}-02$ & $(\mathrm{U})$ & $3.36 \mathrm{E}-01$ & $6.45 \mathrm{E}-01$ \\
\hline E0620300301RI & $\mathrm{I}-129$ & $2.24 \mathrm{E}-01$ & $(\mathrm{U})$ & $3.28 \mathrm{E}-01$ & $6.61 \mathrm{E}-01$ \\
\hline E0620300401RI & I-129 & $4.46 \mathrm{E}-01$ & $(\mathrm{U})$ & $2.70 \mathrm{E}-01$ & $5.95 \mathrm{E}-01$ \\
\hline E0620300501RI & I-129 & $-1.10 \mathrm{E}-01$ & $(\mathrm{U})$ & $2.55 \mathrm{E}-01$ & 4.75E-01 \\
\hline E0620300601RI & I-129 & 8.92E-02 & $(\mathrm{U})$ & $2.04 \mathrm{E}-01$ & $5.17 \mathrm{E}-01$ \\
\hline E0620300701RI & I-129 & $2.55 \mathrm{E}-01$ & (U) & $2.67 \mathrm{E}-01$ & $5.59 \mathrm{E}-01$ \\
\hline E0620300801RI & $\mathrm{I}-129$ & $9.31 \mathrm{E}-02$ & $(\mathrm{U})$ & $3.95 \mathrm{E}-01$ & $7.68 \mathrm{E}-01$ \\
\hline E0620300901RI & $\mathrm{I}-129$ & $-3.14 \mathrm{E}-02$ & $(\mathrm{U})$ & $3.04 \mathrm{E}-01$ & $5.80 \mathrm{E}-01$ \\
\hline E0620301001RI & $\mathrm{I}-129$ & $8.09 \mathrm{E}-02$ & $(\mathrm{U})$ & $2.03 \mathrm{E}-01$ & $5.20 \mathrm{E}-01$ \\
\hline E0620301101RI & $\mathrm{I}-129$ & $1.06 \mathrm{E}-02$ & $(\mathrm{U})$ & $2.60 \mathrm{E}-01$ & $5.10 \mathrm{E}-01$ \\
\hline E0620301201RI & $\mathrm{I}-129$ & $-1.80 \mathrm{E}-03$ & $(\mathrm{U})$ & 5.12E-01 & $9.65 \mathrm{E}-01$ \\
\hline E0620301301RI & $\mathrm{I}-129$ & $6.72 \mathrm{E}-01$ & $(\mathrm{U})$ & $3.40 \mathrm{E}-01$ & 7.37E-01 \\
\hline E0620301401RI & I-129 & $-3.78 \mathrm{E}-01$ & $(\mathrm{U})$ & $3.23 \mathrm{E}-01$ & 5.64E-01 \\
\hline E0620301501RI & I-129 & $3.15 \mathrm{E}-01$ & $(\mathrm{U})$ & $2.63 \mathrm{E}-01$ & $5.67 \mathrm{E}-01$ \\
\hline E0620301601RI & $\mathrm{I}-129$ & $-3.42 \mathrm{E}-01$ & $(\mathrm{U})$ & $3.61 \mathrm{E}-01$ & $6.31 \mathrm{E}-01$ \\
\hline E0620301701RI & $\mathrm{I}-129$ & $2.15 \mathrm{E}-01$ & $(\mathrm{U})$ & $2.71 \mathrm{E}-01$ & $5.58 \mathrm{E}-01$ \\
\hline E0620301801RI & $\mathrm{I}-129$ & $2.47 \mathrm{E}-01$ & $(\mathrm{U})$ & $3.27 \mathrm{E}-01$ & $6.61 \mathrm{E}-01$ \\
\hline E0620301901RI & $\mathrm{I}-129$ & $2.95 \mathrm{E}-01$ & $(\mathrm{U})$ & $2.51 \mathrm{E}-01$ & $6.49 \mathrm{E}-01$ \\
\hline E0620301902RI & $\mathrm{I}-129$ & $2.73 \mathrm{E}-01$ & $(\mathrm{U})$ & $3.34 \mathrm{E}-01$ & $6.79 \mathrm{E}-01$ \\
\hline E0620302001RI & $\mathrm{I}-129$ & $4.30 \mathrm{E}-01$ & $(\mathrm{U})$ & $2.97 \mathrm{E}-01$ & $6.38 \mathrm{E}-01$ \\
\hline E0620302101RI & $\mathrm{I}-129$ & $2.95 \mathrm{E}-01$ & $(\mathrm{U})$ & $2.41 \mathrm{E}-01$ & $5.23 \mathrm{E}-01$ \\
\hline E0620302201RI & $\mathrm{I}-129$ & $5.15 \mathrm{E}-01$ & $(\mathrm{U})$ & $3.20 \mathrm{E}-01$ & $6.26 \mathrm{E}-01$ \\
\hline E0620302301RI & $\mathrm{I}-129$ & $5.54 \mathrm{E}-01$ & $(\mathrm{U})$ & $3.32 \mathrm{E}-01$ & $7.13 \mathrm{E}-01$ \\
\hline E0620302401RI & $\mathrm{I}-129$ & $-1.93 \mathrm{E}-01$ & $(\mathrm{U})$ & $3.45 \mathrm{E}-01$ & $6.31 \mathrm{E}-01$ \\
\hline E0620302501RI & $\mathrm{I}-129$ & $9.54 \mathrm{E}-02$ & $(\mathrm{U})$ & $2.25 \mathrm{E}-01$ & $4.68 \mathrm{E}-01$ \\
\hline E0620302601RI & $\mathrm{I}-129$ & $1.34 \mathrm{E}-01$ & $(\mathrm{U})$ & $2.57 \mathrm{E}-01$ & $5.27 \mathrm{E}-01$ \\
\hline E0620302701RI & $\mathrm{I}-129$ & $1.01 \mathrm{E}-01$ & $(\mathrm{U})$ & $3.18 \mathrm{E}-01$ & $6.27 \mathrm{E}-01$ \\
\hline E0620302801RI & $\mathrm{I}-129$ & 3.69E-01 & $(\mathrm{U})$ & $2.17 \mathrm{E}-01$ & $5.03 \mathrm{E}-01$ \\
\hline E0620302901RI & $\mathrm{I}-129$ & 5.32E-01 & (UJ) & $2.41 \mathrm{E}-01$ & $5.70 \mathrm{E}-01$ \\
\hline E0620303001RI & I-129 & $-1.61 \mathrm{E}-01$ & $(\mathrm{U})$ & $3.00 \mathrm{E}-01$ & $5.51 \mathrm{E}-01$ \\
\hline
\end{tabular}


Table C-1. (continued).

\begin{tabular}{|c|c|c|c|c|c|}
\hline Sample ID & Radionuclide & $\begin{array}{c}\text { Sample Value } \\
(\mathrm{pCi} / \mathrm{g})\end{array}$ & $\begin{array}{c}\text { Validation } \\
\text { Flag } \\
\end{array}$ & $\begin{array}{c}\text { Sample } \\
\text { Uncertainty } \\
(\mathrm{pCi} / \mathrm{g})\end{array}$ & $\begin{array}{l}\mathrm{MDA}^{\mathrm{a}} \\
(\mathrm{pCi} / \mathrm{g})\end{array}$ \\
\hline E0620303101RI & I-129 & $3.52 \mathrm{E}-01$ & $(\mathrm{U})$ & 3.03E-01 & $6.42 \mathrm{E}-01$ \\
\hline E0620303201RI & $\mathrm{I}-129$ & $-5.72 \mathrm{E}-02$ & $(\mathrm{U})$ & $3.01 \mathrm{E}-01$ & $5.74 \mathrm{E}-01$ \\
\hline E0620303301RI & $\mathrm{I}-129$ & $5.06 \mathrm{E}-01$ & $(\mathrm{UJ})$ & $2.43 \mathrm{E}-01$ & $5.70 \mathrm{E}-01$ \\
\hline E0620303401RI & $\mathrm{I}-129$ & 2.32E-01 & $(\mathrm{U})$ & $2.03 \mathrm{E}-01$ & $5.39 \mathrm{E}-01$ \\
\hline E0620303501RI & I-129 & $4.30 \mathrm{E}-01$ & $(\mathrm{U})$ & $2.64 \mathrm{E}-01$ & $5.86 \mathrm{E}-01$ \\
\hline E0620303601RI & I-129 & $-3.21 \mathrm{E}-03$ & $(\mathrm{U})$ & $2.46 \mathrm{E}-01$ & 4.79E-01 \\
\hline E0620303701RI & I-129 & $1.33 \mathrm{E}-01$ & $(\mathrm{U})$ & $2.97 \mathrm{E}-01$ & $5.96 \mathrm{E}-01$ \\
\hline E0620303801RI & I-129 & $-2.55 \mathrm{E}-01$ & (U) & $2.95 \mathrm{E}-01$ & $5.23 \mathrm{E}-01$ \\
\hline E0620303901RI & I-129 & $2.63 \mathrm{E}-01$ & (U) & $3.08 \mathrm{E}-01$ & $6.35 \mathrm{E}-01$ \\
\hline E0620303902RI & $\mathrm{I}-129$ & $1.62 \mathrm{E}-02$ & (U) & $2.52 \mathrm{E}-01$ & $4.95 \mathrm{E}-01$ \\
\hline E0620304001RI & I-129 & $-1.31 \mathrm{E}-02$ & (U) & $2.97 \mathrm{E}-01$ & $5.75 \mathrm{E}-01$ \\
\hline E0620304101RI & $\mathrm{I}-129$ & $2.53 \mathrm{E}-01$ & $(\mathrm{U})$ & $2.63 \mathrm{E}-01$ & $5.55 \mathrm{E}-01$ \\
\hline E0620304201RI & I-129 & $6.44 \mathrm{E}-01$ & $(\mathrm{UJ})$ & 2.24E-01 & $6.23 \mathrm{E}-01$ \\
\hline E0620304301RI & I-129 & $8.05 \mathrm{E}-02$ & $(\mathrm{U})$ & $2.48 \mathrm{E}-01$ & 4.99E-01 \\
\hline E0620304401RI & I-129 & 8.57E-02 & $(\mathrm{U})$ & $2.49 \mathrm{E}-01$ & $5.03 \mathrm{E}-01$ \\
\hline E0620304501RI & I-129 & $-8.09 \mathrm{E}-02$ & $(\mathrm{U})$ & $2.42 \mathrm{E}-01$ & 4.67E-01 \\
\hline E0620304601RI & I-129 & $1.58 \mathrm{E}-01$ & $(\mathrm{U})$ & $2.13 \mathrm{E}-01$ & 4.54E-01 \\
\hline E0620304701RI & I-129 & $4.23 \mathrm{E}-01$ & $(\mathrm{U})$ & 2.32E-01 & $5.31 \mathrm{E}-01$ \\
\hline E0620304801RI & I-129 & $-5.33 \mathrm{E}-02$ & $(\mathrm{U})$ & $2.71 \mathrm{E}-01$ & $5.21 \mathrm{E}-01$ \\
\hline E0620304901RI & I-129 & $4.80 \mathrm{E}-01$ & (UJ) & $1.74 \mathrm{E}-01$ & $5.05 \mathrm{E}-01$ \\
\hline E0620305001RI & I-129 & $1.57 \mathrm{E}-01$ & $(\mathrm{U})$ & $1.48 \mathrm{E}-01$ & 4.04E-01 \\
\hline E0620305101RI & I-129 & $-5.20 \mathrm{E}-02$ & (U) & $1.65 \mathrm{E}-01$ & 4.09E-01 \\
\hline E0620305201RI & $\mathrm{I}-129$ & $-2.63 \mathrm{E}-01$ & (U) & 2.39E-01 & 4.11E-01 \\
\hline E0620305301RI & I-129 & $1.55 \mathrm{E}-01$ & (U) & $2.35 \mathrm{E}-01$ & $4.93 \mathrm{E}-01$ \\
\hline E0620305401RI & I-129 & 9.39E-02 & (U) & $1.93 \mathrm{E}-01$ & $4.08 \mathrm{E}-01$ \\
\hline E0620305501RI & I-129 & $1.71 \mathrm{E}-01$ & $(\mathrm{U})$ & $2.07 \mathrm{E}-01$ & 4.44E-01 \\
\hline E0620305601RI & I-129 & $3.03 \mathrm{E}-01$ & $(\mathrm{U})$ & $3.55 \mathrm{E}-01$ & $7.20 \mathrm{E}-01$ \\
\hline E0620305701RI & I-129 & $-2.10 \mathrm{E}-01$ & $(\mathrm{U})$ & $2.61 \mathrm{E}-01$ & 4.67E-01 \\
\hline E0620305801RI & $\mathrm{I}-129$ & $-2.70 \mathrm{E}-02$ & $(\mathrm{U})$ & $2.68 \mathrm{E}-01$ & $5.15 \mathrm{E}-01$ \\
\hline E0620305802RI & $\mathrm{I}-129$ & $-8.53 \mathrm{E}-02$ & $(\mathrm{U})$ & $2.71 \mathrm{E}-01$ & $5.12 \mathrm{E}-01$ \\
\hline E0620305901RI & I-129 & $-2.16 \mathrm{E}-01$ & $(\mathrm{U})$ & $3.02 \mathrm{E}-01$ & $5.44 \mathrm{E}-01$ \\
\hline E0620306001RI & I-129 & $-1.15 \mathrm{E}-01$ & $(\mathrm{U})$ & $2.50 \mathrm{E}-01$ & 4.65E-01 \\
\hline E0620306101RI & I-129 & $1.84 \mathrm{E}-01$ & $(\mathrm{U})$ & $2.51 \mathrm{E}-01$ & $5.25 \mathrm{E}-01$ \\
\hline E0620306201RI & I-129 & $-3.90 \mathrm{E}-01$ & $(\mathrm{U})$ & $2.95 \mathrm{E}-01$ & 4.97E-01 \\
\hline E0620306301RI & I-129 & $-2.11 \mathrm{E}-01$ & $(\mathrm{U})$ & $2.66 \mathrm{E}-01$ & 4.74E-01 \\
\hline E0620306401RI & I-129 & $2.91 \mathrm{E}-01$ & (U) & 4.03E-01 & $8.03 \mathrm{E}-01$ \\
\hline E0620306501RI & $\mathrm{I}-129$ & $-2.07 \mathrm{E}-01$ & (U) & $2.29 \mathrm{E}-01$ & 4.04E-01 \\
\hline
\end{tabular}


Table C-1. (continued).

\begin{tabular}{|c|c|c|c|c|c|}
\hline Sample ID & Radionuclide & $\begin{array}{c}\text { Sample Value } \\
(\mathrm{pCi} / \mathrm{g})\end{array}$ & $\begin{array}{c}\text { Validation } \\
\text { Flag } \\
\end{array}$ & $\begin{array}{c}\text { Sample } \\
\text { Uncertainty } \\
(\mathrm{pCi} / \mathrm{g})\end{array}$ & $\begin{array}{l}\mathrm{MDA}^{\mathrm{a}} \\
(\mathrm{pCi} / \mathrm{g})\end{array}$ \\
\hline E0620306601RI & I-129 & $-9.66 \mathrm{E}-02$ & $(\mathrm{U})$ & $2.31 \mathrm{E}-01$ & $4.35 \mathrm{E}-01$ \\
\hline E0620306701RI & $\mathrm{I}-129$ & $4.26 \mathrm{E}-01$ & $(\mathrm{U})$ & $2.93 \mathrm{E}-01$ & $6.30 \mathrm{E}-01$ \\
\hline E0620306801RI & $\mathrm{I}-129$ & 4.35E-01 & $(\mathrm{UJ})$ & $2.02 \mathrm{E}-01$ & $4.90 \mathrm{E}-01$ \\
\hline E0620306802RI & $\mathrm{I}-129$ & $1.85 \mathrm{E}-01$ & $(\mathrm{U})$ & $2.65 \mathrm{E}-01$ & $5.49 \mathrm{E}-01$ \\
\hline E0620306901RI & I-129 & 4.25E-01 & $(\mathrm{UJ})$ & $1.92 \mathrm{E}-01$ & $4.23 \mathrm{E}-01$ \\
\hline E0620307001RI & I-129 & $4.08 \mathrm{E}-01$ & $(\mathrm{U})$ & $2.04 \mathrm{E}-01$ & $4.80 \mathrm{E}-01$ \\
\hline E0620307101RI & I-129 & $1.03 \mathrm{E}-01$ & $(\mathrm{U})$ & $2.90 \mathrm{E}-01$ & $5.78 \mathrm{E}-01$ \\
\hline E0620307201RI & I-129 & $-8.64 \mathrm{E}-01$ & (U) & $2.67 \mathrm{E}-01$ & $5.32 \mathrm{E}-01$ \\
\hline E0620307301RI & I-129 & $5.40 \mathrm{E}-02$ & (U) & $2.58 \mathrm{E}-01$ & $5.13 \mathrm{E}-01$ \\
\hline E0620307401RI & $\mathrm{I}-129$ & $2.46 \mathrm{E}-01$ & (U) & $3.10 \mathrm{E}-01$ & $6.36 \mathrm{E}-01$ \\
\hline E0620307501RI & I-129 & $1.66 \mathrm{E}-01$ & (U) & $2.68 \mathrm{E}-01$ & $5.51 \mathrm{E}-01$ \\
\hline E0620307601RI & $\mathrm{I}-129$ & $-1.79 \mathrm{E}-01$ & $(\mathrm{U})$ & $2.98 \mathrm{E}-01$ & $5.41 \mathrm{E}-01$ \\
\hline E0620307701RI & I-129 & $-1.85 \mathrm{E}-01$ & $(\mathrm{U})$ & $2.74 \mathrm{E}-01$ & 4.93E-01 \\
\hline E0620307801RI & I-129 & $9.41 \mathrm{E}-02$ & $(\mathrm{U})$ & $2.50 \mathrm{E}-01$ & $5.07 \mathrm{E}-01$ \\
\hline E0620307901RI & I-129 & $5.45 \mathrm{E}-02$ & $(\mathrm{U})$ & $3.03 \mathrm{E}-01$ & $5.92 \mathrm{E}-01$ \\
\hline E0620308001RI & I-129 & $1.79 \mathrm{E}-01$ & $(\mathrm{U})$ & $2.98 \mathrm{E}-01$ & $6.07 \mathrm{E}-01$ \\
\hline E0620308101RI & I-129 & $2.72 \mathrm{E}-02$ & $(\mathrm{U})$ & $2.47 \mathrm{E}-01$ & 4.87E-01 \\
\hline E0620308201RI & I-129 & $1.20 \mathrm{E}-03$ & $(\mathrm{U})$ & $3.22 \mathrm{E}-01$ & $6.20 \mathrm{E}-01$ \\
\hline E0620308301RI & I-129 & $2.23 \mathrm{E}-01$ & $(\mathrm{U})$ & $2.12 \mathrm{E}-01$ & 4.67E-01 \\
\hline E0620308401RI & I-129 & $-3.25 \mathrm{E}-01$ & $(\mathrm{U})$ & $2.88 \mathrm{E}-01$ & $5.00 \mathrm{E}-01$ \\
\hline E0620308501RI & I-129 & $-2.39 \mathrm{E}-01$ & $(\mathrm{U})$ & $2.79 \mathrm{E}-01$ & $4.96 \mathrm{E}-01$ \\
\hline E0620308601RI & I-129 & $-2.83 \mathrm{E}-01$ & $(\mathrm{U})$ & $3.12 \mathrm{E}-01$ & $5.49 \mathrm{E}-01$ \\
\hline E0620308701RI & $\mathrm{I}-129$ & $1.43 \mathrm{E}-01$ & (U) & $2.10 \mathrm{E}-01$ & 4.46E- 01 \\
\hline E0620308801RI & I-129 & $1.97 \mathrm{E}-01$ & (U) & $2.08 \mathrm{E}-01$ & $5.43 \mathrm{E}-01$ \\
\hline E0620308901RI & I-129 & 2.29E-01 & (U) & $3.20 \mathrm{E}-01$ & $6.54 \mathrm{E}-01$ \\
\hline E0620309001RI & I-129 & 3.63E-01 & $(\mathrm{U})$ & $2.75 \mathrm{E}-01$ & $5.96 \mathrm{E}-01$ \\
\hline E0620309101RI & I-129 & 4.15E-02 & $(\mathrm{U})$ & $2.60 \mathrm{E}-01$ & $5.15 \mathrm{E}-01$ \\
\hline E0620309201RI & I-129 & $2.65 \mathrm{E}-01$ & $(\mathrm{U})$ & $2.26 \mathrm{E}-01$ & $4.98 \mathrm{E}-01$ \\
\hline E0620309301RI & $\mathrm{I}-129$ & $2.16 \mathrm{E}-02$ & $(\mathrm{U})$ & $3.17 \mathrm{E}-01$ & $6.15 \mathrm{E}-01$ \\
\hline E0620309401RI & $\mathrm{I}-129$ & $-6.00 \mathrm{E}-01$ & $(\mathrm{U})$ & $2.36 \mathrm{E}-01$ & 4.91E-01 \\
\hline E0620309501RI & I-129 & $3.60 \mathrm{E}-02$ & $(\mathrm{U})$ & $2.87 \mathrm{E}-01$ & $5.62 \mathrm{E}-01$ \\
\hline E0620309601RI & I-129 & $3.88 \mathrm{E}-01$ & $(\mathrm{U})$ & $2.31 \mathrm{E}-01$ & $5.24 \mathrm{E}-01$ \\
\hline E0620309701RI & I-129 & $-7.05 \mathrm{E}-01$ & $(\mathrm{U})$ & $3.34 \mathrm{E}-01$ & $5.18 \mathrm{E}-01$ \\
\hline E0620309801RI & I-129 & $2.75 \mathrm{E}-01$ & $(\mathrm{U})$ & $2.24 \mathrm{E}-01$ & 4.98E-01 \\
\hline E0620309901RI & I-129 & $8.66 \mathrm{E}-01$ & (UJ) & $2.78 \mathrm{E}-01$ & $7.58 \mathrm{E}-01$ \\
\hline E0620310001RI & I-129 & $-8.20 \mathrm{E}-02$ & $(\mathrm{U})$ & $1.87 \mathrm{E}-01$ & $5.08 \mathrm{E}-01$ \\
\hline E0620310101RI & $\mathrm{I}-129$ & $1.96 \mathrm{E}-01$ & (U) & $2.91 \mathrm{E}-01$ & $5.98 \mathrm{E}-01$ \\
\hline
\end{tabular}


Table C-1. (continued).

\begin{tabular}{|c|c|c|c|c|c|}
\hline Sample ID & Radionuclide & $\begin{array}{c}\text { Sample Value } \\
(\mathrm{pCi} / \mathrm{g})\end{array}$ & $\begin{array}{c}\text { Validation } \\
\text { Flag } \\
\end{array}$ & $\begin{array}{c}\text { Sample } \\
\text { Uncertainty } \\
(\mathrm{pCi} / \mathrm{g})\end{array}$ & $\begin{array}{l}\mathrm{MDA}^{\mathrm{a}} \\
(\mathrm{pCi} / \mathrm{g})\end{array}$ \\
\hline E0620310201RI & I-129 & $2.18 \mathrm{E}-01$ & $(\mathrm{U})$ & $2.11 \mathrm{E}-01$ & $4.68 \mathrm{E}-01$ \\
\hline E0620310202RI & $\mathrm{I}-129$ & $-1.05 \mathrm{E}-01$ & $(\mathrm{U})$ & $2.59 \mathrm{E}-01$ & $4.83 \mathrm{E}-01$ \\
\hline E0620310301RI & $\mathrm{I}-129$ & $-7.29 \mathrm{E}-02$ & $(\mathrm{U})$ & $2.81 \mathrm{E}-01$ & $5.31 \mathrm{E}-01$ \\
\hline E0620310401RI & $\mathrm{I}-129$ & $2.38 \mathrm{E}-01$ & $(\mathrm{U})$ & $2.99 \mathrm{E}-01$ & $6.16 \mathrm{E}-01$ \\
\hline E0620310501RI & I-129 & $-2.23 \mathrm{E}-01$ & $(\mathrm{U})$ & $2.70 \mathrm{E}-01$ & 4.84E-01 \\
\hline E0620310601RI & I-129 & $-2.62 \mathrm{E}-01$ & $(\mathrm{U})$ & $2.94 \mathrm{E}-01$ & $5.19 \mathrm{E}-01$ \\
\hline E0620310602RI & I-129 & $2.35 \mathrm{E}-01$ & $(\mathrm{U})$ & $2.10 \mathrm{E}-01$ & 4.69E-01 \\
\hline E0620310701RI & I-129 & $3.77 \mathrm{E}-01$ & (U) & $2.71 \mathrm{E}-01$ & $5.90 \mathrm{E}-01$ \\
\hline E0620310801RI & I-129 & $-9.22 \mathrm{E}-02$ & (U) & $3.04 \mathrm{E}-01$ & $5.70 \mathrm{E}-01$ \\
\hline E0620310901RI & $\mathrm{I}-129$ & $2.15 \mathrm{E}-01$ & (U) & $1.96 \mathrm{E}-01$ & 4.34E-01 \\
\hline E0620311001RI & I-129 & $6.88 \mathrm{E}-02$ & (U) & $2.56 \mathrm{E}-01$ & $5.11 \mathrm{E}-01$ \\
\hline E0620311101RI & $\mathrm{I}-129$ & $1.91 \mathrm{E}-01$ & $(\mathrm{U})$ & $2.28 \mathrm{E}-01$ & 4.87E-01 \\
\hline E0620311201RI & I-129 & $2.27 \mathrm{E}-01$ & $(\mathrm{U})$ & $2.35 \mathrm{E}-01$ & $5.03 \mathrm{E}-01$ \\
\hline E0620311301RI & I-129 & $1.27 \mathrm{E}-01$ & $(\mathrm{U})$ & $2.87 \mathrm{E}-01$ & $5.77 \mathrm{E}-01$ \\
\hline E0620311401RI & I-129 & $2.57 \mathrm{E}-02$ & $(\mathrm{U})$ & $2.36 \mathrm{E}-01$ & 4.69E-01 \\
\hline E0620311501RI & I-129 & $3.76 \mathrm{E}-01$ & $(\mathrm{U})$ & $1.97 \mathrm{E}-01$ & $3.83 \mathrm{E}-01$ \\
\hline E0620311601RI & I-129 & $3.27 \mathrm{E}-01$ & $(\mathrm{U})$ & $1.96 \mathrm{E}-01$ & $5.39 \mathrm{E}-01$ \\
\hline E0620311701RI & I-129 & $1.36 \mathrm{E}-01$ & $(\mathrm{U})$ & $2.53 \mathrm{E}-01$ & $5.18 \mathrm{E}-01$ \\
\hline E0620311801RI & I-129 & $3.59 \mathrm{E}-01$ & $(\mathrm{UJ})$ & $1.49 \mathrm{E}-01$ & $3.18 \mathrm{E}-01$ \\
\hline E0620311901RI & I-129 & $3.32 \mathrm{E}-01$ & $(\mathrm{U})$ & $2.57 \mathrm{E}-01$ & $5.57 \mathrm{E}-01$ \\
\hline E0620312001RI & I-129 & $2.01 \mathrm{E}-01$ & $(\mathrm{U})$ & $3.04 \mathrm{E}-01$ & $6.15 \mathrm{E}-01$ \\
\hline E0620312101RI & I-129 & $6.80 \mathrm{E}-02$ & (U) & $3.01 \mathrm{E}-01$ & $5.93 \mathrm{E}-01$ \\
\hline E0620312201RI & $\mathrm{I}-129$ & $1.33 \mathrm{E}-01$ & (U) & 2.09E-01 & $4.41 \mathrm{E}-01$ \\
\hline E0620312301RI & I-129 & $5.12 \mathrm{E}-02$ & (U) & $2.70 \mathrm{E}-01$ & $5.34 \mathrm{E}-01$ \\
\hline E0620312401RI & I-129 & $-2.64 \mathrm{E}-01$ & (U) & $3.29 \mathrm{E}-01$ & $5.89 \mathrm{E}-01$ \\
\hline E0620312501RI & I-129 & $-8.56 \mathrm{E}-02$ & $(\mathrm{U})$ & $2.74 \mathrm{E}-01$ & $5.16 \mathrm{E}-01$ \\
\hline E0620312502RI & I-129 & 7.59E-02 & $(\mathrm{U})$ & $3.16 \mathrm{E}-01$ & $6.21 \mathrm{E}-01$ \\
\hline E0620312601RI & $\mathrm{I}-129$ & $3.65 \mathrm{E}-03$ & $(\mathrm{U})$ & $2.73 \mathrm{E}-01$ & $5.30 \mathrm{E}-01$ \\
\hline E0620312701RI & $\mathrm{I}-129$ & $2.03 \mathrm{E}-01$ & $(\mathrm{U})$ & $3.02 \mathrm{E}-01$ & $6.17 \mathrm{E}-01$ \\
\hline E0620312801RI & $\mathrm{I}-129$ & $4.37 \mathrm{E}-01$ & $(\mathrm{U})$ & $2.23 \mathrm{E}-01$ & $5.24 \mathrm{E}-01$ \\
\hline E0620312901RI & I-129 & $-6.96 \mathrm{E}-02$ & $(\mathrm{U})$ & $2.44 \mathrm{E}-01$ & $5.86 \mathrm{E}-01$ \\
\hline E0620313001RI & I-129 & $-8.57 \mathrm{E}-02$ & $(\mathrm{U})$ & $3.12 \mathrm{E}-01$ & $5.85 \mathrm{E}-01$ \\
\hline E0620313101RI & I-129 & 4.15E-02 & $(\mathrm{U})$ & $2.81 \mathrm{E}-01$ & $5.53 \mathrm{E}-01$ \\
\hline E0620313201RI & I-129 & 4.10E-01 & $(\mathrm{U})$ & $3.13 \mathrm{E}-01$ & $6.65 \mathrm{E}-01$ \\
\hline E0620313301RI & I-129 & $2.83 \mathrm{E}-01$ & $(\mathrm{U})$ & $2.67 \mathrm{E}-01$ & $5.66 \mathrm{E}-01$ \\
\hline E0620313401RI & I-129 & $1.15 \mathrm{E}-01$ & (U) & $2.67 \mathrm{E}-01$ & $5.38 \mathrm{E}-01$ \\
\hline E0620313501RI & $\mathrm{I}-129$ & $3.44 \mathrm{E}-01$ & (U) & $2.56 \mathrm{E}-01$ & $5.61 \mathrm{E}-01$ \\
\hline
\end{tabular}


Table C-1. (continued).

\begin{tabular}{|c|c|c|c|c|c|}
\hline Sample ID & Radionuclide & $\begin{array}{c}\text { Sample Value } \\
(\mathrm{pCi} / \mathrm{g})\end{array}$ & $\begin{array}{c}\text { Validation } \\
\text { Flag } \\
\end{array}$ & $\begin{array}{c}\text { Sample } \\
\text { Uncertainty } \\
(\mathrm{pCi} / \mathrm{g})\end{array}$ & $\begin{array}{l}\mathrm{MDA}^{\mathrm{a}} \\
(\mathrm{pCi} / \mathrm{g})\end{array}$ \\
\hline E0620313601RI & I-129 & $2.84 \mathrm{E}-01$ & $(\mathrm{U})$ & $2.50 \mathrm{E}-01$ & $5.38 \mathrm{E}-01$ \\
\hline E0620313602RI & $\mathrm{I}-129$ & $-1.03 \mathrm{E}-01$ & $(\mathrm{U})$ & $3.14 \mathrm{E}-01$ & $5.87 \mathrm{E}-01$ \\
\hline E0620313701RI & $\mathrm{I}-129$ & $1.63 \mathrm{E}-01$ & $(\mathrm{U})$ & $2.55 \mathrm{E}-01$ & $5.28 \mathrm{E}-01$ \\
\hline E0620313801RI & $\mathrm{I}-129$ & $1.28 \mathrm{E}-01$ & $(\mathrm{U})$ & $2.66 \mathrm{E}-01$ & $5.38 \mathrm{E}-01$ \\
\hline E0620313901RI & I-129 & $4.51 \mathrm{E}-01$ & $(\mathrm{U})$ & $2.42 \mathrm{E}-01$ & $5.48 \mathrm{E}-01$ \\
\hline E0620314001RI & I-129 & $1.88 \mathrm{E}-01$ & $(\mathrm{U})$ & $2.22 \mathrm{E}-01$ & $5.31 \mathrm{E}-01$ \\
\hline E0620314101RI & I-129 & $1.38 \mathrm{E}-01$ & $(\mathrm{U})$ & $2.85 \mathrm{E}-01$ & $5.74 \mathrm{E}-01$ \\
\hline E0620314201RI & I-129 & $5.15 \mathrm{E}-01$ & (U) & $3.09 \mathrm{E}-01$ & $5.52 \mathrm{E}-01$ \\
\hline E0620314301RI & I-129 & $-1.62 \mathrm{E}-01$ & (U) & $3.27 \mathrm{E}-01$ & $6.00 \mathrm{E}-01$ \\
\hline E0620314401RI & $\mathrm{I}-129$ & $1.53 \mathrm{E}-01$ & (U) & $2.35 \mathrm{E}-01$ & $4.90 \mathrm{E}-01$ \\
\hline E0620314501RI & I-129 & $1.18 \mathrm{E}-01$ & (U) & $2.83 \mathrm{E}-01$ & 5.67E-01 \\
\hline E0620314601RI & $\mathrm{I}-129$ & $2.08 \mathrm{E}-01$ & $(\mathrm{U})$ & $2.96 \mathrm{E}-01$ & $6.05 \mathrm{E}-01$ \\
\hline E0620314701RI & I-129 & $3.76 \mathrm{E}-01$ & $(\mathrm{U})$ & $2.47 \mathrm{E}-01$ & $5.52 \mathrm{E}-01$ \\
\hline E0620314801RI & I-129 & $1.98 \mathrm{E}-01$ & $(\mathrm{U})$ & $2.71 \mathrm{E}-01$ & $5.58 \mathrm{E}-01$ \\
\hline E0620314901RI & I-129 & 3.33E-01 & $(\mathrm{U})$ & $2.76 \mathrm{E}-01$ & $5.91 \mathrm{E}-01$ \\
\hline E0620315001RI & I-129 & 5.19E-02 & $(\mathrm{U})$ & $2.92 \mathrm{E}-01$ & $5.75 \mathrm{E}-01$ \\
\hline E0620315101RI & I-129 & $8.14 \mathrm{E}-01$ & $(\mathrm{UJ})$ & $2.39 \mathrm{E}-01$ & $6.10 \mathrm{E}-01$ \\
\hline E0620315201RI & I-129 & $1.31 \mathrm{E}-01$ & $(\mathrm{U})$ & $2.94 \mathrm{E}-01$ & $5.90 \mathrm{E}-01$ \\
\hline E0620315301RI & I-129 & $-2.63 \mathrm{E}-01$ & $(\mathrm{U})$ & $3.01 \mathrm{E}-01$ & $5.44 \mathrm{E}-01$ \\
\hline E0620315401RI & I-129 & $3.40 \mathrm{E}-01$ & $(\mathrm{U})$ & $2.86 \mathrm{E}-01$ & $6.12 \mathrm{E}-01$ \\
\hline E0620315501RI & I-129 & $-2.44 \mathrm{E}-02$ & $(\mathrm{U})$ & $3.25 \mathrm{E}-01$ & $6.18 \mathrm{E}-01$ \\
\hline E0620315601RI & I-129 & $2.50 \mathrm{E}-01$ & $(\mathrm{U})$ & $2.32 \mathrm{E}-01$ & $5.03 \mathrm{E}-01$ \\
\hline E0620315701RI & $\mathrm{I}-129$ & $-3.13 \mathrm{E}-01$ & (U) & $3.20 \mathrm{E}-01$ & $5.60 \mathrm{E}-01$ \\
\hline E0620315801RI & I-129 & $3.90 \mathrm{E}-01$ & (UJ) & $1.78 \mathrm{E}-01$ & 4.49E-01 \\
\hline E0620315901RI & I-129 & $-1.67 \mathrm{E}-01$ & $(\mathrm{U})$ & $3.31 \mathrm{E}-01$ & $6.06 \mathrm{E}-01$ \\
\hline E0620315902RI & I-129 & $4.75 \mathrm{E}-01$ & $(\mathrm{U})$ & 2.62E-01 & $5.90 \mathrm{E}-01$ \\
\hline E0620316001RI & I-129 & 4.39E-01 & $(\mathrm{UJ})$ & $1.79 \mathrm{E}-01$ & 4.63E-01 \\
\hline E0620316101RI & $\mathrm{I}-129$ & $-1.35 \mathrm{E}-01$ & $(\mathrm{U})$ & $2.35 \mathrm{E}-01$ & 4.34E-01 \\
\hline E0620316201RI & $\mathrm{I}-129$ & $1.37 \mathrm{E}-01$ & $(\mathrm{U})$ & $2.36 \mathrm{E}-01$ & 4.89E-01 \\
\hline E0620316301RI & $\mathrm{I}-129$ & $4.26 \mathrm{E}-01$ & $(\mathrm{U})$ & $2.43 \mathrm{E}-01$ & $5.49 \mathrm{E}-01$ \\
\hline E0620316401RI & I-129 & $3.11 \mathrm{E}-01$ & $(\mathrm{U})$ & $2.35 \mathrm{E}-01$ & $5.14 \mathrm{E}-01$ \\
\hline E0620316501RI & I-129 & 7.37E-02 & $(\mathrm{U})$ & $2.60 \mathrm{E}-01$ & $5.20 \mathrm{E}-01$ \\
\hline E0620316601RI & I-129 & $6.30 \mathrm{E}-01$ & (UJ) & $2.58 \mathrm{E}-01$ & $5.98 \mathrm{E}-01$ \\
\hline E0620316701RI & I-129 & 4.63E-02 & $(\mathrm{U})$ & $2.95 \mathrm{E}-01$ & $5.77 \mathrm{E}-01$ \\
\hline E0620316801RI & I-129 & $2.50 \mathrm{E}-01$ & $(\mathrm{U})$ & $2.40 \mathrm{E}-01$ & $5.16 \mathrm{E}-01$ \\
\hline E0620316901RI & I-129 & $2.97 \mathrm{E}-01$ & (U) & $1.71 \mathrm{E}-01$ & 4.07E-01 \\
\hline E0620317001RI & $\mathrm{I}-129$ & $2.80 \mathrm{E}-01$ & (U) & $3.23 \mathrm{E}-01$ & $6.61 \mathrm{E}-01$ \\
\hline
\end{tabular}


Table C-1. (continued).

\begin{tabular}{|c|c|c|c|c|c|}
\hline Sample ID & Radionuclide & $\begin{array}{l}\text { Sample Value } \\
(\mathrm{pCi} / \mathrm{g})\end{array}$ & $\begin{array}{l}\text { Validation } \\
\text { Flag }\end{array}$ & $\begin{array}{c}\text { Sample } \\
\text { Uncertainty } \\
(\mathrm{pCi} / \mathrm{g})\end{array}$ & $\begin{array}{l}\mathrm{MDA}^{\mathrm{a}} \\
(\mathrm{pCi} / \mathrm{g})\end{array}$ \\
\hline E0620317101RI & $\mathrm{I}-129$ & $6.99 \mathrm{E}-01$ & $(\mathrm{UJ})$ & $2.00 \mathrm{E}-01$ & $5.30 \mathrm{E}-01$ \\
\hline E0620317201RI & I-129 & $-1.72 \mathrm{E}-01$ & (U) & $2.37 \mathrm{E}-01$ & $4.36 \mathrm{E}-01$ \\
\hline E0620317301RI & I-129 & $-1.74 \mathrm{E}-02$ & $(\mathrm{U})$ & $2.70 \mathrm{E}-01$ & $5.25 \mathrm{E}-01$ \\
\hline E0620317401RI & I-129 & $4.68 \mathrm{E}-01$ & $(\mathrm{UJ})$ & $1.91 \mathrm{E}-01$ & $4.72 \mathrm{E}-01$ \\
\hline E0620317501RI & I-129 & $2.34 \mathrm{E}-01$ & $(\mathrm{U})$ & $2.46 \mathrm{E}-01$ & $5.21 \mathrm{E}-01$ \\
\hline E0620317601RI & I-129 & $1.31 \mathrm{E}-02$ & $(\mathrm{U})$ & $2.62 \mathrm{E}-01$ & $5.11 \mathrm{E}-01$ \\
\hline E0620317701RI & $\mathrm{I}-129$ & $2.87 \mathrm{E}-01$ & (U) & $2.40 \mathrm{E}-01$ & $5.19 \mathrm{E}-01$ \\
\hline E0620317702RI & I-129 & $3.24 \mathrm{E}-01$ & (U) & $2.99 \mathrm{E}-01$ & $6.27 \mathrm{E}-01$ \\
\hline E0620317801RI & I-129 & $2.28 \mathrm{E}-02$ & (U) & $2.49 \mathrm{E}-01$ & 4.91E-01 \\
\hline E0620317901RI & I-129 & $4.00 \mathrm{E}-01$ & (U) & $2.66 \mathrm{E}-01$ & $5.80 \mathrm{E}-01$ \\
\hline E0620318001RI & I-129 & $2.51 \mathrm{E}-01$ & $(\mathrm{U})$ & $2.59 \mathrm{E}-01$ & $5.47 \mathrm{E}-01$ \\
\hline E0620318101RI & I-129 & $3.15 \mathrm{E}-01$ & $(\mathrm{U})$ & $2.51 \mathrm{E}-01$ & $5.49 \mathrm{E}-01$ \\
\hline E0620318201RI & $\mathrm{I}-129$ & $3.51 \mathrm{E}-01$ & $(\mathrm{U})$ & $2.76 \mathrm{E}-01$ & $5.92 \mathrm{E}-01$ \\
\hline E0620318301RI & $\mathrm{I}-129$ & 4.15E-01 & $(\mathrm{U})$ & $2.81 \mathrm{E}-01$ & $6.14 \mathrm{E}-01$ \\
\hline E0620318302RI & $\mathrm{I}-129$ & $-6.75 \mathrm{E}-02$ & $(\mathrm{U})$ & $2.75 \mathrm{E}-01$ & $5.19 \mathrm{E}-01$ \\
\hline E0620318401RI & I-129 & $2.95 \mathrm{E}-01$ & (UJ) & $1.43 \mathrm{E}-01$ & 3.99E-01 \\
\hline E0620318501RI & I-129 & $1.07 \mathrm{E}-01$ & $(\mathrm{U})$ & $2.39 \mathrm{E}-01$ & 4.89E-01 \\
\hline E0620318601RI & $\mathrm{I}-129$ & $3.71 \mathrm{E}-01$ & $(\mathrm{U})$ & $2.23 \mathrm{E}-01$ & 5.19E-01 \\
\hline E0620318701RI & $\mathrm{I}-129$ & $3.15 \mathrm{E}-01$ & $(\mathrm{U})$ & $2.54 \mathrm{E}-01$ & $5.49 \mathrm{E}-01$ \\
\hline E0620322201RI & $\mathrm{I}-129$ & $3.28 \mathrm{E}-01$ & $(\mathrm{U})$ & $2.02 \mathrm{E}-01$ & $4.68 \mathrm{E}-01$ \\
\hline E0620322301RI & $\mathrm{I}-129$ & 4.13E-01 & $(\mathrm{U})$ & $2.39 \mathrm{E}-01$ & $5.43 \mathrm{E}-01$ \\
\hline E0620322401RI & $\mathrm{I}-129$ & $-3.27 \mathrm{E}-01$ & $(\mathrm{U})$ & $3.43 \mathrm{E}-01$ & $6.07 \mathrm{E}-01$ \\
\hline E0620322501RI & $\mathrm{I}-129$ & $-5.35 \mathrm{E}-02$ & $(\mathrm{U})$ & $2.44 \mathrm{E}-01$ & 4.68E-01 \\
\hline E0620322601RI & $\mathrm{I}-129$ & $3.24 \mathrm{E}-01$ & (U) & $2.06 \mathrm{E}-01$ & $5.54 \mathrm{E}-01$ \\
\hline E0620322701RI & $\mathrm{I}-129$ & $2.30 \mathrm{E}-01$ & (U) & $2.53 \mathrm{E}-01$ & $5.35 \mathrm{E}-01$ \\
\hline E0620323001RI & $\mathrm{I}-129$ & $-1.35 \mathrm{E}-01$ & $(\mathrm{U})$ & $2.95 \mathrm{E}-01$ & $5.49 \mathrm{E}-01$ \\
\hline E0620323301RI & $\mathrm{I}-129$ & $6.15 \mathrm{E}-01$ & $(\mathrm{UJ})$ & $2.57 \mathrm{E}-01$ & $4.95 \mathrm{E}-01$ \\
\hline E0620323401RI & $\mathrm{I}-129$ & $6.75 \mathrm{E}-01$ & (UJ) & $2.50 \mathrm{E}-01$ & $5.98 \mathrm{E}-01$ \\
\hline E0620323501RI & $\mathrm{I}-129$ & $2.19 \mathrm{E}-01$ & $(\mathrm{U})$ & $2.73 \mathrm{E}-01$ & $5.67 \mathrm{E}-01$ \\
\hline E0620323601RI & I-129 & $1.56 \mathrm{E}-01$ & $(\mathrm{U})$ & $2.63 \mathrm{E}-01$ & $5.39 \mathrm{E}-01$ \\
\hline \multicolumn{6}{|c|}{$\begin{array}{l}\mathrm{U}=\text { nondetect. } \\
\mathrm{UJ}=\text { false positive due to concentrations less than the decision level and the minimum detectable concentration associated } \\
\text { with the sample result. }\end{array}$} \\
\hline
\end{tabular}


Table C-2. ESP-106-04 verification resample results for I-129 on CPP-67.

\begin{tabular}{|c|c|c|c|c|c|}
\hline Sample ID & Radionuclide & $\begin{array}{l}\text { Sample Value } \\
(\mathrm{pCi} / \mathrm{g})\end{array}$ & $\begin{array}{c}\text { Validation } \\
\text { Flag } \\
\end{array}$ & $\begin{array}{c}\text { Sample } \\
\text { Uncertainty } \\
(\mathrm{pCi} / \mathrm{g})\end{array}$ & $\begin{array}{l}\mathrm{MDA}^{\mathrm{a}} \\
(\mathrm{pCi} / \mathrm{g})\end{array}$ \\
\hline E1060400001RI & I-129 & $1.86 \mathrm{E}+00$ & & $3.75 \mathrm{E}-01$ & $7.71 \mathrm{E}-01$ \\
\hline E1060400101RI & I-129 & $3.79 \mathrm{E}+00$ & & $4.80 \mathrm{E}-01$ & $1.02 \mathrm{E}+00$ \\
\hline E1060400201RI & $\mathrm{I}-129$ & $6.10 \mathrm{E}+00$ & & $7.14 \mathrm{E}-01$ & $1.26 \mathrm{E}+00$ \\
\hline E1060400301RI & $\mathrm{I}-129$ & $2.21 \mathrm{E}+00$ & & $4.29 \mathrm{E}-01$ & $5.51 \mathrm{E}-01$ \\
\hline E1060400401RI & $\mathrm{I}-129$ & $1.16 \mathrm{E}+00$ & & $3.75 \mathrm{E}-01$ & 4.98E-01 \\
\hline E1060400501RI & $\mathrm{I}-129$ & $7.26 \mathrm{E}+00$ & & $6.79 \mathrm{E}-01$ & 7.65E-01 \\
\hline E1060400601RI & $\mathrm{I}-129$ & $1.10 \mathrm{E}+01$ & & $8.47 \mathrm{E}-01$ & $5.29 \mathrm{E}-01$ \\
\hline E1060400701RI & I-129 & $1.09 \mathrm{E}+00$ & & $2.89 \mathrm{E}-01$ & $5.00 \mathrm{E}-01$ \\
\hline E1060400801RI & $\mathrm{I}-129$ & $3.16 \mathrm{E}-01$ & (U) & $3.08 \mathrm{E}-01$ & $6.41 \mathrm{E}-01$ \\
\hline E1060400901RI & I-129 & $2.31 \mathrm{E}+00$ & & 4.77E-01 & $6.88 \mathrm{E}-01$ \\
\hline E1060400902RI & I-129 & $1.91 \mathrm{E}+00$ & & 4.43E-01 & 7.82E-01 \\
\hline E1060401001RI & I-129 & $6.89 \mathrm{E}-01$ & $(\mathrm{~J})$ & $3.06 \mathrm{E}-01$ & 4.55E-01 \\
\hline E1060401101RI & I-129 & $5.70 \mathrm{E}-01$ & $(\mathrm{~J})$ & $2.79 \mathrm{E}-01$ & $4.68 \mathrm{E}-01$ \\
\hline E1060401201RI & I-129 & $1.31 \mathrm{E}+00$ & & $3.87 \mathrm{E}-01$ & $6.34 \mathrm{E}-01$ \\
\hline E1060401301RI & I-129 & $4.38 \mathrm{E}+00$ & & $6.52 \mathrm{E}-01$ & $9.51 \mathrm{E}-01$ \\
\hline E1060401401RI & I-129 & $-1.69 \mathrm{E}-01$ & $(\mathrm{U})$ & $3.36 \mathrm{E}-01$ & $6.22 \mathrm{E}-01$ \\
\hline E1060401501RI & I-129 & $7.60 \mathrm{E}-01$ & $(\mathrm{~J})$ & $3.50 \mathrm{E}-01$ & $6.24 \mathrm{E}-01$ \\
\hline E1060401601RI & $\mathrm{I}-129$ & $1.73 \mathrm{E}+00$ & & $3.44 \mathrm{E}-01$ & $4.87 \mathrm{E}-01$ \\
\hline E1060401701RI & I-129 & $5.14 \mathrm{E}-01$ & (U) & 2.67E-01 & $5.25 \mathrm{E}-01$ \\
\hline E1060401801RI & $\mathrm{I}-129$ & $9.08 \mathrm{E}-01$ & $(\mathrm{~J})$ & 3.09E-01 & 5.39E-01 \\
\hline E1060401901RI & $\mathrm{I}-129$ & $6.90 \mathrm{E}-01$ & & $1.96 \mathrm{E}-01$ & $5.60 \mathrm{E}-01$ \\
\hline E1060402001RI & $\mathrm{I}-129$ & $3.11 \mathrm{E}+00$ & & 4.94E-01 & $8.55 \mathrm{E}-01$ \\
\hline E1060402101RI & $\mathrm{I}-129$ & $8.13 \mathrm{E}-01$ & $(\mathrm{~J})$ & $3.04 \mathrm{E}-01$ & $6.33 \mathrm{E}-01$ \\
\hline E1060402201RI & $\mathrm{I}-129$ & $1.02 \mathrm{E}+00$ & $(\mathrm{~J})$ & $3.56 \mathrm{E}-01$ & $5.58 \mathrm{E}-01$ \\
\hline E1060402301RI & $\mathrm{I}-129$ & $1.17 \mathrm{E}-01$ & (U) & $3.22 \mathrm{E}-01$ & $6.39 \mathrm{E}-01$ \\
\hline E1060402302RI & $\mathrm{I}-129$ & $1.58 \mathrm{E}-01$ & (U) & $3.29 \mathrm{E}-01$ & $6.58 \mathrm{E}-01$ \\
\hline E1060402401RI & $\mathrm{I}-129$ & $1.27 \mathrm{E}+00$ & & $3.55 \mathrm{E}-01$ & $5.15 \mathrm{E}-01$ \\
\hline E1060402501RI & $\mathrm{I}-129$ & $2.65 \mathrm{E}-01$ & (U) & $2.24 \mathrm{E}-01$ & $5.88 \mathrm{E}-01$ \\
\hline E1060402601RI & $\mathrm{I}-129$ & $2.52 \mathrm{E}-02$ & (U) & $3.77 \mathrm{E}-01$ & $7.20 \mathrm{E}-01$ \\
\hline E1060402701RI & $\mathrm{I}-129$ & $-3.87 \mathrm{E}-01$ & $(\mathrm{U})$ & $4.52 \mathrm{E}-01$ & 7.99E-01 \\
\hline E1060402801RI & $\mathrm{I}-129$ & 4.31E-01 & $(\mathrm{U})$ & $3.19 \mathrm{E}-01$ & 4.61E-01 \\
\hline E1060402901RI & I-129 & 4.22E-01 & $(\mathrm{U})$ & $2.82 \mathrm{E}-01$ & $6.10 \mathrm{E}-01$ \\
\hline E1060403001RI & $\mathrm{I}-129$ & $-2.23 \mathrm{E}-01$ & (U) & 3.33E-01 & $6.03 \mathrm{E}-01$ \\
\hline E1060403101RI & $\mathrm{I}-129$ & $1.32 \mathrm{E}-01$ & $(\mathrm{U})$ & $3.31 \mathrm{E}-01$ & $6.55 \mathrm{E}-01$ \\
\hline E1060403201RI & $\mathrm{I}-129$ & $7.00 \mathrm{E}-01$ & $(\mathrm{~J})$ & $2.88 \mathrm{E}-01$ & $5.72 \mathrm{E}-01$ \\
\hline E1060403301RI & $\mathrm{I}-129$ & $6.16 \mathrm{E}-01$ & $(\mathrm{~J})$ & $3.06 \mathrm{E}-01$ & $5.29 \mathrm{E}-01$ \\
\hline E1060403401RI & I-129 & $9.70 \mathrm{E}+00$ & & $8.72 \mathrm{E}-01$ & $7.52 \mathrm{E}-01$ \\
\hline
\end{tabular}


Table C-2. (continued).

\begin{tabular}{|c|c|c|c|c|c|}
\hline Sample ID & Radionuclide & $\begin{array}{c}\text { Sample Value } \\
(\mathrm{pCi} / \mathrm{g})\end{array}$ & $\begin{array}{l}\text { Validation } \\
\text { Flag }\end{array}$ & $\begin{array}{l}\text { Sample } \\
\text { Uncertainty } \\
(\mathrm{pCi} / \mathrm{g})\end{array}$ & $\begin{array}{l}\mathrm{MDA}^{\mathrm{a}} \\
(\mathrm{pCi} / \mathrm{g})\end{array}$ \\
\hline E1060403501RI & I-129 & 4.00E-01 & $(\mathrm{U})$ & $3.38 \mathrm{E}-01$ & 7.04E-01 \\
\hline E1060403502RI & $\mathrm{I}-129$ & $5.94 \mathrm{E}-01$ & (U) & 3.79E-01 & $7.96 \mathrm{E}-01$ \\
\hline E1060403601RI & $\mathrm{I}-129$ & $9.13 \mathrm{E}-01$ & $(\mathrm{~J})$ & $3.24 \mathrm{E}-01$ & $5.93 \mathrm{E}-01$ \\
\hline E1060403701RI & I-129 & $2.23 \mathrm{E}+00$ & & 3.59E-01 & 5.92E-01 \\
\hline E1060403801RI & $\mathrm{I}-129$ & $8.35 \mathrm{E}-01$ & $(\mathrm{~J})$ & $2.85 \mathrm{E}-01$ & $4.81 \mathrm{E}-01$ \\
\hline E1060403901RI & $\mathrm{I}-129$ & $2.97 \mathrm{E}-01$ & $(\mathrm{U})$ & $2.91 \mathrm{E}-01$ & $6.10 \mathrm{E}-01$ \\
\hline E1060404001RI & I-129 & $1.94 \mathrm{E}+00$ & & $3.36 \mathrm{E}-01$ & 7.59E-01 \\
\hline E1060404101RI & I-129 & $1.98 \mathrm{E}-01$ & $(\mathrm{U})$ & $3.30 \mathrm{E}-01$ & $6.60 \mathrm{E}-01$ \\
\hline E1060404201RI & $\mathrm{I}-129$ & $1.46 \mathrm{E}+00$ & & $4.23 \mathrm{E}-01$ & $5.84 \mathrm{E}-01$ \\
\hline E1060404301RI & I-129 & $5.57 \mathrm{E}-02$ & (U) & $2.87 \mathrm{E}-01$ & $5.66 \mathrm{E}-01$ \\
\hline E1060404401RI & $\mathrm{I}-129$ & $3.14 \mathrm{E}+00$ & & 4.03E-01 & $6.33 \mathrm{E}-01$ \\
\hline E1060404501RI & $\mathrm{I}-129$ & $6.05 \mathrm{E}-01$ & $(\mathrm{~J})$ & $2.94 \mathrm{E}-01$ & $5.24 \mathrm{E}-01$ \\
\hline E1060404601RI & I-129 & $6.89 \mathrm{E}+00$ & & $6.33 \mathrm{E}-01$ & $6.73 \mathrm{E}-01$ \\
\hline E1060404701RI & $\mathrm{I}-129$ & $-1.03 \mathrm{E}-01$ & $(\mathrm{U})$ & $2.80 \mathrm{E}-01$ & $5.26 \mathrm{E}-01$ \\
\hline E1060404801RI & $\mathrm{I}-129$ & $5.52 \mathrm{E}-01$ & (U) & $2.80 \mathrm{E}-01$ & $6.33 \mathrm{E}-01$ \\
\hline E1060404901RI & $\mathrm{I}-129$ & $1.06 \mathrm{E}+00$ & & $3.02 \mathrm{E}-01$ & $5.58 \mathrm{E}-01$ \\
\hline E1060405001RI & $\mathrm{I}-129$ & $2.05 \mathrm{E}-01$ & $(\mathrm{U})$ & $2.46 \mathrm{E}-01$ & $5.20 \mathrm{E}-01$ \\
\hline E1060405101RI & I-129 & $5.89 \mathrm{E}-01$ & $(\mathrm{UJ})$ & 2.79E-01 & $6.35 \mathrm{E}-01$ \\
\hline E1060405201RI & I-129 & $3.93 \mathrm{E}-01$ & (UJ) & $1.67 \mathrm{E}-01$ & $4.84 \mathrm{E}-01$ \\
\hline E1060405301RI & I-129 & $1.77 \mathrm{E}-01$ & $(\mathrm{U})$ & $1.99 \mathrm{E}-01$ & 5.22E-01 \\
\hline E1060405401RI & $\mathrm{I}-129$ & $9.18 \mathrm{E}-01$ & & $2.65 \mathrm{E}-01$ & $4.16 \mathrm{E}-01$ \\
\hline E1060405501RI & $\mathrm{I}-129$ & $2.09 \mathrm{E}+00$ & & 4.15E-01 & $6.79 \mathrm{E}-01$ \\
\hline E1060405601RI & I-129 & 4.89E-01 & $(\mathrm{U})$ & 2.89E-01 & $6.38 \mathrm{E}-01$ \\
\hline E1060405701RI & I-129 & $2.30 \mathrm{E}-01$ & $(\mathrm{U})$ & $2.77 \mathrm{E}-01$ & $5.77 \mathrm{E}-01$ \\
\hline E1060405801RI & $\mathrm{I}-129$ & $2.01 \mathrm{E}+00$ & & 4.24E-01 & $7.77 \mathrm{E}-01$ \\
\hline E1060405901RI & $\mathrm{I}-129$ & $1.41 \mathrm{E}+00$ & & 3.37E-01 & $5.25 \mathrm{E}-01$ \\
\hline E1060406001RI & $\mathrm{I}-129$ & $3.41 \mathrm{E}+00$ & & 4.29E-01 & $6.95 \mathrm{E}-01$ \\
\hline E1060406101RI & I-129 & $5.08 \mathrm{E}+00$ & & $6.23 \mathrm{E}-01$ & $1.01 \mathrm{E}+00$ \\
\hline E1060406201RI & $\mathrm{I}-129$ & $1.72 \mathrm{E}+00$ & & $3.44 \mathrm{E}-01$ & $6.39 \mathrm{E}-01$ \\
\hline E1060406301RI & $\mathrm{I}-129$ & $3.22 \mathrm{E}-01$ & $(\mathrm{U})$ & $3.28 \mathrm{E}-01$ & $6.79 \mathrm{E}-01$ \\
\hline E1060406401RI & $\mathrm{I}-129$ & $6.57 \mathrm{E}+00$ & & 7.91E-01 & $1.12 \mathrm{E}+00$ \\
\hline E1060406501RI & $\mathrm{I}-129$ & 7.72E-01 & & $2.20 \mathrm{E}-01$ & $4.29 \mathrm{E}-01$ \\
\hline E1060406502RI & I-129 & $6.51 \mathrm{E}-01$ & & $1.57 \mathrm{E}-01$ & $5.08 \mathrm{E}-01$ \\
\hline \multicolumn{6}{|c|}{$\begin{array}{l}\mathrm{J}=\text { analysis performed and radioactivity detected. Concentrations are less than the decision level and greater than the } \\
\text { minimum detectable concentration associated with the sample results. } \\
\mathrm{U}=\text { nondetect. } \\
\mathrm{UJ}=\text { false positive due to concentrations less than the decision level and the minimum detectable concentration associated } \\
\text { with the sample result. }\end{array}$} \\
\hline
\end{tabular}


Table C-3. ESP-116-04 confirmatory sample results for radiological analytes from Pond 1 on CPP-67.

\begin{tabular}{|c|c|c|c|c|c|}
\hline Sample ID & Radionuclide & $\begin{array}{l}\text { Sample Value } \\
(\mathrm{pCi} / \mathrm{g})\end{array}$ & $\begin{array}{c}\text { Validation } \\
\text { Flag }\end{array}$ & $\begin{array}{c}\text { Sample } \\
\text { Uncertainty } \\
(\mathrm{pCi} / \mathrm{g})\end{array}$ & $\begin{array}{l}\mathrm{MDA}^{\mathrm{a}} \\
(\mathrm{pCi} / \mathrm{g})\end{array}$ \\
\hline E1160400001R4 & Ag-108M & $5.11 \mathrm{E}-03$ & (U) & $1.17 \mathrm{E}-02$ & 4.32E-02 \\
\hline E1160400001R4 & Ag-110M & $4.12 \mathrm{E}-02$ & (UJ) & $1.55 \mathrm{E}-02$ & $5.56 \mathrm{E}-02$ \\
\hline E1160400001R4 & Ce-144 & $-7.02 \mathrm{E}-02$ & $(\mathrm{U})$ & $8.80 \mathrm{E}-02$ & $2.80 \mathrm{E}-01$ \\
\hline E1160400001R4 & Co-60 & $-3.29 \mathrm{E}-03$ & (U) & $1.63 \mathrm{E}-02$ & 5.94E-02 \\
\hline E1160400001R4 & Cs-134 & $5.47 \mathrm{E}-02$ & $(\mathrm{UJ})$ & $2.06 \mathrm{E}-02$ & $5.93 \mathrm{E}-02$ \\
\hline E1160400001R4 & Cs-137 & $4.07 \mathrm{E}-01$ & & 3.79E-02 & $5.23 \mathrm{E}-02$ \\
\hline E1160400001R4 & Eu-152 & $1.69 \mathrm{E}-03$ & (U) & $3.63 \mathrm{E}-02$ & $1.34 \mathrm{E}-01$ \\
\hline E1160400001R4 & Eu-154 & $-1.95 \mathrm{E}-02$ & $(\mathrm{U})$ & $5.14 \mathrm{E}-02$ & $1.85 \mathrm{E}-01$ \\
\hline E1160400001R4 & Eu-155 & $5.37 \mathrm{E}-02$ & (U) & $3.94 \mathrm{E}-02$ & $1.50 \mathrm{E}-01$ \\
\hline E1160400001R4 & $\mathrm{Mn}-54$ & $2.77 \mathrm{E}-02$ & (U) & $1.44 \mathrm{E}-02$ & $5.59 \mathrm{E}-02$ \\
\hline E1160400001R4 & Ru-106 & 7.73E-02 & $(\mathrm{U})$ & $1.26 \mathrm{E}-01$ & $4.76 \mathrm{E}-01$ \\
\hline E1160400001R4 & $\mathrm{Sb}-125$ & $-6.26 \mathrm{E}-03$ & (U) & $3.25 \mathrm{E}-02$ & $1.17 \mathrm{E}-01$ \\
\hline E1160400001R4 & $\mathrm{Zn}-65$ & $1.06 \mathrm{E}-01$ & $(\mathrm{UJ})$ & 4.40E-02 & $1.51 \mathrm{E}-01$ \\
\hline E1160400101R4 & Ag-108M & $-1.25 \mathrm{E}-02$ & $(\mathrm{U})$ & $1.41 \mathrm{E}-02$ & $5.24 \mathrm{E}-02$ \\
\hline E1160400101R4 & Ag-110M & $-5.64 \mathrm{E}-03$ & $(\mathrm{U})$ & $1.68 \mathrm{E}-02$ & $5.30 \mathrm{E}-02$ \\
\hline E1160400101R4 & $\mathrm{Ce}-144$ & $3.80 \mathrm{E}-02$ & $(\mathrm{U})$ & $7.67 \mathrm{E}-02$ & $2.99 \mathrm{E}-01$ \\
\hline E1160400101R4 & Co-60 & $2.02 \mathrm{E}-02$ & (U) & $1.75 \mathrm{E}-02$ & $6.30 \mathrm{E}-02$ \\
\hline E1160400101R4 & Cs-134 & $4.86 \mathrm{E}-02$ & (UJ) & $1.83 \mathrm{E}-02$ & $6.73 \mathrm{E}-02$ \\
\hline E1160400101R4 & Cs-137 & $1.15 \mathrm{E}+00$ & & 7.74E-02 & $5.74 \mathrm{E}-02$ \\
\hline E1160400101R4 & Eu-152 & $3.90 \mathrm{E}-02$ & $(\mathrm{U})$ & 4.59E-02 & $1.51 \mathrm{E}-01$ \\
\hline E1160400101R4 & Eu-154 & $3.79 \mathrm{E}-03$ & (U) & 4.61E-02 & $1.73 \mathrm{E}-01$ \\
\hline E1160400101R4 & Eu-155 & 7.59E-02 & (U) & $4.83 \mathrm{E}-02$ & $1.37 \mathrm{E}-01$ \\
\hline E1160400101R4 & Mn-54 & $2.36 \mathrm{E}-02$ & $(\mathrm{U})$ & $1.49 \mathrm{E}-02$ & $5.78 \mathrm{E}-02$ \\
\hline E1160400101R4 & Ru-106 & $-5.67 \mathrm{E}-02$ & (U) & $1.30 \mathrm{E}-01$ & $4.76 \mathrm{E}-01$ \\
\hline E1160400101R4 & $\mathrm{Sb}-125$ & $1.54 \mathrm{E}-02$ & $(\mathrm{U})$ & $4.09 \mathrm{E}-02$ & $1.49 \mathrm{E}-01$ \\
\hline E1160400101R4 & $\mathrm{Zn}-65$ & $-6.97 \mathrm{E}-02$ & (U) & $3.62 \mathrm{E}-02$ & $1.24 \mathrm{E}-01$ \\
\hline E1160400201R4 & Ag-108M & $-5.44 \mathrm{E}-03$ & $(\mathrm{U})$ & $9.98 \mathrm{E}-03$ & $3.75 \mathrm{E}-02$ \\
\hline E1160400201R4 & Ag-110M & $1.12 \mathrm{E}-02$ & (U) & $1.15 \mathrm{E}-02$ & $3.92 \mathrm{E}-02$ \\
\hline E1160400201R4 & Ce-144 & $9.18 \mathrm{E}-02$ & $(\mathrm{U})$ & 7.43E-02 & $2.56 \mathrm{E}-01$ \\
\hline E1160400201R4 & Co-60 & $1.73 \mathrm{E}-02$ & (U) & $1.27 \mathrm{E}-02$ & $5.02 \mathrm{E}-02$ \\
\hline E1160400201R4 & Cs-134 & $5.66 \mathrm{E}-02$ & (UJ) & $1.37 \mathrm{E}-02$ & $5.30 \mathrm{E}-02$ \\
\hline E1160400201R4 & Cs-137 & $8.30 \mathrm{E}-01$ & & 4.92E-02 & $4.34 \mathrm{E}-02$ \\
\hline E1160400201R4 & Eu-152 & $-2.28 \mathrm{E}-02$ & $(\mathrm{U})$ & $2.80 \mathrm{E}-02$ & $1.07 \mathrm{E}-01$ \\
\hline E1160400201R4 & Eu-154 & $3.79 \mathrm{E}-02$ & (U) & $2.60 \mathrm{E}-02$ & $1.30 \mathrm{E}-01$ \\
\hline E1160400201R4 & Eu-155 & $1.40 \mathrm{E}-02$ & $(\mathrm{U})$ & $3.54 \mathrm{E}-02$ & $1.40 \mathrm{E}-01$ \\
\hline E1160400201R4 & $\mathrm{Mn}-54$ & $3.37 \mathrm{E}-02$ & $(\mathrm{UJ})$ & $1.19 \mathrm{E}-02$ & $3.87 \mathrm{E}-02$ \\
\hline E1160400201R4 & Ru-106 & $-2.36 \mathrm{E}-02$ & (U) & $9.71 \mathrm{E}-02$ & $3.57 \mathrm{E}-01$ \\
\hline E1160400201R4 & Sb-125 & $-2.59 \mathrm{E}-02$ & $(\mathrm{U})$ & $2.85 \mathrm{E}-02$ & $1.06 \mathrm{E}-01$ \\
\hline E1160400201R4 & $\mathrm{Zn}-65$ & $-3.92 \mathrm{E}-02$ & (U) & $3.09 \mathrm{E}-02$ & $9.15 \mathrm{E}-02$ \\
\hline
\end{tabular}


Table C-3. (continued).

\begin{tabular}{|c|c|c|c|c|c|}
\hline Sample ID & Radionuclide & $\begin{array}{c}\text { Sample Value } \\
(\mathrm{pCi} / \mathrm{g})\end{array}$ & $\begin{array}{c}\text { Validation } \\
\text { Flag }\end{array}$ & $\begin{array}{c}\text { Sample } \\
\text { Uncertainty } \\
(\mathrm{pCi} / \mathrm{g})\end{array}$ & $\begin{array}{l}\mathrm{MDA}^{\mathrm{a}} \\
(\mathrm{pCi} / \mathrm{g})\end{array}$ \\
\hline E1160400301R4 & Ag-108M & $-2.35 \mathrm{E}-03$ & $(\mathrm{U})$ & $8.30 \mathrm{E}-03$ & $3.18 \mathrm{E}-02$ \\
\hline E1160400301R4 & Ag-110M & $-9.13 \mathrm{E}-03$ & (U) & $1.13 \mathrm{E}-02$ & $3.49 \mathrm{E}-02$ \\
\hline E1160400301R4 & $\mathrm{Ce}-144$ & $-7.52 \mathrm{E}-03$ & $(\mathrm{U})$ & $5.73 \mathrm{E}-02$ & $2.26 \mathrm{E}-01$ \\
\hline E1160400301R4 & $\mathrm{Co}-60$ & $-1.21 \mathrm{E}-03$ & (U) & $1.20 \mathrm{E}-02$ & $3.84 \mathrm{E}-02$ \\
\hline E1160400301R4 & Cs-134 & $4.63 \mathrm{E}-02$ & $(\mathrm{~J})$ & $1.33 \mathrm{E}-02$ & $5.43 \mathrm{E}-02$ \\
\hline E1160400301R4 & Cs-137 & $2.89 \mathrm{E}-01$ & & $2.87 \mathrm{E}-02$ & $3.79 \mathrm{E}-02$ \\
\hline E1160400301R4 & Eu-152 & $4.58 \mathrm{E}-02$ & (U) & $2.97 \mathrm{E}-02$ & $1.13 \mathrm{E}-01$ \\
\hline E1160400301R4 & Eu-154 & $3.22 \mathrm{E}-02$ & (U) & $4.33 \mathrm{E}-02$ & $1.45 \mathrm{E}-01$ \\
\hline E1160400301R4 & Eu-155 & $4.68 \mathrm{E}-02$ & $(\mathrm{U})$ & $2.93 \mathrm{E}-02$ & $1.21 \mathrm{E}-01$ \\
\hline E1160400301R4 & $\mathrm{Mn}-54$ & $1.28 \mathrm{E}-02$ & $(\mathrm{U})$ & $1.21 \mathrm{E}-02$ & $3.60 \mathrm{E}-02$ \\
\hline E1160400301R4 & Ru-106 & $-9.91 \mathrm{E}-03$ & (U) & $8.49 \mathrm{E}-02$ & $3.17 \mathrm{E}-01$ \\
\hline E1160400301R4 & $\mathrm{Sb}-125$ & $-2.26 \mathrm{E}-02$ & (U) & $2.57 \mathrm{E}-02$ & $9.60 \mathrm{E}-02$ \\
\hline E1160400301R4 & $\mathrm{Zn}-65$ & $-5.69 \mathrm{E}-02$ & $(\mathrm{U})$ & $3.29 \mathrm{E}-02$ & $9.31 \mathrm{E}-02$ \\
\hline E1160400401R4 & Ag-108M & $-8.60 \mathrm{E}-03$ & $(\mathrm{U})$ & $1.65 \mathrm{E}-02$ & $5.86 \mathrm{E}-02$ \\
\hline E1160400401R4 & Ag-110M & $1.62 \mathrm{E}-01$ & (UJ) & 2.09E-02 & 7.95E-02 \\
\hline E1160400401R4 & $\mathrm{Ce}-144$ & $3.22 \mathrm{E}-02$ & $(\mathrm{U})$ & $7.36 \mathrm{E}-02$ & $2.77 \mathrm{E}-01$ \\
\hline E1160400401R4 & Co-60 & $2.52 \mathrm{E}-02$ & (U) & $1.54 \mathrm{E}-02$ & $6.12 \mathrm{E}-02$ \\
\hline E1160400401R4 & Cs-134 & $1.05 \mathrm{E}-01$ & (UJ) & $2.10 \mathrm{E}-02$ & $5.47 \mathrm{E}-02$ \\
\hline E1160400401R4 & Cs-137 & $5.21 \mathrm{E}+00$ & & $2.55 \mathrm{E}-01$ & $5.18 \mathrm{E}-02$ \\
\hline E1160400401R4 & Eu-152 & $6.38 \mathrm{E}-02$ & $(\mathrm{U})$ & 4.14E-02 & $1.58 \mathrm{E}-01$ \\
\hline E1160400401R4 & Eu-154 & $1.68 \mathrm{E}-02$ & $(\mathrm{U})$ & $4.11 \mathrm{E}-02$ & $1.55 \mathrm{E}-01$ \\
\hline E1160400401R4 & Eu-155 & $4.15 \mathrm{E}-02$ & (U) & $3.65 \mathrm{E}-02$ & $1.27 \mathrm{E}-01$ \\
\hline E1160400401R4 & $\mathrm{Mn}-54$ & $3.25 \mathrm{E}-02$ & $(\mathrm{U})$ & $2.51 \mathrm{E}-02$ & $5.09 \mathrm{E}-02$ \\
\hline E1160400401R4 & Ru-106 & $1.13 \mathrm{E}-01$ & $(\mathrm{U})$ & $9.30 \mathrm{E}-02$ & $4.21 \mathrm{E}-01$ \\
\hline E1160400401R4 & $\mathrm{Sb}-125$ & $4.21 \mathrm{E}-02$ & $(\mathrm{U})$ & $4.58 \mathrm{E}-02$ & $1.69 \mathrm{E}-01$ \\
\hline E1160400401R4 & $\mathrm{Zn}-65$ & $-2.49 \mathrm{E}-02$ & $(\mathrm{U})$ & $3.76 \mathrm{E}-02$ & $1.15 \mathrm{E}-01$ \\
\hline E1160400501R4 & Ag-108M & $3.80 \mathrm{E}-03$ & $(\mathrm{U})$ & $1.28 \mathrm{E}-02$ & 4.77E-02 \\
\hline E1160400501R4 & Ag-110M & $1.15 \mathrm{E}-02$ & (U) & $1.37 \mathrm{E}-02$ & $4.71 \mathrm{E}-02$ \\
\hline E1160400501R4 & $\mathrm{Ce}-144$ & $-7.67 \mathrm{E}-02$ & $(\mathrm{U})$ & $8.65 \mathrm{E}-02$ & $3.18 \mathrm{E}-01$ \\
\hline E1160400501R4 & Co-60 & $7.23 \mathrm{E}-03$ & (U) & $1.46 \mathrm{E}-02$ & $5.58 \mathrm{E}-02$ \\
\hline E1160400501R4 & Cs-134 & $8.28 \mathrm{E}-02$ & (UJ) & $3.07 \mathrm{E}-02$ & $6.68 \mathrm{E}-02$ \\
\hline E1160400501R4 & Cs-137 & $3.37 \mathrm{E}-02$ & $(\mathrm{UJ})$ & $1.48 \mathrm{E}-02$ & $5.76 \mathrm{E}-02$ \\
\hline E1160400501R4 & $\mathrm{Eu}-152$ & 4.62E-02 & $(\mathrm{U})$ & $3.90 \mathrm{E}-02$ & $1.51 \mathrm{E}-01$ \\
\hline E1160400501R4 & Eu-154 & $3.24 \mathrm{E}-02$ & $(\mathrm{U})$ & $4.49 \mathrm{E}-02$ & $1.72 \mathrm{E}-01$ \\
\hline E1160400501R4 & Eu-155 & $7.58 \mathrm{E}-02$ & $(\mathrm{U})$ & $4.53 \mathrm{E}-02$ & $1.78 \mathrm{E}-01$ \\
\hline E1160400501R4 & Mn-54 & $-2.19 \mathrm{E}-03$ & (U) & $1.44 \mathrm{E}-02$ & $5.26 \mathrm{E}-02$ \\
\hline E1160400501R4 & Ru-106 & $-2.19 \mathrm{E}-01$ & $(\mathrm{U})$ & $1.19 \mathrm{E}-01$ & $4.21 \mathrm{E}-01$ \\
\hline E1160400501R4 & $\mathrm{Sb}-125$ & $-3.72 \mathrm{E}-02$ & $(\mathrm{U})$ & $3.70 \mathrm{E}-02$ & $1.32 \mathrm{E}-01$ \\
\hline E1160400501R4 & $\mathrm{Zn}-65$ & $4.68 \mathrm{E}-04$ & $(\mathrm{U})$ & $4.04 \mathrm{E}-02$ & $1.24 \mathrm{E}-01$ \\
\hline E1160400601R4 & Ag-108M & $5.11 \mathrm{E}-03$ & (U) & $1.19 \mathrm{E}-02$ & $4.40 \mathrm{E}-02$ \\
\hline
\end{tabular}


Table C-3. (continued).

\begin{tabular}{|c|c|c|c|c|c|}
\hline Sample ID & Radionuclide & $\begin{array}{c}\text { Sample Value } \\
(\mathrm{pCi} / \mathrm{g})\end{array}$ & $\begin{array}{c}\text { Validation } \\
\text { Flag }\end{array}$ & $\begin{array}{c}\text { Sample } \\
\text { Uncertainty } \\
(\mathrm{pCi} / \mathrm{g})\end{array}$ & $\begin{array}{l}\mathrm{MDA}^{\mathrm{a}} \\
(\mathrm{pCi} / \mathrm{g})\end{array}$ \\
\hline E1160400601R4 & Ag-110M & $1.88 \mathrm{E}-03$ & (U) & $1.20 \mathrm{E}-02$ & $4.50 \mathrm{E}-02$ \\
\hline E1160400601R4 & $\mathrm{Ce}-144$ & $-1.99 \mathrm{E}-01$ & (U) & $7.51 \mathrm{E}-02$ & $2.57 \mathrm{E}-01$ \\
\hline E1160400601R4 & Co-60 & $1.52 \mathrm{E}-02$ & $(\mathrm{U})$ & $1.37 \mathrm{E}-02$ & $5.41 \mathrm{E}-02$ \\
\hline E1160400601R4 & Cs-134 & $6.71 \mathrm{E}-02$ & (UJ) & $1.81 \mathrm{E}-02$ & 5.89E-02 \\
\hline E1160400601R4 & Cs-137 & $2.40 \mathrm{E}-03$ & $(\mathrm{U})$ & $1.25 \mathrm{E}-02$ & 4.72E-02 \\
\hline E1160400601R4 & Eu-152 & $-1.31 \mathrm{E}-02$ & $(\mathrm{U})$ & $3.40 \mathrm{E}-02$ & $1.25 \mathrm{E}-01$ \\
\hline E1160400601R4 & Eu-154 & $6.57 \mathrm{E}-03$ & (U) & $4.40 \mathrm{E}-02$ & $1.64 \mathrm{E}-01$ \\
\hline E1160400601R4 & Eu-155 & $2.25 \mathrm{E}-02$ & $(\mathrm{U})$ & $3.77 \mathrm{E}-02$ & $1.44 \mathrm{E}-01$ \\
\hline E1160400601R4 & $\mathrm{Mn}-54$ & $1.93 \mathrm{E}-02$ & $(\mathrm{U})$ & $1.29 \mathrm{E}-02$ & $5.25 \mathrm{E}-02$ \\
\hline E1160400601R4 & Ru-106 & $-6.09 \mathrm{E}-02$ & $(\mathrm{U})$ & $1.05 \mathrm{E}-01$ & 3.87E-01 \\
\hline E1160400601R4 & $\mathrm{Sb}-125$ & $1.70 \mathrm{E}-02$ & $(\mathrm{U})$ & $3.20 \mathrm{E}-02$ & 1.19E-01 \\
\hline E1160400601R4 & Zn-65 & $5.77 \mathrm{E}-02$ & (U) & $4.18 \mathrm{E}-02$ & $1.37 \mathrm{E}-01$ \\
\hline E1160400701R4 & Ag-108M & $-2.44 \mathrm{E}-02$ & $(\mathrm{U})$ & $1.52 \mathrm{E}-02$ & $5.53 \mathrm{E}-02$ \\
\hline E1160400701R4 & Ag-110M & $1.30 \mathrm{E}-01$ & $(\mathrm{UJ})$ & $1.82 \mathrm{E}-02$ & $7.32 \mathrm{E}-02$ \\
\hline E1160400701R4 & $\mathrm{Ce}-144$ & $7.89 \mathrm{E}-02$ & $(\mathrm{U})$ & $8.26 \mathrm{E}-02$ & $3.27 \mathrm{E}-01$ \\
\hline E1160400701R4 & $\mathrm{Co}-60$ & $1.11 \mathrm{E}-01$ & & $2.10 \mathrm{E}-02$ & $5.42 \mathrm{E}-02$ \\
\hline E1160400701R4 & Cs-134 & $1.18 \mathrm{E}-01$ & (UJ) & $2.14 \mathrm{E}-02$ & 6.39E-02 \\
\hline E1160400701R4 & Cs-137 & $5.00 \mathrm{E}+00$ & & $7.86 \mathrm{E}-02$ & $5.10 \mathrm{E}-02$ \\
\hline E1160400701R4 & Eu-152 & $8.00 \mathrm{E}-02$ & (U) & $4.18 \mathrm{E}-02$ & $1.61 \mathrm{E}-01$ \\
\hline E1160400701R4 & $\mathrm{Eu}-154$ & $-1.10 \mathrm{E}-02$ & $(\mathrm{U})$ & $4.21 \mathrm{E}-02$ & $1.54 \mathrm{E}-01$ \\
\hline E1160400701R4 & Eu-155 & $4.17 \mathrm{E}-03$ & (U) & 4.19E-02 & $1.67 \mathrm{E}-01$ \\
\hline E1160400701R4 & Mn-54 & $9.53 \mathrm{E}-03$ & (U) & $1.24 \mathrm{E}-02$ & $4.68 \mathrm{E}-02$ \\
\hline E1160400701R4 & $\mathrm{Ru}-106$ & $-1.25 \mathrm{E}-01$ & $(\mathrm{U})$ & $1.16 \mathrm{E}-01$ & 4.15E-01 \\
\hline E1160400701R4 & $\mathrm{Sb}-125$ & $1.64 \mathrm{E}-02$ & $(\mathrm{U})$ & 4.64E-02 & $1.65 \mathrm{E}-01$ \\
\hline E1160400701R4 & $\mathrm{Zn}-65$ & $1.74 \mathrm{E}-02$ & $(\mathrm{U})$ & $3.57 \mathrm{E}-02$ & 1.19E-01 \\
\hline E1160400001RI & $\mathrm{I}-129$ & $1.94 \mathrm{E}-01$ & $(\mathrm{U})$ & $1.71 \mathrm{E}-01$ & 4.62E-01 \\
\hline E1160400101RI & $\mathrm{I}-129$ & $4.83 \mathrm{E}-01$ & $(\mathrm{U})$ & $3.29 \mathrm{E}-01$ & 4.91E-01 \\
\hline E1160400201RI & I-129 & 4.32E-01 & (UJ) & $2.13 \mathrm{E}-01$ & 4.29E-01 \\
\hline E1160400301RI & I-129 & $-9.00 \mathrm{E}-03$ & $(\mathrm{U})$ & $1.54 \mathrm{E}-01$ & $3.89 \mathrm{E}-01$ \\
\hline E1160400401RI & I-129 & $-2.97 \mathrm{E}-01$ & (U) & $2.55 \mathrm{E}-01$ & $5.79 \mathrm{E}-01$ \\
\hline E1160400501RI & $\mathrm{I}-129$ & $-7.91 \mathrm{E}-02$ & $(\mathrm{U})$ & $1.91 \mathrm{E}-01$ & 4.60E- 01 \\
\hline E1160400601RI & $\mathrm{I}-129$ & 4.16E-01 & $(\mathrm{UJ})$ & $1.74 \mathrm{E}-01$ & $5.77 \mathrm{E}-01$ \\
\hline E1160400701RI & I-129 & $1.02 \mathrm{E}+00$ & $(\mathrm{UJ})$ & $3.06 \mathrm{E}-01$ & $5.30 \mathrm{E}-01$ \\
\hline \multicolumn{6}{|c|}{$\begin{array}{l}J=\text { analysis performed and radioactivity detected. Concentrations are less than the decision level and greater than the } \\
\text { minimum detectable concentration associated with the sample results. } \\
U=\text { nondetect. } \\
U J=\text { false positive due to concentrations less than the decision level and the minimum detectable concentration associated } \\
\text { with the sample result. } \\
\text { a. MDA = minimum detectable activity. }\end{array}$} \\
\hline
\end{tabular}


Table C-4. ESP-116-04 confirmatory sample results for radiological analytes from Pond 2 on CPP-67.

\begin{tabular}{|c|c|c|c|c|c|}
\hline Sample ID & Radionuclide & $\begin{array}{l}\text { Sample Value } \\
\text { (pCi } / \mathrm{g})\end{array}$ & $\begin{array}{c}\text { Validation } \\
\text { Flag }\end{array}$ & $\begin{array}{c}\text { Sample } \\
\text { Uncertainty } \\
(\mathrm{pCi} / \mathrm{g})\end{array}$ & $\begin{array}{l}\mathrm{MDA}^{\mathrm{a}} \\
(\mathrm{pCi} / \mathrm{g})\end{array}$ \\
\hline E1160400801R4 & Ag-108M & $-5.90 \mathrm{E}-03$ & $(\mathrm{U})$ & $1.31 \mathrm{E}-02$ & $4.92 \mathrm{E}-02$ \\
\hline E1160400801R4 & Ag-110M & $-3.14 \mathrm{E}-03$ & (U) & $1.63 \mathrm{E}-02$ & $5.21 \mathrm{E}-02$ \\
\hline E1160400801R4 & $\mathrm{Ce}-144$ & $-7.85 \mathrm{E}-02$ & $(\mathrm{U})$ & $8.78 \mathrm{E}-02$ & $2.91 \mathrm{E}-01$ \\
\hline E1160400801R4 & Co-60 & $3.61 \mathrm{E}-03$ & (U) & $1.67 \mathrm{E}-02$ & $6.27 \mathrm{E}-02$ \\
\hline E1160400801R4 & Cs-134 & 4.07E-02 & (UJ) & $1.69 \mathrm{E}-02$ & $6.73 \mathrm{E}-02$ \\
\hline E1160400801R4 & Cs-137 & $8.26 \mathrm{E}-01$ & & $6.24 \mathrm{E}-02$ & $5.47 \mathrm{E}-02$ \\
\hline E1160400801R4 & Eu-152 & $-4.14 \mathrm{E}-02$ & (U) & $3.89 \mathrm{E}-02$ & $1.38 \mathrm{E}-01$ \\
\hline E1160400801R4 & Eu-154 & $2.47 \mathrm{E}-02$ & (U) & 4.77E-02 & $1.82 \mathrm{E}-01$ \\
\hline E1160400801R4 & Eu-155 & $7.66 \mathrm{E}-02$ & (U) & $3.99 \mathrm{E}-02$ & $1.37 \mathrm{E}-01$ \\
\hline E1160400801R4 & Mn-54 & $2.98 \mathrm{E}-02$ & $(\mathrm{U})$ & $1.54 \mathrm{E}-02$ & $6.03 \mathrm{E}-02$ \\
\hline E1160400801R4 & $\mathrm{Ru}-106$ & $-2.48 \mathrm{E}-01$ & $(\mathrm{U})$ & $1.36 \mathrm{E}-01$ & 4.69E-01 \\
\hline E1160400801R4 & Sb-125 & $-2.92 \mathrm{E}-02$ & (U) & $4.12 \mathrm{E}-02$ & $1.45 \mathrm{E}-01$ \\
\hline E1160400801R4 & $\mathrm{Zn}-65$ & $-5.33 \mathrm{E}-02$ & $(\mathrm{U})$ & $4.45 \mathrm{E}-02$ & $1.33 \mathrm{E}-01$ \\
\hline E1160400901R4 & Ag-108M & $2.01 \mathrm{E}-02$ & $(\mathrm{U})$ & $1.10 \mathrm{E}-02$ & $4.21 \mathrm{E}-02$ \\
\hline E1160400901R4 & Ag-110M & $-1.21 \mathrm{E}-03$ & (U) & $1.48 \mathrm{E}-02$ & $4.72 \mathrm{E}-02$ \\
\hline E1160400901R4 & Ce-144 & $-1.36 \mathrm{E}-01$ & $(\mathrm{U})$ & $6.77 \mathrm{E}-02$ & $2.50 \mathrm{E}-01$ \\
\hline E1160400901R4 & Co-60 & $4.05 \mathrm{E}-03$ & (U) & $1.31 \mathrm{E}-02$ & $4.93 \mathrm{E}-02$ \\
\hline E1160400901R4 & Cs-134 & $1.87 \mathrm{E}-02$ & (U) & $1.64 \mathrm{E}-02$ & $5.54 \mathrm{E}-02$ \\
\hline E1160400901R4 & Cs-137 & $1.33 \mathrm{E}-01$ & & $2.15 \mathrm{E}-02$ & $4.80 \mathrm{E}-02$ \\
\hline E1160400901R4 & Eu-152 & $-4.34 \mathrm{E}-02$ & (U) & $3.32 \mathrm{E}-02$ & $1.23 \mathrm{E}-01$ \\
\hline E1160400901R4 & Eu-154 & $-2.97 \mathrm{E}-02$ & (U) & $4.54 \mathrm{E}-02$ & $1.60 \mathrm{E}-01$ \\
\hline E1160400901R4 & $\mathrm{Eu}-155$ & $4.06 \mathrm{E}-02$ & (U) & $3.48 \mathrm{E}-02$ & $1.40 \mathrm{E}-01$ \\
\hline E1160400901R4 & Mn-54 & $-1.27 \mathrm{E}-02$ & (U) & $1.29 \mathrm{E}-02$ & 4.70E-02 \\
\hline E1160400901R4 & $\mathrm{Ru}-106$ & $5.63 \mathrm{E}-02$ & (U) & $1.01 \mathrm{E}-01$ & 3.84E-01 \\
\hline E1160400901R4 & Sb-125 & $-9.11 \mathrm{E}-03$ & $(\mathrm{U})$ & $3.14 \mathrm{E}-02$ & $1.18 \mathrm{E}-01$ \\
\hline E1160400901R4 & $\mathrm{Zn}-65$ & $2.28 \mathrm{E}-02$ & (U) & $3.69 \mathrm{E}-02$ & $1.22 \mathrm{E}-01$ \\
\hline E1160401001R4 & Ag-108M & $-9.05 E-03$ & (U) & $1.02 \mathrm{E}-02$ & $3.77 \mathrm{E}-02$ \\
\hline E1160401001R4 & Ag-110M & $-8.97 \mathrm{E}-03$ & $(\mathrm{U})$ & $1.18 \mathrm{E}-02$ & $3.62 \mathrm{E}-02$ \\
\hline E1160401001R4 & $\mathrm{Ce}-144$ & $2.76 \mathrm{E}-03$ & (U) & $6.65 \mathrm{E}-02$ & $2.54 \mathrm{E}-01$ \\
\hline E1160401001R4 & Co-60 & $-1.01 \mathrm{E}-03$ & $(\mathrm{U})$ & 1.19E-02 & $4.42 \mathrm{E}-02$ \\
\hline E1160401001R4 & Cs-134 & $8.30 \mathrm{E}-02$ & (UJ) & $2.61 \mathrm{E}-02$ & $6.15 \mathrm{E}-02$ \\
\hline E1160401001R4 & Cs-137 & $1.99 \mathrm{E}-01$ & & $3.01 \mathrm{E}-02$ & $3.88 \mathrm{E}-02$ \\
\hline E1160401001R4 & Eu-152 & $-3.34 \mathrm{E}-02$ & (U) & $2.83 \mathrm{E}-02$ & $1.05 \mathrm{E}-01$ \\
\hline E1160401001R4 & Eu-154 & $-2.73 \mathrm{E}-02$ & $(\mathrm{U})$ & $4.06 \mathrm{E}-02$ & $1.44 \mathrm{E}-01$ \\
\hline E1160401001R4 & Eu-155 & $9.53 \mathrm{E}-02$ & (UJ) & $4.58 \mathrm{E}-02$ & $1.35 \mathrm{E}-01$ \\
\hline E1160401001R4 & $\mathrm{Mn}-54$ & $-1.69 \mathrm{E}-02$ & $(\mathrm{U})$ & $1.34 \mathrm{E}-02$ & $4.51 \mathrm{E}-02$ \\
\hline E1160401001R4 & Ru-106 & $-4.67 \mathrm{E}-02$ & $(\mathrm{U})$ & $9.40 \mathrm{E}-02$ & $3.41 \mathrm{E}-01$ \\
\hline E1160401001R4 & Sb-125 & $-2.13 \mathrm{E}-02$ & $(\mathrm{U})$ & $2.81 \mathrm{E}-02$ & $1.04 \mathrm{E}-01$ \\
\hline E1160401001R4 & $\mathrm{Zn}-65$ & $1.47 \mathrm{E}-02$ & (U) & $3.24 \mathrm{E}-02$ & $1.07 \mathrm{E}-01$ \\
\hline
\end{tabular}


Table C-4. (continued).

\begin{tabular}{|c|c|c|c|c|c|}
\hline Sample ID & Radionuclide & $\begin{array}{c}\text { Sample Value } \\
(\mathrm{pCi} / \mathrm{g})\end{array}$ & $\begin{array}{c}\text { Validation } \\
\text { Flag }\end{array}$ & $\begin{array}{c}\text { Sample } \\
\text { Uncertainty } \\
(\mathrm{pCi} / \mathrm{g})\end{array}$ & $\begin{array}{l}\mathrm{MDA}^{\mathrm{a}} \\
(\mathrm{pCi} / \mathrm{g})\end{array}$ \\
\hline E1160401101R4 & Ag-108M & $2.08 \mathrm{E}-02$ & $(\mathrm{UJ})$ & $8.71 \mathrm{E}-03$ & $3.63 \mathrm{E}-02$ \\
\hline E1160401101R4 & Ag-110M & $1.47 \mathrm{E}-02$ & (U) & $1.13 \mathrm{E}-02$ & $3.95 \mathrm{E}-02$ \\
\hline E1160401101R4 & $\mathrm{Ce}-144$ & $7.61 \mathrm{E}-03$ & $(\mathrm{U})$ & $5.42 \mathrm{E}-02$ & $2.12 \mathrm{E}-01$ \\
\hline E1160401101R4 & $\mathrm{Co}-60$ & $5.29 \mathrm{E}-03$ & (U) & $1.34 \mathrm{E}-02$ & $5.03 \mathrm{E}-02$ \\
\hline E1160401101R4 & Cs-134 & $1.78 \mathrm{E}-02$ & (U) & $1.29 \mathrm{E}-02$ & 4.94E-02 \\
\hline E1160401101R4 & Cs-137 & $7.55 \mathrm{E}-02$ & $(\mathrm{~J})$ & $3.11 \mathrm{E}-02$ & 4.34E-02 \\
\hline E1160401101R4 & Eu-152 & $-9.79 \mathrm{E}-03$ & (U) & $2.87 \mathrm{E}-02$ & $1.02 \mathrm{E}-01$ \\
\hline E1160401101R4 & Eu-154 & $-2.36 \mathrm{E}-02$ & (U) & $3.86 \mathrm{E}-02$ & $1.37 \mathrm{E}-01$ \\
\hline E1160401101R4 & $\mathrm{Eu}-155$ & $9.62 \mathrm{E}-03$ & $(\mathrm{U})$ & $2.82 \mathrm{E}-02$ & $1.12 \mathrm{E}-01$ \\
\hline E1160401101R4 & Mn-54 & $1.01 \mathrm{E}-02$ & $(\mathrm{U})$ & $1.21 \mathrm{E}-02$ & $4.51 \mathrm{E}-02$ \\
\hline E1160401101R4 & $\mathrm{Ru}-106$ & $-7.27 \mathrm{E}-03$ & $(\mathrm{U})$ & $9.41 \mathrm{E}-02$ & $3.48 \mathrm{E}-01$ \\
\hline E1160401101R4 & Sb-125 & $-4.84 \mathrm{E}-02$ & (U) & $2.75 \mathrm{E}-02$ & $9.83 \mathrm{E}-02$ \\
\hline E1160401101R4 & $\mathrm{Zn}-65$ & $-5.32 \mathrm{E}-02$ & $(\mathrm{U})$ & $3.41 \mathrm{E}-02$ & $9.68 \mathrm{E}-02$ \\
\hline E1160401201R4 & Ag-108M & $-6.81 \mathrm{E}-03$ & $(\mathrm{U})$ & $1.40 \mathrm{E}-02$ & 4.99E-02 \\
\hline E1160401201R4 & Ag-110M & $1.28 \mathrm{E}-02$ & $(\mathrm{U})$ & $1.57 \mathrm{E}-02$ & $5.24 \mathrm{E}-02$ \\
\hline E1160401201R4 & $\mathrm{Ce}-144$ & $-2.39 \mathrm{E}-02$ & (U) & $6.56 \mathrm{E}-02$ & $2.42 \mathrm{E}-01$ \\
\hline E1160401201R4 & Co-60 & $-5.74 \mathrm{E}-03$ & (U) & $1.39 \mathrm{E}-02$ & 5.03E-02 \\
\hline E1160401201R4 & Cs-134 & $2.75 \mathrm{E}-02$ & (U) & $1.91 \mathrm{E}-02$ & $6.47 \mathrm{E}-02$ \\
\hline E1160401201R4 & Cs-137 & $9.77 \mathrm{E}-01$ & & $6.46 \mathrm{E}-02$ & $5.16 \mathrm{E}-02$ \\
\hline E1160401201R4 & Eu-152 & $-1.53 \mathrm{E}-02$ & $(\mathrm{U})$ & $3.44 \mathrm{E}-02$ & $1.26 \mathrm{E}-01$ \\
\hline E1160401201R4 & Eu-154 & $-2.75 \mathrm{E}-02$ & $(\mathrm{U})$ & $4.97 \mathrm{E}-02$ & $1.77 \mathrm{E}-01$ \\
\hline E1160401201R4 & Eu-155 & $4.70 \mathrm{E}-02$ & (U) & $3.04 \mathrm{E}-02$ & $1.18 \mathrm{E}-01$ \\
\hline E1160401201R4 & Mn-54 & $-7.89 \mathrm{E}-03$ & $(\mathrm{U})$ & $1.43 \mathrm{E}-02$ & $5.10 \mathrm{E}-02$ \\
\hline E1160401201R4 & $\mathrm{Ru}-106$ & $1.77 \mathrm{E}-02$ & $(\mathrm{U})$ & $1.09 \mathrm{E}-01$ & 4.12E-01 \\
\hline E1160401201R4 & Sb-125 & $3.54 \mathrm{E}-02$ & (U) & $3.74 \mathrm{E}-02$ & $1.39 \mathrm{E}-01$ \\
\hline E1160401201R4 & $\mathrm{Zn}-65$ & $-5.84 \mathrm{E}-02$ & $(\mathrm{U})$ & 4.34E-02 & $1.27 \mathrm{E}-01$ \\
\hline E1160401301R4 & Ag-108M & $6.00 \mathrm{E}-03$ & $(\mathrm{U})$ & $1.33 \mathrm{E}-02$ & 4.84E-02 \\
\hline E1160401301R4 & Ag-110M & 8.33E-01 & (UJ) & 4.93E-02 & $1.12 \mathrm{E}-01$ \\
\hline E1160401301R4 & $\mathrm{Ce}-144$ & $-3.22 \mathrm{E}-02$ & $(\mathrm{U})$ & $6.93 \mathrm{E}-02$ & 2.63E-01 \\
\hline E1160401301R4 & Co-60 & $2.09 \mathrm{E}-02$ & (UJ) & $1.02 \mathrm{E}-02$ & $3.96 \mathrm{E}-02$ \\
\hline E1160401301R4 & Cs-134 & 4.87E-02 & (UJ) & $1.61 \mathrm{E}-02$ & $4.24 \mathrm{E}-02$ \\
\hline E1160401301R4 & Cs-137 & $6.92 \mathrm{E}+00$ & & $3.57 \mathrm{E}-01$ & $3.63 \mathrm{E}-02$ \\
\hline E1160401301R4 & Eu-152 & $-1.55 \mathrm{E}-03$ & $(\mathrm{U})$ & $3.34 \mathrm{E}-02$ & $1.24 \mathrm{E}-01$ \\
\hline E1160401301R4 & Eu-154 & $-1.23 \mathrm{E}-02$ & (U) & $3.13 \mathrm{E}-02$ & $1.12 \mathrm{E}-01$ \\
\hline E1160401301R4 & Eu-155 & $1.11 \mathrm{E}-01$ & (UJ) & $4.05 \mathrm{E}-02$ & $1.29 \mathrm{E}-01$ \\
\hline E1160401301R4 & Mn-54 & $1.17 \mathrm{E}-02$ & (U) & $9.95 \mathrm{E}-03$ & $3.71 \mathrm{E}-02$ \\
\hline E1160401301R4 & Ru-106 & $5.69 \mathrm{E}-02$ & (U) & $9.08 \mathrm{E}-02$ & $3.43 \mathrm{E}-01$ \\
\hline E1160401301R4 & $\mathrm{Sb}-125$ & $-1.97 \mathrm{E}-02$ & $(\mathrm{U})$ & $3.62 \mathrm{E}-02$ & $1.30 \mathrm{E}-01$ \\
\hline E1160401301R4 & $\mathrm{Zn}-65$ & $9.74 \mathrm{E}-02$ & $(\mathrm{UJ})$ & $2.83 \mathrm{E}-02$ & $1.00 \mathrm{E}-01$ \\
\hline E1160401401R4 & Ag-108M & $1.33 \mathrm{E}-02$ & $(\mathrm{U})$ & $1.45 \mathrm{E}-02$ & $5.46 \mathrm{E}-02$ \\
\hline
\end{tabular}


Table C-4. (continued).

\begin{tabular}{|c|c|c|c|c|c|}
\hline Sample ID & Radionuclide & $\begin{array}{c}\text { Sample Value } \\
(\mathrm{pCi} / \mathrm{g})\end{array}$ & $\begin{array}{c}\text { Validation } \\
\text { Flag }\end{array}$ & $\begin{array}{c}\text { Sample } \\
\text { Uncertainty } \\
(\mathrm{pCi} / \mathrm{g})\end{array}$ & $\begin{array}{l}\mathrm{MDA}^{\mathrm{a}} \\
(\mathrm{pCi} / \mathrm{g})\end{array}$ \\
\hline E1160401401R4 & Ag-110M & $3.09 \mathrm{E}-02$ & $(\mathrm{UJ})$ & $1.40 \mathrm{E}-02$ & $5.13 \mathrm{E}-02$ \\
\hline E1160401401R4 & $\mathrm{Ce}-144$ & $-3.22 \mathrm{E}-03$ & $(\mathrm{U})$ & $8.67 \mathrm{E}-02$ & $3.26 \mathrm{E}-01$ \\
\hline E1160401401R4 & Co-60 & $-2.35 \mathrm{E}-02$ & $(\mathrm{U})$ & $1.38 \mathrm{E}-02$ & $4.71 \mathrm{E}-02$ \\
\hline E1160401401R4 & Cs-134 & $9.15 \mathrm{E}-02$ & $(\mathrm{UJ})$ & $1.93 \mathrm{E}-02$ & $6.36 \mathrm{E}-02$ \\
\hline E1160401401R4 & Cs-137 & $1.26 \mathrm{E}+00$ & & $4.45 \mathrm{E}-02$ & $5.02 \mathrm{E}-02$ \\
\hline E1160401401R4 & Eu-152 & $-6.26 \mathrm{E}-04$ & $(\mathrm{U})$ & 4.12E-02 & $1.55 \mathrm{E}-01$ \\
\hline E1160401401R4 & Eu-154 & $-4.47 \mathrm{E}-02$ & (U) & $4.55 \mathrm{E}-02$ & $1.62 \mathrm{E}-01$ \\
\hline E1160401401R4 & Eu-155 & $7.85 \mathrm{E}-02$ & $(\mathrm{U})$ & $5.29 \mathrm{E}-02$ & $1.71 \mathrm{E}-01$ \\
\hline E1160401401R4 & $\mathrm{Mn}-54$ & $-2.16 \mathrm{E}-02$ & (U) & $1.41 \mathrm{E}-02$ & $4.88 \mathrm{E}-02$ \\
\hline E1160401401R4 & $\mathrm{Ru}-106$ & $8.61 \mathrm{E}-03$ & $(\mathrm{U})$ & $1.15 \mathrm{E}-01$ & 4.39E-01 \\
\hline E1160401401R4 & $\mathrm{Sb}-125$ & $-7.67 \mathrm{E}-04$ & $(\mathrm{U})$ & 4.01E-02 & $1.48 \mathrm{E}-01$ \\
\hline E1160401401R4 & $\mathrm{Zn}-65$ & $-4.93 \mathrm{E}-02$ & (U) & $3.92 \mathrm{E}-02$ & $1.11 \mathrm{E}-01$ \\
\hline E1160401501R4 & Ag-108M & $3.10 \mathrm{E}-03$ & $(\mathrm{U})$ & $2.14 \mathrm{E}-02$ & $7.82 \mathrm{E}-02$ \\
\hline E1160401501R4 & Ag-110M & $1.15 \mathrm{E}-01$ & (UJ) & $2.13 \mathrm{E}-02$ & 7.77E-02 \\
\hline E1160401501R4 & $\mathrm{Ce}-144$ & $-7.84 \mathrm{E}-02$ & $(\mathrm{U})$ & $9.90 \mathrm{E}-02$ & $3.63 \mathrm{E}-01$ \\
\hline E1160401501R4 & Co-60 & $2.37 \mathrm{E}-02$ & (U) & $1.40 \mathrm{E}-02$ & $5.57 \mathrm{E}-02$ \\
\hline E1160401501R4 & Cs-134 & $3.93 \mathrm{E}-02$ & (UJ) & $1.45 \mathrm{E}-02$ & $5.74 \mathrm{E}-02$ \\
\hline E1160401501R4 & Cs-137 & $1.30 \mathrm{E}+01$ & & $1.19 \mathrm{E}-01$ & $5.70 \mathrm{E}-02$ \\
\hline E1160401501R4 & Eu-152 & $4.90 \mathrm{E}-02$ & (U) & $5.48 \mathrm{E}-02$ & $2.07 \mathrm{E}-01$ \\
\hline E1160401501R4 & $\mathrm{Eu}-154$ & $6.77 \mathrm{E}-02$ & $(\mathrm{U})$ & $3.88 \mathrm{E}-02$ & $1.55 \mathrm{E}-01$ \\
\hline E1160401501R4 & Eu-155 & $-1.81 \mathrm{E}-02$ & (U) & $5.03 \mathrm{E}-02$ & $1.89 \mathrm{E}-01$ \\
\hline E1160401501R4 & Mn-54 & $2.82 \mathrm{E}-02$ & (UJ) & $1.31 \mathrm{E}-02$ & $4.23 \mathrm{E}-02$ \\
\hline E1160401501R4 & $\mathrm{Ru}-106$ & $-6.97 \mathrm{E}-02$ & $(\mathrm{U})$ & $1.66 \mathrm{E}-01$ & $5.13 \mathrm{E}-01$ \\
\hline E1160401501R4 & $\mathrm{Sb}-125$ & $1.70 \mathrm{E}-01$ & (UJ) & $7.96 \mathrm{E}-02$ & $2.29 \mathrm{E}-01$ \\
\hline E1160401501R4 & $\mathrm{Zn}-65$ & $2.52 \mathrm{E}-02$ & $(\mathrm{U})$ & $3.35 \mathrm{E}-02$ & $1.12 \mathrm{E}-01$ \\
\hline E1160400801RI & $\mathrm{I}-129$ & $-3.39 \mathrm{E}-01$ & $(\mathrm{U})$ & $1.92 \mathrm{E}-01$ & 4.14E-01 \\
\hline E1160400901RI & I-129 & $-2.02 \mathrm{E}-01$ & $(\mathrm{U})$ & $1.80 \mathrm{E}-01$ & 4.12E-01 \\
\hline E1160401001RI & I-129 & $-2.10 \mathrm{E}-03$ & $(\mathrm{U})$ & $1.72 \mathrm{E}-01$ & 4.33E-01 \\
\hline E1160401101RI & I-129 & $1.65 \mathrm{E}-01$ & $(\mathrm{U})$ & $2.01 \mathrm{E}-01$ & $3.77 \mathrm{E}-01$ \\
\hline E1160401201RI & I-129 & $-6.79 \mathrm{E}-02$ & (U) & $1.66 \mathrm{E}-01$ & $4.05 \mathrm{E}-01$ \\
\hline E1160401301RI & I-129 & $-1.54 \mathrm{E}-02$ & $(\mathrm{U})$ & $2.66 \mathrm{E}-01$ & $5.13 \mathrm{E}-01$ \\
\hline E1160401401RI & $\mathrm{I}-129$ & $2.47 \mathrm{E}-01$ & (U) & $2.03 \mathrm{E}-01$ & $4.55 \mathrm{E}-01$ \\
\hline E1160401501RI & I-129 & $3.02 \mathrm{E}-01$ & (U) & 2.91E-01 & 6.07E-01 \\
\hline \multicolumn{6}{|c|}{$\begin{array}{l}J=\text { analysis performed and radioactivity detected. Concentrations are less than the decision level and greater than the } \\
\text { minimum detectable concentration associated with the sample results. } \\
U \text { = nondetect. } \\
U J=\text { false positive due to concentrations less than the decision level and the minimum detectable concentration associated } \\
\text { with the sample result. } \\
\text { a. MDA = minimum detectable activity. }\end{array}$} \\
\hline
\end{tabular}


Table C-5. ESP-116-04 confirmatory sample results for mercury from Pond 1 on CPP-67.

\begin{tabular}{|c|c|c|c|}
\hline Sample ID & Analyte & $\begin{array}{c}\text { Sample Value } \\
(\mathrm{mg} / \mathrm{kg})\end{array}$ & Validation Flag \\
\hline E1160400001HG & Mercury & 0.28 & $(\mathrm{~J})$ \\
\hline E1160400101HG & Mercury & 1.4 & $(\mathrm{~J})$ \\
\hline E1160400201HG & Mercury & 0.47 & $(\mathrm{~J})$ \\
\hline E1160400301HG & Mercury & 0.36 & $(\mathrm{~J})$ \\
\hline E1160400401HG & Mercury & 1.3 & $(\mathrm{~J})$ \\
\hline E1160400501HG & Mercury & 0.075 & $(\mathrm{~J})$ \\
\hline E1160400502HG & Mercury & 0.07 & $(\mathrm{~J})$ \\
\hline E1160400601HG & Mercury & 0.43 & $(\mathrm{~J})$ \\
\hline E1160400701HG & Mercury & 0.33 & \\
\hline $\begin{array}{l}\mathrm{J}=\text { analysis performed and radioactivity detected. Concentrations are less than the decision level and greater than the } \\
\text { minimum detectable concentration associated with the sample results. }\end{array}$ & \multicolumn{2}{l}{} \\
\hline
\end{tabular}

Table C-6. Summary of the confirmation sampling results for Cs-137 in CPP-67, Pond 1.

\begin{tabular}{|c|c|c|c|c|c|}
\hline Sample ID & Radionuclide & $\begin{array}{l}\text { Sample Value }^{\mathrm{a}} \\
\text { (pCi/g) }\end{array}$ & $\begin{array}{l}\text { Validation } \\
\text { Flag }\end{array}$ & $\begin{array}{c}\text { Sample } \\
\text { Uncertainty } \\
(\mathrm{pCi} / \mathrm{g})\end{array}$ & $\begin{array}{l}\mathrm{MDA}^{\mathrm{b}} \\
(\mathrm{pCi} / \mathrm{g})\end{array}$ \\
\hline E1160400001R4 & Cesium-137 & 4.07E-01 & & $3.79 \mathrm{E}-02$ & $5.23 \mathrm{E}-02$ \\
\hline E1160400101R4 & Cesium-137 & $1.15 \mathrm{E}+00$ & & 7.74E-02 & $5.74 \mathrm{E}-02$ \\
\hline E1160400201R4 & Cesium-137 & $8.30 \mathrm{E}-01$ & & 4.92E-02 & 4.34E-02 \\
\hline E1160400301R4 & Cesium-137 & $2.89 \mathrm{E}-01$ & & $2.87 \mathrm{E}-02$ & $3.79 \mathrm{E}-02$ \\
\hline E1160400401R4 & Cesium-137 & $5.21 \mathrm{E}+00$ & & $2.55 \mathrm{E}-01$ & $5.18 \mathrm{E}-02$ \\
\hline E1160400501R4 & Cesium-137 & $3.37 \mathrm{E}-02$ & (UJ) & $1.48 \mathrm{E}-02$ & $5.76 \mathrm{E}-02$ \\
\hline E1160400601R4 & Cesium-137 & $2.40 \mathrm{E}-03$ & $(\mathrm{U})$ & $1.25 \mathrm{E}-02$ & 4.72E-02 \\
\hline E1160400701R4 & Cesium-137 & $5.00 \mathrm{E}+00$ & & $7.86 \mathrm{E}-02$ & $5.10 \mathrm{E}-02$ \\
\hline \multicolumn{6}{|c|}{ Summary Information } \\
\hline \multicolumn{3}{|c|}{ Maximum value } & 5.21 & & \\
\hline \multicolumn{3}{|c|}{ Average } & 1.62 & & \\
\hline \multicolumn{3}{|c|}{ Standard deviation } & 2.19 & & \\
\hline \multicolumn{3}{|c|}{ Confidence interval } & 1.52 & & \\
\hline \multicolumn{3}{|c|}{$95 \%$ upper confidence level } & 3.13 & & \\
\hline \multicolumn{6}{|c|}{$\begin{array}{l}\mathrm{U}=\text { nondetect. } \\
\mathrm{UJ}=\text { false positive due to concentrations less than the decision level and the minimum detectable concentration associated with the } \\
\text { sample result. }\end{array}$} \\
\hline \multicolumn{6}{|c|}{ a. Values consolidated from Table C-3. Calculations performed according to the description in Section 2.2.4. } \\
\hline
\end{tabular}


Table C-7. Summary of the confirmation sampling results for Cs-137 in CPP-67, Pond 2.

\begin{tabular}{|c|c|c|c|c|c|}
\hline Sample ID & Radionuclide & $\begin{array}{l}\text { Sample Value } \\
\text { (pCi/g) }\end{array}$ & $\begin{array}{l}\text { Validation } \\
\text { Flag }\end{array}$ & $\begin{array}{l}\text { Sample } \\
\text { Uncertainty } \\
(\mathrm{pCi} / \mathrm{g})\end{array}$ & $\begin{array}{l}\mathrm{MDA}^{\mathrm{b}} \\
(\mathrm{pCi} / \mathrm{g})\end{array}$ \\
\hline E1160400801R4 & Cesium-137 & $8.26 \mathrm{E}-01$ & & $6.24 \mathrm{E}-02$ & $5.47 \mathrm{E}-02$ \\
\hline E1160400901R4 & Cesium-137 & $1.33 \mathrm{E}-01$ & & $2.15 \mathrm{E}-02$ & 4.80E-02 \\
\hline E1160401001R4 & Cesium-137 & $1.99 \mathrm{E}-01$ & & $3.01 \mathrm{E}-02$ & $3.88 \mathrm{E}-02$ \\
\hline E1160401101R4 & Cesium-137 & $7.55 \mathrm{E}-02$ & $(\mathrm{~J})$ & $3.11 \mathrm{E}-02$ & 4.34E-02 \\
\hline E1160401201R4 & Cesium-137 & $9.77 \mathrm{E}-01$ & & $6.46 \mathrm{E}-02$ & $5.16 \mathrm{E}-02$ \\
\hline E1160401301R4 & Cesium-137 & $6.92 \mathrm{E}+00$ & & $3.57 \mathrm{E}-01$ & $3.63 \mathrm{E}-02$ \\
\hline E1160401401R4 & Cesium-137 & $1.26 \mathrm{E}+00$ & & 4.45E-02 & $5.02 \mathrm{E}-02$ \\
\hline E1160401501R4 & Cesium-137 & $1.30 \mathrm{E}+01$ & & 1.19E-01 & $5.70 \mathrm{E}-02$ \\
\hline \multicolumn{6}{|c|}{ Summary Information } \\
\hline \multicolumn{3}{|c|}{ Maximum value } & 13.00 & & \\
\hline \multicolumn{3}{|c|}{ Average } & 2.92 & & \\
\hline \multicolumn{3}{|c|}{ Standard deviation } & 4.66 & & \\
\hline \multicolumn{3}{|c|}{ Confidence interval } & 3.23 & & \\
\hline \multicolumn{3}{|c|}{$95 \%$ upper confidence level } & 6.15 & & \\
\hline \multicolumn{6}{|c|}{$\begin{array}{l}\mathrm{J}=\text { analysis performed and radioactivity detected. Concentrations are less than the decision level and greater than the minimum } \\
\text { detectable concentration associated with the sample results. } \\
\text { a. Values consolidated from Table C-4. Calculations performed according to the description in Section 2.2.4. } \\
\text { b. MDA = minimum detectable activity. }\end{array}$} \\
\hline
\end{tabular}


Appendix D

\section{High-Purity Germanium Data for CPP-67, East and West Ponds}




$$
\text { D-2 }
$$




\section{Appendix D}

\section{High-Purity Germanium Data for CPP-67, East and West Ponds}

Table D-1. CPP-67, east pond (Pond 1) high-purity germanium data.

\begin{tabular}{|c|c|c|c|}
\hline $\begin{array}{l}\text { Elevation }^{\mathrm{a}} \\
(\mathrm{ft} \text { amsl) }\end{array}$ & Sampling Point ID & $\begin{array}{l}\text { Cs-137 } \\
(\mathrm{pCi} / \mathrm{g})\end{array}$ & $\begin{array}{c} \pm 2 \text { Sigma } \\
(\mathrm{pCi} / \mathrm{g})\end{array}$ \\
\hline 4902.271 & ep1 & 1.5 & 0.1 \\
\hline 4900.166 & ep2 & 1.4 & 0.2 \\
\hline 4902.906 & ep3 & 1.8 & 0.1 \\
\hline 4900.145 & ep4 & 0.9 & 0.1 \\
\hline 4903.344 & ep5 & 0.9 & 0.1 \\
\hline 4904.881 & ep6 & 2.1 & 0.2 \\
\hline 4903.175 & ep7 & 1.1 & 0.1 \\
\hline 4904.141 & ep8 & 0.6 & 0.1 \\
\hline 4903.453 & ep9 & 0.5 & 0.1 \\
\hline 4904.215 & ep10 & 0.7 & 0.1 \\
\hline 4893.952 & ep11 & 0.7 & 0.1 \\
\hline 4899.522 & ep12 & 0.9 & 0.1 \\
\hline 4901.678 & ep13 & 4.8 & 0.1 \\
\hline 4902.471 & ep14 & 0.1 & 0.1 \\
\hline 4900.678 & ep15 & 0.5 & 0.1 \\
\hline 4899.512 & ep16 & 0.6 & 0.1 \\
\hline 4900.068 & ep17 & 0.8 & 0.1 \\
\hline 4902.216 & ep18 & 0.4 & 0.1 \\
\hline 4902.585 & ep19 & 0.4 & 0.1 \\
\hline 4905.543 & ep20 & 2.2 & 0.1 \\
\hline 4903.147 & ep21 & 1.6 & 0.1 \\
\hline 4906.862 & ep22 & 0.9 & 0.1 \\
\hline 4908.239 & ep-23 & 2.9 & 0.1 \\
\hline 4912.74 & ep-24 & 0.4 & 0.1 \\
\hline 4911.637 & ep-25 & 1 & 0.1 \\
\hline 4911.353 & ep-26 & 1 & 0.1 \\
\hline 4906.248 & ep-27 & 0.5 & 0.1 \\
\hline 4905.8 & ep-28 & 0.9 & 0.1 \\
\hline 4900.302 & ep29 & 1.6 & 0.1 \\
\hline 4903.379 & ep30 & 2.5 & 0.1 \\
\hline 4907.673 & ep31 & 0.7 & 0.2 \\
\hline 4907.842 & ep32 & 3.2 & 0.2 \\
\hline 4906.964 & ep33 & 3.1 & 0.2 \\
\hline 4904.664 & ep34 & 2.7 & 0.1 \\
\hline 4904.853 & ep35 & 2.6 & 0.2 \\
\hline 4903.169 & ep36 & 2.6 & 0.2 \\
\hline
\end{tabular}


Table D-1. (continued).

\begin{tabular}{|c|c|c|c|}
\hline $\begin{array}{l}\text { Elevation }^{\mathrm{a}} \\
(\mathrm{ft} \text { amsl) }\end{array}$ & Sampling Point ID & $\begin{array}{l}\text { Cs-137 } \\
\text { (pCi/g) }\end{array}$ & $\begin{array}{c} \pm 2 \text { Sigma } \\
(\mathrm{pCi} / \mathrm{g})\end{array}$ \\
\hline 4903.108 & ep37 & 4.1 & 0.1 \\
\hline 4903.797 & ep38 & 2.6 & 0.4 \\
\hline 4900.48 & ep39 & 0.6 & 0.2 \\
\hline 4908.524 & ep40 & 3.5 & 0.2 \\
\hline 4900.982 & ep41 & 0.5 & 0.1 \\
\hline 4901.881 & ep42 & 1 & 0.1 \\
\hline 4910.092 & ep43 & 2.1 & 0.2 \\
\hline 4912.443 & ep44 & 1.2 & 0.1 \\
\hline 4910.819 & ep45 & 1.8 & 0.4 \\
\hline 4916.505 & ep46 & 0.4 & 0.1 \\
\hline 4906.458 & ep47 & 3.5 & 0.1 \\
\hline 4908.301 & ep48 & 2.9 & 0.1 \\
\hline 4911.064 & ep49 & 2.1 & 0.1 \\
\hline 4909.515 & ep50 & 2.5 & 0.1 \\
\hline 4908.8 & ep51 & 0.9 & 0.1 \\
\hline 4908.861 & ep52 & 4.6 & 0.1 \\
\hline 4913.563 & ep53 & 6.3 & 0.1 \\
\hline 4918.863 & ep54 & 1.9 & 0.1 \\
\hline 4913.74 & ep55 & 0.9 & 0.1 \\
\hline 4913.771 & ep56 & 3.2 & 0.1 \\
\hline 4910.948 & ep58 & 1.4 & 0.1 \\
\hline 4912.759 & ep59 & 1.9 & 0.1 \\
\hline 4923.043 & ws1 & $-^{b}$ & - \\
\hline 4925.107 & ws2 & - & - \\
\hline 4922.357 & ws3 & - & - \\
\hline 4924.011 & ws4 & - & - \\
\hline 4924.547 & Ss1 & - & - \\
\hline 4923.162 & ss2 & - & - \\
\hline 4924.766 & ss 3 & - & - \\
\hline 4928.065 & ss4 & - & - \\
\hline 4923.537 & es1 & - & - \\
\hline 4920.802 & es2 & - & - \\
\hline 4920.513 & es3 & - & - \\
\hline 4920.852 & es4 & - & - \\
\hline 4925.171 & ns1 & - & - \\
\hline 4922.988 & ns2 & - & - \\
\hline 4919.737 & $\mathrm{~ns} 3$ & - & - \\
\hline 4920.737 & $\mathrm{~ns} 4$ & - & - \\
\hline
\end{tabular}


Table D-2. CPP-67, west pond (Pond 2) high-purity germanium data.

\begin{tabular}{|c|c|c|c|c|c|}
\hline $\begin{array}{c}\text { Elevation }^{\mathrm{a}} \\
(\mathrm{ft} \text { amsl) }\end{array}$ & $\begin{array}{l}\text { Sampling } \\
\text { Point ID }\end{array}$ & $\begin{array}{l}\mathrm{Cs}-137 \\
(\mathrm{pCi} / \mathrm{g}) \\
\end{array}$ & $\begin{array}{c} \pm 2 \text { Sigma } \\
(\mathrm{pCi} / \mathrm{g})\end{array}$ & $\begin{array}{c}\mathrm{K}-40 \\
(\mathrm{pCi} / \mathrm{g})\end{array}$ & $\begin{array}{c} \pm 2 \text { Sigma } \\
(\mathrm{pCi} / \mathrm{g})\end{array}$ \\
\hline 4902.625 & pp1 & 1.5 & 0.02 & 15 & 0.6 \\
\hline 4891.628 & pp2 & 0.3 & 0.03 & 14.5 & 0.6 \\
\hline 4900.891 & pp3 & 0.3 & 0.02 & 14.4 & 0.6 \\
\hline 4900.939 & pp4 & 0.4 & 0.05 & 15.1 & 0.5 \\
\hline 4901.727 & pp5 & 1.3 & 0.05 & 15 & 0.7 \\
\hline 4902.051 & pp6 & 0.2 & 0.03 & 15.5 & 0.8 \\
\hline 4902.468 & pp7 & 0.5 & 0.03 & 15.3 & 0.7 \\
\hline 4901.413 & pp8 & 0.2 & 0.03 & 14.7 & 0.7 \\
\hline 4897.971 & pp9 & 0.5 & 0.02 & 17.2 & 0.5 \\
\hline 4901.943 & pp10 & 0.7 & 0.05 & 14.4 & 0.6 \\
\hline 4899.058 & pp11 & 0.4 & 0.04 & 14.8 & 0.6 \\
\hline 4901.216 & pp12 & 0.4 & 0.03 & 15.6 & 0.8 \\
\hline 4898.663 & pp13 & 0.2 & 0.03 & 14.2 & 0.7 \\
\hline 4904.428 & pp14 & 0.3 & 0.04 & 14.5 & 0.5 \\
\hline 4907.986 & pp15 & 0.9 & 0.02 & 14.2 & 0.3 \\
\hline 4897.769 & pp16 & 1.3 & 0.02 & 14.3 & 0.4 \\
\hline 4899.537 & pp17 & 0.9 & 0.02 & 13.3 & 0.3 \\
\hline 4900.248 & pp18 & 1.4 & 0.02 & 16.4 & 0.2 \\
\hline 4912.4099 & pp19 & 2.3 & 0.1 & 9.2 & 0.3 \\
\hline 4912.2189 & pp20 & 5.1 & 0.1 & 9.6 & 0.3 \\
\hline 4911.4639 & pp21 & 5.5 & 0.1 & 9.5 & 0.3 \\
\hline 4910.5032 & pp22 & 4.4 & 0.1 & 10 & 0.3 \\
\hline 4910.928 & pp23 & 2.6 & 0.1 & 10.1 & 0.5 \\
\hline 4910.5096 & pp24 & 3.6 & 0.1 & 9.5 & 0.2 \\
\hline 4911.5364 & pp25 & 6.5 & 0.1 & 9.6 & 0.3 \\
\hline 4910.9102 & pp26 & 0.5 & 0.1 & 9.7 & 0.3 \\
\hline 4912.5878 & pp27 & 0.9 & 0.1 & 9.4 & 0.2 \\
\hline 4913.2422 & pp28 & 2.7 & 0.1 & 9.2 & 0.3 \\
\hline 4913.5812 & pp29 & 3.7 & 0.1 & 9.4 & 0.3 \\
\hline 4910.9848 & pp30 & 1.4 & 0.1 & 9.5 & 0.3 \\
\hline 4916.5103 & pp31 & 1.6 & 0.1 & 9.3 & 0.3 \\
\hline 4913.4224 & pp32 & 12.8 & 0.1 & 9.7 & 0.3 \\
\hline 4911.393 & pp33 & 9.2 & 0.1 & 9.1 & 0.3 \\
\hline 4913.6047 & pp34 & 2 & 0.1 & 9.6 & 0.4 \\
\hline 4913.756 & pp35 & 2.4 & 0.1 & 9.6 & 0.4 \\
\hline 4919.5704 & $\mathrm{n} 1$ & $-^{\mathrm{b}}$ & - & - & - \\
\hline 4921.3647 & $\mathrm{n} 2$ & - & - & - & - \\
\hline
\end{tabular}


Table D-2. (continued).

\begin{tabular}{|c|c|c|c|c|c|}
\hline $\begin{array}{c}\text { Elevation } \\
(\mathrm{ft} \text { amsl) }\end{array}$ & $\begin{array}{c}\text { Sampling } \\
\text { Point ID }\end{array}$ & $\begin{array}{c}\text { Cs-137 } \\
(\mathrm{pCi} / \mathrm{g})\end{array}$ & $\begin{array}{c} \pm 2 \text { Sigma } \\
(\mathrm{pCi} / \mathrm{g})\end{array}$ & $\begin{array}{c}\text { K-40 } \\
(\mathrm{pCi} / \mathrm{g})\end{array}$ & $\begin{array}{c} \pm 2 \text { Sigma } \\
(\mathrm{pCi} / \mathrm{g})\end{array}$ \\
\hline 4917.1918 & $\mathrm{n} 3$ & - & - & - & - \\
\hline 4919.7212 & $\mathrm{n} 4$ & - & - & - & - \\
\hline 4925.7114 & $\mathrm{w} 1$ & - & - & - & - \\
\hline 4925.0096 & $\mathrm{w} 2$ & - & - & - & - \\
\hline 4921.0534 & $\mathrm{w} 3$ & - & - & - & - \\
\hline 4922.2879 & $\mathrm{w} 4$ & - & - & - & - \\
\hline 4924.314 & $\mathrm{~s} 1$ & $\mathrm{~s} 2$ & - & - & - \\
\hline 4923.5307 & $\mathrm{~s} 3$ & $\mathrm{~s} 4$ & - & - & - \\
\hline 4922.8542 & $\mathrm{e} 1$ & - & - & - & - \\
\hline 4927.5939 & $\mathrm{e} 2$ & - & - & - & - \\
\hline 4926.409 & $\mathrm{e} 4$ & - & - & - & - \\
\hline
\end{tabular}


Appendix E

Gamma Scan Data for CPP-97: HPGe 
E-2 


\section{Appendix E}

\section{Gamma Scan Data for CPP-97: HPGe}

Table E-1. CPP-97 high-purity germanium data results.

\begin{tabular}{llcccc}
\hline Elevation & $\begin{array}{c}\text { Sampling } \\
\text { Point ID }\end{array}$ & $\begin{array}{c}\text { Cs-137 } \\
\text { (pCi/g) }\end{array}$ & $\begin{array}{c}2 \text { Sigma } \\
\text { (pCi/g) }\end{array}$ & $\begin{array}{c}\text { K-40 } \\
(\mathrm{pCi} / \mathrm{g})\end{array}$ & $\begin{array}{c}2 \text { Sigma } \\
\text { (pCi/g) }\end{array}$ \\
\hline 4873.598 & ge1 & $1.10 \mathrm{E}+00$ & $1.00 \mathrm{E}-01$ & $1.38 \mathrm{E}+01$ & $1.10 \mathrm{E}+00$ \\
4873.224 & ge2 & $4.40 \mathrm{E}+00$ & $2.00 \mathrm{E}-01$ & $1.34 \mathrm{E}+01$ & $9.00 \mathrm{E}-01$ \\
4871.688 & ge3 & $1.60 \mathrm{E}+00$ & $4.00 \mathrm{E}-01$ & $1.35 \mathrm{E}+01$ & $1.00 \mathrm{E}+00$ \\
4872.561 & ge4 & $3.00 \mathrm{E}+00$ & $2.00 \mathrm{E}-01$ & $1.39 \mathrm{E}+01$ & $1.10 \mathrm{E}+00$ \\
4871.198 & ge5 & $3.90 \mathrm{E}+00$ & $2.00 \mathrm{E}-01$ & $1.68 \mathrm{E}+01$ & $1.20 \mathrm{E}+00$ \\
4871.319 & ge6 & $2.50 \mathrm{E}+00$ & $1.00 \mathrm{E}-01$ & $1.63 \mathrm{E}+01$ & $1.10 \mathrm{E}+00$ \\
4869.016 & ge7 & $3.70 \mathrm{E}+00$ & $1.00 \mathrm{E}-01$ & $1.66 \mathrm{E}+01$ & $1.30 \mathrm{E}+00$ \\
4870.948 & ge8 & $1.60 \mathrm{E}+00$ & $2.00 \mathrm{E}-01$ & $1.74 \mathrm{E}+01$ & $1.20 \mathrm{E}+00$ \\
4871.094 & ge9 & $1.20 \mathrm{E}+00$ & $1.00 \mathrm{E}-01$ & $1.73 \mathrm{E}+01$ & $1.30 \mathrm{E}+00$ \\
4871.699 & ge10 & $4.00 \mathrm{E}+00$ & $1.00 \mathrm{E}-01$ & $1.37 \mathrm{E}+01$ & $7.00 \mathrm{E}-01$ \\
4873.391 & ge11 & $3.60 \mathrm{E}+00$ & $1.00 \mathrm{E}-01$ & $1.40 \mathrm{E}+01$ & $7.00 \mathrm{E}-01$ \\
4876.826 & ge12 & $2.10 \mathrm{E}+00$ & $1.00 \mathrm{E}-01$ & $1.41 \mathrm{E}+01$ & $7.00 \mathrm{E}-01$ \\
4875.768 & ge13 & $1.90 \mathrm{E}+00$ & $1.00 \mathrm{E}-01$ & $1.35 \mathrm{E}+01$ & $7.00 \mathrm{E}-01$ \\
4875.458 & ge14 & $1.90 \mathrm{E}+00$ & $1.00 \mathrm{E}-01$ & $1.42 \mathrm{E}+01$ & $7.00 \mathrm{E}-01$ \\
4876.488 & ge15 & $2.10 \mathrm{E}+00$ & $1.00 \mathrm{E}-01$ & $1.44 \mathrm{E}+01$ & $7.00 \mathrm{E}-01$ \\
4876.142 & ge16 & $1.00 \mathrm{E}-01$ & $1.00 \mathrm{E}-01$ & $1.73 \mathrm{E}+01$ & $1.30 \mathrm{E}+00$ \\
4875.807 & ge17 & $3.30 \mathrm{E}+00$ & $2.00 \mathrm{E}-01$ & $1.70 \mathrm{E}+01$ & $1.20 \mathrm{E}+00$ \\
4875.085 & ge18 & $6.50 \mathrm{E}+00$ & $3.00 \mathrm{E}-01$ & $1.67 \mathrm{E}+01$ & $1.20 \mathrm{E}+00$ \\
4869.8 & ge19 & $1.70 \mathrm{E}+00$ & $1.00 \mathrm{E}-01$ & $1.71 \mathrm{E}+01$ & $2.00 \mathrm{E}-01$ \\
4871.394 & ge20 & $1.00 \mathrm{E}+00$ & $1.00 \mathrm{E}-01$ & $1.40 \mathrm{E}+01$ & $6.00 \mathrm{E}-01$ \\
4872.482 & ge22 & $1.20 \mathrm{E}+00$ & $1.00 \mathrm{E}-01$ & $1.69 \mathrm{E}+01$ & $7.00 \mathrm{E}-01$ \\
4873.207 & ge21 & $1.60 \mathrm{E}+00$ & $8.00 \mathrm{E}-01$ & $1.45 \mathrm{E}+01$ & $3.00 \mathrm{E}-01$ \\
4872.306 & ge24 & $1.60 \mathrm{E}+00$ & $3.00 \mathrm{E}-01$ & $1.49 \mathrm{E}+01$ & $8.00 \mathrm{E}-01$ \\
4874.949 & ge23 & $1.40 \mathrm{E}+00$ & $2.00 \mathrm{E}-01$ & $1.67 \mathrm{E}+01$ & $4.00 \mathrm{E}-01$ \\
\hline
\end{tabular}

